UNIVERSIDADE DE SÃO PAULO

INSTITUTO DE GEOCIÊNCIAS

\title{
GEOLOGIA ESTRUTURAL DA ABA NORTE DA ESTRUTURA DIVERGENTE DO RIO PARAÍBA DO SUL: SEÇÕES TRÊS RIOS (RJ) - MATIAS BARBOSA (MG) E BARRA DO PIRAÍ - CONSERVATÓRIA (RJ)
}

Letícia Constantino Vicente

Orientador: Prof. Dr. Rômulo Machado

DISSERTAÇÃO DE MESTRADO

Programa de Pós-Graduação em Geoquímica e Geotectônica

SÃO PAULO

2008 


\section{ÍNDICE}

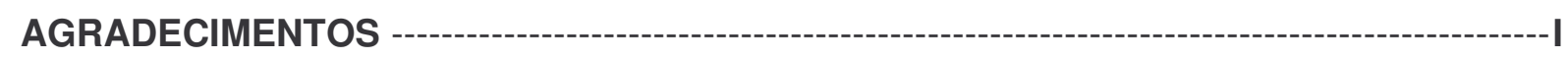

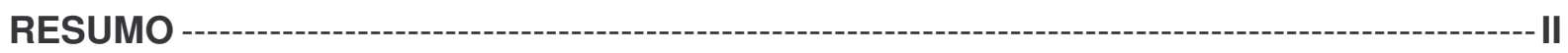

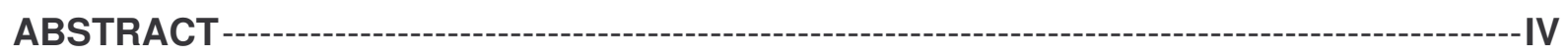

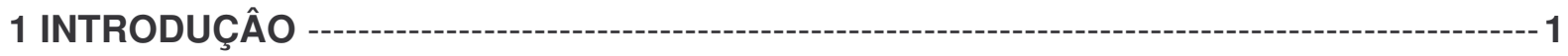

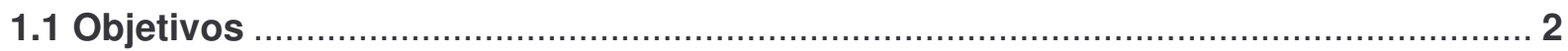

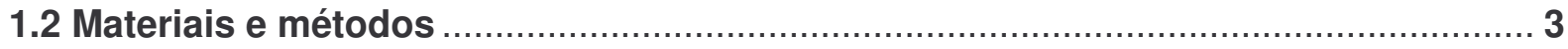

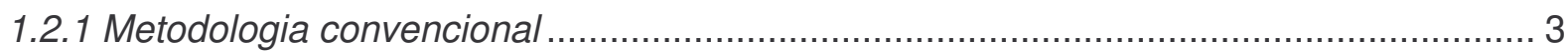

1.2.2 Metodologia específica - Electron backscattered diffraction (EBSD)........................... 4

1.3 Localização e acessos .............................................................................................. 5

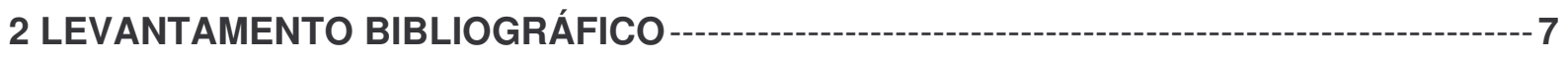

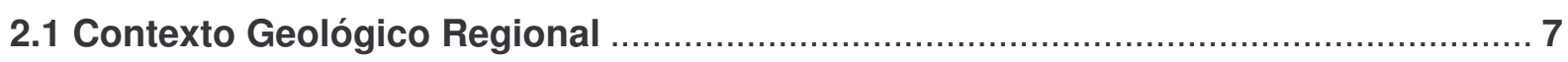

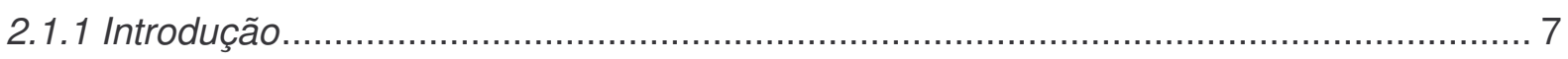

2.1.2 A Zona de Cisalhamento do Rio Paraíba do Sul........................................................ 11

2.2 Introdução ao conceito de transpressão e transtração ............................................. 15

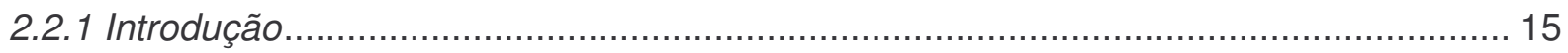

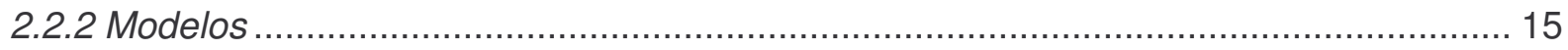

2.2.3 Elipsóides de deformação e apófises de fluxo .......................................................... 18

2.2.4 Estruturas lineares, planares e indicadores de movimento esperados ........................ 27

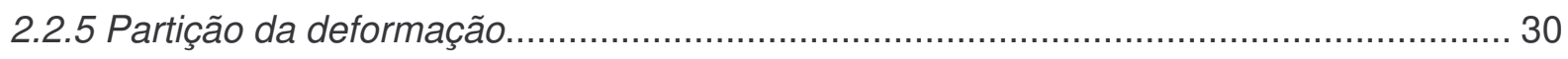

3 EXTRUSÃO TECTÔNICA E TRANSPORTE LATERAL DE MASSA NA PORÇÃO CENTRAL DO CINTURÃO PARAÍBA DO SUL, SEÇÃO TRÊS RIOS - MATIAS

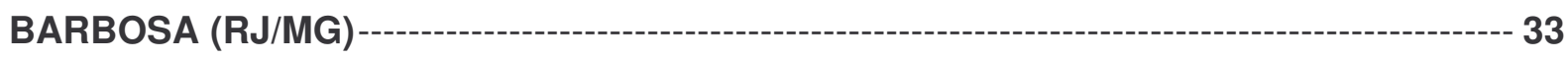

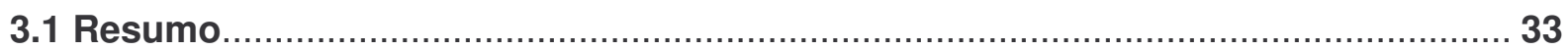

4 EXTRusÃo tectônica de GRANUlitos NA PORÇÃo CENTRAL dA PROVÍNCIA MANTIQUEIRA, SEÇÃO BARRA DO PIRAÍ - CONSERVATÓRIA, RJ. ------ 34

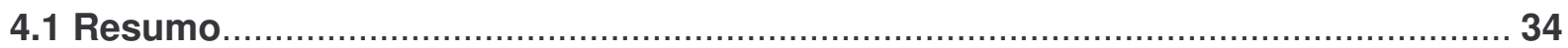

5 ORIENTAÇÃO PREFERENCIAL DE RETÍCULO CRISTALINO DO QUARTZO---------- 35

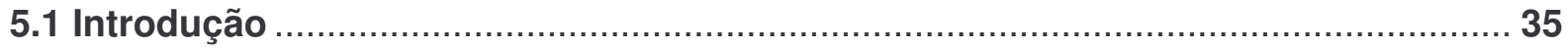

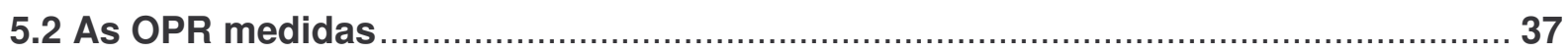


6 DISCUSSÃO

7 CONCLUSÕES

ANEXO I - EXTRUSÃO TECTÔNICA E TRANSPORTE LATERAL DE MASSA NA PORÇÃo CENTRAL dO CINTURÃO PARAíbA DO SUL, SEÇÃO TRÊS RIOS MATIAS BARBOSA (RJ/MG) - artigo publicado na Revista Brasileira de Geociências.

ANEXO II - EXTRUSÃO TECTÔNICA DE GRANULITOS NA PORÇÃO CENTRAL DA PROVÍNCIA MANTIQUEIRA, SEÇÃO BARRA DO PIRAÍ - CONSERVATÓRIA, RJ artigo submetido à Revista Brasileira de Geociências. 


\section{ÍNDICE DE FIGURAS E TABELAS}

Figura 1.1 - Figuras de difração geradas por meio da técnica de EBSD. a) Figura de difração de uma das amostras estudadas; b) formação das bandas de Kikuchi, devido à difração dos elétrons sobre os planos reticulares (extraído de Morales et al. 2007).

Figura 1.2 - Mapa de localização da área de estudo.

Figura 2.1 - Mapa Tectônico do segmento central da Província Mantiqueira. 1- Riftes Cenozóicos; 2- Rochas alcalinas do Cretáceo e Terciário; 3 e 4- Faixa Brasília (Nappes Inferiores e Superiores); 5, 6 e 7- Cráton São Francisco (Embasamento, Supergrupo São Francisco e Domínio Autóctone); 8 a 13 - Faixa Ribeira (Domínio Andrelândia, Domínio Juiz de Fora, Complexo Paraíba do Sul, Terreno Oriental, Granitóides do Complexo Rio Negro, Terreno Cabo Frio); 14 e 15- Faixa Apiaíl Paranapiacaba (Terrenos São Roque, Açungui e Embu) (extraído de Heilbron et al. 2004)......

Figura 2.2 - Mapa geológico da área de estudo, com a localização dos municípios que delimitam os perfis Schobbenhaus et al. (2004), Folha Rio de Janeiro (SF23).1- Depósitos colúvio-aluvionares; 2- Formação Resende; 3- Corpo Serra dos Tomazes; 4- Granito Arrozal; 5- Granito Vassouras; 6Suíte Varre-Sai; 7- Suíte Muriaé; 8- Granito Serra da Concórdia; 9- Granito Serra das Abóboras; 10 Suíte Serra das Araras; 11- Granito Rio Turvo; 12- Granitóide tipo-S sin-orogêncios; 13- Suíte Pouso Alto; 14- Complexo Embu, Unidade Paragnáissica; 15 e 16- Grupo Andrelândia (Migmatitos Alagoa e Unidade QuarTzítica); 17 e 18-Complexo Paraíba do Sul (Unidade Terrígena); 19- Suíte Quirino, 20 a 22- Complexo Juiz de Fora (Unidades Charnoquítica, Enderbítica e Tonalítica); 23Rios.

Tabela 2.1 - Dados geocronológicos recentes disponíveis para a área.

Figura 2.3 - Ilustração dos três extremos ("end-members da deformação") (Fossen et al. 1994). .... 15

Figura 2.4 - Modelos de transpressão assumindo volume constante: a - zona confinada nas laterais e na base, com encurtamento perpendicular compensado por estiramento vertical para cima; $b$ - transpressão não-confinada, onde a compressão é acomodada por extrusão lateral, para cima e para baixo; c - transtração não-confinada, onde a extensão é acomodada por afinamento vertical e encurtamento lateral (Jones et al. 1997).

Figura 2.5 - Relações entre os ângulos $\theta$ e a (ver texto) e o número de vorticidade cinemática $\left(W_{k}\right)$, e a mudança entre deformação dominada por cisalhamento puro e dominada por cisalhamento simples (Fossen et al. 1994).

Figura 2.6 - Diagrama mostrando a transpressão não-confinada separada em três componentes de deformação (cisalhamento puro em $X_{C} Y_{C}$, cisalhamento puro em $Y_{C} Z_{C}$ e cisalhamento simples em $\left.X_{c} Y_{c}\right)$ (Jones et al. 1997).

Figura 2.7 - Comparação entre os modelos de Sanderson \& Marchini (1984) (a), Robin \& Cruden (1994) (b) e Dutton (1997) (c) (extraído de Dutton, 1997). Os modelos b e c assumem não haver deslizamento de material nas margens da zona......

Figura 2.8 - Trajetória dos valores de $W_{k}$ em um diagrama de Flinn logarítmico. As linhas tracejadas correspondem à deformação dominada por cisalhamento simples, e as linhas cheias, por cisalhamento puro (Fossen et al. 1994).

Figura 2.9 - Modelo com as possíveis orientações do elipsóide de deformação finita em função dos componentes de cisalhamento simples e cisalhamento puro (extraído de Fossen et al. 1994).

Figura 2.10 - Tipos de transpressão e os eixos de deformação instantânea segundo Tikoff \& Teyssier (1994). Na transpressão dominada por cisalhamento puro, o componente de cisalhamento puro domina as deformações instantânea e finita. Na transpressão dominada por cisalhamento 
simples, o componente de cisalhamento puro, apesar de menor, é mais eficiente que o componente de cisalhamento simples na deformação finita.

Figura 2.11 - Relação entre os ângulos a (ângulo entre a apófise contracional do fluxo ou direção de máxima velocidade de convergência em regime transpressivo e a margem) e $\theta$ (ângulo entre $o$ eixo de deslocamento máximo instantâneo e a margem) (ver texto para explicação mais detalhada) (Tikoff \& Teyssier 1994).

Figura 2.12 - Esquema mostrando a geometria da deformação finita teórica para vários caminhos de deformação: a - bloco diagrama de uma zona de deformação inclinada com cisalhamento oblíquo, $b$ - geometria da deformação finita resultante, onde S representa os pólos da "foliação" ou $\lambda_{3}$, e L representa $\lambda_{1}$, ou "lineação" (Jiang et al. 2001).

Figura 2.13 - Diagramas de Flinn mostrando as possíveis geometrias do elipsóide de deformação finita para diferentes razões $R_{L v}$ : a - transpressão confinada; $b$ a e - relação crescente de estiramento lateral (Jones et al, 1997).

Figura 2.14 - Gráficos mostrando a orientação do maior eixo horizontal da deformação finita para vários valores de $R_{L V}$ (Jones et al, 1997).

Figura 2.15 - Comportamento da "foliação" e "lineação" para transpressão transcorrente destral no modelo de Robin \& Cruden (1994): a - bloco diagrama mostrando os traços da "foliação"; $b$ estereograma mostrando as mudanças na "lineação" (linhas cheias) e nos pólos da "foliação" (linhas tracejadas) através da zona......

Figura 2.16 - Fábricas e padrões cinemáticos previstos para duas relações de cisalhamento puro e cisalhamento simples em zonas transcorrentes destrais, considerando diferentes distâncias do centro da zona (Y) (Robin \& Cruden, 1994).

Figura 2.17 - Mapa de trajetória da "foliação" (linha cheia) e "lineação" (linha tracejada) para dois níveis horizontais, para transpressão oblíqua sinistral, com $\beta=75^{\circ}$. Projeções estereográficas mostram a relação entre o vetor vorticidade (quadrado), o plano perpendicular a ele (grande círculo tracejado), "foliação" (linha cheia) e "lineação" (círculo) (Robin \& Cruden, 1994)......

Figura 2.18 - Figura ilustrando a orientação de estruturas no modelo transpressivo. $C$ - eixo de compressão; $E$ - eixo de extensão; $N$ - falhas normais; $T$ - falhas de empurrão; $R$ e $R$ ' - falhas de Riedel; V - veios, diques e fraturas de extensão; $F$ - eixos de dobras (Sanderson \& Marchini 1984).. 27

Tabela 2.2 - Orientações de foliação e lineação de estiramento mineral esperadas para os tipos de transpressão e transtração descritos acima (Extraído de Fossen et al. 1994).

Figura 2.19 - Rotação de marcadores passivos para cisalhamento simples sinistral, envolvendo vários casos de transpressão e transtração, e cisalhamento puro; (a) - marcadores lineares, (b) marcadores planares (pólos dos planos) (Fossen et al. 1994).

Figura 2.20 - Esquema de vetores deslocamento mostrando o movimento relativo de partículas na zona de deformação adjacentes ao limite da zona. (a) - zona de deformação confinada na base e nas laterais, onde o movimento das partículas ocorre apenas para cima; (b) - zona de deformação não-confinada, onde ocorre extrusão lateral e espessamento vertical para cima e para baixo (Jones et al. 1997).

Figura 2.21 - Esquema de duas placas convergindo com um ângulo a, e o limite de placas caracterizado por deslocamento distribuído (a) e deslocamento particionado (b) (Tikoff \& Teyssier, 1994).......

Figura 5.1 - a) diagrama PxT de transformação de fases do $\mathrm{SiO}_{2}$; b) cristalografia do quartzo- $\alpha$ 
Figura 5.2 - a) diagrama de Flinn mostrando os padrões de distribuição de eixos $\langle c\rangle$ e $\langle a\rangle$ do quartzo para deformação progressiva coaxial. b) diagramas mostrando quatro tipos de orientação preferencial do retículo cristalino (OPR) de eixos $\langle c\rangle$ e $<a>$ do quartzo, desenvolvidas durante deformação progressiva não-coaxial (Passchier \& Trouw 1996).

Figura 5.3 - Imagem de relevo sombreado (Miranda \& Coutinho 2005) com a localização das amostras e Zona de Cisalhamento do Rio Paraíba do Sul.

Figura 5.4 - Diagramas de projeção estereográfica contendo os dados de foliação e lineação para as amostras nas quais foram medidas as orientações preferenciais da rede cristalográfica do quartzo..

Figura 5.5 - OPR do quartzo para a amostra STX 09 apresentada em figuras de pólo direta e inversa. Os contornos estão indicados ao lado das figuras, onde $N$ é o número de medidas. Para as figuras de pólo diretas, a foliação é vertical, E-W, e a lineação é horizontal, também E-W.

Figura 5.6 - Imagens SEM ("scanning electron microscope") das amostras analisadas. A e B) espécime STX 09; C) espécime STX 45; D) STX 245.

Figura 5.7 - Fotomicrografias das amostras estudadas. A e B - STX 09; C e D-STX 23; E e FSTX 45. 41

Figura 5.8 - OPR do quartzo para a amostra STX 23 apresentada em figuras de pólo diretas e inversas. As curvas de contorno estão indicadas ao lado das figuras, onde $N$ é o número de medidas. Para as figuras de pólo diretas, a foliação é vertical, E-W, e a lineação é horizontal, E-W. 43

Figura 5.9 - OPR do quartzo para a amostra STX 45 apresentada em figuras de pólo diretas e inversas. As curvas de contorno estão indicadas ao lado das figuras, onde $N$ é o número de medidas. Para as figuras de pólo diretas, a foliação é vertical, E-W, e a lineação é horizontal, E-W. 44

Figura 5.10 - Fotomicrografias das amostras estudadas. A e B - STX 245; C - STX 285; D - STX 287........

Figura 5.11 - OPR do quartzo para a amostra STX 245 apresentada em figuras de pólo diretas e inversas. As curvas de contorno estão indicadas ao lado das figuras, onde $N$ é o número de medidas. Para as figuras de pólo diretas, a foliação é vertical, E-W, e a lineação é horizontal, E-W. 46

Figura 5.12 - OPR do quartzo para a amostra STX 285 apresentada em figuras de pólo diretas e inversas. As curvas de contorno estão indicadas ao lado das figuras, onde $N$ é o número de medidas. Para as figuras de pólo diretas, a foliação é vertical, E-W, e a lineação é horizontal, E-W. 48

Figura 5.13 - OPR do quartzo para a amostra STX 45 apresentada em figuras de pólo diretas e inversas. As curvas de contorno estão indicadas ao lado das figuras, onde $N$ corresponde ao número de medidas. Para as figuras de pólo diretas, a foliação é vertical, E-W, e a lineação é horizontal, E-W. 


\section{AGRADECIMENTOS}

Agradeço em primeiro lugar a minha família pelo apoio, carinho e incentivo, não só durante a realização deste trabalho, mas durante toda minha formação.

Agradeço ao Prof. Dr. Rômulo Machado, pela atenção e disposição em me orientar e, sobretudo, pelas discussões que ajudaram na compreensão e construção de idéias em todas as etapas deste trabalho.

À CNPq pela concessão de uma bolsa de mestrado.

Agradeço aos companheiros de campo Nolan e Tiago (Pedrita), pelo auxílio e companhia durante os trabalhos de campo, além de valiosas discussões durante o tratamento dos dados e elaboração dos artigos.

Ao Prof. Dr. Leonardo Evangelista Lagoeiro, do Departamento de Geologia da Universidade Federal de Ouro Preto, pela possibilidade da realização de análises com o uso do EBSD, no Laboratório de Microscopia e Microanálise (MICROLAB). Não posso deixar de agradecer o pós-doutorando Luiz Fernando Grafulha Morales, pelo auxílio durante a preparação das amostras, as análises e também durante a interpretação.

Aos funcionários do Instituto de Geociências Ana Paula, Magali, Tadeu, Samuel, Angélica, o pessoal da laminação, Henrique, Seu Zé, Brenda, Érica, Dona Celina, e todos aqueles que de alguma forma tornaram mais fáceis as atividades desenvolvidas.

Aos amigos Samar Steiner e Carlos Grohmann (Guano) pelos socorros durante momentos de pane no PC, e Mariane Brumatti (Didi) pela ajuda na elaboração do "abstract". Aos amigos, que de alguma forma contribuíram para a realização deste trabalho, seja diretamente, ou apenas por proporcionarem momentos de descontração: Fernanda Quaglio, Adriana Alves (Bisteca), Carlos Conforti (Sfíncter), Lucas Warren (Falcon), Lígia, Jaqueline (Trans), Rodrigo (Traveco), Bruno (Melado), Fernando (Lampião), Renato (Lesma) e todos aqueles que estiveram presentes durante esses anos.

Expresso um agradecimento especial ao meu grande amigo e marido Luiz Fernando Roldan (Sagüi) pela força, paciência e carinho durante todo esse tempo.

Espero não ter havido nenhum esquecimento, mas agradeço sinceramente a todos aqueles que, de qualquer maneira, tenham contribuído para a realização desta dissertação. 


\section{RESUMO}

O presente trabalho trata da geologia estrutural de uma fração da Província Mantiqueira Central, correspondente no flanco norte da divergência em leque da calha do rio Paraíba do Sul. O levantamento de duas seções geológico-estruturais (seção Três Matias Matias Barbosa e seção Barra do Piraí - Conservatória) permitiu a caracterização das principais feições geométricas e cinemáticas na região. Além disso, a análise da orientação preferencial do retículo cristalino do quartzo em amostras coletadas ao longo dos perfis permitiu discutir os mecanismos de deformação e relacioná-los a um ambiente de crosta inferior.

Na seção Três Rios - Matias Barbosa foram reconhecidos três domínios estruturais distintos. Em todos eles a direção da foliação permanece orientada NE-SW, mas o ângulo de mergulho diminui à medida que se distancia da zona de cisalhamento, tornando-se uma foliação de baixo ângulo no domínio II, e de mergulho moderado no domínio III. A lineação mineral e de estiramento apresenta-se de caimento baixo nos domínios I e II, tornando-se oblíqua no domínio III, com caimento para NE. Em cada domínio observam-se, em escala de afloramento, estruturas geometricamente distintas. Os indicadores cinemáticos são compatíveis em ambos os domínios, mostrando movimentação destral em plano horizontal, e de topo para SW, nos planos de baixo ângulo.

Na seção Barra do Piraí - Conservatória, foram reconhecidos cinco domínios estruturais (I, II, III, IV e V). Os domínios I e V são caracterizados por uma foliação de alto ângulo na direção NE-SW e lineação direcional. Os domínios II, III e IV são caracterizados por uma foliação também na direção NE-SW, mas com o mergulho variando de baixo ângulo para NW, subvertical e baixo ângulo para SE, respectivamente. Os indicadores cinemáticos nos domínios I, III e V são coerentes com movimentação destral, mas não foram observados nos domínios II e IV. Da mesma forma como foi observado na seção Três Rios - Matias Barbosa, observa-se aqui, também, em escala de afloramento, intercalação de estruturas geometricamente distintas.

Os dados microestruturais e de orientação preferencial do retículo cristalino mostram variação na predominância de cisalhamento simples e cisalhamento puro nos diferentes domínios. Além disso, são registradas mudanças na ativação dos sistemas de deslizamento que podem estar relacionadas tanto com a existência de um gradiente termal durante a deformação ao longo das duas seções, como devida à manutenção de alta temperatura mesmo após a deformação, caracterizando o processo de "annealing". 
A mudança na geometria das estruturas pode ser caracterizada em termos da razão entre os componentes de cisalhamento simples e cisalhamento puro. Além disso, considerando-se as modelagens teóricas disponíveis, estas estruturas podem ser consideradas cinematicamente compatíveis em termos de um modelo de evolução tridimensional. Ambas as seções sugerem a existência de regiões resultantes da extrusão tectônica em regime transpressivo, correspondentes ao domínio II da seção Três Rios (RJ) Matias Barbosa (MG) e os domínios II, III e IV da seção Barra do Piraí - Conservatória (RJ). A mudança lateral e a relação de sobreposição das estruturas são interpretadas como resultantes da partição espacial e temporal da deformação. Assim, sugere-se que as estruturas nesse setor da Província Mantiqueira foram geradas em um regime de deformação transpressivo não-confinado em uma evolução tectônica simples. 


\section{ABSTRACT}

This study is about the structural geology of a portion of the Central Mantiqueira Province which corresponds to the north side of the structural divergence of the Rio Paraíba do Sul valley. Two geological cross-sections (Três Rios - Matias Barbosa and Barra do Piraí - Conservatória) provided geometrical and kinematics data. Lattice preferred orientation of quartz showed deformation mechanisms that affected these rocks in the lower crust.

Three distinct structural domains were recognized in the Três Rios - Matias Barbosa cross-section. They present NE-SW foliation with decreasing dip distant from the shear zone, low dip at domain II and moderate dip at domain III. The mineral and stretching lineation present low plunging at domains I and II and significant NE oblique dip at domain III. In all domains of the meso-scale there are observed distinct geometrically structures. Kinematics indicators are likely in all domains showing horizontal dextral sliding and top-to SW from low dip.

Five distinct domains were observed in the Barra do Piraí - Conservatória crosssection. Domains I and V are characterized by NE-SW steeply dipping foliation and strike lineation. Domains II, III and IV show NE-SW foliation presenting NW low dip, subvertical and SE low dip, respectively. Kinematics indicators at domains I, III and V show dextral shear sense, while in the domains II and IV, they were not observed. As in Três Rios - Matias Barbosa cross-section, meso-scale distinct geometrical structure intercalation were observed.

Microstructural data and lattice preferred orientation present variation in simple shear and pure shear for different domains. A change on the slip systems can be associated to thermal gradient along cross-section during deformation or to high temperature maintenance after deformation, characterizing an annealing process.

Changes on geometrical structures can be characterized as a relationship between simple shear and pure shear. Comparing these structures with theoretical modeling, we can consider them to be kinematics likely in a three-dimensional evolution model. Both crosssections suggest extrusion in transpressional tectonic pattern at domain II in Três Rios (RJ) Matias Barbosa (MG) cross-section and domains II, III and IV in Barra do Piraí Conservatória (RJ) cross-section. Lateral changes and structures overlapping are interpreted as a result of spatial and temporal partition of deformation. The presented data suggest that Mantiqueira Province structures in the studied area were generated by a non-confined transpressional deformation pattern in a simple tectonic evolution. 


\section{INTRODUÇÂO}

A Província Mantiqueira Central (ou Cinturão de Dobramentos Ribeira, Almeida et al. 1973) na região do Rio de Janeiro tem sido objeto de estudo de pesquisadores desde a metade do século passado, sendo os pioneiros Rosier (1957 e 1965), Ebert (1968), entre outros. Esta área se refere ao trecho da costa do Atlântico Sul afetado pelo Ciclo Brasiliano/Pan-Africano, correspondente a uma colisão oblíqua entre blocos crustais ocorrida durante a formação do supercontinente Gondwana Oeste (Almeida et al. 2000). Segundo os autores, esse evento é caracterizado por empurrões e nappes transportados para NW, presentes tanto nas porções internas do cinturão como mais para norte, em direção ao Craton do São Francisco.

Várias questões permanecem ainda pendentes a respeito da evolução tectônica da Província Mantiqueira Central. A partir de dados estruturais, petrológicos e geocronológicos, diferentes modelos tectônicos têm sido propostos para a região. Os primeiros modelos propostos consideram a evolução tectônica decomposta em vários episódios de deformação, onde as fases iniciais envolveriam encurtamento crustal em direção ao cráton do São Francisco, e a fase final seria relacionada ao desenvolvimento de grandes transcorrências destrais paralelas à orientação da faixa orogênica. Já os modelos evolutivos mais recentes sugerem um modelo tectônico mais simples, relacionado a um regime transpressivo, onde a contemporaneidade entre as estruturas compressivas e as transcorrentes implica numa articulação cinemática e partição da deformação sob condições de convergência oblíqua, envolvendo componentes de encurtamento transversal e de cisalhamento simples paralelos à estruturação geral. Esses diferentes modelos serão discutidos mais detalhadamente no decorrer deste trabalho.

Essa região da Província Mantiqueira é caracterizada por grandes zonas de cisalhamento que afloram por centenas de quilômetros. A maior delas é relacionada à Zona de Cisalhamento do Rio Paraíba do Sul (ou lineamento de Além-Paraíba), e encontra-se associada no Rio de Janeiro com rochas de alto grau, incluindo granulitos, em particular na parte norte do Estado. Caracteriza-se pela disposição divergente das estruturas em relação à zona central, coincidente com a calha do referido rio (Ebert 1968, Machado 1983, Machado \& Endo $1993 \mathrm{a}, \mathrm{b})$.

Nos modelos tectônicos polifásicos, propostos para explicar o arcabouço estrutural da região, esta estrutura é considerada de implantação tardia (Machado 1983, Heilbron 1993, Heilbron et al. 1991), e seu padrão divergente relacionado a uma estrutura sinclinorial com a zona de cisalhamento desenvolvida na zona de charneira. Já nos modelos de evolução 
tectônica simples, ela é interpretada como uma zona (ou sistema) de cisalhamento dúctil destral que acomoda um componente de contração normal ao orógeno em um regime transpressivo (Machado \& Endo 1993a, Dehler 2002).

A compreensão da evolução geológica neoproterozóica da Província Mantiqueira exige o uso de conhecimento gerado nas diferentes áreas das geociências, em especial as metodologias voltadas ao estudo do seu arcabouço tectônico. Assim, este trabalho trata especificamente da geologia estrutural (geométrica e cinemática), nas escalas meso e microscópica, de uma fração da Província Mantiqueira, correspondente a duas seções geológicas, ortogonais à estruturação regional, situadas no flanco norte da estrutura divergente da calha do Rio Paraíba do Sul, na porção noroeste do Estado do Rio de Janeiro e divisa com o Estado de Minas Gerais.

A dissertação está organizada em sete capítulos, sendo dois deles (Capítulos 3 e 4) correspondentes aos anexos I e II, publicado e submetido, respectivamente, à Revista Brasileira de Geociências. O anexo I trata da análise estrutural ao longo da seção Três Rios (RJ) - Matias Barbosa (MG), enquanto o anexo II se refere à análise geométrica e cinemática dos dados da seção Barra do Piraí - Conservatória, porção sudoeste do Estado do Rio de Janeiro.

No capítulo 5 são apresentados os dados microestruturais e de orientação preferencial de retículo cristalino do quartzo, a partir de rochas coletadas ao longo de ambas as seções. Esses dados mostram a ativação de processos em diferentes temperaturas, além de permitir uma discussão a respeito dos mecanismos de deformação atuantes na região. Os capítulos 6 e 7 apresentam as discussões e conclusões obtidas a partir dos dados apresentados nos capítulos anteriores.

\subsection{Objetivos}

O objetivo geral desse trabalho é contribuir para a elucidação do quadro de evolução estrutural no segmento central da Província Mantiqueira, porção ocidental do Estado do Rio de Janeiro.

Os objetivos mais específicos deste trabalho são:

- fornecer novos dados estruturais e cinemáticos no segmento estudado, além de caracterizar o arcabouço estrutural das principais zonas de cisalhamento e suas porções intermediárias; 
- avaliar e comparar os dados obtidos com as modelagens teóricas que descrevem convergência oblíqua de placas, considerando a análise tridimensional da deformação em regimes transpressivos;

- discutir os mecanismos de deformação envolvidos em ambiente de crosta inferior, assim como avaliar o regime deformacional (coaxial e não-coaxial) que essas rochas foram submetidas;

- comparar os resultados com os modelos estruturais/tectônicos regionais existentes;

- e, por fim, discutir a influência da Zona de Cisalhamento do Vale do Rio Paraíba do Sul nas regiões adjacentes.

\subsection{Materiais e métodos}

\subsubsection{Metodologia convencional}

A principal metodologia utilizada nesta pesquisa foi análise estrutural com base em dados levantados em trabalhos de campo, que se concentrou na realização de dois perfis geológicos transversais às estruturas regionais. A análise geométrica das estruturas constou da descrição da morfologia das estruturas em escala de afloramento. Em seguida, seguiu-se a metodologia proposta por Turner \& Weiss (1963), que consiste na delimitação de domínios homogêneos quanto à orientação de um determinado elemento estrutural. Após a delimitação desses domínios, procedeu-se a análise individual dos mesmos, onde os dados foram tratados estatisticamente em diagramas de projeção estereográfica Schmidt-Lambert, hemisfério inferior, no programa Stereonett 2.46.

$\mathrm{Na}$ análise cinemática procurou-se definir o sentido de rotação do fluxo deformacional, com base na assimetria de estruturas (porfiroclastos estirados e/ou rotacionados, boudins assimétricos, pares S-C de foliação, entre outros) no plano de máxima vorticidade, ou seja, o plano XZ do elipsóide de deformação finita. Vale, entretanto, lembrar que, no caso de deformação transpressiva, a lineação de estiramento pode marcar uma direção perpendicular ao movimento total (Fossen et al. 1994, Robin \& Cruden 1994), ou ainda o vetor de rotação pode não coincidir com nenhum eixo do elipsóide de deformação finita (Jiang et al. 2001).

Além da análise estrutural, foi feito também um levantamento da literatura nacional e internacional a respeito da evolução dos modelos tectônicos regionais, assim como da base teórica para os modelos de transpressão e transtração e análise dos mecanismos de deformação e padrões de orientações preferenciais da rede cristalina (OPR) do quartzo. Foi 
feito, ainda, o levantamento do material cartográfico básico para a realização dos trabalhos de campo.

\subsubsection{Metodologia específica - Electron backscattered diffraction (EBSD)}

Ao longo dos perfis foram coletadas amostras relativas aos diferentes domínios estruturais individualizados. As amostras foram orientadas segundo o plano XZ do elipsóide de deformação finita, utilizadas para a análise da OPR do quartzo.

As análises de OPR de grãos individuais de quartzo foram medidas empregando-se uma técnica que analisa a figuras de difração dos elétrons retroespalhados geradas em um microscópio eletrônico de varredura (MEV). A seguir é feita uma descrição sucinta a respeito dessa técnica, baseada no trabalho de Morales et al. (2007).

A técnica EBSD consiste na incidência de um feixe de elétrons em uma amostra com superfície perfeitamente plana, a um ângulo de incidência de $10^{\circ}$ a $30^{\circ}$ (inclinação da amostra de $60^{\circ}$ a $80^{\circ}$ com a horizontal). Quando o feixe interage com o material, uma fração dos elétrons não perde energia, apenas mudam de direção, e descrevem uma trajetória como se fossem emitidos por uma fonte pontual, situada no interior da amostra, em todas as direções. Esse "feixe divergente de elétrons" espalha-se coerentemente nos planos cristalinos e sofre o fenômeno de interferência denominado de difração. Esses feixes vão produzir os cones de Kossel, cuja intersecção com uma tela de fósforo produz as bandas de Kikuchi (figura 1.1). Então cada banda brilhante (banda de Kikuchi) resulta da difração dos elétrons em uma família de planos reticulares. Os ângulos entre as bandas de Kikuchi correspondem aos ângulos feitos pelas famílias de planos entre si, e a intersecção entre as bandas corresponde a direções cristalográficas.

A conversão das bandas de Kikuchi, detectadas na imagem de difração em vetores cristalográficos, é dada em ângulos de Euler, os quais descrevem o sistema de coordenadas da orientação do cristal em relação ao sistema de coordenadas na amostra. Na amostra, o sistema de coordenadas utilizado foi o plano de foliação e a lineação. O sistema de coordenadas do cristal é fixado pela rede cristalográfica.

As amostras foram cortadas em blocos de $\sim 1,5 \times 1,5 \times 0,7 \mathrm{~cm}$ e foram montadas em resina, sendo depois polidas mecanicamente com lixas de $45 \mu \mathrm{m}$ e $15 \mu \mathrm{m}$, respectivamente, e com pastas de diamante de 9, 3, 1 e 0,25 micrômetros. Depois disso, as amostras foram polidas em sílica coloidal durante $24 \mathrm{~h}$, para remover as irregularidades na superfície. 

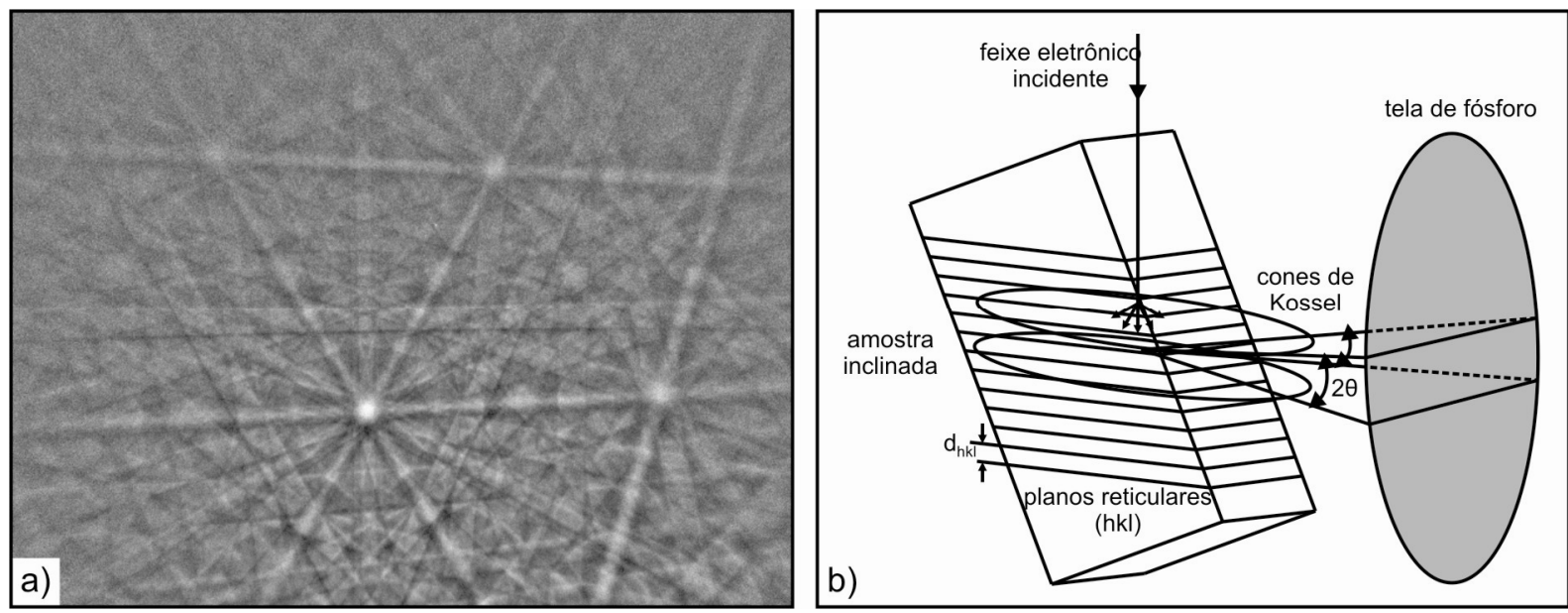

Figura 1.1 - Figuras de difração geradas por meio da técnica de EBSD. a) Figura de difração de uma das amostras estudadas; b) formação das bandas de Kikuchi, devido à difração dos elétrons sobre os planos reticulares (extraído de Morales et al. 2007).

A análise EBSD foi realizada no Laboratório de Microscopia e Microanálise (MICROLAB) do Departamento de geologia da Universidade Federal de Ouro Preto, usando um equipamento JEOL SEM JSM5510, equipado com detector Nordlys HKL-Oxford EBSD, operando com tensão de aceleração de $20 \mathrm{keV}$. As medidas foram feitas pelo modo "linescan", com a distância entre os pontos variando de acordo com a granulação da amostra. Estas foram colocadas com um ângulo de inclinação de 70ㅜ, e uma distância de trabalho de $35 \mathrm{~mm}$. A intensidade da corrente utilizada foi de $70 \mu \mathrm{A}$. O desvio angular utilizado para a aquisição dos dados (mean angular deviation - MAD) foi de $3^{\circ}$, e para 0 cálculo das figuras de pólo e figuras de pólo inversas variou de $0,7^{\circ}$ a 1,3ํㅡㄴ com 5 bandas utilizadas para a indexação. As figuras de pólo e as figuras de pólo inversas foram calculadas por meio dos programas PFch5 e IPFch5 (Mainprice, 2007).

\subsection{Localização e acessos}

A área estudada localiza-se na porção noroeste do Estado do Rio de Janeiro, e engloba duas seções geológicas transversais à estruturação regional: a primeira se estende da cidade de Três Rios, Rio de Janeiro, até o Estado de Minas Gerais, nas proximidades da cidade de Matias Barbosa, ao longo da Rodovia Washington Luís (BR-040), que liga as cidades do Rio de Janeiro e Belo Horizonte. A partir da cidade do Rio de Janeiro, o acesso pode ser feito, diretamente, seguindo-se pela Rodovia Washington Luís, na direção norte, passando pelas cidades de Duque de Caxias, Petrópolis, Areal, Três Rios, no vale do rio Paraíba do Sul, seguindo-se dali para a cidade de Matias Barbosa, MG. A partir da cidade de São Paulo, o acesso é feito pela Rodovia Presidente Dutra até a cidade de Volta 
Redonda, e seguindo-se daí pela Rodovia BR-393, que passa pelas cidades de Vassouras e Paraíba do Sul (figura 1.2).

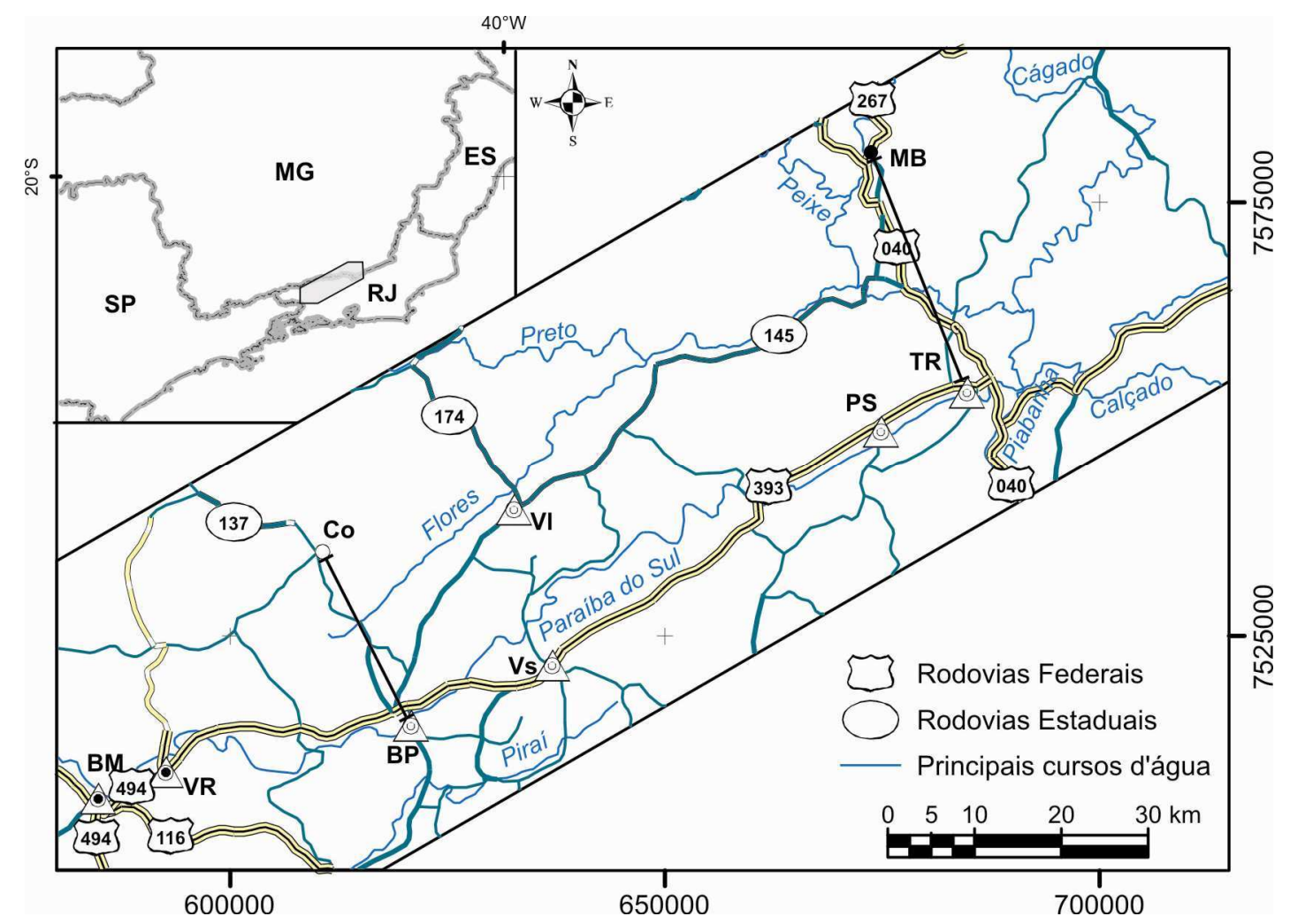

Figura 1.2 - Mapa de localização da área de estudo.

A segunda seção estende-se desde Barra do Piraí até as imediações de Conservatória, ambas no Estado do Rio de Janeiro, ao longo da rodovia RJ-137. A partir da cidade do Rio de Janeiro, o acesso pode ser feito pela Rodovia Presidente Dutra (BR-116) em direção a São Paulo, até a cidade de Piraí, seguindo-se pela rodovia RJ-145 até Barra do Piraí, onde se tem acesso à rodovia RJ-137. A partir da cidade de São Paulo, pode-se seguir pela Rodovia Presidente Dutra até a cidade de Volta Redonda, e seguindo-se daí pela Rodovia BR-393, que corta a rodovia RJ-137 nas proximidades de Barra do Piraí. 


\section{LEVANTAMENTO BIBLIOGRÁFICO}

\subsection{Contexto Geológico Regional}

\subsubsection{Introducão}

A área estudada situa-se no segmento central da Província Mantiqueira (Almeida et al. 1977, Almeida \& Hasui 1984), que se refere ao trecho da costa do Atlântico Sul afetado pelo Ciclo Brasiliano/Pan-Africano, que se estende desde o sul do Estado da Bahia até o Uruguai. Segundo a compartimentação tectônica deste segmento proposta por Heilbron et al (2004) (figura 2.1), as secções geológicas realizadas neste trabalho estão inseridas no Orógeno Ribeira, limite sudeste do Cráton São Francisco.

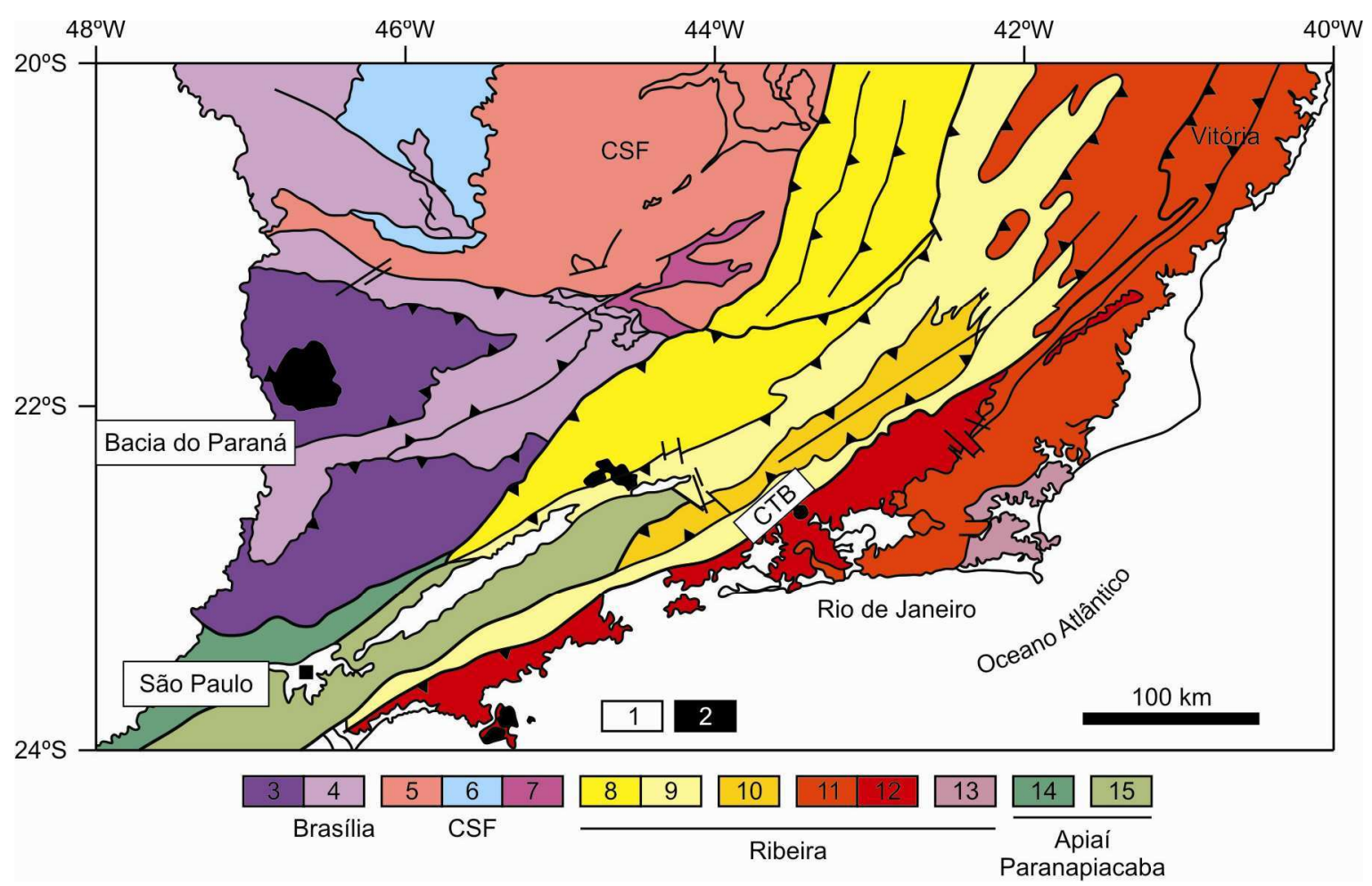

Figura 2.1 - Mapa Tectônico do segmento central da Província Mantiqueira. 1- Riftes Cenozóicos; 2Rochas alcalinas do Cretáceo e Terciário; 3 e 4- Faixa Brasília (Nappes Inferiores e Superiores); 5, 6 e 7- Cráton São Francisco (Embasamento, Supergrupo São Francisco e Domínio Autóctone); 8 a 13 Faixa Ribeira (Domínio Andrelândia, Domínio Juiz de Fora, Complexo Paraíba do Sul, Terreno Oriental, Granitóides do Complexo Rio Negro, Terreno Cabo Frio); 14 e 15- Faixa Apiaíl Paranapiacaba (Terrenos São Roque, Açungui e Embu) (extraído de Heilbron et al. 2004).

Os trabalhos disponíveis na literatura descrevem-no, de maneira geral, como resultado de uma colisão oblíqua entre blocos crustais ocorrida durante a formação do supercontinente Gondwana Oeste (Almeida et al. 2000). Considera-se que a colagem brasiliana $(0,9-0,5 \mathrm{Ga})$ nessa região foi marcada por empurrões em direção ao Cráton do 
São Francisco, sob condições metamórficas de pressão intermediária, e foi instalada sobre crosta arqueana, retrabalhada durante a Orogenia Transamazônica (2,1-1,9 Ga).

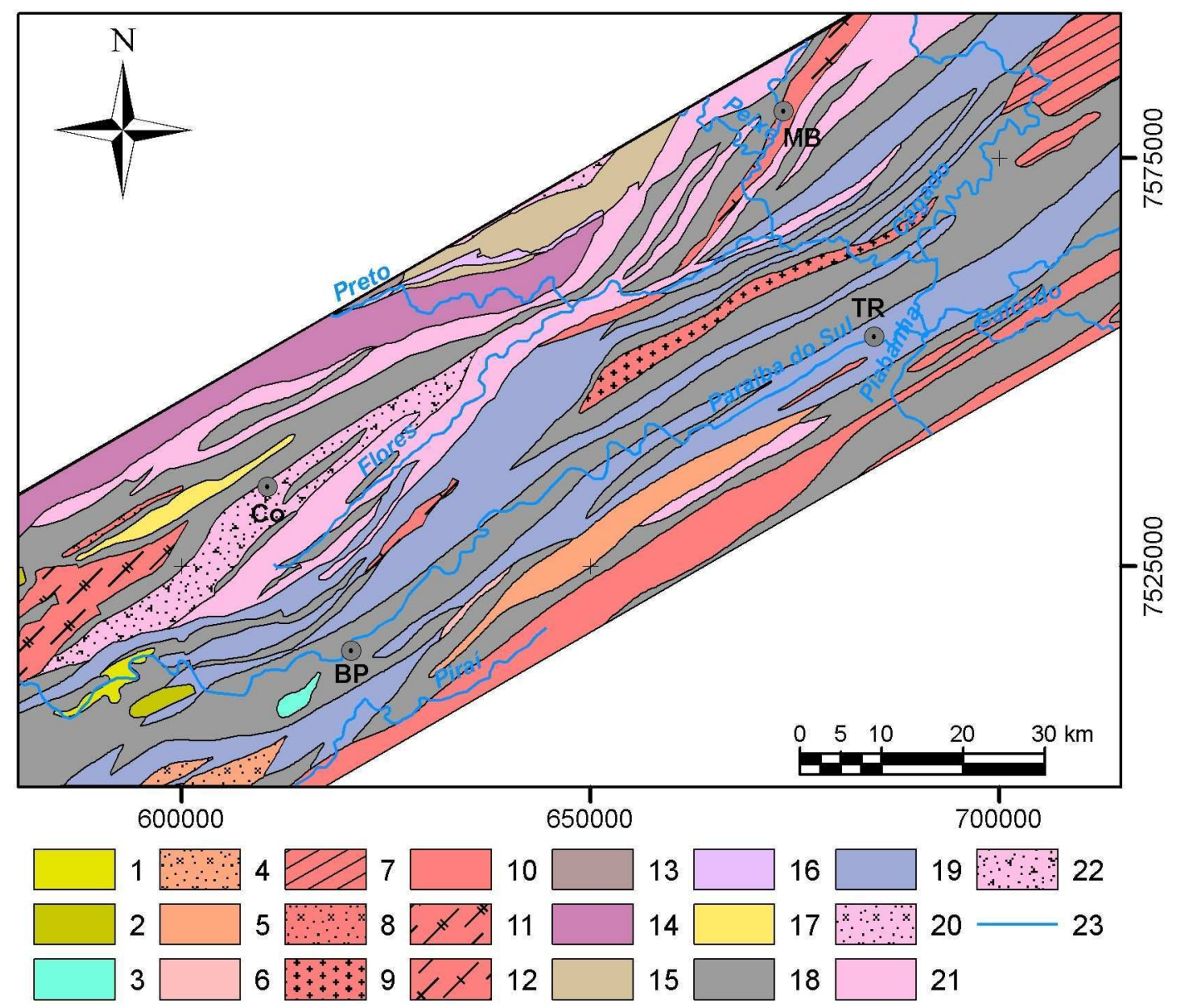

Figura 2.2 - Mapa geológico da área de estudo, com a localização dos municípios que delimitam os perfis Schobbenhaus et al. (2004), Folha Rio de Janeiro (SF23). 1- Depósitos colúvio-aluvionares; 2Formação Resende; 3- Corpo Serra dos Tomazes; 4- Granito Arrozal; 5- Granito Vassouras; 6- Suíte Varre-Sai; 7- Suíte Muriaé; 8- Granito Serra da Concórdia; 9- Granito Serra das Abóboras; 10- Suíte Serra das Araras; 11- Granito Rio Turvo; 12- Granitóide tipo-S sin-orogêncios; 13- Suíte Pouso Alto; 14- Complexo Embu, Unidade Paragnáissica; 15 e 16- Grupo Andrelândia (Migmatitos Alagoa e Unidade Quartzítica); 17 e 18- Complexo Paraíba do Sul (Unidade Terrígena); 19- Suíte Quirino, 20 a 22- Complexo Juiz de Fora (Unidades Charnoquítica, Enderbítica e Tonalítica); 23- Rios.

De acordo com a divisão tectônica de Heilbron et al (2004), o Orógeno Ribeira é dividido em cinco terrenos tectono-estratigráficos: (1) Ocidental (que compreende rochas dos domínios Autóctone, Andrelândia e Juiz de Fora), (2) Klippe Paraíba do Sul, (3) Embu, (4) Oriental e (5) Cabo Frio. Estes terrenos são considerados alóctones e sua justaposição seria o resultado do imbricamento de escamas crustais com vergência na direção oeste.

A região expõe rochas ígneas e metamórficas, de níveis crustais médios a profundos, paleo a neoproterozóicas, dispostas ao longo de zonas de cisalhamento de alto e baixo 
ângulo de direção NE-SW. Os diferentes litotipos encontrados na região podem ser agrupados em dois grandes grupos litoestruturais distintos: (1) rochas do embasamento, caracterizadas, de maneira geral, pelos ortogranulitos paleoproterozóicos do Complexo Juiz de Fora, freqüentemente migmatizadas; ortognaisses, também paleoproterozóicos do Complexo Quirino, considerado embasamento do Terreno Paraíba do Sul; e (2) cobertura metassedimentar neoproterozóica, formada pelo Domínio Andrelândia, que tem sido interpretada como uma bacia de margem passiva, e rochas do Terreno Paraíba do Sul, constituído por rochas metapelíticas e metapsamíticas, intercaladas com níveis carbonáticos e silico-carbonáticos (figura 2.2).

Os corpos graníticos encontrados na região podem ser divididos em pré a sincolisionais e tardi-colisionais. Os granitóides pré a sincolisionais são caracterizados por corpos lineares, foliados, concordantes com as estruturas regionais, constituídos principalmente por granitos peraluminosos, tipo-S, de composição essencialmente granítica a granodiorítica.

Os granitos tardi-colisionais são também concordantes com as estruturas das rochas encaixantes, e associam-se às zonas de cisalhamento de alto ângulo, possuindo composição monzogranítica dominante. Tais rochas teriam sido formadas em ambiente tectônico convergente, num período de exumação e anatexia de rochas metassedimentares. Uma síntese dos granitos neoproterozóicos da região pode ser encontrada em Machado \& Dehler (2002) (ver também Machado et al. 2006 e Nummer et al. 2007).

Entre os modelos estruturais existentes para a região, destaca-se o modelo polifásico (Machado 1983 e 1984, Heilbron 1993, Heilbron et al. 1995 e 1998), onde o arcabouço final da deformação teria sido dado, primeiramente, por duas fases de deformação iniciais contínuas, responsáveis pelo desenvolvimento da foliação e bandamento regional, dobras isoclinais assimétricas, empurrões direcionados para NW, em regime de deformação coaxial. Essa fase é considerada concomitante com metamorfismo M1, em fácies granulito. As estruturas aqui geradas foram sobrepostas por uma terceira fase, caracterizada por dobras abertas a fechadas e zonas de cisalhamento de alto ângulo, com movimentação destral, que desenvolveram localmente foliação milonítica e estruturas de cisalhamento como mullions e tectonitos-L. Essas zonas de cisalhamento seriam responsáveis pela estruturação geral NE-SW do cinturão, e teriam ocorrido sob condições de metamorfismo em fácies anfibolito superior. Os autores descrevem ainda uma quarta fase de deformação, responsável principalmente pela geração de dobras de perfis abertos, cuja orientação axial dispõe-se de forma ortogonal à orientação geral das estruturas acima descritas. Tais estruturas são difíceis de ser reconhecidas em escala de afloramento. 
Este modelo evoluiu para um modelo de duas fases de deformação, mantendo-se, no entanto, a proposta de uma vergência tectônica inicial para NW, seguida por uma tectônica transcorrente que teria sido acomodada em zonas de cisalhamento (Almeida, 2000, Peternel et al. 2005). Nestes trabalhos são descritos, além dos empurrões para NW, movimentos oblíquos registrados por lineações de estiramento e mineral de rake moderado. Segundo Almeida (2000), existe uma defasagem de $30 \mathrm{Ma}$ entre os dois regimes.

Outros modelos existentes assumem uma colisão oblíqua E-W, resultando em um ambiente de deformação transpressiva (Ebert et al. 1991 e 1993, Ebert \& Hasui 1998, Ebert, 2005, Dehler 2002, Dehler \& Machado 2002). Neste modelo, o progressivo encurtamento e espessamento da crosta, em deformação predominantemente compressiva, fazem com que os cavalgamentos (direcionais e tangenciais) ao longo de zonas de cisalhamento dúcteis de baixo ângulo sejam substituídos por deformação acomodada principalmente em zonas de cisalhamento transcorrentes de alto ângulo paralelas à estruturação geral do cinturão. Desse modo, tal modelo descreve dois estágios de deformação progressiva contínua, causada por colisão oblíqua de placas, que resultou em uma geometria transpressiva no estágio finito de deformação.

Os autores descrevem uma alternância entre as regiões com predomínio de contração e transcorrência, como resultado da partição regional da deformação. O reconhecimento de estruturas tipicamente compressivas, como estiramentos verticais juntamente com estruturas de cisalhamento, estruturas em flor positivas em escala de afloramento, assim como dados de microestruturas (Egydio-Silva et al. 2005), sugerem que os dois regimes de deformação coexistiram em várias escalas, e, sendo assim, a partição não teria ocorrido em nível regional. Em função dessas características, alguns autores têm sugerido que, embora o ambiente deformacional tenha sido transpressivo, a evolução tectônica foi relativamente simples (Correa Neto et al. 1993). Essa evolução tectônica teria ocorrido sob condições metamórficas em fácies granulito e acompanhada de metamorfismo retrógrado na fácies anfibolito superior.

Os dados geocronológicos mais recentes disponíveis para a região estão sintetizados na tabela 2.1. As referentes unidades tectono-estratigráficas estão de acordo com o proposto pelos autores.

Pode-se observar que, de maneira geral, existe uma tendência em considerar os pulsos metamórficos M1 e M2 (Machado, 1983 e 1984, Heilbron, 1993, Heilbron et al, 1995 e 1998) de idades entre 591 - 563 Ma e 535 - 503 Ma, respectivamente. As idades intermediárias, segundo alguns autores, seriam indícios de que esses eventos metamórficos 
foram contínuos. Rochas consideradas do embasamento nos domínios Juiz de Fora e Paraíba do Sul foram formadas principalmente durante a Orogenia Transamazônica, havendo evidências de algum componente Arqueano.

\subsubsection{A Zona de Cisalhamento do Rio Paraíba do Sul}

O Cinturão Ribeira é marcado por uma série de zonas de cisalhamento verticais, de direção NE-SW, apresentando em geral movimentação destral. A Zona de Cisalhamento do Rio Paraíba do Sul é uma grande estrutura nesse contexto, caracterizada pela disposição divergente das estruturas em relação à zona central, coincidente com a calha do rio em questão (Ebert 1968).

Essa estrutura é formada pelo sistema de lineamentos Além Paraíba-CubatãoLancinha. O principal deles, o lineamento Além-Paraíba, estende-se no Estado do Rio de Janeiro por aproximadamente $240 \mathrm{~km}$, e é formado, na sua região central, por rochas blastomiloníticas (Almeida et al. 1975, Campanha 1980 e 1981). Sadowski (1983) sugere para este lineamento um deslocamento mínimo de $40 \mathrm{~km}$.

No modelo polifásico de deformação regional (Machado 1983 e 1984), a estrutura do vale do rio Paraíba do Sul é considerada como uma estrutura sinclinorial relacionada à terceira fase de dobramento. Esta mesma estrutura tem sido denominada também Megassinforma do Rio Paraíba do Sul, caracterizada por uma zona de cisalhamento em sua zona de charneira (Heilbron et al, 1991 e 1995, Heilbron, 1993).

A divergência característica, onde as estruturas a NW do vale do Rio Paraíba do Sul mergulham para SE, e as estruturas a SE mergulham para NW, sendo verticais na sua porção central, levaram alguns autores (Machado \& Endo 1993b, Ebert et al. 1993b, Ebert et al. 1995, Correa neto et al. 1993) a descrever a zona de cisalhamento como integrante da parte central de uma estrutura em flor positiva, resultante da deformação em um ambiente transpressivo (Dayan \& Keller 1990, Machado \& Endo 1993a).

Egydio-Silva (1996) sugere que essas zonas de cisalhamento destrais no cinturão estão relacionadas ao escape tectônico da litosfera em direção a SW, na terminação de um bloco rígido durante uma colisão continental, de acordo com o modelo de Vauchez et al. (1994).

Dehler \& Machado (2002) e Dehler (2002), num estudo realizado na aba sul da estrutura, referem-se à mesma como uma divergência em leque, associada principalmente 
com o segundo estágio de deformação contínua de caráter transpressivo (ver também Karniol et al 2008). 
Tabela 2.1 - Dados geocronológicos recentes disponíveis para a área.

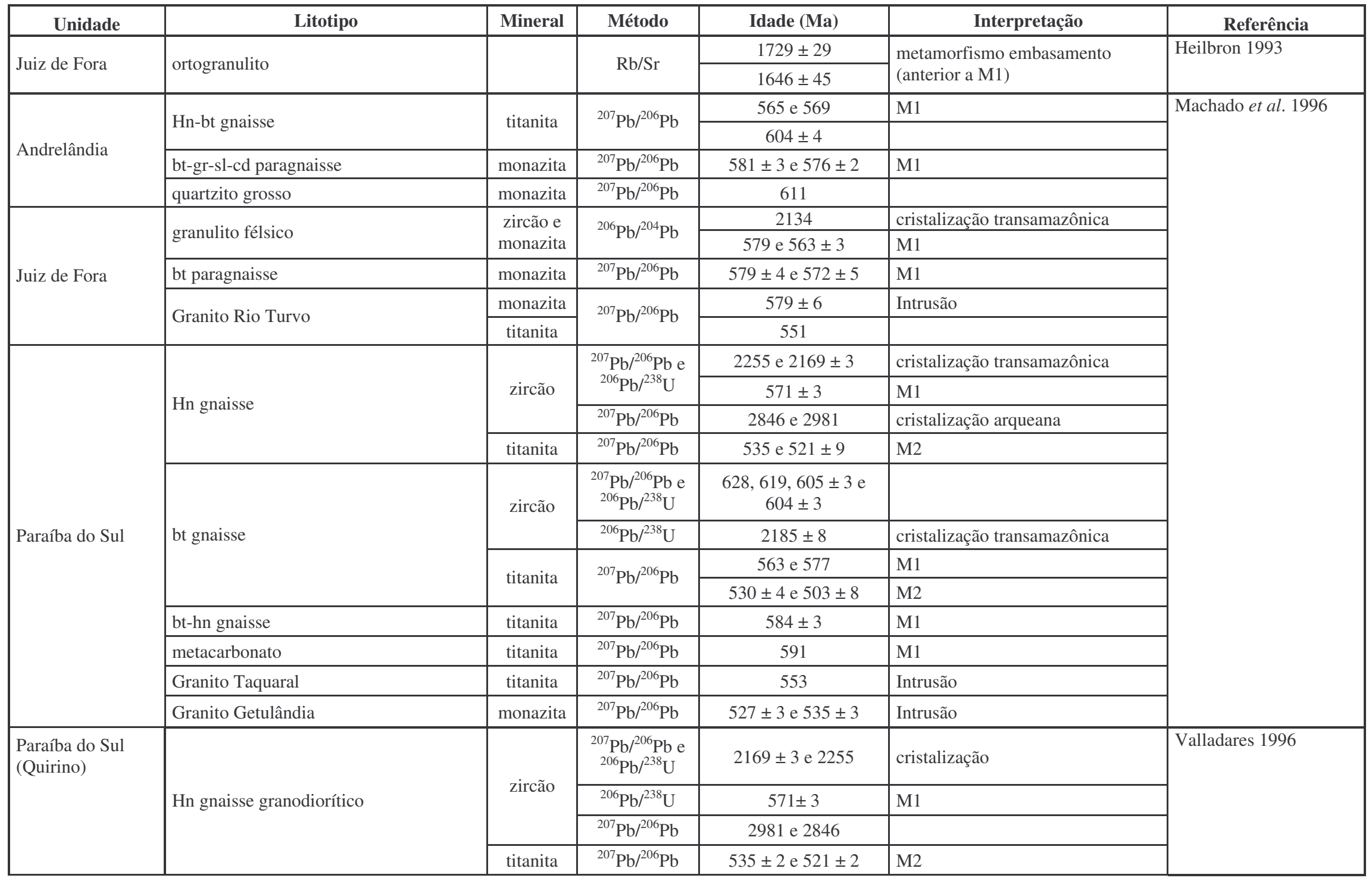




\begin{tabular}{|c|c|c|c|c|c|c|}
\hline & \multirow{6}{*}{ Bt gnaisse granítico } & \multirow{3}{*}{ zircão } & \multirow{2}{*}{${ }^{206} \mathrm{~Pb} /{ }^{238} \mathrm{U}$} & $605 \pm 3$ & início M1 & \\
\hline & & & & $2185 \pm 8$ & cristalização & \\
\hline & & & ${ }^{207} \mathrm{~Pb} /{ }^{206} \mathrm{~Pb}$ & 619 e 628 & & \\
\hline & & \multirow{3}{*}{ titanita } & \multirow{2}{*}{${ }^{207} \mathrm{~Pb} /{ }^{206} \mathrm{~Pb}$} & 577,563 e $584 \pm 2$ & M1 & \\
\hline & & & & $530 \pm 2$ & M2 & \\
\hline & & & ${ }^{206} \mathrm{~Pb} /{ }^{238} \mathrm{U}$ & $503 \pm 2$ & & \\
\hline Paraíba do Sul & calciossilicática & titanita & ${ }^{207} \mathrm{~Pb} /{ }^{206} \mathrm{~Pb}$ & 590 & M1 & \\
\hline \multirow{2}{*}{ Juiz de Fora } & \multirow{2}{*}{ Granitóide Rio Turvo } & monazita & ${ }^{207} \mathrm{~Pb} /{ }^{206} \mathrm{~Pb}$ & $579 \pm 2$ & cristalização sin D1+D2 & \\
\hline & & titanita & ${ }^{207} \mathrm{~Pb} /{ }^{206} \mathrm{~Pb}$ & 551 & continuidade entre M1 e M2 & \\
\hline \multirow{3}{*}{ Paraíba do Sul } & Granito Taquaral & titanita & ${ }^{207} \mathrm{~Pb} /{ }^{206} \mathrm{~Pb}$ & 553 & continuidade entre M1 e M2 & \\
\hline & \multirow{2}{*}{ Granito Getulândia } & \multirow{2}{*}{ monazita } & ${ }^{207} \mathrm{~Pb} /{ }^{206} \mathrm{~Pb}$ & $528 \pm 1$ & cristalização $\sin \mathrm{D} 3$ & \\
\hline & & & ${ }^{207} \mathrm{~Pb} /{ }^{206} \mathrm{~Pb}$ & $535 \pm 1$ & M2 & \\
\hline \multirow{2}{*}{ Andrelândia } & \multirow{2}{*}{ metaquartzito grosso } & \multirow{2}{*}{ zircão } & \multirow{2}{*}{${ }^{207} \mathrm{~Pb} /{ }^{206} \mathrm{~Pb}$} & 2100 a 2200 & \multirow{5}{*}{$\begin{array}{l}\text { Área fonte relacionada com a } \\
\text { crosta transamazônica e arqueana } \\
\text { subordinada }\end{array}$} & \multirow[t]{5}{*}{ Valladares et al. 1997} \\
\hline & & & & 2700 a 2800 & & \\
\hline \multirow{3}{*}{ Juiz de Fora } & bt paragnaisse & zircão & ${ }^{207} \mathrm{~Pb} /{ }^{206} \mathrm{~Pb}$ & 2000 a 2100 & & \\
\hline & \multirow{2}{*}{ quartzito grosso } & \multirow{2}{*}{ zircão } & \multirow{2}{*}{${ }^{207} \mathrm{~Pb} /{ }^{206} \mathrm{~Pb}$} & 2000 a 2200 & & \\
\hline & & & & 2605 a 2763 & & \\
\hline \multirow{2}{*}{ Andrelândia } & Ortognaisse granítico & \multirow{5}{*}{-} & \multirow{5}{*}{$\mathrm{Sm} / \mathrm{Nd}$} & 2453 & cristalização & \multirow[t]{5}{*}{ Ragatky et al, 1999} \\
\hline & Ortognaisse granodiorítico & & & 2614 & cristalização & \\
\hline Juiz de Fora & Granulito básico & & & 2143 & cristalização & \\
\hline \multirow{2}{*}{ Paraíba do Sul } & Ortognaisse granítico & & & 2213 & cristalização & \\
\hline & Ortognaisse granodiorítico & & & 2695 & cristalização & \\
\hline Andrelândia & metapelitos & \multirow{4}{*}{-} & \multirow{4}{*}{$\mathrm{Sm} / \mathrm{Nd}$} & 1800 a 2500 & $\begin{array}{l}\text { Área fonte } \rightarrow \text { C. Mantiqueira e } \\
\text { Juiz de Fora }\end{array}$ & \multirow[t]{4}{*}{ Ragatky et al, 2000} \\
\hline \multirow{3}{*}{ Paraíba do Sul } & metapsamopelitos (unidade superior) & & & 2000 & & \\
\hline & metapelitos (unidade intermediária) & & & 1700 & Área fonte $\rightarrow$ C.Quirino & \\
\hline & metapsamopelitos (unidade inferior) & & & 2000 & & \\
\hline
\end{tabular}




\subsection{Introdução ao conceito de transpressão e transtração}

\subsubsection{Introdução}

Os termos transpressão e transtração, introduzidos por Harland (1971), referem-se, de maneira geral, a regimes tectônicos caracterizados por situações intermediárias a convergência/divergência e transcorrência puras, gerados por interação oblíqua entre margens de placas. Essa relação vem sendo observada em orógenos atuais (falhas Great Sumatran, San Andréas, Alpina, entre outras) e tornou-se uma hipótese conveniente para explicar o arcabouço e a evolução de orógenos antigos, onde a complexidade das estruturas dificilmente pode ser explicada pela atuação apenas de um regime tectônico simples (ver figura 2.3).

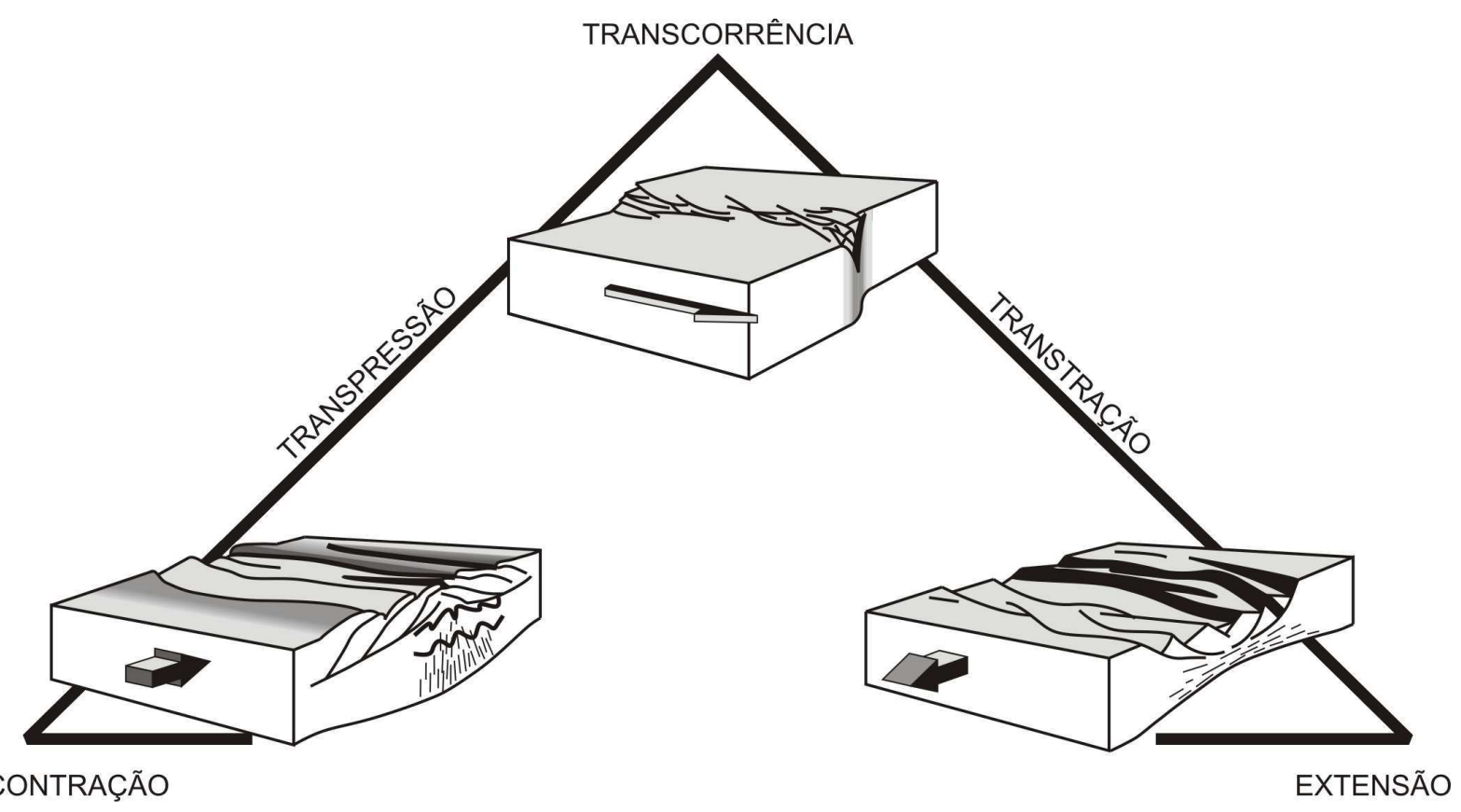

Figura 2.3 - Ilustração dos três extremos ("end-members") da deformação (Fossen et al. 1994).

Neste capítulo é feita uma síntese dos principais modelos teóricos que descrevem, em termos de deformação finita e incremental, apófises de fluxo etc., convergência e divergência oblíqua de placas, considerando a análise tridimensional da deformação.

\subsubsection{Modelos}

Uns dos primeiros autores a considerarem a deformação como uma relação tridimensional foram Sanderson \& Marchini (1984). Os autores idealizaram um modelo onde não há variação de volume, e a mudança de área causada pela aproximação dos blocos é compensada somente pelo espessamento crustal (extrusão vertical para cima). Neste 
sentido, a zona de deformação é confinada nas laterais e em sua base (figura 2.4 a). Da mesma forma, na transtração o aumento da área é compensado somente por afinamento vertical.

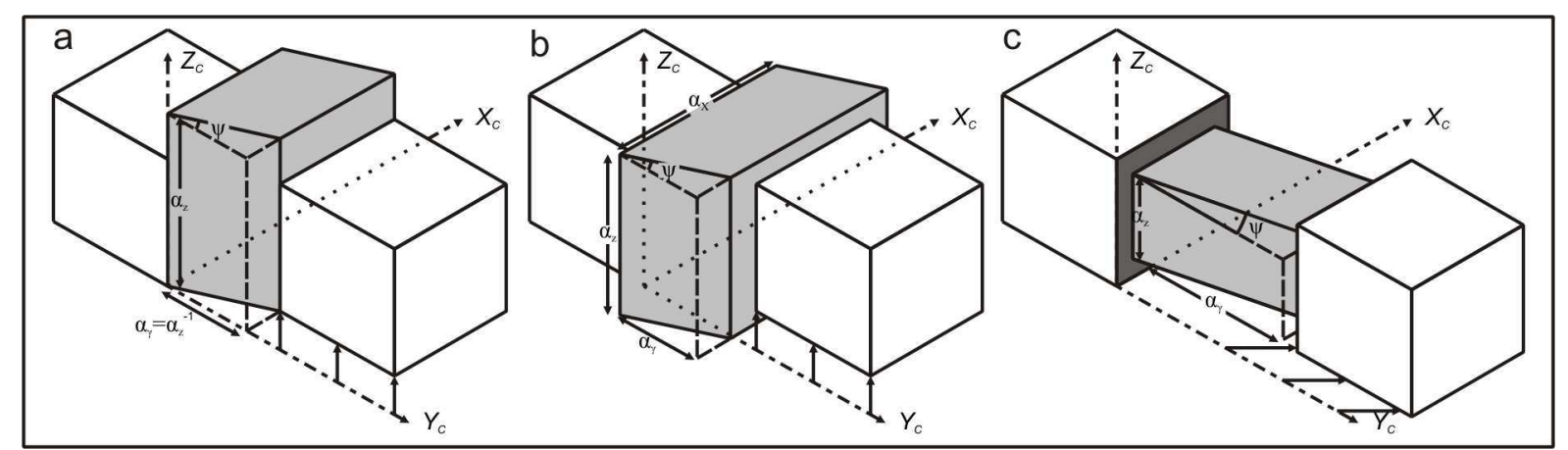

Figura 2.4 - Modelos de transpressão assumindo volume constante: a - zona confinada nas laterais e na base, com encurtamento perpendicular compensado por estiramento vertical para cima; $b-$ transpressão não-confinada, onde a compressão é acomodada por extrusão lateral, para cima e para baixo; c - transtração não-confinada, onde a extensão é acomodada por afinamento vertical e encurtamento lateral (Jones et al. 1997).

Os autores consideram que a deformação total pode ser fatorizada em componentes de cisalhamento simples e cisalhamento puro, com as variáveis $\alpha, \alpha^{-1}, \gamma$ e $\psi$ relacionadas ao estiramento vertical, encurtamento transversal à zona, cisalhamento paralelo à zona e componente não-coaxial, respectivamente.

a)

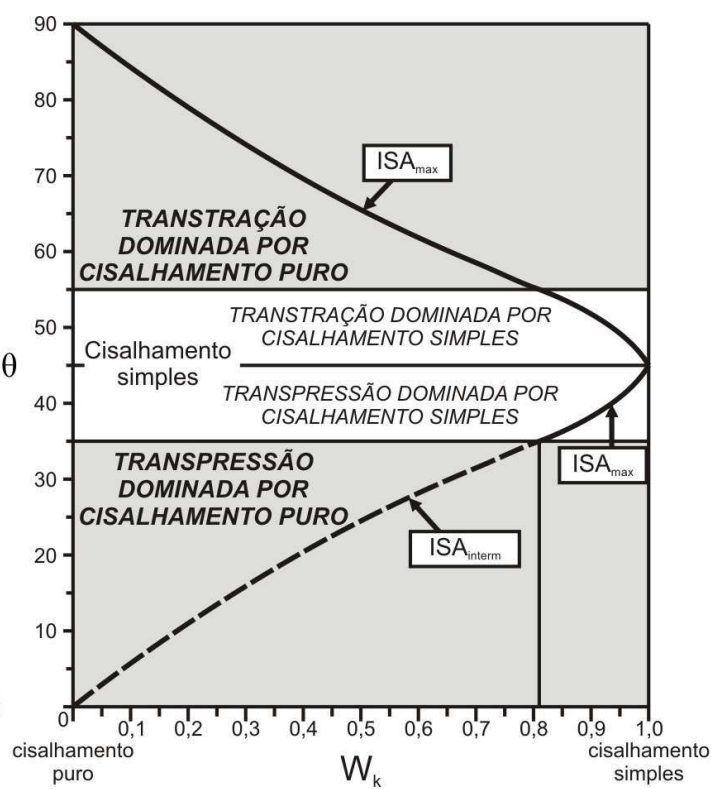

b)

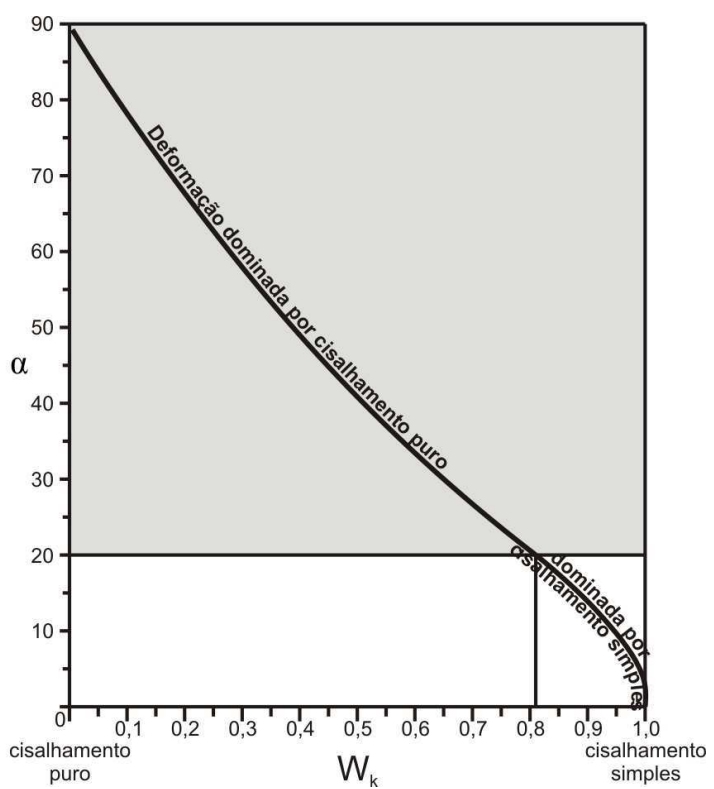

Figura 2.5 - Relações entre os ângulos $\theta$ e a (ver texto) e o número de vorticidade cinemática $\left(W_{k}\right)$, e a mudança entre deformação dominada por cisalhamento puro e dominada por cisalhamento simples (Fossen et al. 1994). 
Para Fossen et al. (1994), a fatorização entre cisalhamento puro e simples é caracterizada ainda pelo número de vorticidade cinemática $W_{\mathrm{k}}$, que corresponde à medida da não-coaxialidade da deformação. A figura 2.5 mostra a relação entre o número de vorticidade cinemática e $\theta$ (ângulo entre eixo horizontal máximo de estiramento instantâneo e o limite da zona - a), e $\alpha$ (ângulo entre apófise de fluxo horizontal oblíqua e o limite da zona). Assim, $W_{\mathrm{k}}=1$ para transcorrência pura, e $W_{\mathrm{k}}=0$ para convergência/divergência puras, e todos os valores intermediários para diferentes combinações entre cisalhamento puro e cisalhamento simples. Com base no parâmetro $W_{k}$, os autores propõem a classificação de ambientes convergentes e divergentes oblíquos, em quatro tipos, considerando o predomínio de um ou outro mecanismo de deformação, a saber:

$\checkmark$ transpressão dominada por cisalhamento simples $\rightarrow 1>W_{\mathrm{k}}>0,81$, com eixo de máximo estiramento instantâneo horizontal, orientado entre 45 - 35으 da zona de cisalhamento;

$\checkmark$ transtração dominada por cisalhamento simples $\rightarrow 1>W_{\mathrm{k}}>0,81$, com eixo de máximo estiramento horizontal, orientado entre $45-55^{\circ}$ da zona de cisalhamento;

$\checkmark$ transpressão dominada por cisalhamento puro $\rightarrow 0<W_{k}<0,81$, com eixo de estiramento máximo vertical;

$\checkmark$ transtração dominada por cisalhamento puro $\rightarrow 0<W_{\mathrm{k}}<0,81$, com eixo de estiramento mínimo vertical.

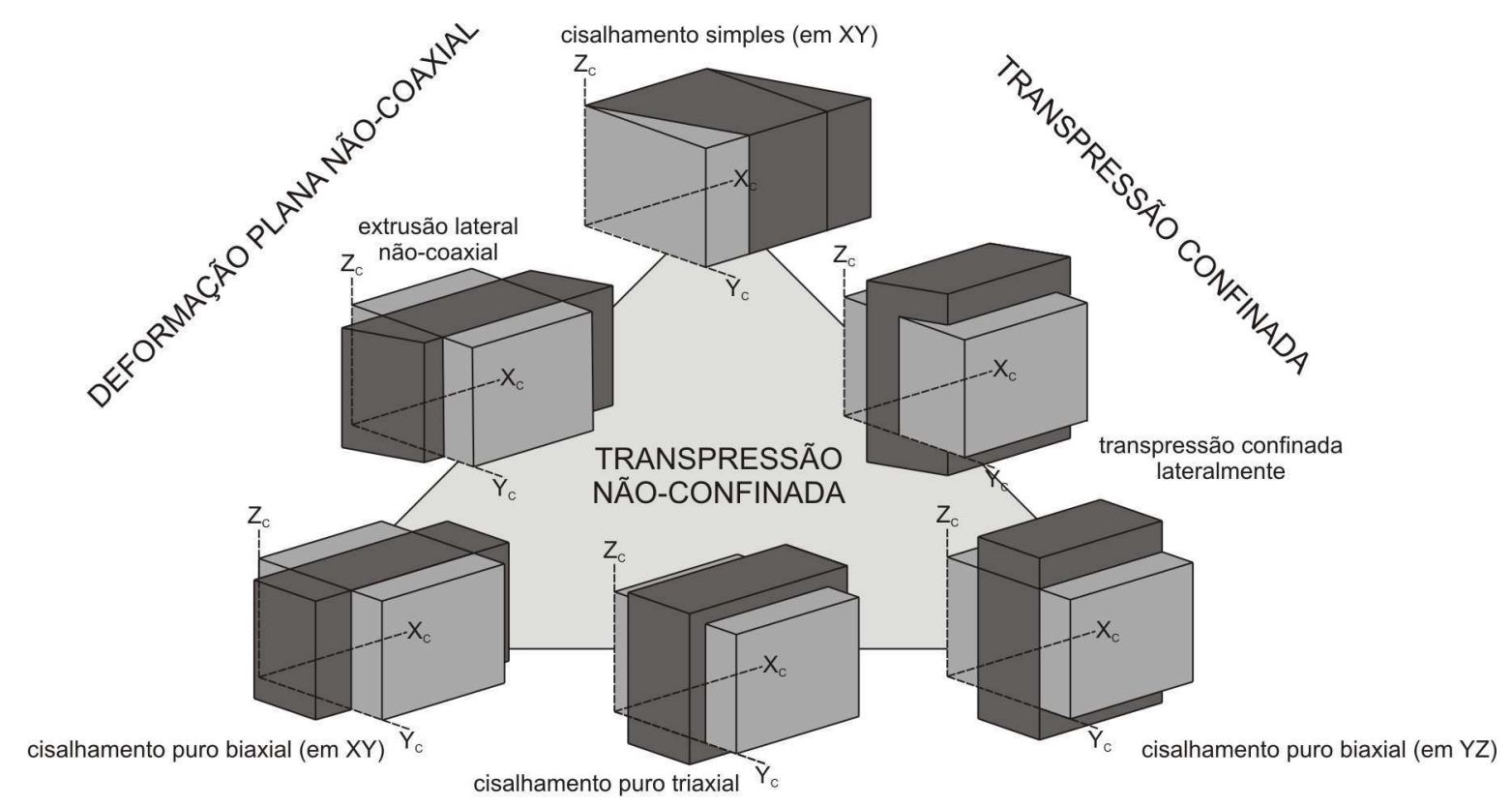

CISALHAMENTO PURO

Figura 2.6 - Diagrama mostrando a transpressão não-confinada separada em três componentes de deformação (cisalhamento puro em $X_{C} Y_{C}$, cisalhamento puro em $Y_{C} Z_{C}$ e cisalhamento simples em $X_{c} Y_{c}$ ) (Jones et al. 1997). 
Jones et al. (1997) consideram uma zona de cisalhamento sem confinamento lateral nem vertical, onde a deformação, com volume constante, pode ser acomodada por estiramento vertical e/ou horizontal (figura $2.4 \quad b \quad$ e $c$ ). Consideram a deformação transpressiva como qualquer combinação entre os três tipos finais (end-members) de deformação mostrado no gráfico da figura 2.6 (cisalhamento simples, estiramento vertical e estiramento horizontal). As arestas do diagrama correspondem à transpressão lateralmente confinada, semelhante ao modelo de Sanderson \& Marchini (1984), a deformação plana não-coaxial com estiramento lateral, e ao cisalhamento puro não confinado.

a)

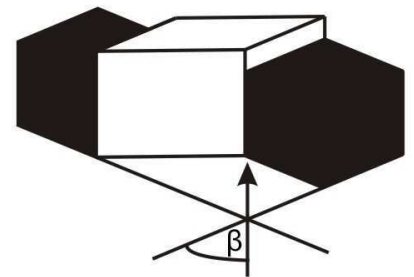

b)

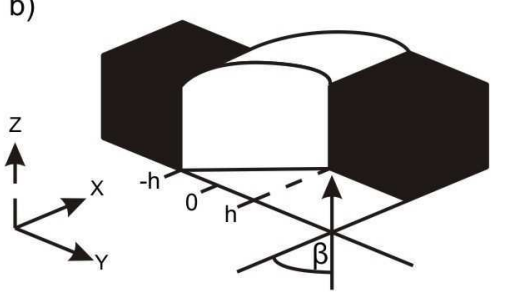

c)

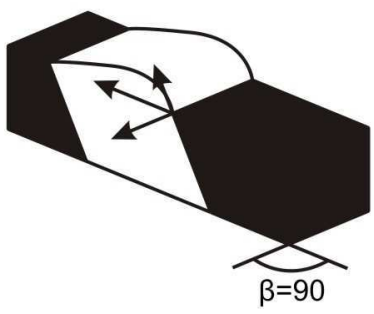

Figura 2.7 - Comparação entre os modelos de Sanderson \& Marchini (1984) (a), Robin \& Cruden (1994) (b) e Dutton (1997) (c) (extraído de Dutton, 1997). Os modelos b e c assumem não haver deslizamento de material nas margens da zona.

Os modelos de Robin \& Cruden (1994) e Dutton (1997) consideram uma zona de deformação sem qualquer deslocamento de material nas margens da zona (figura 2.7 b e c), com a existência de gradiente de deformação tanto horizontal como verticalmente (deformação heterogênea). Consideram também deslocamento vertical relativo nos muros da zona de deformação, ou seja, o ângulo $\beta$ entre a direção de cisalhamento e o plano horizontal é diferente de zero. Nesse caso denominam o regime de deformação como transpressão oblíqua, e para $\beta=0^{\circ}$, transpressão transcorrente. A relação entre cisalhamento puro e cisalhamento simples é dada por $f=\Phi / \gamma$ (componente compressivo/componente transcorrente).

\subsubsection{Elipsóides de deformacão e apófises de fluxo}

A forma do elipsóide de deformação finita esperado, segundo Sanderson \& Marchini (1984), de acordo com o componente de encurtamento perpendicular à zona varia da seguinte forma:

$\checkmark \alpha^{-1}<1(k<1)$, para deformação oblata ou transpressiva;

$\checkmark \alpha^{-1}=1(k=1)$, para deformação plana ou por cisalhamento simples; 
$\checkmark \alpha^{-1}>1(k>1)$, para deformação prolata ou transtrativa.

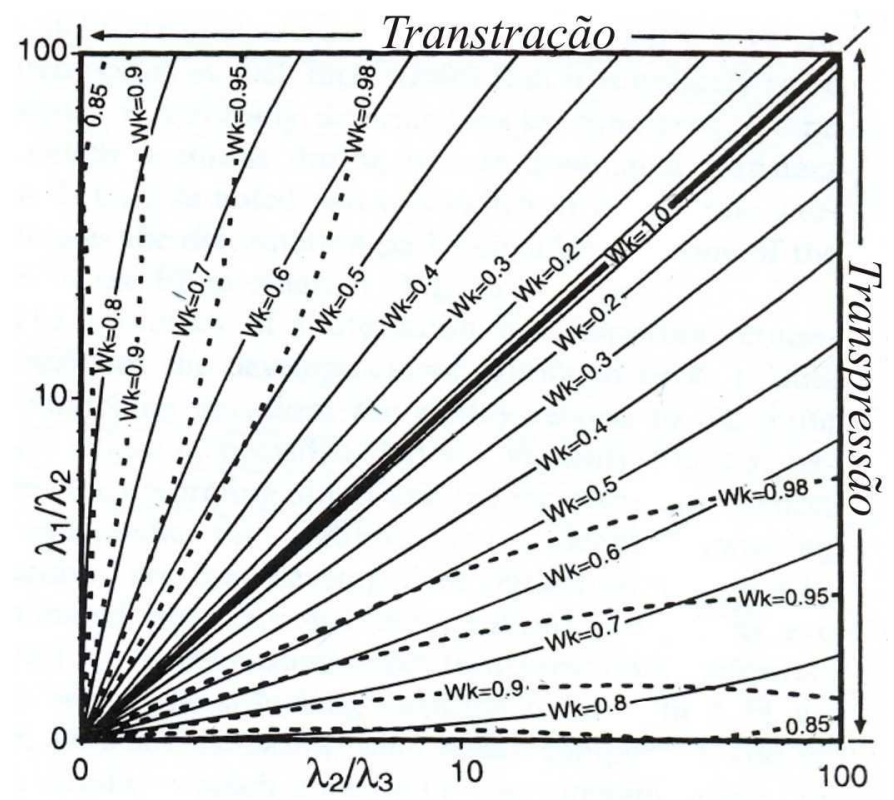

Figura 2.8 - Trajetória dos valores de $W_{k}$ em um diagrama de Flinn logarítmico. As linhas tracejadas correspondem à deformação dominada por cisalhamento simples, e as linhas cheias, por cisalhamento puro (Fossen et al. 1994).

Os eixos do elipsóide de deformação $(X>Y>Z)$ também podem apresentar variações em suas orientações de acordo com o regime atuante. Para o caso de cisalhamento simples, o eixo $Y$ é sempre vertical; para a deformação oblata com componente de encurtamento, o eixo vertical pode ser $X$ ou $Y$, com o plano $X Y$ sendo sempre vertical, mas oblíquo em relação ao limite da zona (ângulo $\theta$ ', entre o eixo máximo horizontal e o limite da zona); e para a deformação prolata, $Z$ ou $Y$ pode ser vertical, com o plano $X Y$ variando entre vertical e horizontal.

Dentro das diferentes combinações entre cisalhamento puro e cisalhamento simples propostas por Fossen et al (1994), os eixos do elipsóide de deformação $\left(\lambda_{1}>\lambda_{2}>\lambda_{3}\right)$ foram determinados considerando-se que os eixos da deformação instantânea permanecem paralelos, e $W_{\mathrm{k}}$ se mantém constante por toda história de deformação (steady-state). No diagrama de Flinn da figura 2.8 observa-se que o mesmo valor de $k$ pode estar associado com mais de um valor de $W_{k}$, o que influencia na forma final do elipsóide de deformação finita. Entretanto, se o estiramento finito máximo, $v$, for conhecido (figura 2.9), a orientação dos eixos do elipsóide pode ser inferida, de tal modo que, para transpressão dominada por cisalhamento puro, $\lambda_{1}$ é vertical (para transpressão, e para transtração, $\lambda_{3}$ é vertical) e $\lambda_{2}$ e $\lambda_{3}$ (ou $\lambda_{1}$ ) são horizontais e oblíquos à zona. O elipsóide de deformação finita inicia-se paralelo ao elipsóide de deformação instantânea, porém, com a evolução da deformação, $\lambda_{2}$ torna-se 
progressivamente paralelo à zona, e $\lambda_{3}$ perpendicular a esta. Essa rotação ocorre devido à existência do componente não-coaxial (Fossen \& Tikoff, 1993 e Tikoff \& Teyssier, 1994).

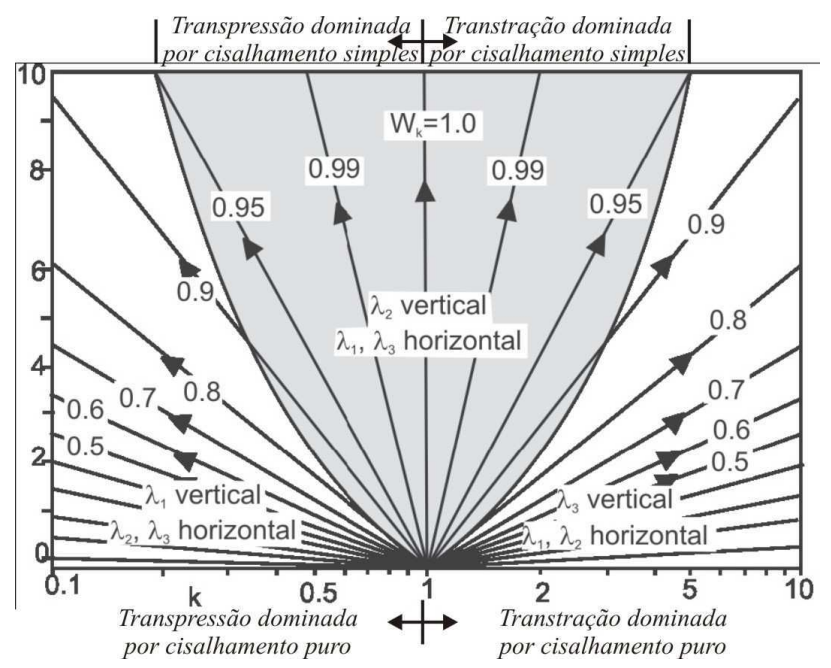

Figura 2.9 - Modelo com as possíveis orientações do elipsóide de deformação finita em função dos componentes de cisalhamento simples e cisalhamento puro (extraído de Fossen et al. 1994).

Segundo Fossen et al (1994), para qualquer situação na qual a deformação é dominada por cisalhamento simples, $\lambda_{1}$ ou $\lambda_{3}$ (transpressão ou transtração) são verticais, e trocam de posição com $\lambda_{2}$ durante a deformação progressiva $\left(W_{\mathrm{k}} \approx 0,81\right)$, tornando-se este vertical na sua forma final. No entanto, para Tikoff \& Teyssier (1994), o maior e o menor eixos de deformação instantânea são horizontais $\left(s_{1}\right.$ e $\left.s_{3}\right)$, e, da mesma forma, o elipsóide de deformação finita é paralelo no início, mas $\lambda_{1}$ troca de posição com $\lambda_{2}$, tornando-se vertical (figura 2.10).
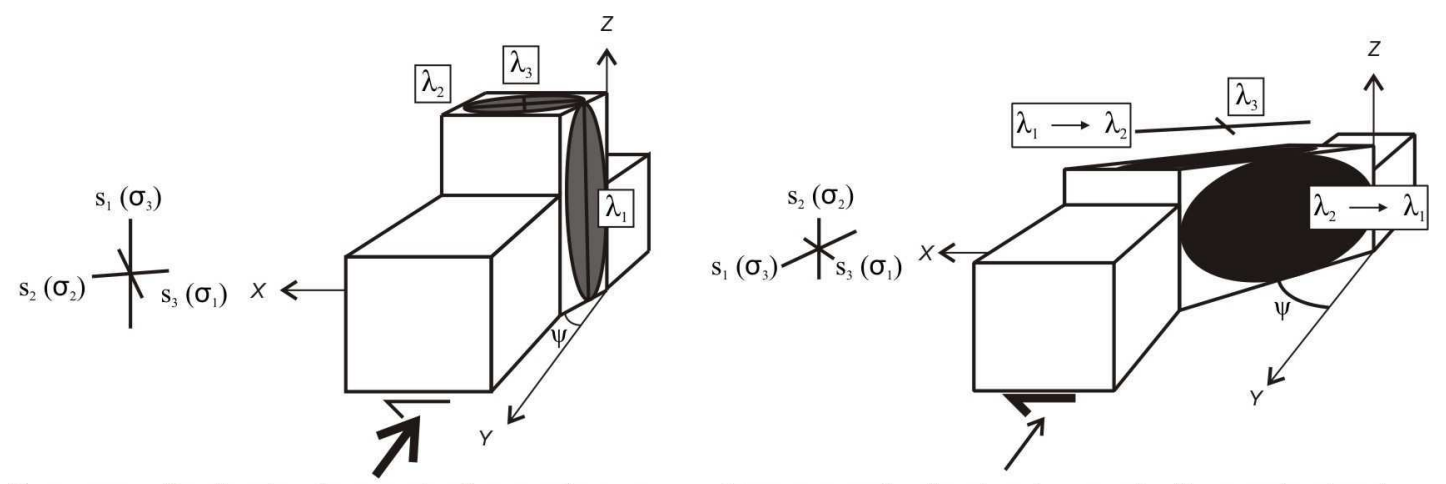

Transpressão dominada por cisalhamento puro

Transpressão dominada por cisalhamento simples

Figura 2.10 - Tipos de transpressão e os eixos de deformação instantânea segundo Tikoff \& Teyssier (1994). Na transpressão dominada por cisalhamento puro, o componente de cisalhamento puro domina as deformações instantânea e finita. Na transpressão dominada por cisalhamento simples, o componente de cisalhamento puro, apesar de menor, é mais eficiente que o componente de cisalhamento simples na deformação finita. 


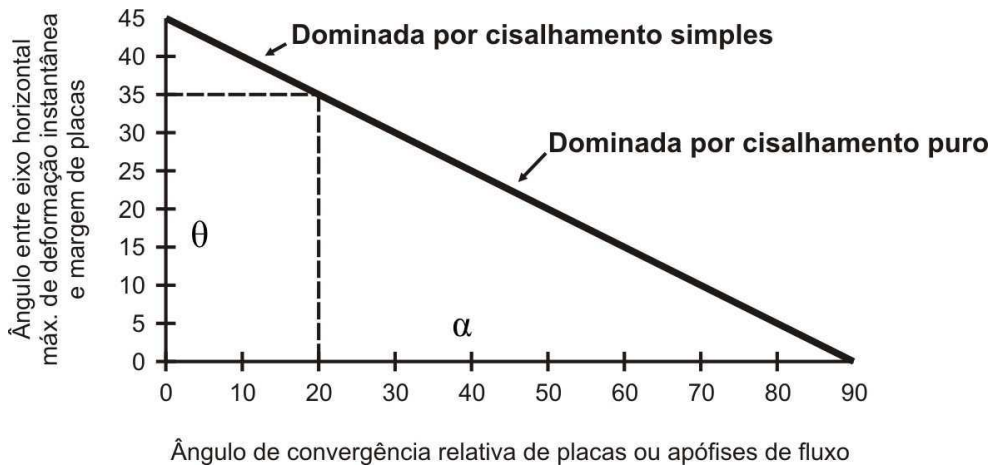

Figura 2.11 - Relação entre os ângulos a (ângulo entre a apófise contracional do fluxo ou direção de máxima velocidade de convergência em regime transpressivo e a margem) e $\theta$ (ângulo entre o eixo de deslocamento máximo instantâneo e a margem) (ver texto para explicação mais detalhada) (Tikoff \& Teyssier 1994).

Nos trabalhos citados acima (Fossen et al. 1994 e Tikoff \& Teyssier 1994), a modelagem da deformação é feita também baseada no fluxo de partículas. Esse fluxo é representado, num dado instante da deformação, pelas apófises de fluxo, ou seja, eixos de máximo, intermediário e mínimo gradientes de velocidade. Para a transpressão, uma apófise é sempre extensional e vertical (paralela a $Z$ ), uma é neutra, horizontal, paralela ao eixo $X$, e outra é contracional, horizontal e oblíqua ao mesmo (Tikoff \& Teyssier 1994). Segundo estes autores, as apófises estão diretamente associadas à movimentação relativa de placas, sendo o vetor de movimento paralelo à apófise contracional. Em relação ao elipsóide de deformação instantânea, as apófises apresentam uma relação linear com $S_{3}$, já que a deformação instantânea é resultado direto do deslocamento relativo no plano que contém as apófises (figura 2.11). Como mostra no gráfico, o vetor de movimento relativo e $S_{3}$ são coincidentes apenas para convergência pura.
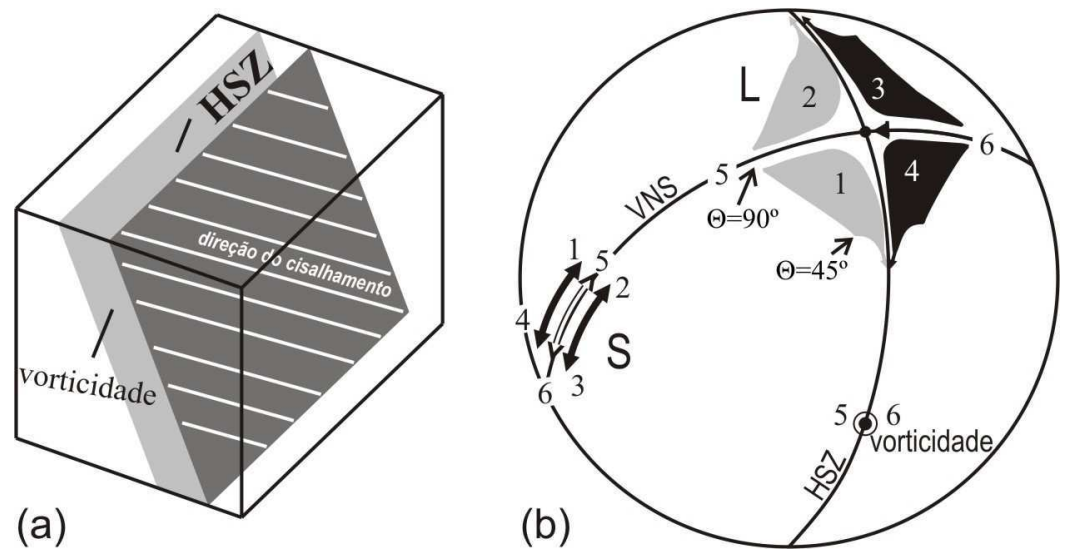

Figura 2.12 - Esquema mostrando a geometria da deformação finita teórica para vários caminhos de deformação: a - bloco diagrama de uma zona de deformação inclinada com cisalhamento oblíquo, $b$ - geometria da deformação finita resultante, onde $S$ representa os pólos da "foliação" ou $\lambda_{3}$, e $L$ representa $\lambda_{1}$, ou "lineação" (Jiang et al. 2001). 
Jiang et al. (2001) afirmam que uma apófise de fluxo é paralela ao vetor movimento relativo somente para uma zona confinada lateralmente, onde o estiramento lateral é constante (Sanderson \& Marchini 1984). Para estes autores, a deformação não é uma resposta direta ao campo de esforços, depende também da vorticidade e das características de fluxo do material. Sendo assim, um mesmo campo de esforços é compatível com vários caminhos de deformação. Na figura 2.12, os autores comparam um caso de deformação finita com vários caminhos de deformação possíveis. Os casos 3, 4 e 6 apresentam componente normal de deslocamento, e os casos 1, 2 e 5, componente inverso. Nos casos 1 e 4, o estiramento paralelo ao mergulho é dominante, enquanto nos casos 2 e 3 , ele passa a ser dominante paralelo à zona. Os casos 5 e 6 apresentam simetria monoclínica. Segundo Jiang \& Williams (1998), a simetria monoclínica de deformação ocorre somente quando $\rho=90^{\circ}$ ou $0^{\circ}$ (ângulo entre a direção cisalhante e a direção da zona) ou quando o estiramento vertical é igual ao estiramento horizontal.

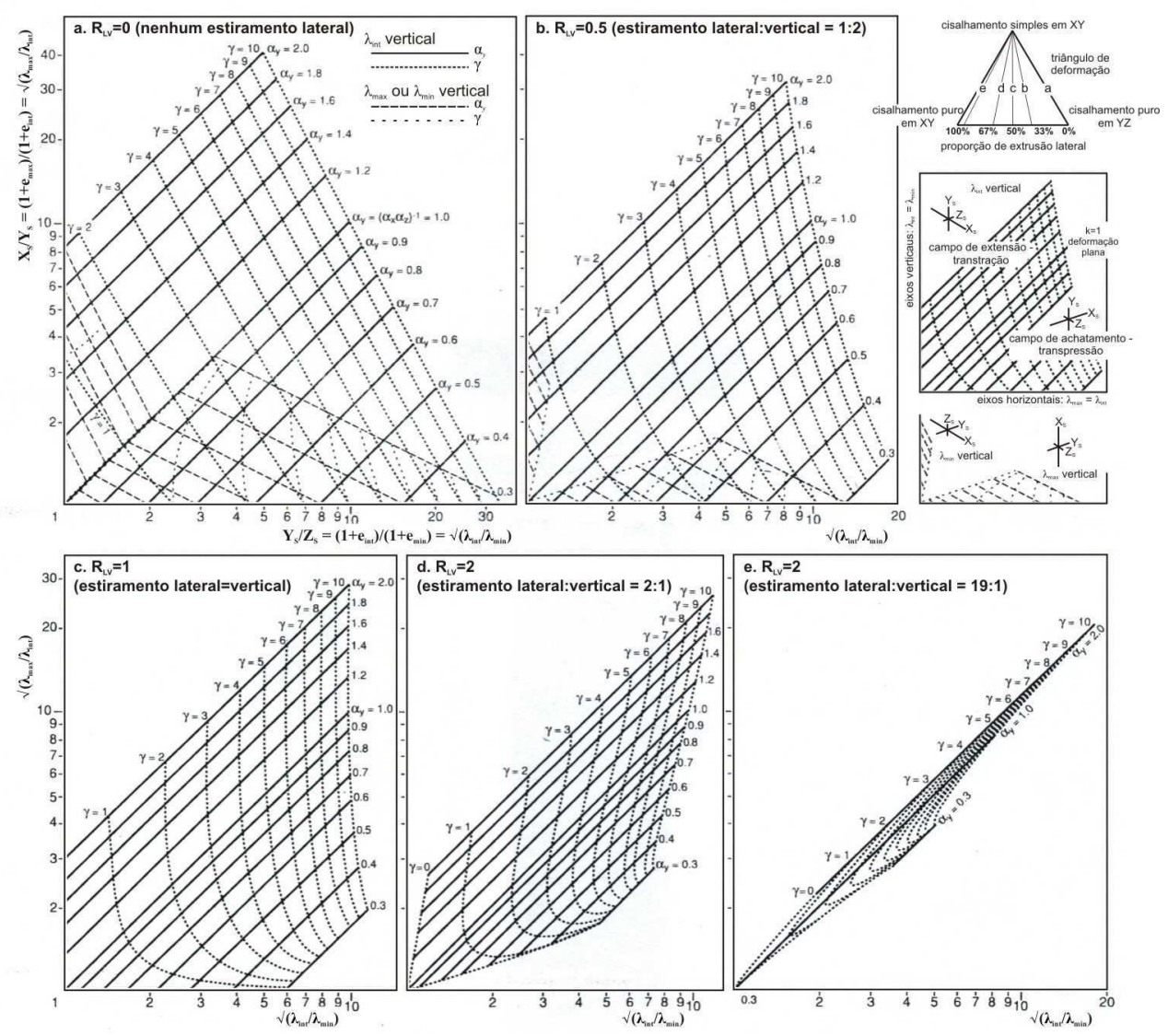

Figura 2.13 - Diagramas de Flinn mostrando as possíveis geometrias do elipsóide de deformação finita para diferentes razões $R_{L v}$ : a - transpressão confinada; $b$ a e - relação crescente de estiramento lateral (Jones et al, 1997).

No modelo de Jones et al. (1997), a relação entre estiramento horizontal e vertical tem uma forte influência na forma do elipsóide de deformação finita, porém não influenciam 
significativamente na orientação dos eixos $\left(X_{\mathrm{s}}>Y_{\mathrm{s}}>Z_{\mathrm{s}}\right)$. A figura 2.13 mostra que na transpressão confinada lateralmente, a geometria do elipsóide é resultado de uma única combinação de cisalhamento puro e simples (gráfico a), enquanto que, quando se considera a razão extensão lateral/extensão vertical, $R_{\mathrm{LV}} \neq 0$ (gráficos $b$ a $e$ ), essa geometria se torna uma variável para definir a forma do elipsóide. Para altas razões $R_{\mathrm{LV}}$, a forma do elipsóide se aproxima da deformação plana, sendo que se $R_{\mathrm{LV}} \rightarrow \infty$, enquanto $k \rightarrow 1$. Somente quando não há estiramento lateral, ou quando este é menor que o estiramento vertical, $Y_{\mathrm{s}}$ pode ser tanto vertical como horizontal, enquanto para $R_{\mathrm{LV}}>1, Y_{\mathrm{S}}$ é sempre vertical. Quando o estiramento lateral é dominante, não há possibilidade do desenvolvimento de elipsóides totalmente prolatos ou oblatos.
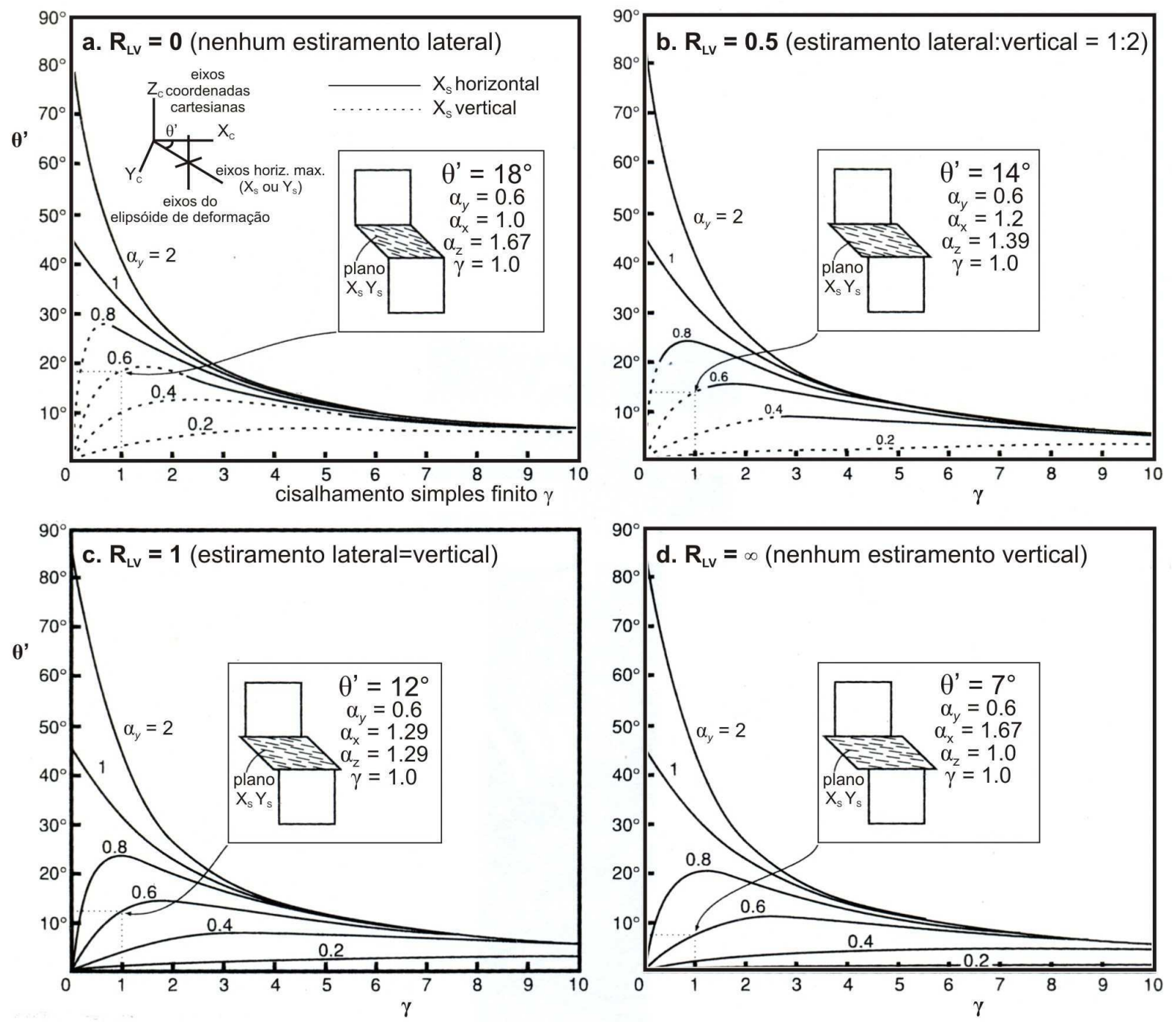

Figura 2.14 - Gráficos mostrando a orientação do maior eixo horizontal da deformação finita para vários valores de $R_{L V}$ (Jones et al, 1997).

Quanto à orientação do elipsóide em relação ao contorno da zona $\left(\theta^{\prime}\right)$, a figura 2.14 mostra que $R_{\mathrm{LV}}$ tem uma pequena influência em $\theta$ ', o que pode "equivocar" análises 
estatísticas feitas com dados de campo, a não ser que seja possível quantificar a relação $R_{\mathrm{LV}}$. Os gráficos da figura mostram também que o eixo $X_{\mathrm{S}}$ pode ser vertical somente para transpressão com espessamento vertical dominante (Jones et al. 1997).
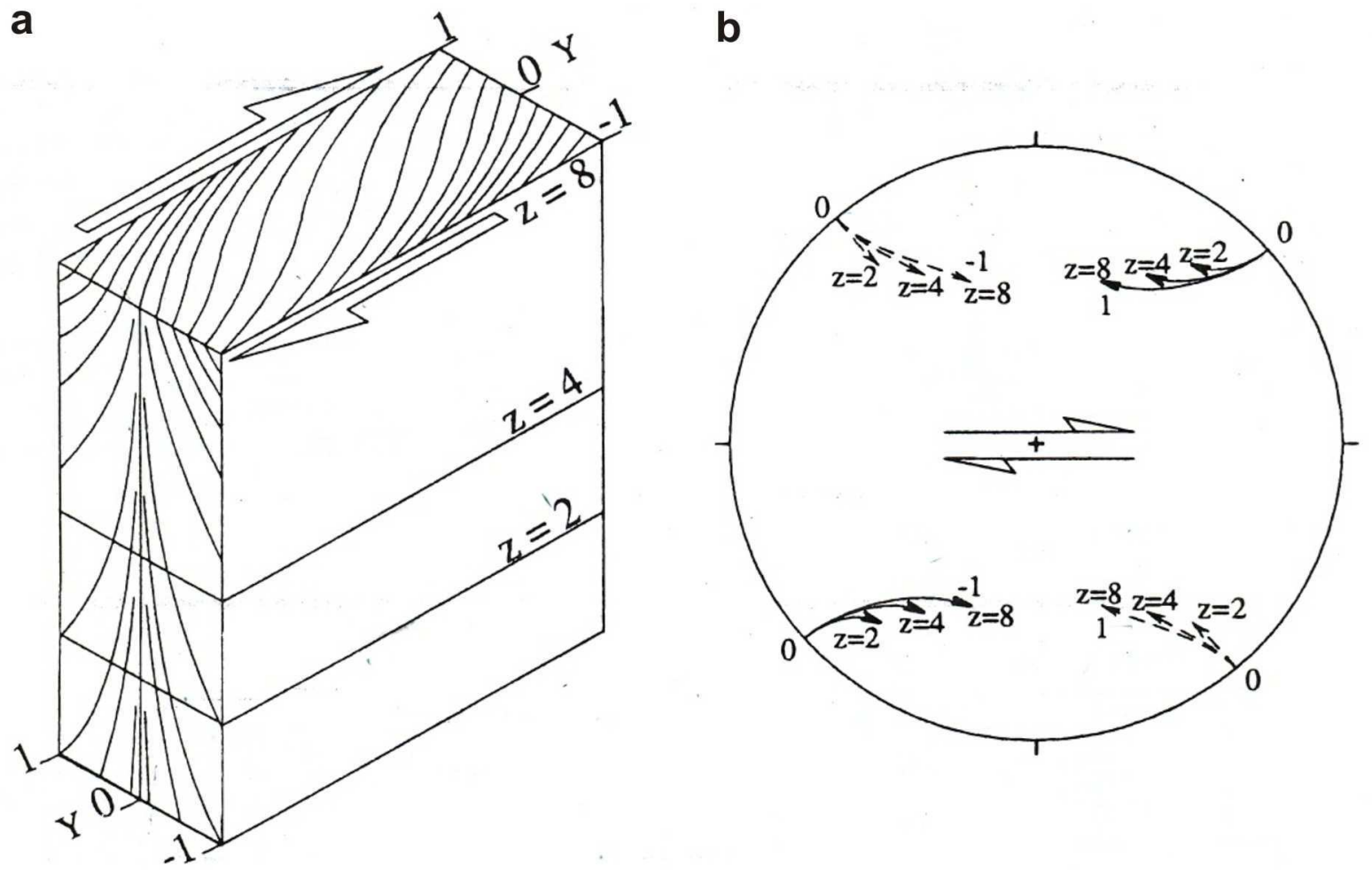

Figura 2.15 - Comportamento da "foliação" e "lineação" para transpressão transcorrente destral no modelo de Robin \& Cruden (1994): a - bloco diagrama mostrando os traços da "foliação"; $b$ estereograma mostrando as mudanças na "lineação" (linhas cheias) e nos pólos da "foliação" (linhas tracejadas) através da zona.

Já os modelos sem deslizamento nas margens (Robin \& Cruden, 1994 e Dutton, 1997) caracterizam a deformação em função do plano de achatamento instantâneo ("foliação", correspondente ao plano $s_{1}$ e $s_{2}$ ) e da direção de máxima extensão ("lineação", direção $s_{1}$ ). Vale lembrar que os termos "foliação" e "lineação" aqui utilizados não correspondem à foliação e lineação impressa nas rochas resultantes da deformação total acumulada. Para transpressão transcorrente (sem deslocamento vertical entre as paredes), todos os parâmetros mostram um padrão simétrico em relação ao plano YZ (Robin \& Cruden, 1997). A "foliação" apresenta um aumento no ângulo de mergulho em direção ao centro da zona, tornando-se vertical (figuras 2.15 e 2.16). O ângulo de mergulho da foliação diminui conforme aumenta o componente compressivo na razão $f=\Phi / \gamma$. No plano horizontal ocorre um aumento da obliqüidade em relação à direção das margens (figura 2.15).

A "lineação" também mostra uma forte dependência da razão $f$. Para baixos valores de $f$, esta se apresenta horizontal no centro da zona, tornando-se subvertical em direção às 
margens. Nessas áreas, a "lineação" pode não ocorrer ou ser muito fraca devido ao baixo valor de $k$. Para maiores valores de $f$, a "lineação" se mostra vertical em toda zona modelada (tanto na vertical como na horizontal). A figura 2.16 sintetiza os padrões de fábrica para transpressão transcorrente, mostrando também o comportamento do vetor vorticidade ao longo da zona.
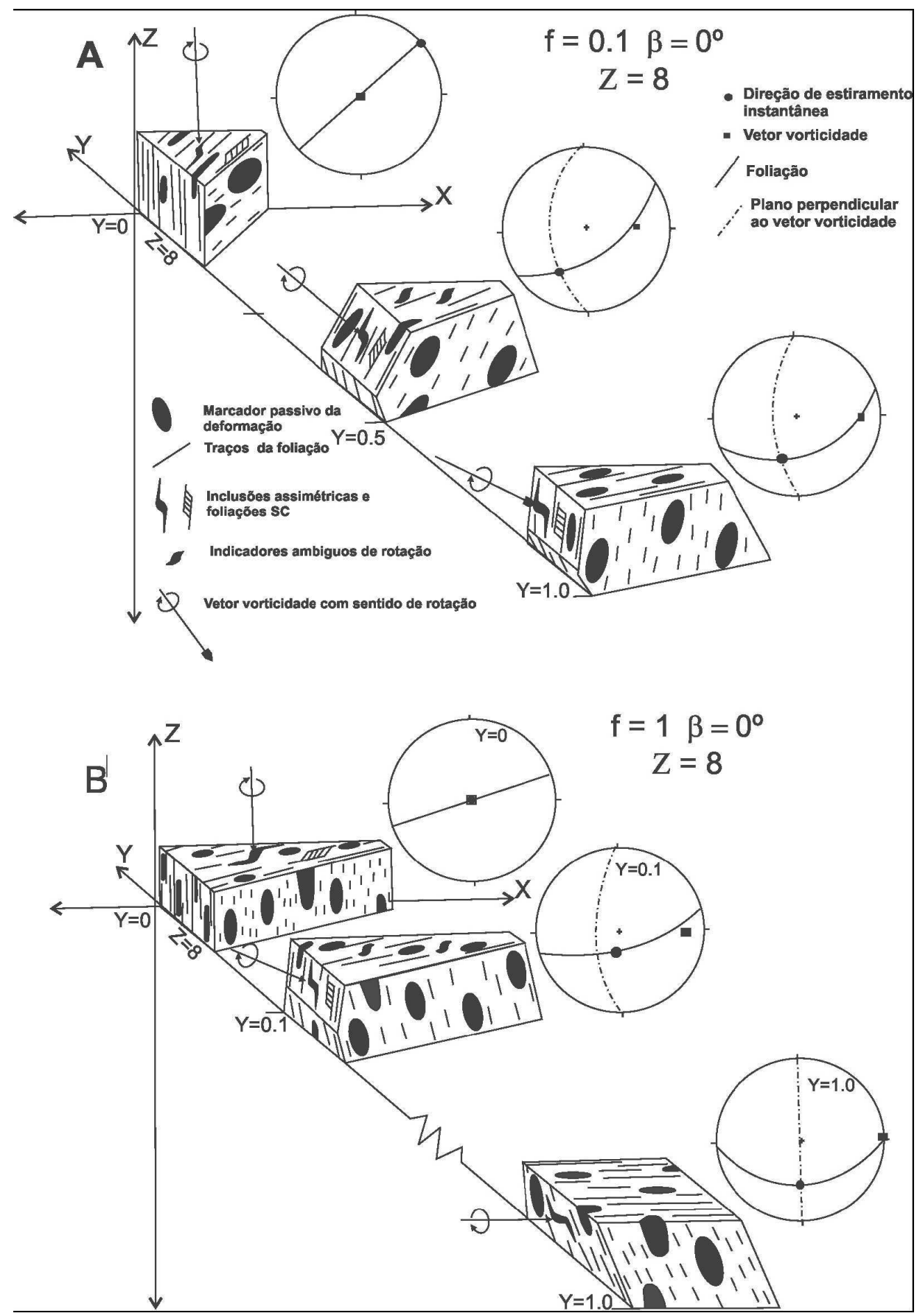

Figura 2.16 - Fábricas e padrões cinemáticos previstos para duas relações de cisalhamento puro e cisalhamento simples em zonas transcorrentes destrais, considerando diferentes distâncias do centro da zona (Y) (Robin \& Cruden, 1994). 


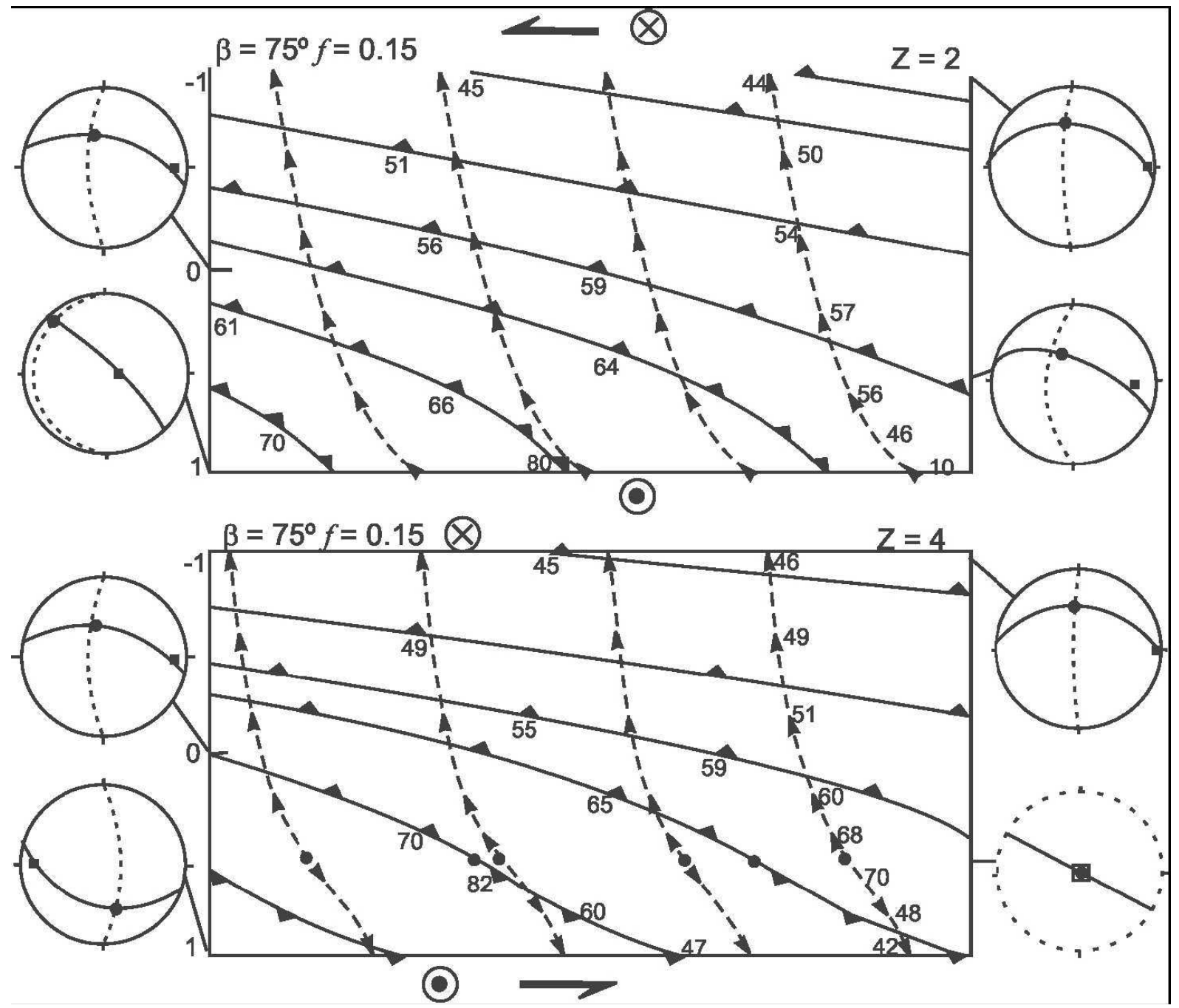

Figura 2.17 - Mapa de trajetória da "foliação" (linha cheia) e "lineação" (linha tracejada) para dois níveis horizontais, para transpressão oblíqua sinistral, com $\beta=75^{\circ}$. Projeções estereográficas mostram a relação entre o vetor vorticidade (quadrado), o plano perpendicular a ele (grande círculo tracejado), "foliação" (linha cheia) e "lineação" (círculo) (Robin \& Cruden, 1994).

Quando se considera o deslocamento vertical entre os muros, $\beta \neq 0$, o padrão de fábrica deixa de ser simétrico em relação ao centro, e é fortemente dependente da profundidade. Em planta, o comportamento da "foliação" e "lineação" pode ser visto na figura 2.17, para dois níveis diferentes. Num nível mais profundo, a "lineação" apresenta alto rake em direção à "lapa", rotacionando através da zona e tornando-se paralela à "foliação". A obliqüidade em relação às margens, tanto da "lineação" quanto da "foliação", segundo os autores, é uma resposta à deformação instantânea inicial, sendo estas rotacionadas com ângulos menores na deformação finita. Porém, em níveis mais rasos, ocorre uma inversão da "foliação" e "lineação" na direção da "capa", relacionada à extrusão, e uma predominância local de deformação transcorrente. 
Dutton (1997), além do parâmetro $\beta$, introduz uma variável relacionada à inclinação nos limites da zona, o que produz um componente cisalhante paralelo ao mergulho das paredes $(\delta)$. Nesta modelagem, as condições de contorno (boundary conditions) para a transpressão foram realizadas, considerando uma espessura constante da zona transpressiva. O autor observa que o fato das paredes da zona não ser vertical exerce pouca influência na simetria das estruturas, até que o parâmetro $\delta$ atinja aproximadamente $10^{\circ}$, o que corresponde a sistema de empurrões oblíquos, e não a zonas transpressivas.

\subsubsection{Estruturas lineares, planares e indicadores de movimento esperados}

Sanderson \& Marchini (1984) sugerem que as orientações favoráveis para nucleação de fraturas, falhas e dobras são controladas essencialmente pelo fluxo por cisalhamento simples numa zona transcorrente subvertical, sendo então diferentes nos casos que envolvem transpressão, transtração e transcorrência (figura 2.18). Neste modelo, o ângulo de nucleação das dobras e falhas em zonas transcorrentes é de $45^{\circ}$ em relação à zona de cisalhamento, enquanto em zonas de transpressão e transtração esse ângulo é menor e maior, respectivamente, devido à presença de cisalhamento puro perpendicular à zona. Com a deformação progressiva, as dobras (En-échelon) previamente formadas por cisalhamento simples, com ângulo de $45^{\circ}$ em relação à zona, são rotacionadas, enquanto novas dobras são formadas com o mesmo ângulo inicial, resultando assim em uma obliqüidade entre dobras resultantes de uma mesma deformação.

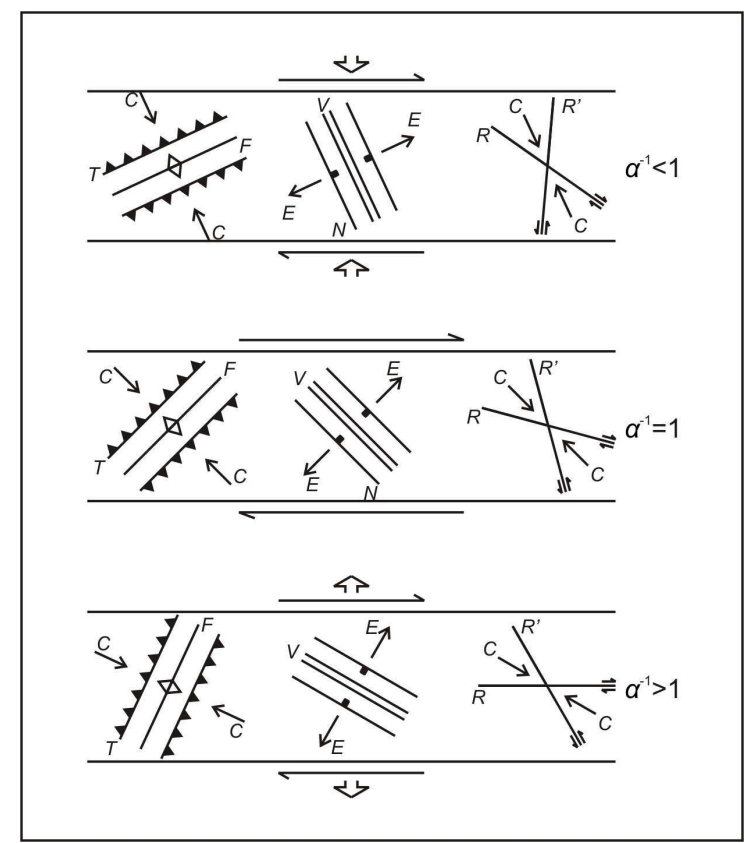

Figura 2.18 - Figura ilustrando a orientação de estruturas no modelo transpressivo. $C$ - eixo de compressão; $E$ - eixo de extensão; $N$ - falhas normais; $T$ - falhas de empurrão; $R$ e $R$ ' - falhas de Riedel; $V$ - veios, diques e fraturas de extensão; $F$ - eixos de dobras (Sanderson \& Marchini 1984). 
Fossen et al. (1994) usam as direções dos eixos do elipsóide de deformação finita esperados para prever o comportamento de fábricas $S$ e $L$ e da lineação de estiramento, nos quatro tipos de regime deformação baseados no $W_{k}$, sintetizados na tabela 2.2.

Tabela 2.2 - Orientações de foliação e lineação de estiramento mineral esperadas para os tipos de transpressão e transtração descritos acima (Extraído de Fossen et al. 1994).

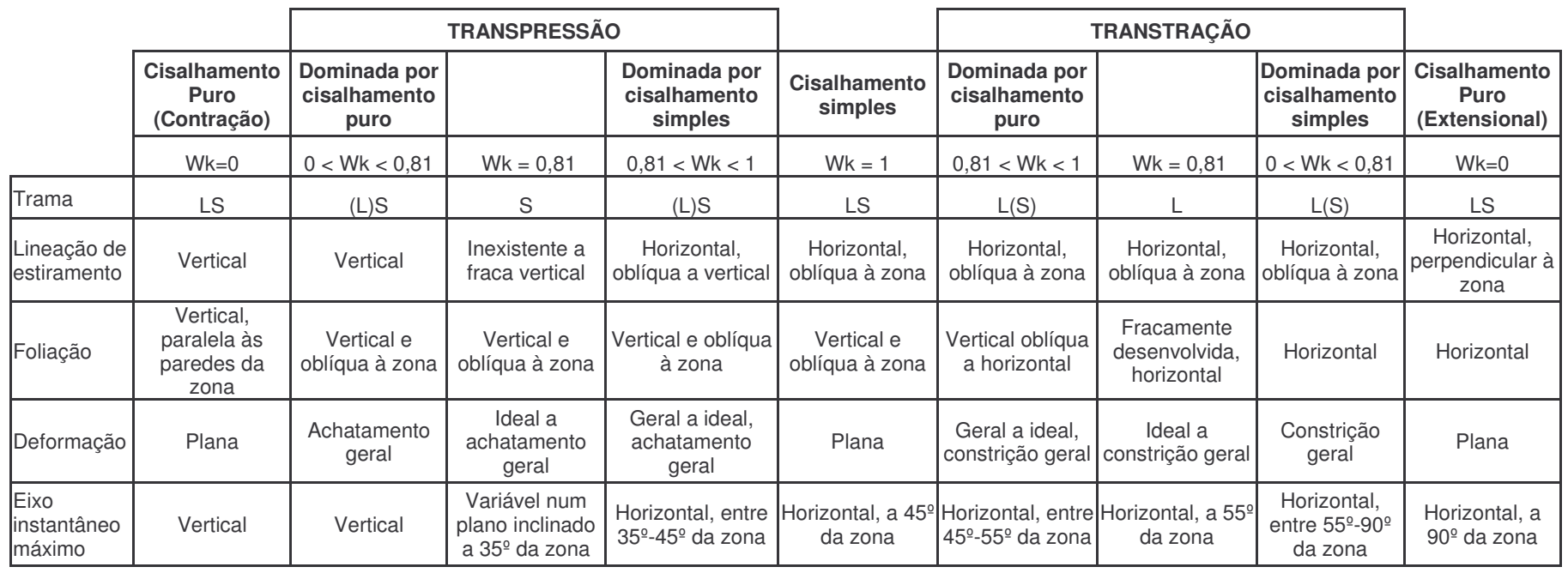

Nesse modelo, os autores prevêem ainda a rotação de feições lineares e planares préexistentes ou formadas durante a deformação progressiva, com base no fluxo de partículas. Sugerem também que a rotação desses elementos ocorre de acordo com a figura 2.19, em um sistema de cisalhamento simples sinistral, envolvendo vários casos de transpressão e transtração. Para os marcadores planares, no caso do cisalhamento simples, os pólos migram ao longo de grandes círculos, com todos os planos tendendo a se tornarem verticais com a deformação progressiva.

A obliqüidade entre os eixos de deformação finita e instantânea deve resultar na coexistência de estruturas típicas de deformação transcorrente e contracional (Tikoff \& Teyssier 1994). Em uma zona de cisalhamento vertical, dominada por cisalhamento simples, a deformação instantânea será responsável pela geração de estruturas primárias transcorrentes (ver orientação de elipsóides no item "Elipsóides de deformação e apófises de fluxo") seguidas por estruturas contracionais, resultantes da deformação finita. De maneira semelhante, na deformação dominada por cisalhamento puro, serão formadas estruturas contracionais típicas de deformação instantânea e, posteriormente, estruturas transcorrentes. Essa é a base do conceito da partição da deformação, que será discutida a seguir. 


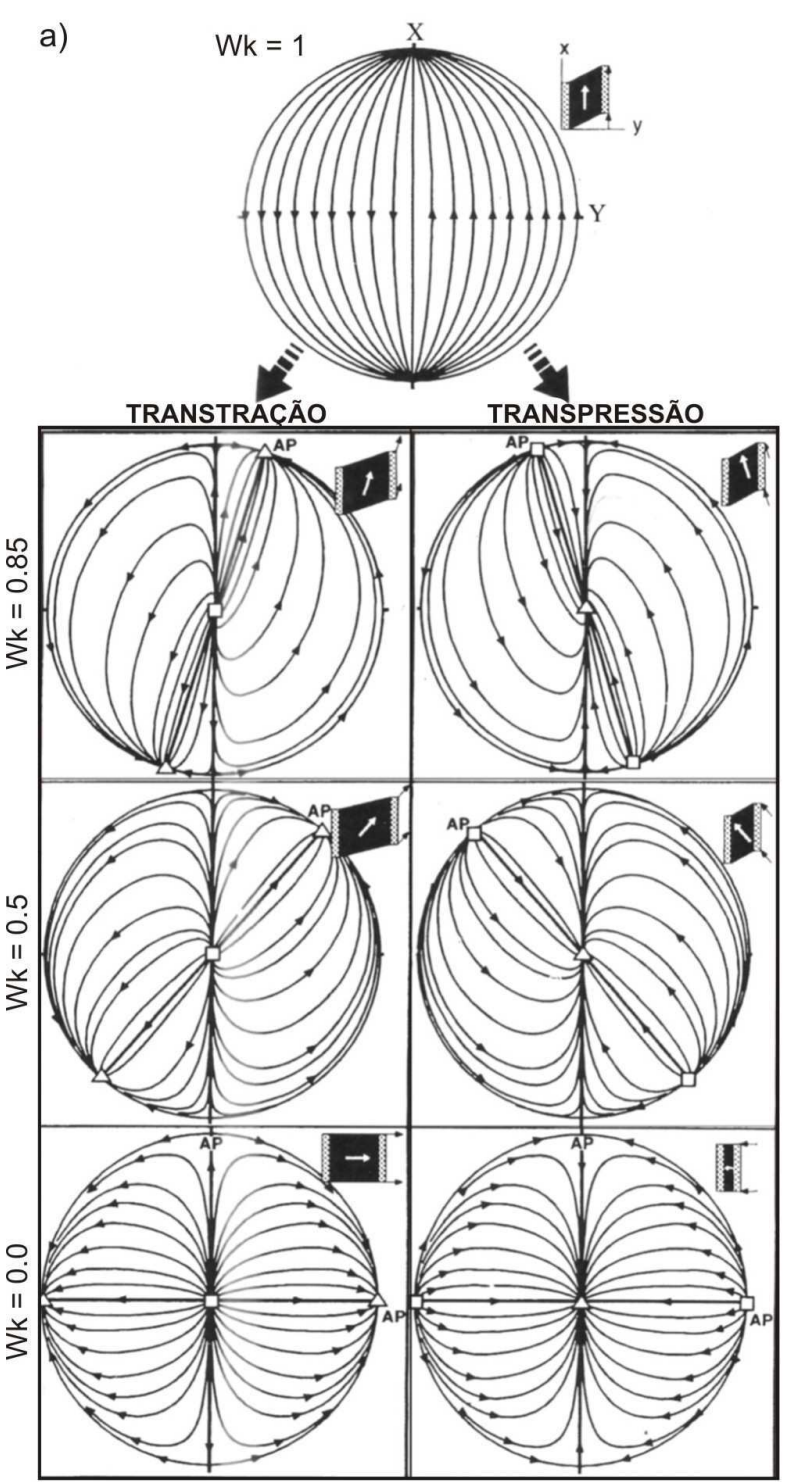

口 "Origem" (metaestável) $\triangle$ "Destino" (estável)
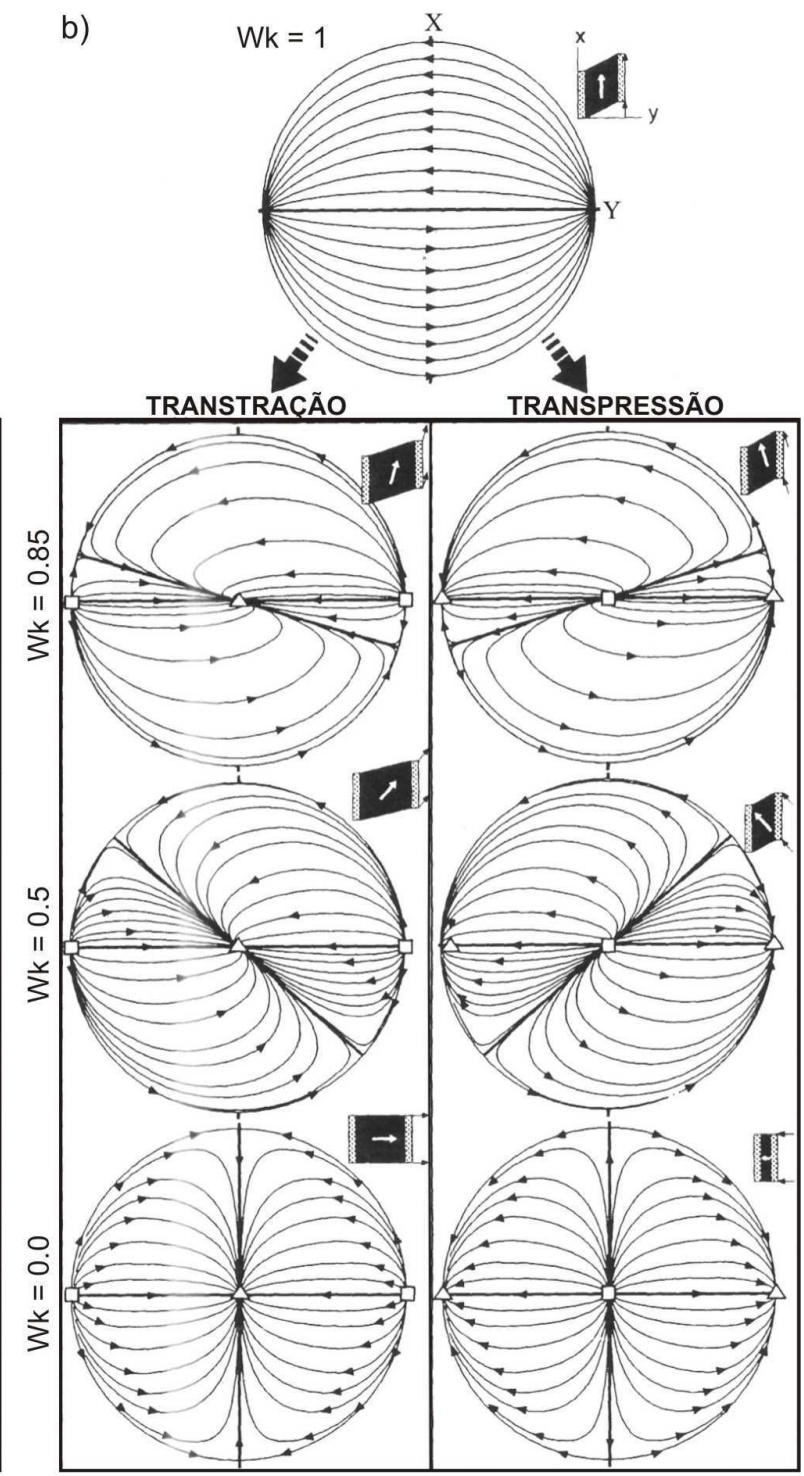

口 "Origem" (metaestável) $\triangle$ "Destino" (estável)

Figura 2.19 - Rotação de marcadores passivos para cisalhamento simples sinistral, envolvendo vários casos de transpressão e transtração, e cisalhamento puro; (a) - marcadores lineares, (b) marcadores planares (pólos dos planos) (Fossen et al. 1994).

Em relação aos indicadores cinemáticos, Jones et al (1997) mostram que movimentos antitéticos no interior de uma zona de deformação não precisam ser explicados por diferentes fases de deformação. Em ambientes não-confinados lateralmente, o material deve ser deslocado em sentidos opostos àquele da deformação por cisalhamento simples considerado para a zona inteira (ver figura 2.20). O mesmo acontece para zonas nãoconfinadas verticalmente, onde há deslocamento para baixo na transpressão e para cima na transtração. 


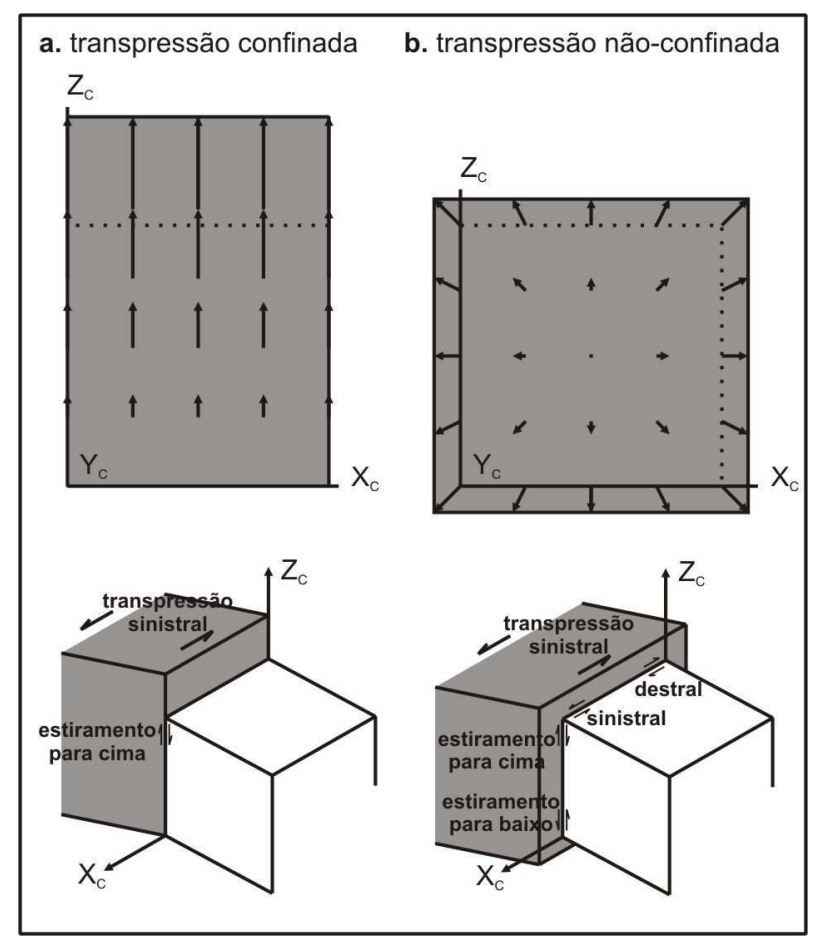

Figura 2.20 - Esquema de vetores deslocamento mostrando o movimento relativo de partículas na zona de deformação adjacentes ao limite da zona. (a) - zona de deformação confinada na base e nas laterais, onde o movimento das partículas ocorre apenas para cima; (b) - zona de deformação nãoconfinada, onde ocorre extrusão lateral e espessamento vertical para cima e para baixo (Jones et al. 1997).

\subsubsection{Partição da deformação}

A deformação transpressiva/transtrativa não ocorre de maneira homogênea ao longo da zona de deformação. Tikoff \& Teyssier (1994), Fossen et al. (1994), entre outros autores, sugerem que o componente de cisalhamento simples aumenta em direção ao centro da zona de cisalhamento, mas essa mudança não deve ser considerada gradual. A deformação é particionada em domínios diferenciados pela predominância de cisalhamento puro e cisalhamento simples, e essa alternância pode ocorrer desde a escala de centímetros até dezenas de quilômetros.

Propuseram um modelo de partição da deformação em ambientes transpressivos e transtrativos, onde o componente de cisalhamento simples é particionado em planos discretos, e o componente de cisalhamento puro, em domínios mais amplos (figura 2.21). Cada uma dessas zonas apresenta seu próprio elipsóide de deformação finita, direção de estiramento instantâneo, rotação de marcadores passivos e orientações de linhas e planos deformados. 

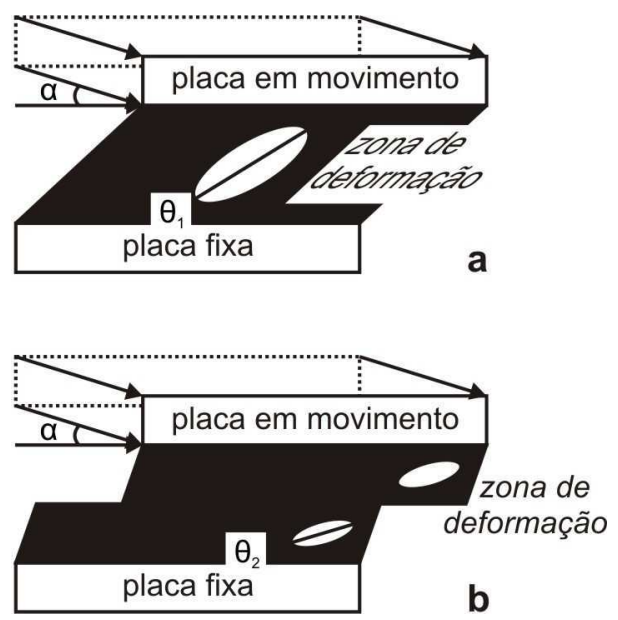

Figura 2.21 - Esquema de duas placas convergindo com um ângulo $\alpha$, e o limite de placas caracterizado por deslocamento distribuído (a) e deslocamento particionado (b) (Tikoff \& Teyssier, 1994).

Quando o movimento é particionado dessa forma, deve diminuir o $W_{k}$ da zona, e aumentar o componente de cisalhamento puro. Assim, essa partição pode ser entendida como uma razão entre o componente de cisalhamento simples, concentrado em planos discretos, e o componente de cisalhamento puro, que permanece distribuído na zona deformada.

Portanto, há uma relação entre o $W_{\mathrm{k}}$ induzido pelo movimento relativo das placas, o $W_{\mathrm{k}}$ interno na zona transpressiva, e a porcentagem do componente de cisalhamento simples, acomodado em zonas de cisalhamento ou falhas discretas.

Para Teyssier et al. (1995), um aumento no componente de movimento transcorrente na falha resulta num maior componente de cisalhamento puro na zona difusa. Assim, a direção de máximo encurtamento instantâneo vai tornando-se perpendicular ao limite da placa à medida que aumenta o grau de partição transcorrente. Considerando que a deformação instantânea gerada por movimento de placa é consistente com movimento em falhas transcorrentes, a deformação finita acomoda deformação contracional progressiva, que favorece o desenvolvimento de dobras e estruturas de empurrão. A partição transcorrente é favorecida onde a transpressão é dominada por cisalhamento simples.

No modelo de Jones et al. (1997) (figura 2.6), a partição da deformação produzirá estreitas zonas com componente não-coaxial, e zonas coaxiais de cisalhamento puro triaxial, ou, então, grandes domínios de deformação plana não-coaxial no plano $X_{C} Y_{C}$ horizontal, e domínios estreitos de cisalhamento puro biaxial no plano $Y_{C} Z_{C}$ vertical. Se for considerada deformação descontínua (non-steady-state), alguns domínios podem ser ativos 
durante um curto tempo da deformação, assim como outros podem mudar de comportamento deformacional.

Alguns autores consideram que a partição da deformação é independente da escala, podendo assim ocorrer desde a escala microscópica até continental, ou seja, na escala de um cinturão orogênico (Oldow et al, 1990, Jones \& Tanner, 1995). Além disso, a partição da deformação pode variar no espaço e no tempo. No primeiro caso há uma delimitação de domínios caracterizados por fluxos distintos; no segundo caso pode ocorrer mudanças do fluxo durante a deformação progressiva, em função, por exemplo, de uma deformação descontínua (non-steady ou spinning deformation) (Lister \& Williams 1983, Jiang \& White 1995).

Embora os parâmetros acima discutidos sejam importantes no controle dos diferentes modelos de partição relacionados com deformações naturais, cabe assinalar, no entanto, que os ambientes de convergência ou divergência oblíqua de placas, particularmente na escala orogênica, podem apresentar padrões geométricos e cinemáticos de partição de deformação mais complexos do que os previstos nos trabalhos de modelagem aqui discutidos ou disponíveis na literatura. 


\section{EXTRUSÃO TECTÔNICA E TRANSPORTE LATERAL DE MASSA NA PORÇÃO CENTRAL DO CINTURÃO PARAÍBA DO SUL, SEÇÃO TRÊS RIOS - MATIAS BARBOSA (RJ/MG)}

\subsection{Resumo}

Este trabalho discute a estrutura de uma seção no flanco norte da divergência estrutural do vale do rio Paraíba do Sul no Rio de Janeiro. No centro da estrutura, a foliação milonítica é vertical, a lineação de estiramento é horizontal e os indicadores cinemáticos sugerem movimentação destral (Domínio I). O estiramento vertical é secundário, e o encurtamento ortogonal ao plano de fluxo é evidenciado por estruturas em forma de tabletede-chocolate. Para norte, ocorre um fragmento crustal (lasca tectônica) composto principalmente por ortognaisse (Domínio Paraíba do Sul - Domínio II). Este fragmento sobrepõe-se aos granulitos do Domínio Juiz de Fora (Domínio III). Ocorrem associadas à foliação principal dobras apertadas a isoclinais com eixos subparalelos a lineação de estiramento, além de dobras com superfície axial íngreme subparalelas às zonas de cisalhamento transpressivas e eixos paralelos à lineação de estiramento, que deformam a foliação milonítica. São encontrados tectonitos $L$ e mullions subparalelos às charneiras dos dois grupos de dobras. No Domínio II, a foliação principal delineia em estereograma uma guirlanda com eixo de caimento baixo para NE, que é subparalelo a concentração da lineação de estiramento. Os indicadores cinemáticos sugerem movimento de topo para WSW, subparalelos e oblíquos ao cinturão Paraíba do Sul. A foliação e a lineação de estiramento apresentam orientação semelhante nos domínios II e III. Nos granulitos, estas estruturas obliteram a estruturação anterior. São registradas estruturas tardias, como zonas de cisalhamento dúcteis-rúpteis inversas com movimentação de topo para NW, e zonas de cisalhamento dúcteis transtrativas, sinistrais. A evolução estrutural (principal e tardia) da área é interpretada em termos de uma transpressão não-confinada. A partição da deformação durante convergência oblíqua e extrusão tectônica poderia explicar a simultaneidade entre os movimentos paralelos ao cinturão e os empurrões destrais para NW. A extrusão tectônica poderia explicar também a geração de tectonitos $L$ e a ausência de lineações verticais nas zonas de cisalhamento transpressivas do cinturão. 


\section{EXTRUSÃO TECTÔNICA DE GRANULITOS NA PORÇÃO CENTRAL DA PROVÍNCIA MANTIQUEIRA, SEÇÃO BARRA DO PIRAÍ - CONSERVATÓRIA, RJ.}

\subsection{Resumo}

O presente trabalho trata da análise estrutural de uma seção entre Barra do Piraí e Conservatória, porção SW do Estado do Rio de Janeiro. A seção estudada situa-se na aba norte da estrutura divergente da Zona de Cisalhamento do Rio Paraíba do Sul, segmento central da Província Mantiqueira. Engloba rochas gnáissicas e granulíticas milonitizadas, correspondentes às unidades Paraíba do Sul, Quirino e Juiz de Fora. Foram reconhecidos cinco domínios estruturais ( a V), todos com foliação na direção NE-SW. O domínio estrutural I é marcado por uma foliação vertical e lineação direcional. O domínio II apresenta foliação com caimento baixo a moderado para NW e lineação predominantemente de mergulho, seguido pelos domínios III e IV, marcados, respectivamente, por uma foliação subvertical e lineação subhorizontal, e foliação de baixo ângulo de mergulho para SE e lineação oblíqua para sul. O domínio estrutural V é semelhante aos domínios I e III, sendo porém comum a ocorrência de dobras com eixos e planos axiais paralelos à foliação e lineação. Os indicadores cinemáticos nos domínios I, III e V são compatíveis com movimento destral e, no domínio IV, com movimento de topo para norte. Em todos os domínios observam-se estruturas contracionais coexistentes com as estruturas tipicamente transcorrentes. A evolução estrutural da área é interpretada como resultante de deformação em regime transpressivo não-confinado, com movimentação regional destral e extrusão localizada associada à partição espacial e temporal da deformação. 


\section{ORIENTAÇÃO PREFERENCIAL DE RETÍCULO CRISTALINO DO QUARTZO}

\subsection{Introdução}

O quartzo $\left(\mathrm{SiO}_{2}\right)$ é um mineral da classe dos tectossilicatos, que são formados por tetraedros de $\mathrm{SiO}_{4}$ com máxima polimerização, ligados espacialmente entre si pelos seus vértices. Os polimorfos mais comuns são a tridimita, cristobalita e coesita. A simetria do quartzo- $\alpha$ apresenta uma simetria romboédrica, enquanto seu equivalente de alta temperatura, quartzo- $\beta$, apresenta uma estrutura de simetria hexagonal. $O$ campo de estabilidade dos polimorfos de $\mathrm{SiO}_{2}$ é mostrado na figura 5.1 .

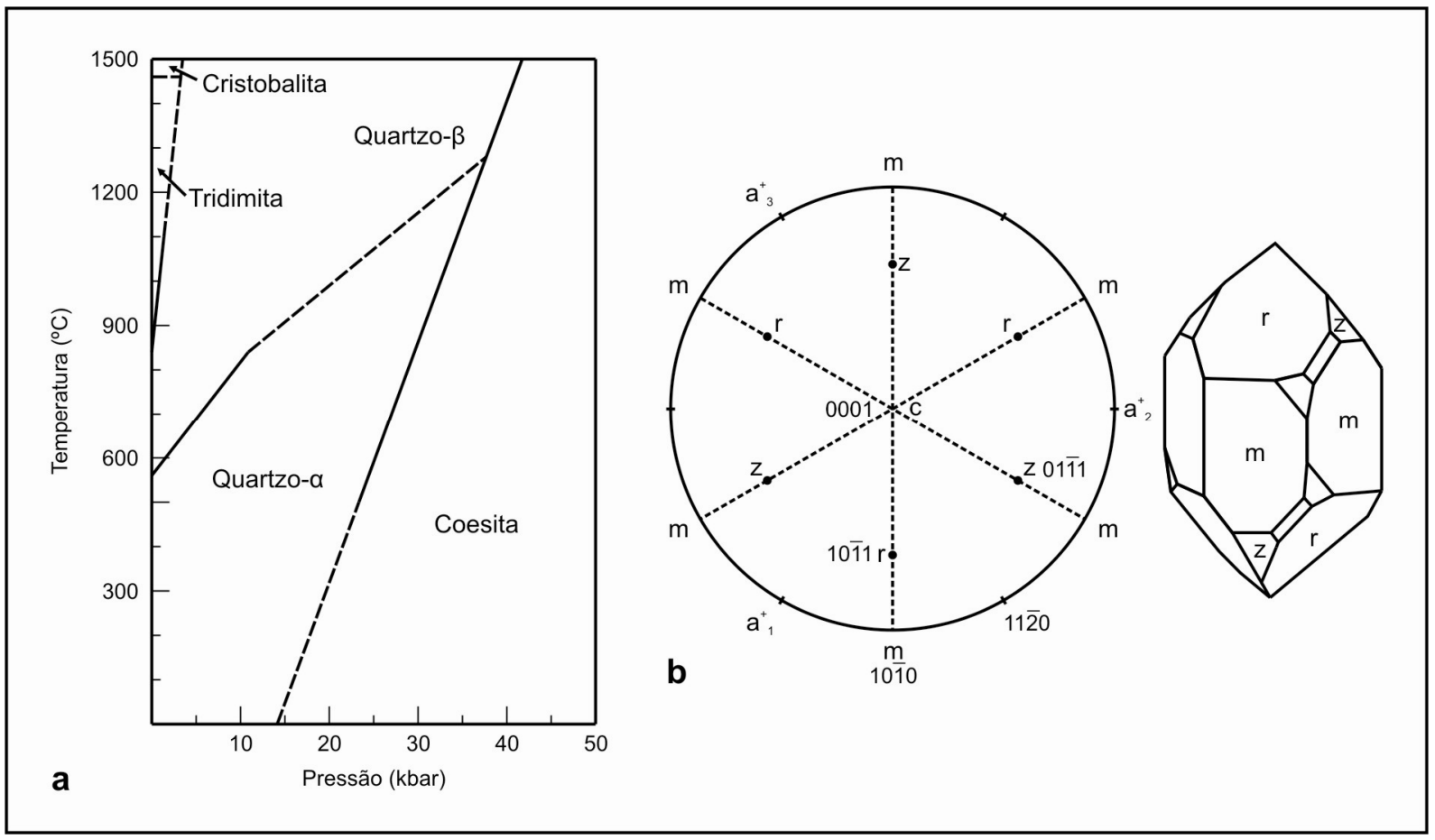

Figura 5.1 - a) diagrama PXT de transformação de fases do $\mathrm{SiO}_{2}$; b) cristalografia do quartzo-a (Klein \& Hurlbut 1999).

A deformação no quartzo é controlada por vários fatores, tais como a taxa de deformação, esforço diferencial, conteúdo de água no sistema e temperatura. Uma das principais conseqüências da interação desses fatores é a formação de uma orientação preferencial do retículo cristalino (OPR) desse mineral. Esta orientação é formada principalmente pelo deslizamento de discordâncias, a qual muda a forma do grão e sua interação com os cristais vizinhos. A geminação mecânica pode ter um efeito semelhante. Normalmente, pode operar mais de um sistema de deslizamento. Além dos sistemas de deslizamentos ativos, o tipo de deformação e a simetria da deformação finita também influenciam no tipo de OPR que será desenvolvida. 


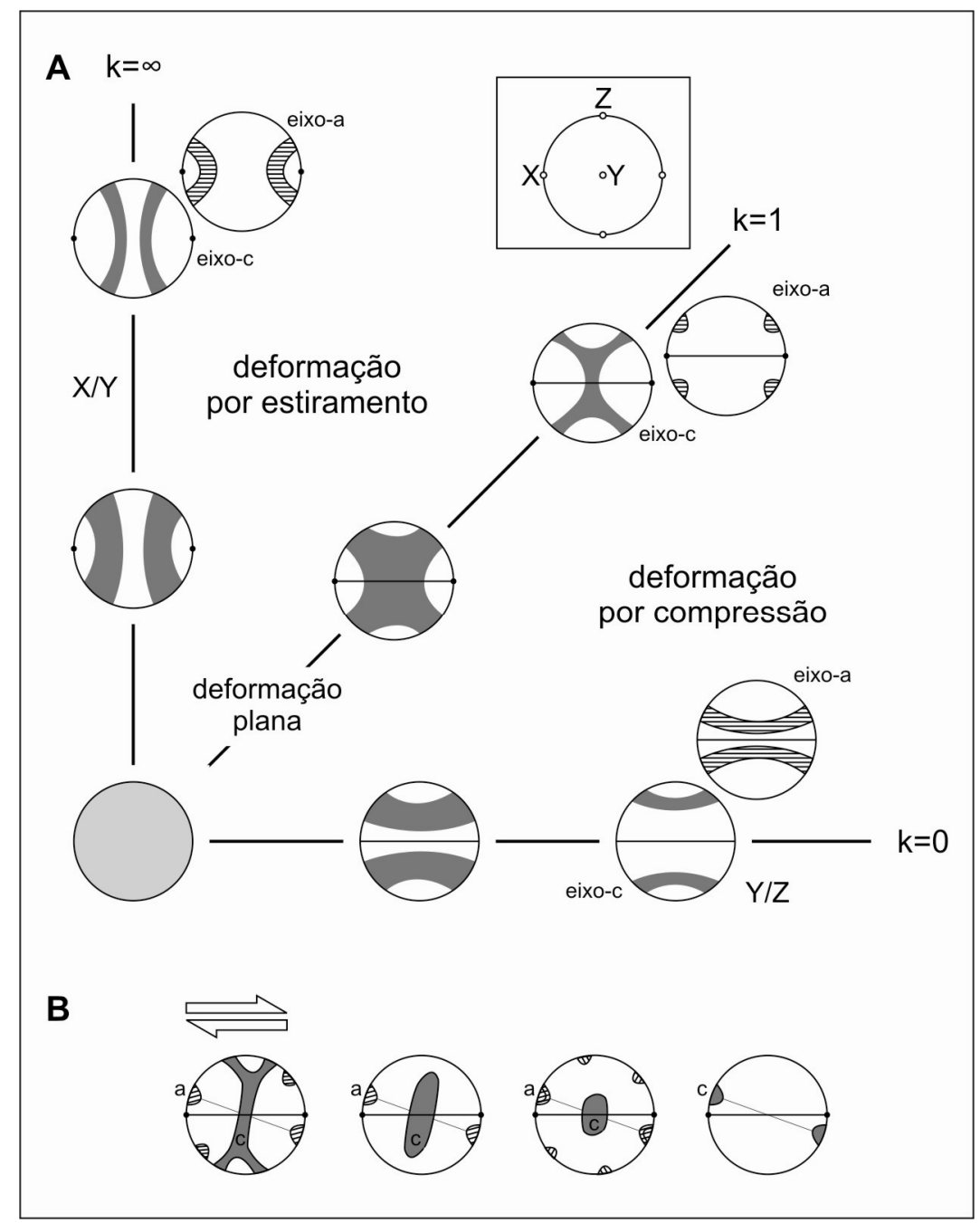

Figura 5.2 - a) diagrama de Flinn mostrando os padrões de distribuição de eixos $\langle c\rangle$ e $\langle a\rangle$ do quartzo para deformação progressiva coaxial. b) diagramas mostrando quatro tipos de orientação preferencial do retículo cristalino (OPR) de eixos $\langle C\rangle$ e $\langle a\rangle$ do quartzo, desenvolvidas durante deformação progressiva não-coaxial (Passchier \& Trouw 1996).

Entre temperaturas de $300^{\circ}$ e $400^{\circ} \mathrm{C}$ ocorre principalmente deslizamento segundo $\mathrm{O}$ sistema (c)<a>. Extinção ondulante e deformação lamelar são típicas de deformação nessas condições de temperatura, e são formadas principalmente por recristalização dinâmica por "bulging" (Stipp et al. 2002). Entre temperaturas de 400 e 500ํㅡ, o deslizamento prismático $\{m\}<a>$ torna-se importante e o mecanismo de recristalização dinâmica dominante é a rotação de subgrãos. Entre $500^{\circ}$ e $700^{\circ} \mathrm{C}$, a recristalização dinâmica se dá principalmente por migração de borda de grãos, onde os limites dos grãos se tornam lobados e são comuns microestruturas tipo "pinning" (Stipp et al. 2002). Acima de $700^{\circ} \mathrm{C}$, ocorre a ativação do sistema prismático $\{\mathrm{m}\}<\mathrm{C}>$ (Mainprice et al. 1986). O deslizamento prismático pode também ser acompanhado por deslizamento nos planos romboédricos. 
A influência da presença de água no retículo cristalino do quartzo é uma questão ainda não muito bem compreendida. Porém, há indicações de que o aumento da quantidade de água contribui para diminuir a resistência do cristal.

O principal tipo de geminação mecânica que pôde ser detectado pela técnica utilizada é a geminação de Dauphiné. Esta geminação consiste em uma rotação de $180^{\circ}$ ao redor do eixo <c>, não podendo, assim, ser observada opticamente, já que os eixos <c> permanecem paralelos. Ela pode ocorrer durante o crescimento (por exemplo, na transição entre quartzo- $\alpha$ e quartzo- $\beta$ ) ou durante a deformação. Existem estudos experimentais que mostram que geminação de Dauphiné é ativada por esforço diferencial alinha os pólos dos planos romboédricos positivos $\{r\}$ com o eixo de compressão.

O efeito da recristalização estática sobre a evolução das OPR é mais difícil de avaliar, pois a microestrutura da deformação pode ser totalmente obliterada pelo mecanismo da diminuição da borda do grão. Entretanto, os experimentos de Heilbronner \& Tullis (2002) mostram que a OPR preexistente não sofre modificação significativa, enquanto os experimentos realizados por Green et al. (1970) sugerem que a manutenção de temperaturas elevadas, mesmo depois da deformação, gerou resultados diferentes para diferentes tipos de fábricas preexistentes. Green (1967) mostra uma concentração preferencial de eixos-c próxima ao eixo de compressão produzido pelo "annealing".

Os tipos de OPR dos eixos-c e dos eixos-a do quartzo são esquematizados na figura 5.2. Essas variações são produzidas em função da diferença do grau de metamorfismo e do tipo de deformação imposto, e são diretamente correlacionadas com a evolução dos principais sistemas de deslizamento no quartzo.

\subsection{As OPR medidas}

As amostras de quartzo, cujas orientações cristalográficas foram medidas, foram selecionadas de modo que fossem representativas dos diferentes domínios estruturais caracterizados ao longo da seção estudada.

As amostras STX 09, STX 23 e STX 45 correspondem respectivamente aos domínios I, II e III da seção geológica realizada entre as cidades de Três Rios (RJ) e Matias Barbosa (MG). As amostras STX 245, STX 285 e STX 287 foram coletadas ao longo do perfil entre Barra do Piraí e Conservatória (RJ), e são relativas aos domínios III, IV e V, respectivamente. Os domínios I e II não forneceram amostras adequadas para a análise EBSD. 


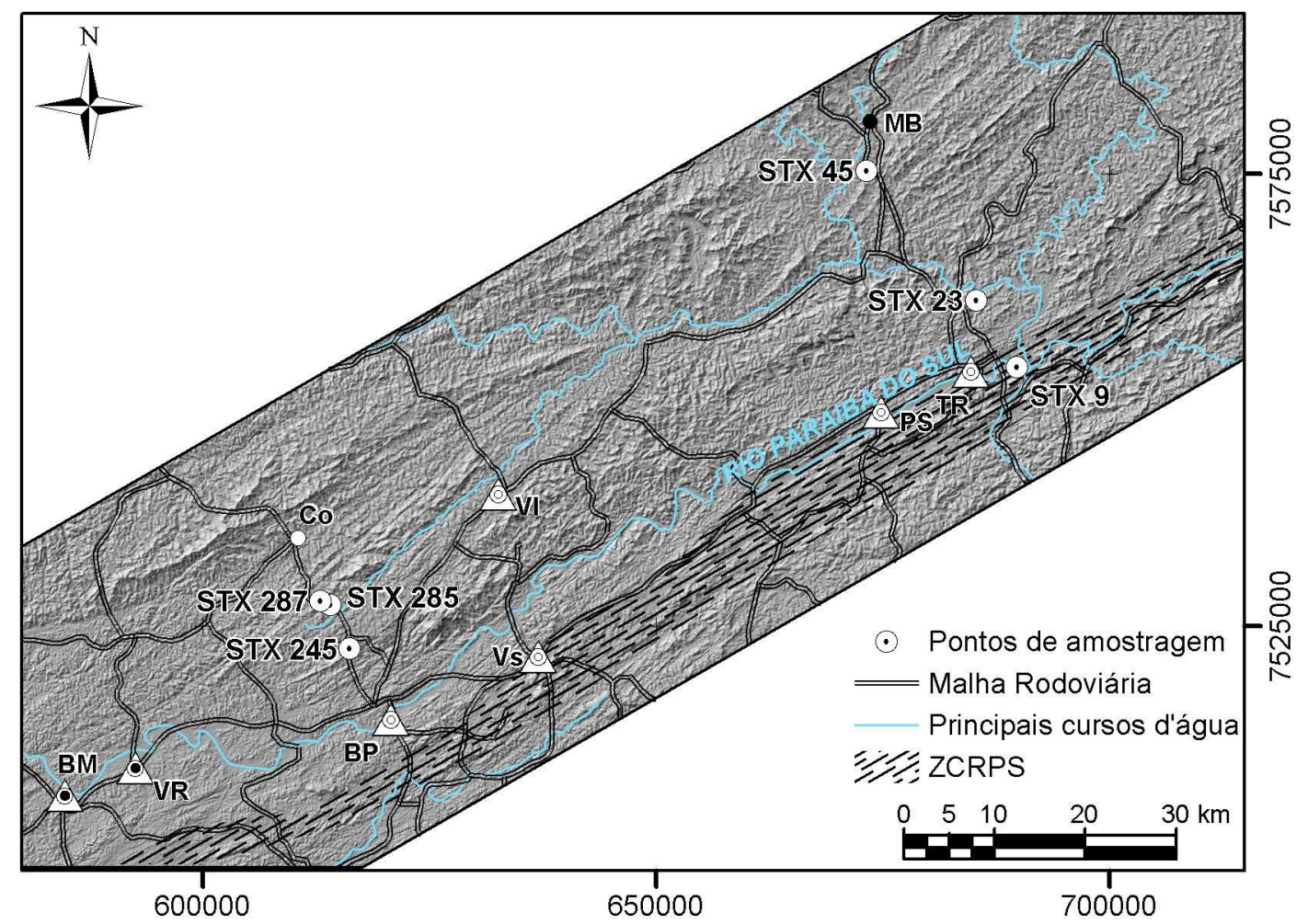

Figura 5.3 - Imagem de relevo sombreado (Miranda \& Coutinho 2005) com a localização das amostras e a Zona de Cisalhamento do Rio Paraíba do Sul.

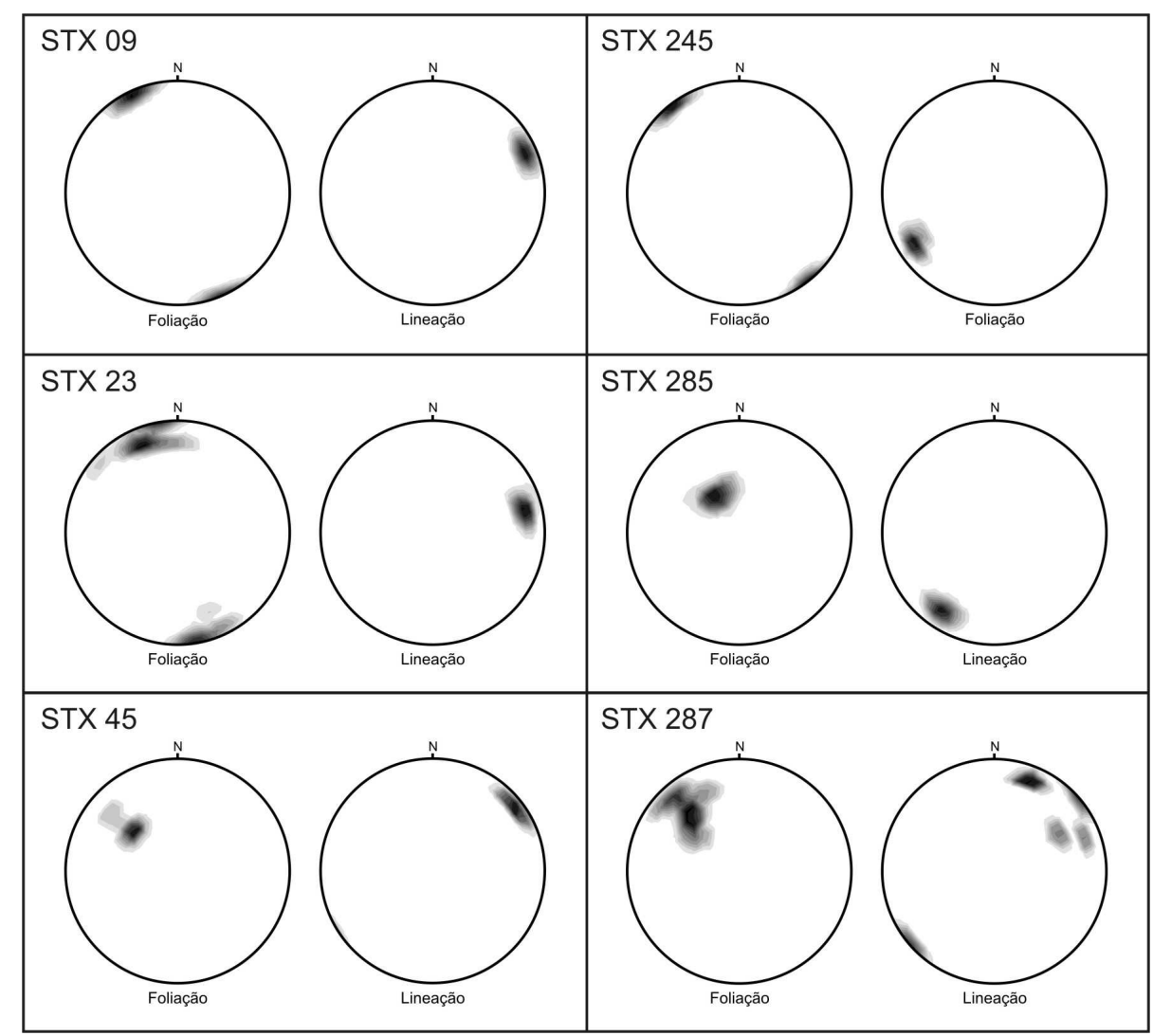

Figura 5.4 - Diagramas de projeção estereográfica contendo os dados de foliação e lineação para as amostras nas quais foram medidas as orientações preferenciais da rede cristalográfica do quartzo. 
A localização das amostras e a sua distância em relação à Zona de Cisalhamento do Rio Paraíba do Sul é mostrada na figura 5.3. Os dados estruturais de foliação e lineação extraídos dos pontos específicos estão esquematizados na figura 5.4.

\section{$\underline{\text { Amostra STX09 }}$}

A amostra STX 09 (figuras 5.6A e B e 5.7A e B) é composta por quartzo (35\%), plagioclásio (30\%), anfibólio (15\%), biotita (10\%) e minerais opacos (5\%). Apresenta foliação fortemente milonítica e bandamento composicional bem marcado. Sua estruturação geral é dada principalmente por orientação de ribbons de quartzo e, secundariamente, por cristais de biotita e agregados de anfibólio.

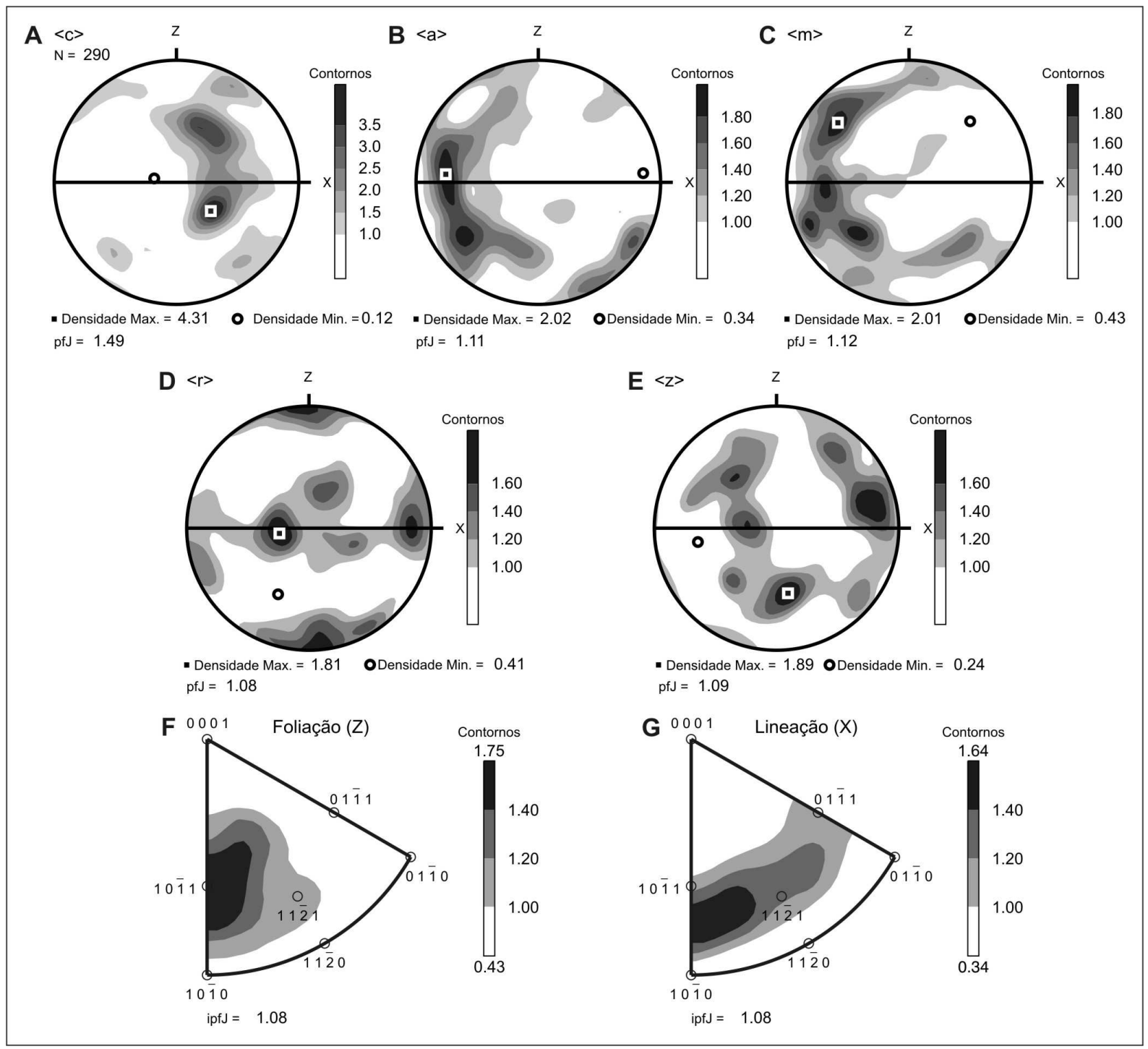

Figura 5.5 - OPR do quartzo para a amostra STX 09 apresentada em figuras de pólo direta e inversa. Os contornos estão indicados ao lado das figuras, onde $N$ é o número de medidas. Para as figuras de pólo diretas, a foliação é vertical, E-W, e a lineação é horizontal, também E-W. 

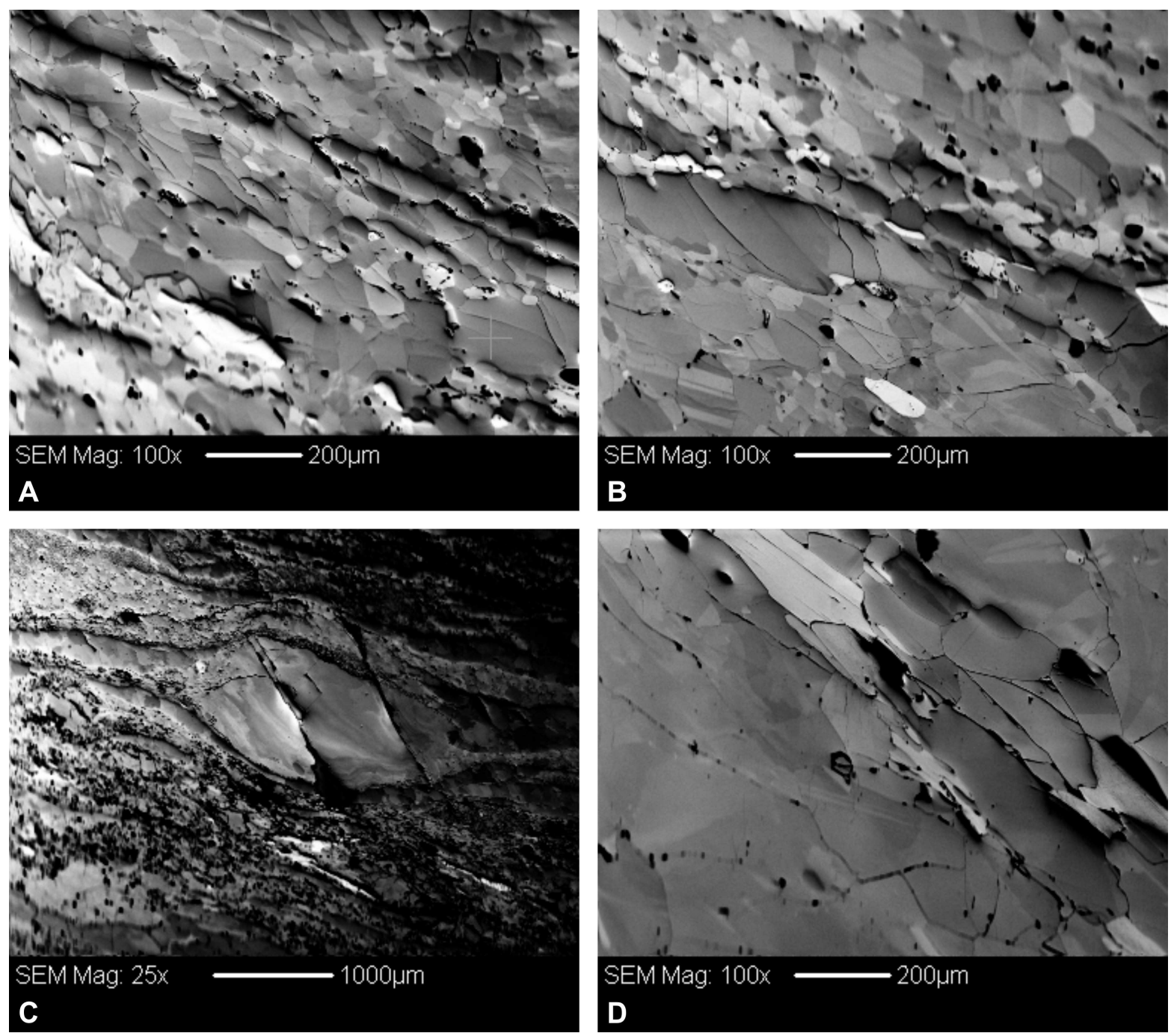

Figura 5.6 - Imagens SEM ("scanning electron microscope") das amostras analisadas. A e B) espécime STX 09; C) espécime STX 45; D) STX 245.

Em seção delgada (figura 5.7), observa-se uma matriz quartzo-feldspática poligonizada, que constitui aproximadamente $45 \%$ da lâmina. Essa matriz, fortemente recristalizada, não se mostra com orientação preferencial ou com deformação intracristalina aparentes. Apresenta granulação bimodal (entre 50 a $200 \mu \mathrm{m}$ ). Os ribbons de quartzo perfazem cerca de $35 \%$ da amostra, e possuem granulação de cerca de $1,5 \mathrm{~mm}$. Apresentam contatos retos com a matriz e interlobados entre eles, sendo raras as texturas de deformação intracristalina, como extinção ondulante e contatos entre subgrãos. $\mathrm{Na}$ amostra é também marcante a presença de porfiroclastos de plagioclásio (tamanho de até 1 $\mathrm{cm})$, sendo notáveis estruturas do tipo manto-núcleo e extinção ondulante.

A OPR medida na amostra STX09 (figura 5.5) é caracterizada por duas concentrações de eixos $<c>$ simetricamente localizadas entre os eixos $Y$ e $Z$. As concentrações máximas se encontram a $20^{\circ}$ e $40^{\circ}$ do eixo $\mathrm{Y}$, conectadas por concentrações menores ao seu redor, 
caracterizando um padrão intermediário entre guirlanda simples e ponto máximo paralelo ao eixo intermediário de deformação.
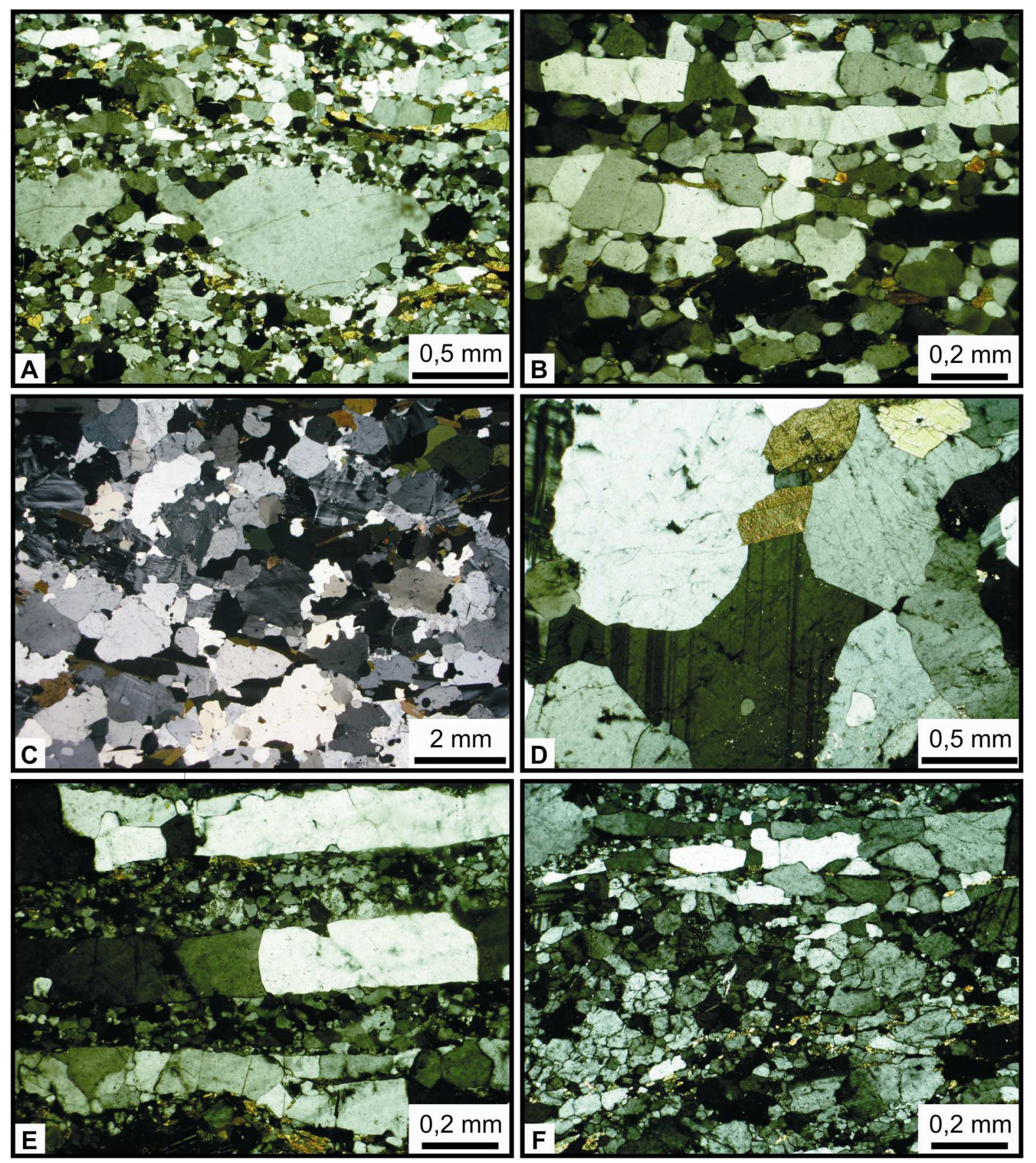

Figura 5.7 - Fotomicrografias das amostras estudadas. A e B - STX 09; C e D-STX 23; E e FSTX 45.

Os pólos dos planos prismáticos $\{a\}$ e $\{m\}$ apresentam concentrações máximas principais próximas à lineação, e são ortogonais à guirlanda de eixos $<\mathrm{c}>$, fazendo um ângulo de aproximadamente $40^{\circ} \mathrm{com}$ a mesma. Essa OPR é marcada por um padrão dos pólos dos planos romboédricos superiores $\{r\}$ muito característico: apresenta uma 
distribuição de concentrações ao longo do plano XY, com máximo paralelo ao eixo $Y$, e um máximo secundário paralelo a Z . A figura relativa ao plano romboédrico inferior $\{z\}$ não mostra relação simples com a foliação e a lineação.

As figuras de pólos inversas mostram a importância do plano $\{r\}$ e sua relação com a foliação e a lineação. A lineação $X$ e o pólo do plano da foliação $Z$ concentram-se, preferencialmente próximos a $<r>$.

\section{$\underline{\text { Amostra STX } 23}$}

A amostra STX23 (figura 5.7C e D) é constituída basicamente por quartzo (30\%), plagioclásio (20\%), feldspato alcalino (25\%), biotita (10\%) e anfibólio (15\%), com foliação gnáissica dada pela orientação dos cristais de biotita e agregados de anfibólio. Em seção delgada (figura 5), observa-se granulação seriada entre $250 \mu \mathrm{m}$ e $4 \mathrm{~mm}$ e contatos fortemente interlobados entre os grãos, sugerindo uma intensa atuação de migração de borda de grãos durante a recristalização dinâmica. É marcante, também, a presença de feições de deformação intracristalina como extinção ondulante e limites de subgrãos, principalmente nos cristais de quartzo e plagioclásio, e geminação de deformação nos grãos de plagioclásio.

Em relação à OPR medida (figura 5.8), pode-se observar que o padrão de eixos $<\mathrm{c}>$ da amostra STX 23 apresenta-se difuso, porém se assemelha a uma guirlanda cruzada tipoII, com importante contribuição de eixos dispostos assimetricamente ao longo do plano XY.

A figura de pólos para os eixos <a> mostra três concentrações principais dispostas no plano XZ, com a concentração principal a $25^{\circ}$ da lineação. De maneira semelhante, as máximas concentrações dos pólos aos planos $\{m\}$ estão também posicionadas no plano $X Z$, mas a concentração máxima forma um ângulo de 15ํㅜ com o eixo $Z$.

Finalmente, a figura 5.8D exibe uma distribuição de eixos $<r>$ em dois máximos nas bordas do estereograma, que são intermediários aos eixos $\mathrm{X}$ e Z, e um máximo paralelo ao eixo Y. A figura relativa ao plano romboédrico inferior $\{z\}$ não mostra relação simples com a foliação e a lineação. As figuras de pólo inversas evidenciam um maior paralelismo da normal à foliação com os eixos <a>, e da lineação com os eixos <z>, apesar de não ter sido observado nenhum padrão definido no diagrama de pólo relativo a esse eixo. 


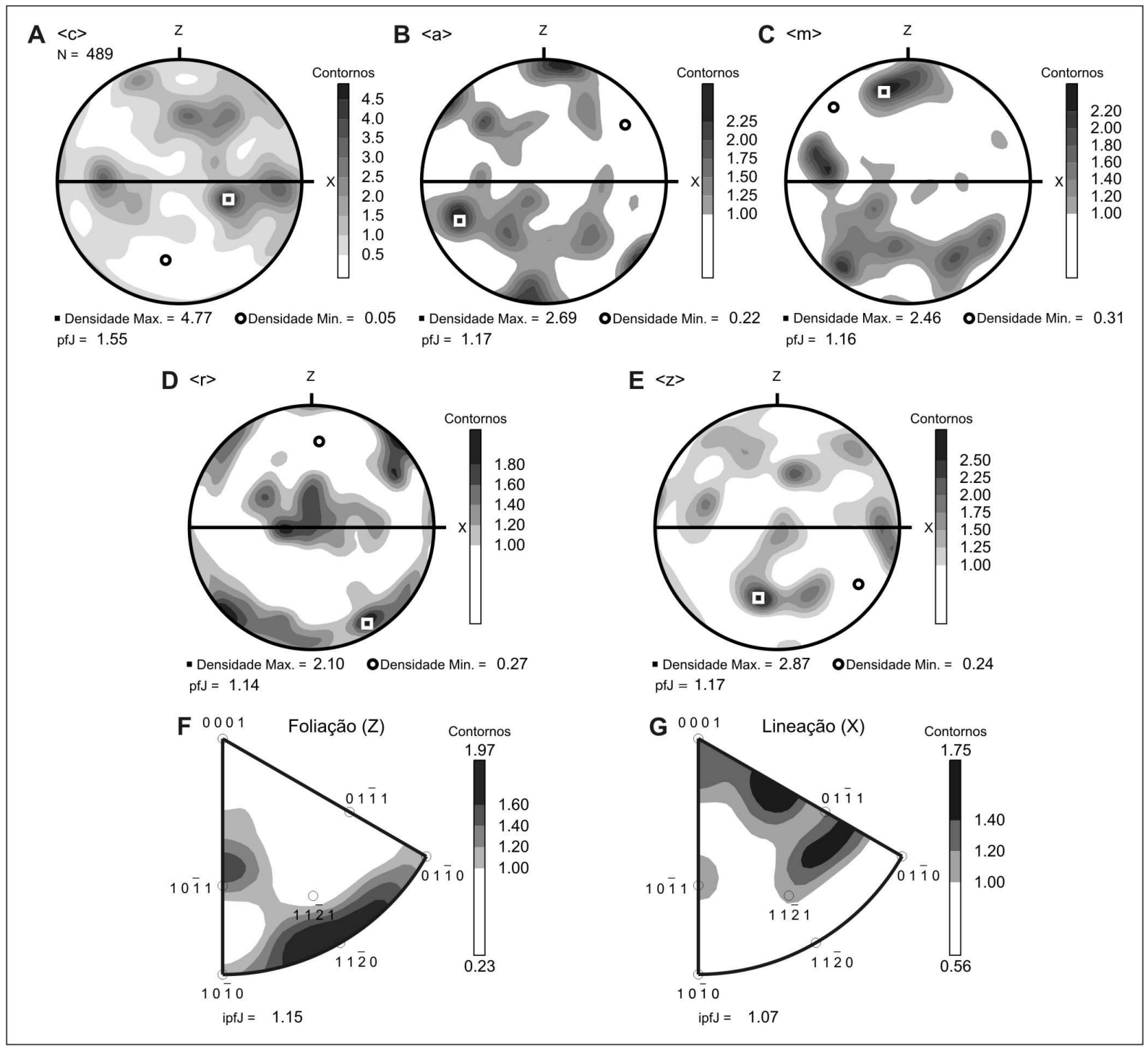

Figura 5.8 - OPR do quartzo para a amostra STX 23 apresentada em figuras de pólo diretas e inversas. As curvas de contorno estão indicadas ao lado das figuras, onde $N$ é o número de medidas. Para as figuras de pólo diretas, a foliação é vertical, E-W, e a lineação é horizontal, E-W.

\section{$\underline{\text { Amostra STX } 45}$}

A amostra STX 45 (figuras 5.6C e 5.7E e F) é composta essencialmente por quartzo $(40 \%)$, plagioclásio (35\%) e biotita $(25 \%)$, com foliação milonítica dada pela orientação de ribbons de quartzo e pela orientação dos cristais de biotita. Em seção delgada observa-se uma matriz quartzo-feldspática, poligonizada, de granulometria seriada entre $25 \mu \mathrm{m}$ e 0,5 $\mathrm{mm}$. Essa matriz corresponde a cerca de $50 \%$ da amostra, e ocorre intercalada com ribbons de quartzo ( 30\%) com granulometria entre 0,15 e $0,5 \mathrm{~mm}$. Os ribbons apresentam porções recristalizadas e, localmente, feições de deformação intracristalina, como extinção ondulante e limite de subgrãos, porém a grande maioria possui extinção homogênea. A amostra apresenta também porfiroclastos de plagioclásio ( 20\%) de até $4 \mathrm{~mm}$ com forte ocorrência 
de extinção ondulante, assinalada principalmente por geminação curvada. Estes porfiroclastos possuem localmente bandas de deformação em seu interior, com novos grãos exibindo grande contraste de granulação com a do cristal antigo.

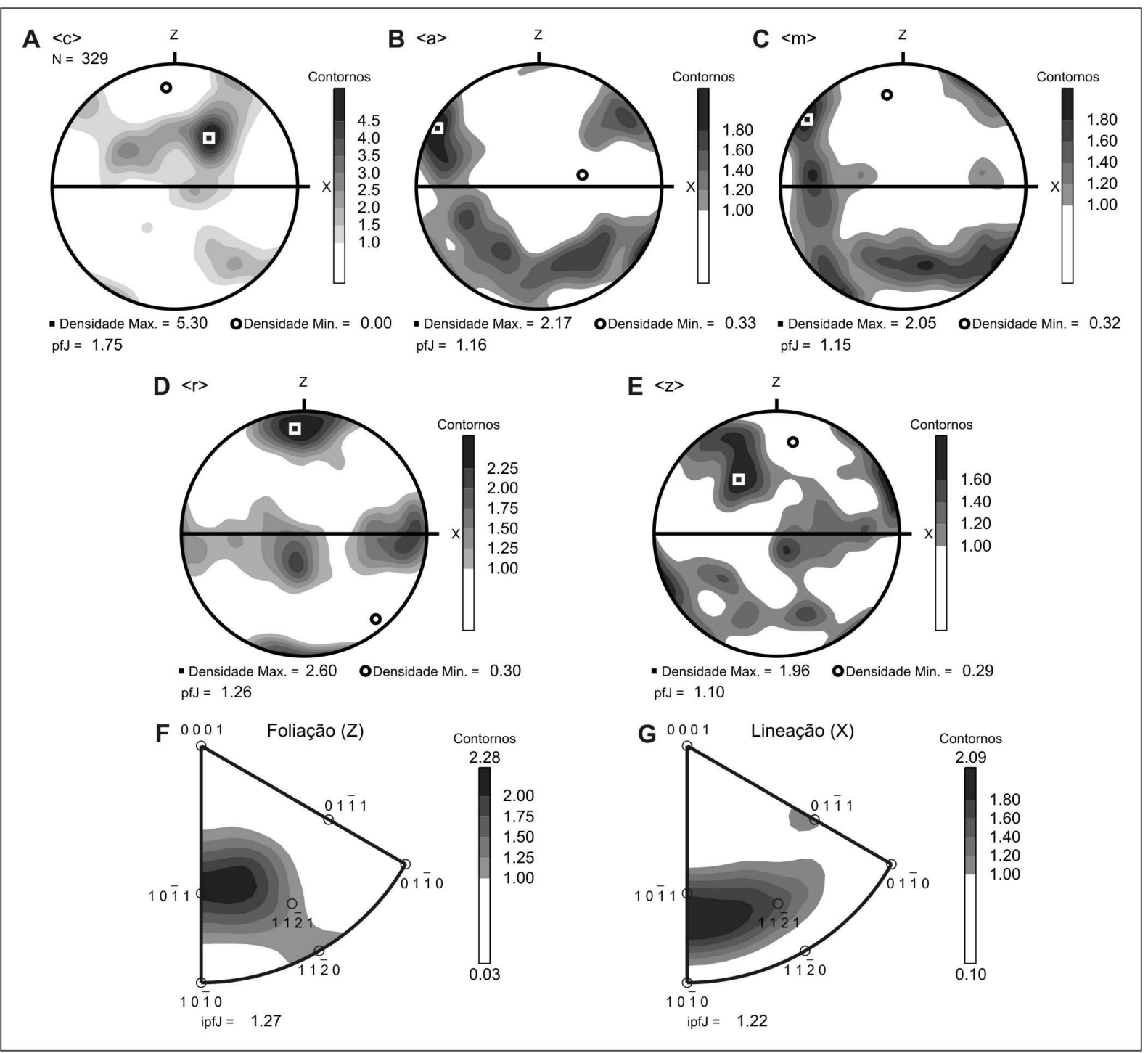

Figura 5.9 - OPR do quartzo para a amostra STX 45 apresentada em figuras de pólo diretas e inversas. As curvas de contorno estão indicadas ao lado das figuras, onde $N$ é o número de medidas. Para as figuras de pólo diretas, a foliação é vertical, E-W, e a lineação é horizontal, E-W.

A OPR medida na amostra STX 45 (figura 5.9) exibe uma guirlanda com um padrão de eixos $<\mathrm{C}>$ intermediário entre guirlanda em pequeno círculo e guirlanda cruzada tipo I, descrito por Schmidt \& Casey (1986), com concentração máxima intermediária aos três eixos de referência, situando-se no quadrante NE do estereograma. A distribuição dos eixos $<$ a $>$ e $<$ m se dá ao longo de uma guirlanda de grande círculo que tangencia a borda do diagrama, com concentração máxima situada a $30^{\circ}$ de X. 
Essa OPR exibe um padrão dos pólos ao plano romboédrico superior $\{r\}$ semelhante ao descrito para a amostra STX 09: apresenta um máximo de concentração paralela ao eixo Z, e uma distribuição em guirlanda de círculo máximo paralela ao plano da foliação. O gráfico de eixos-z mostra-se difuso, porém há uma aproximação da existência de uma guirlanda central orientada a $30^{\circ}$ do eixo de referência $Z$, com convergência máxima de pontos no quadrante NW do estereograma, e dois máximos secundários a $20^{\circ}$ do eixo X.

As figuras de pólo inversas refletem o padrão já observado na figura 5.9D, mostrando a importância do paralelismo da normal à foliação e da lineação com os pólos dos planos romboédricos superiores.
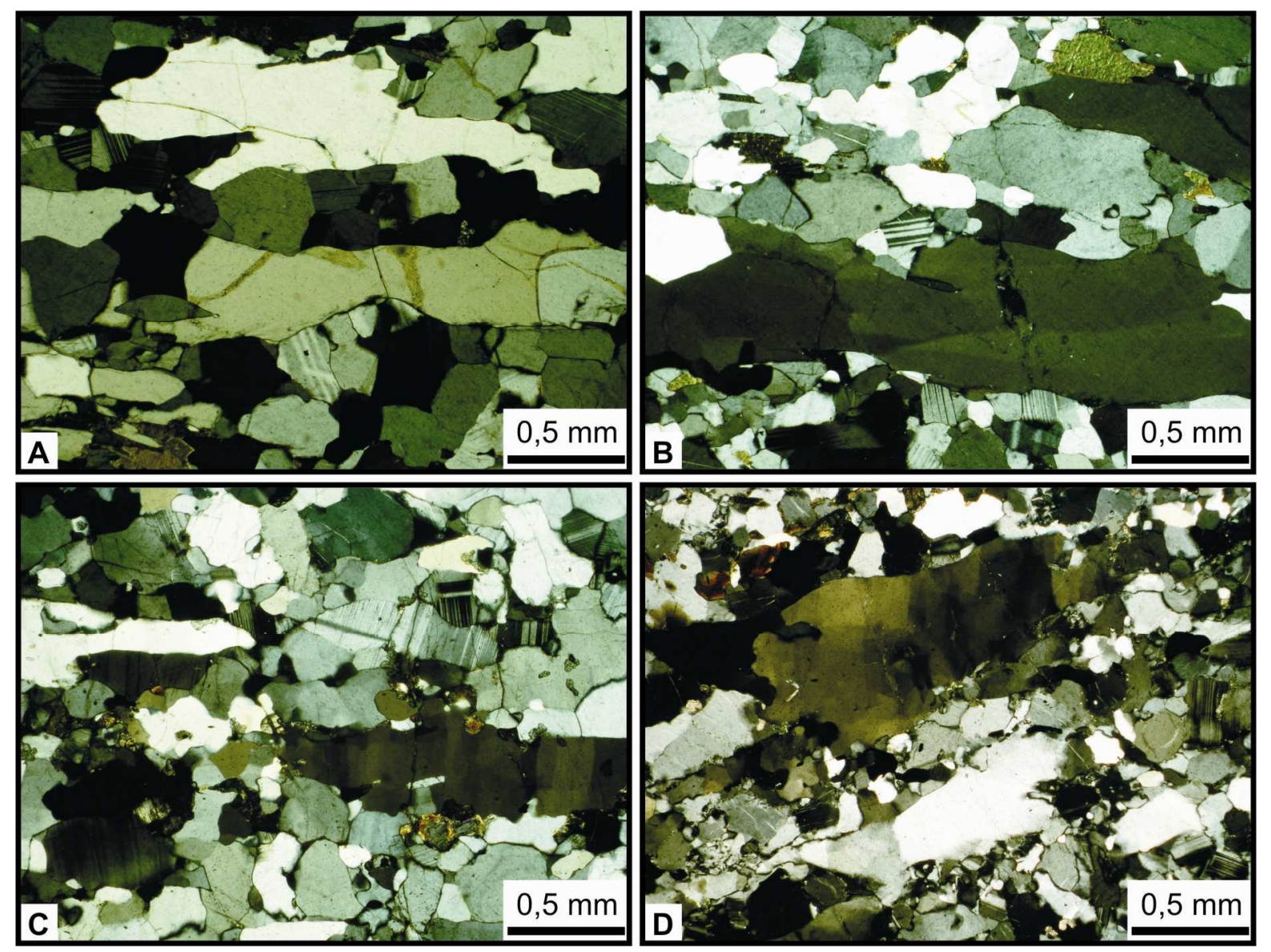

Figura 5.10 - Fotomicrografias das amostras estudadas. A e B - STX 245; C - STX 285; D - STX 287.

\section{Amostra STX 245}

Essa amostra (figuras 5.6D e 5.10A e B), constituída por quartzo (40\%), plagioclásio (40\%), biotita (15\%) e anfibólio (5\%), apresenta bandamento composicional fino $(<1 \mathrm{~cm})$ e foliação milonítica. Em lâmina, nota-se a presença de uma matriz (65\%), em geral poligonizada, com contato entre os grãos localmente interlobado, porém sem orientação 
preferencial, e tamanho de grãos ao redor de 0,25 mm. Os ribbons de quartzo (20\%) estão em contato irregular com a matriz e, localmente, têm limites de subgrãos paralelos aos limites do cristal. A amostra exibe porfiroclastos de plagioclásio, que chegam até $2 \mathrm{~mm}$, com estruturas notáveis do tipo manto-núcleo e extinção ondulante.

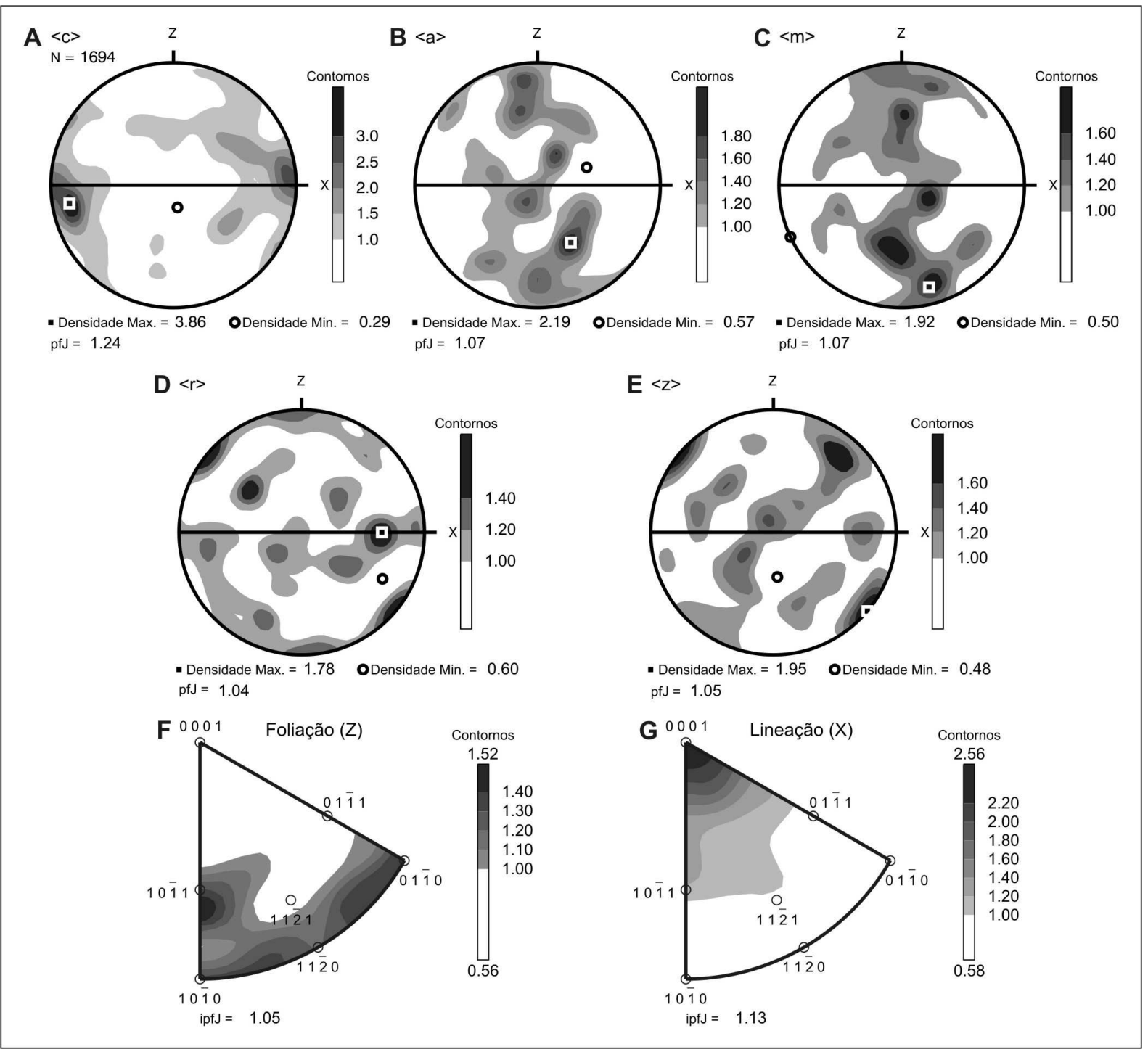

Figura 5.11 - OPR do quartzo para a amostra STX 245 apresentada em figuras de pólo diretas e inversas. As curvas de contorno estão indicadas ao lado das figuras, onde $N$ é o número de medidas. Para as figuras de pólo diretas, a foliação é vertical, E-W, e a lineação é horizontal, E-W.

O padrão de OPR observado na amostra (figura 5.11) é caracterizado por dois

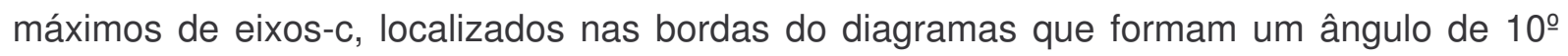
com a lineação. Os eixos<a > exibem uma distribuição em guirlanda perpendicular aos eixosc, com concentrações que podem ser divididas em três máximos principais, fazendo entre si um ângulo de 60․ Os pólos dos planos de primeira ordem, apesar de um pouco dispersos, 
distribuem-se também ao longo de uma guirlanda, no centro do estereograma, segundo o plano YZ.

A figura relativa aos eixos $<r>$, revela uma distribuição mal definida, com concentração

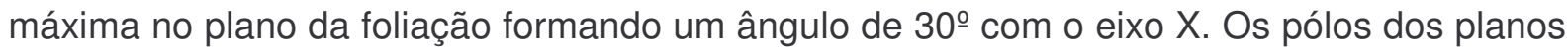
romboédricos negativos exibem concentração máxima de pontos na periferia do diagrama, formando um ângulo de 40ํㅡㄹ a lineação, e um máximo secundário ortogonal a este, bem como um terceiro máximo com certa dispersão ao redor do eixo $\mathrm{Y}$.

Nas figuras de pólo inversas nota-se o paralelismo da lineação com os eixos $<\mathrm{C}>$, e a normal à foliação situada entre os eixos $<$ a $>$ e $<m>$, e uma concentração próxima ao eixo $<\mathrm{r}>$.

\section{Amostra STX 285}

A amostra STX 285 (figura 5.10C) é constituída principalmente por quartzo (50\%) e plagioclásio $(30 \%)$, ortopiroxênio $(15 \%)$ e biotita $(5 \%)$, com uma foliação milonítica bem pronunciada. Em seção delgada observa-se uma matriz quartzo-feldspática equigranular (0,25 a 0,5 mm), sem orientação preferencial, que corresponde a cerca de $90 \%$ da amostra. O contato entre os grãos é levemente interlobado, havendo domínios com textura poligonizada. Em meio a matriz, ocorrem ribbons de quartzo isolados (10\%), com tamanho de até $1,5 \mathrm{~mm}$, em contatos retilíneos com a matriz, apresentando feições de deformação intracristalina como limites de subgrãos que, em alguns cristais, se assemelha ao padrão de extinção em forma de tabuleiro de xadrez.

A OPR medida apresenta relação complexa entre a distribuição dos eixos cristalográficos e os eixos de referência $X, Y$ e Z (figura 5.12). A concentração máxima de eixos $<\mathrm{c}>$ localiza-se aos três eixos de referência, no quadrante NE do gráfico. Os eixos <a> possuem concentração máxima no quadrante $S E$, enquanto os eixos $<m>$ têm convergência máxima ao longo do plano da foliação, formando um ângulo de $45^{\circ} \mathrm{com}$ a lineação, bem como dois máximos secundários entre os eixos $\mathrm{X}, \mathrm{Y}$ e $\mathrm{Z}$, que são simétricos ao plano da foliação. Os eixos <r> estão distribuídos em vários pontos máximos no estereograma, com concentração principal paralela ao eixo $\mathrm{Y}$, e as demais localizadas nos limites do diagrama. Já os eixos <Z> estão dispersos por todo diagrama, com concentração máxima ao longo do plano $\mathrm{YZ}$ e formando um ângulo de $30^{\circ}$ com o eixo $\mathrm{Z}$.

As figuras de pólo inversas exprimem essa mesma relação complexa entre os eixos, com concentração máxima localizada no centro dos diagramas. 


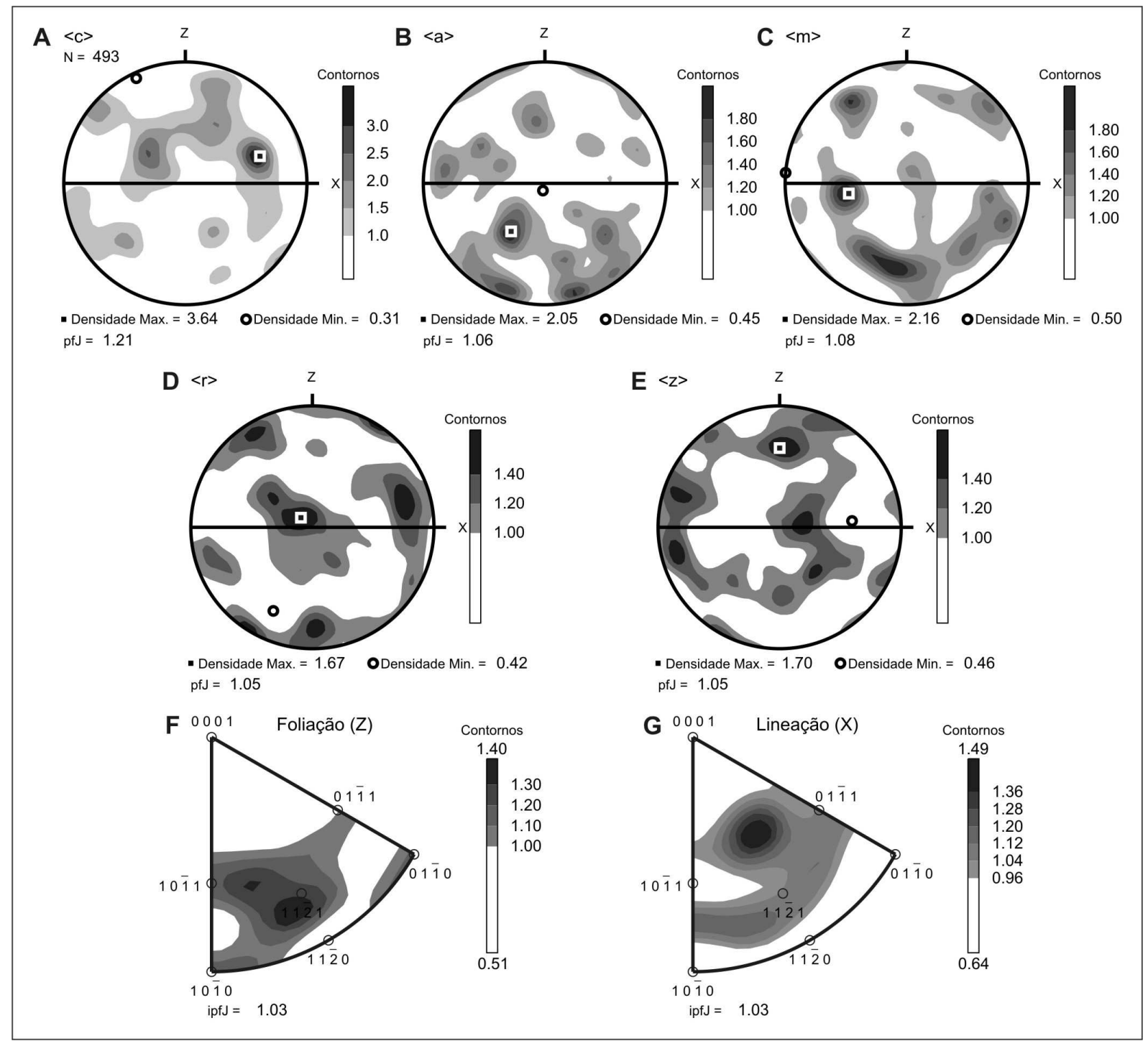

Figura 5.12 - OPR do quartzo para a amostra STX 285 apresentada em figuras de pólo diretas e inversas. As curvas de contorno estão indicadas ao lado das figuras, onde $N$ é o número de medidas. Para as figuras de pólo diretas, a foliação é vertical, E-W, e a lineação é horizontal, E-W.

\section{Amostra STX 287}

A amostra STX 287 (figura 5.10D) é composta essencialmente por quartzo (35\%), plagioclásio (30\%) e biotita (15\%), anfibólio (15\%) e clinopiroxênio (5\%), com foliação milonítica dada pela orientação de ribbons de quartzo, cristais de biotita e agregados de anfibólio e piroxênio. Em seção delgada observa-se um bandamento composicional com cerca de $7 \mathrm{~mm}$ de espessura, caracterizado por uma granulação mais grossa, havendo no entanto bandas mais ricas em minerais máficos de granulação mais fina. A matriz é de composição quartzo-feldspática e apresenta contatos interlobados e também retilíneos. Os ribbons de quartzo estão em contato irregular com a matriz e apresentam-se muito 
deformados e com limites de subgrãos interdigitados, exibindo deformação semelhante ao padrão em forma de tabuleiro de xadrez.

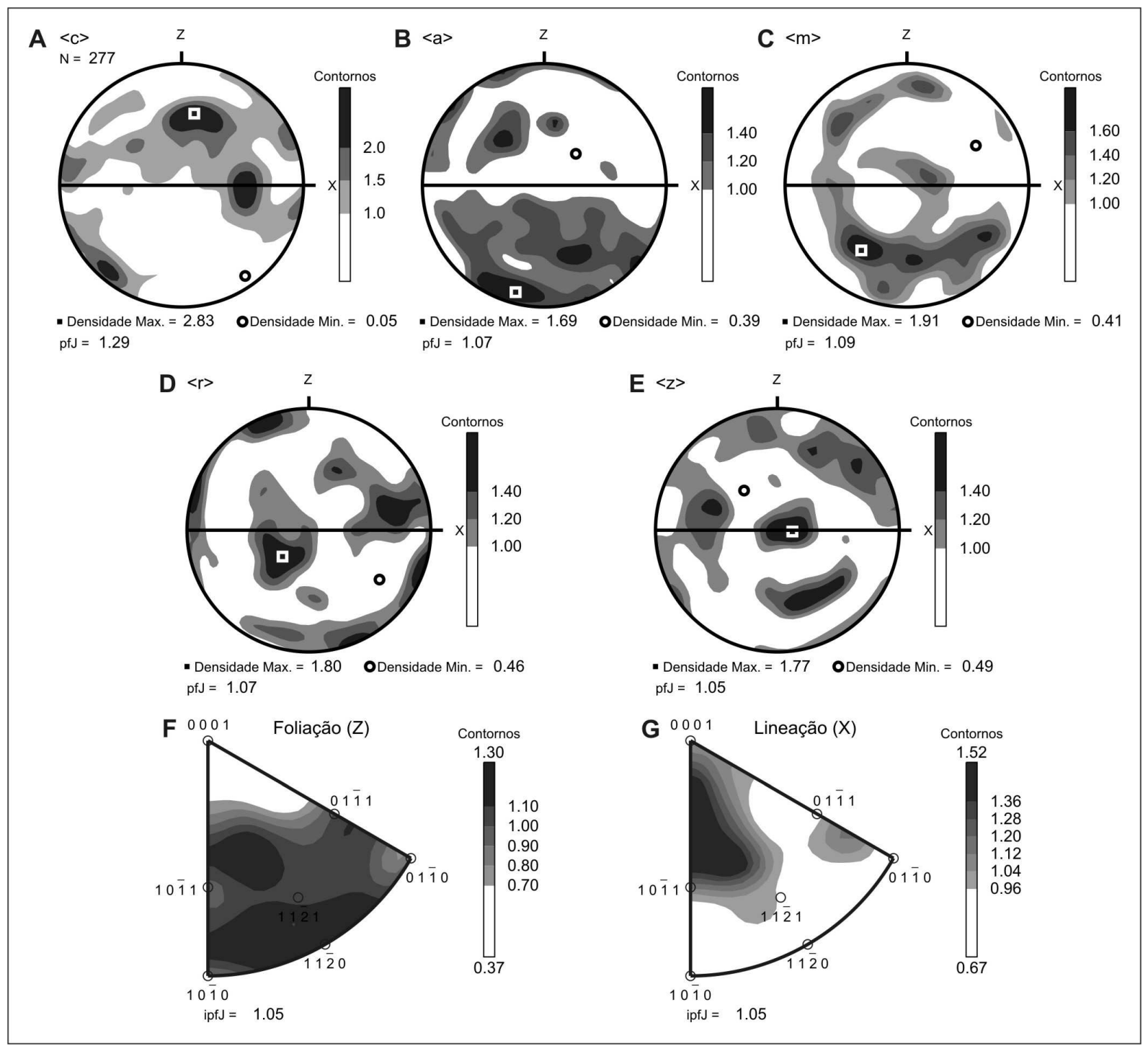

Figura 5.13 - OPR do quartzo para a amostra STX 45 apresentada em figuras de pólo diretas e inversas. As curvas de contorno estão indicadas ao lado das figuras, onde $N$ corresponde ao número de medidas. Para as figuras de pólo diretas, a foliação é vertical, E-W, e a lineação é horizontal, E-W.

Semelhante à amostra STX 285, não há um padrão definido para os eixos <c> medidos nessa seção. Nota-se, no entanto, uma maior concentração ao longo do plano $\mathrm{YZ}$, formando um ângulo de $40^{\circ}$ com o eixo $Z$, enquanto os eixos $<a>$ e $<m>$, apesar de apresentarem-se dispersos no diagrama, mostram maior concentração no quadrante SE (figura 5.13). Os eixos $<r>$ e $<z>$ estão dispostos em setores isolados do estereograma, com concentrações máximas ao redor do eixo Y. A figura de pólo inversa para a lineação mostra um máximo intermediário em $<\mathrm{c}>\mathrm{e}$, outro, em $<\mathrm{r}>$. 


\subsection{Discussão}

O padrão de OPR relativo à amostra STX 09 apresenta uma distribuição de eixos $<$ C> intermediária a guirlanda simples perpendicular ao plano de foliação e concentração máxima ao redor do eixo $\mathrm{Y}$, bem como concentração máxima de eixos <a> próxima à lineação. Essa fábrica foi produzida por deslizamento combinado dominante nos planos tromboédricos na direção <a> dominante e prismático <a> subordinado, resultante de deformação por cisalhamento simples, que tende a alinhar os eixos <a> com a direção de cisalhamento e paralelizar o plano de deslizamento ativo com o plano de cisalhamento (Schmid \& Casey 1986). Essa suposição é uma justificativa para a distribuição dos planos romboédricos, observada na figura 5.5D, que estão preferencialmente dispostos paralelos ao plano da foliação.

Existe uma transição entre um máximo simples de eixos $<\mathrm{c}>$ na periferia do diagrama, onde o deslizamento basal <a> é predominante, e um máximo simples paralelo ao eixo $\mathrm{Y}$, onde deslizamento prismático <a> é favorecido, podendo formar guirlandas simples, e, máximos intermediários, a $Y Z$, típicos de deslizamento romboédrico. Essa mudança progressiva nos padrões de OPR está relacionada com o aumento da deformação cisalhante e do grau de recristalização (ver Heilbronner \& Tullis, 2006).

Green et al. (1970) observaram ainda que eixos <c> perpendiculares a $Z$ devem ser gerados no campo de estabilidade do quartzo- $\beta$, enquanto os eixos $<c>$ na periferia do diagrama devem resultar de deformação no campo do quartzo- $\alpha$. Assim, esse padrão transicional pode estar relacionado à mudança entre os campos de estabilidade do quartzo $\alpha$ e do quartzo $\beta$ durante a deformação ou durante o "annealing".

Esse padrão de eixos $<\mathrm{c}>$ foi encontrado por vários autores ao longo da Zona de Cisalhamento do Rio Paraíba do Sul (Hippert et al. 2001, Egydio Silva et al. 2002, Bascou 2002). Hippert et al. (2001) observaram esse padrão associado à presença de domínios com fusão parcial, evidenciada pela abundância de veios quartzo-feldspáticos, enquanto as regiões sem evidência de fusão parcial apresentam fábricas de eixos <c> próximas ao eixo Z.

A distribuição dos planos romboédricos positivos preferencialmente paralelos ao plano da foliação, já mencionada anteriormente, pode estar relacionada ao efeito da recristalização estática após a deformação. Kruhl \& Peternell (2002) observaram que, em temperaturas mais altas, o deslizamento de limites de grãos se dá principalmente nos planos romboédricos. Nas rochas onde existe uma estrutura sintectônica bem desenvolvida, 
a migração de limites de grãos é limitada por esta estrutura, uma vez que os cristais com os planos romboédricos em orientações favoráveis devem ter se desenvolvido em detrimento de outros.

Outra justificativa para a disposição dos planos romboédricos pode estar relacionada à ativação das geminações de Dauphiné durante a deformação ou durante a mudança de fase de quartzo- $\beta$ para quartzo- $\alpha$. Tullis et al. (1973) mostram que a ativação das geminações de Dauphiné resulta em uma concentração dos pólos dos planos $\{r\}$ paralela ao eixo de compressão e uma diminuição das orientações preferenciais dos pólos dos planos romboédricos negativos. A diferença entre as figuras para os planos $\{r\}$ e $\{z\}$, assim como a assimetria na figura de pólo inversa para a foliação ao longo do plano a - c, poderia ser um argumento para correlacionar a orientação preferencial dos eixos < $r$ perto do pólo da foliação com a formação das geminações de Dauphiné (Tullis \& Tullis, 1972).

A distribuição de eixos $<\mathrm{C}>$ da amostra STX 23 pode ser comparada ao modelo do quartzito C de Lister \& Hobbs (1980), que sugerem que essa fábrica pode ser produzida pela ativação simultânea dos sistemas basal $<\mathrm{a}>$ e prismático $\langle\mathrm{c}\rangle$, com deslizamento prismático <a> subordinado, responsável pelas concentrações próximas ao eixo $\mathrm{Y}$, ou, ainda, pela ativação de planos muito inclinados em relação ao eixo $<\mathrm{c}>$, na direção $<\mathrm{C}+\mathrm{a}>$. Entretanto, não é clara a influência desse sistema em rochas naturalmente deformadas. Deslizamento romboédrico <a> deve também ocorrer.

No modelo citado, as concentrações de eixos $<\mathrm{c}>$ próximas a $\mathrm{X}$ se mostram em posições não estáveis, as quais devem migrar rapidamente para as posições de deslizamentos mais estáveis na direção <a>. Contudo, deve-se lembrar que esta amostra está inserida em um domínio estrutural caracterizado por forte dobramento e migmatização. A evidência de fusão parcial local nessa rocha está diretamente associada à presença de água, o que, em alta temperatura, funciona como catalisador para o deslizamento prismático na direção <c> (Mainprice et al. 1986, Kruhl 1996 e 1998).

Lister \& Dornsiepen (1982) sugerem que os agrupamentos com ângulo de $45^{\circ}$ entre os eixos X e Z (posição III) resultam da combinação entre os sistemas basal <a> e prismático $<a>$. Starkey (1979) sugere que isto é resultado do deslizamento romboédrico positivo e/ou negativo e basal subordinado.

A fraca assimetria dos eixos <a>, em relação aos eixos de referência, reflete a atuação de um componente de cisalhamento simples durante a deformação. Entretanto, esta relação 
de assimetria não pode ser extrapolada para indicar o sentido de cisalhamento, já que os agrupamentos máximos não são bem definidos.

A figura gerada pelos pólos dos planos $\{r\}$ deve estar relacionada ao deslizamento dominante ao longo desses planos (Pehl \& Wenk 2005). A existência de deslizamento conjugado durante deformação por encurtamento resulta na disposição de dois planos simétricos em relação à normal da foliação (Schmdt \& Casey 1986).

$\mathrm{Na}$ amostra STX 45, a transição entre guirlanda em pequeno círculo e guirlanda cruzada tipo I reflete um componente de cisalhamento puro no campo do achatamento durante deformação (Schmidt \& Casey 1986). Entretanto, a distribuição de eixos <a>, preferencialmente na periferia do diagrama, não está de acordo com deformação sob regime puramente coaxial.

Tal distribuição pode ser devido ao deslizamento dominante em planos romboédricos positivos e/ou negativos. De um modo geral, os sistemas de deslizamentos são semelhantes ao da amostra STX 23, exceto pela ausência de máximos de eixos <c> paralelos à lineação, o que exclui uma atuação importante da ativação do sistema prismático $<\mathrm{c}>$. Além disso, 0 deslizamento prismático<a> mostra também menor importância.

A distribuição observada para os eixos $<\mathrm{r}>$ mostra-se semelhante à observada para 0 espécime STX 09 e pode também estar relacionada à presença da geminação de Dauphiné, ou, ainda, à recristalização estática, como discutido acima. Vale observar que esta amostra é composta por grandes ribbons, em geral sem traços de deformação plástica e tampouco evidências de recristalização dinâmica após o "annealing" (Masuda et al. 1997).

O espécime STX 245 apresenta uma distribuição de eixos <c> paralelos à lineação, descritos como resultantes de deslizamento prismático na direção <c> (ver Mainprice et al. 1986). Segundo os autores, esse deslizamento é favorecido em detrimento da direção <a>, quando a deformação ocorre em altas temperaturas (700 a $\left.800^{\circ} \mathrm{C}\right)$, correspondente ao campo de estabilidade do quartzo- $\beta$, e sob condições hidratadas. Entretanto, tais condições não são comuns em ambiente de crosta inferior.

Kruhl (1996) salienta que ainda existem controvérsias na literatura entre a deformação experimental (a mesma temperatura e em condições hidratadas) do quartzo natural e do quartzo sintético, com relação aos planos de deslizamento produzidos, porém o deslizamento na direção [c] deve ocorrer no campo de estabilidade do quartzo- $\beta$. Kruhl (1998) sugere, com base em estudos experimentais, que a transição entre deslizamento 
basal <a> e prismático [c] deve diminuir de $700^{\circ} \mathrm{C}$, em condições anidras, para $600^{\circ} \mathrm{C}$ em condições hidratadas. Além disso, mesmo em rochas anidras em ambiente de crosta inferior, pequenas quantidades de água devem estar presentes, o que seria suficiente para causar enfraquecimento da estrutura do quartzo.

A assimetria dos máximos de eixos $<c>$, em relação à lineação, mostra um sentido de cisalhamento inverso àquele observado em indicadores cinemáticos mesoscópicos. Isso reforça o que tem sido discutido por alguns autores (por exemplo, Lister \& Williams 1979, Schmidt et al. 1981) quanto às restrições do uso da assimetria de fábricas de eixos $<\mathrm{C}>$ como indicadores de sentido de cisalhamento.

As amostras STX 285 e STX 287 não apresentam distribuição de eixos <c> que tenham sido descritas como resultantes de deslizamento em planos e direções específicos, não tendo, assim, significado geológico aparente. Ambas as amostras apresentam ribbons de quartzo com limites de subgrãos na forma de tabuleiro de xadrez. Kruhl (1996) sugere que este tipo de subestrutura deve ocorrer no campo de estabilidade do quartzo- $\alpha$, apesar dos diagramas da OPR das referidas espécimes não fornecerem informações adicionais. 


\section{DISCUSSÃO}

As seções geológicas analisadas neste trabalho situam-se no lado noroeste da Zona de Cisalhamento do Rio Paraíba do Sul, onde, devido ao padrão divergente característico regional, o arcabouço estrutural apresenta uma disposição geral na direção NE-SW, com mergulhos preferencialmente para sudeste. Na seção Três Rios - Matias Barbosa, este padrão divergente é bem pronunciado pela presença de estruturas de mais baixo ângulo à medida que se afasta da zona de cisalhamento principal, onde o mergulho da foliação é essencialmente vertical. Nesta seção foram reconhecidos três domínios estruturais geometricamente distintos, definidos pela predominância de elementos estruturais, que serão sintetizados abaixo, a partir da zona de cisalhamento:

- domínio estrutural I, caracterizado por estruturas de alto ângulo, fortemente milonitizadas, com lineação direcional;

- domínio estrutural II, marcado por uma trama planar de mais baixo ângulo de mergulho, fortemente dobrado e migmatizado, e lineação também de baixo ângulo;

- domínio estrutural III, onde o mergulho das estruturas planares varia de moderado a alto, com a lineação variando de oblíqua a direcional.

Entretanto, apesar do arcabouço geral aqui descrito, esses domínios não são inteiramente homogêneos, em função da presença da intercalação de diferentes estruturas dentro de cada domínio. No domínio I, as estruturas típicas dos centros das zonas de cisalhamento são intercaladas com pequenas regiões onde ocorrem estruturas de geometria semelhante às encontradas no domínio II, com dobras com superfícies axiais subparalelas às paredes das zonas de cisalhamento com eixos de caimento baixo para NE. Essas dobras apresentam uma amplificação cinemática vertical assinalada pela diminuição progressiva do seu ângulo interflancos com as proximidades das zonas de cisalhamento, sugerindo encurtamento horizontal ortogonal ao plano de cisalhamento e estiramento vertical, subordinado. Além disso, há locais onde são observados boudins máficos estirados na direção vertical, e onde a trama planar predomina em relação à trama linear (tectonitos-S).

Da mesma maneira, ocorrem no domínio II zonas de cisalhamento menores, com geometria semelhante ao do domínio I, onde também se observa uma verticalização das superfícies axiais das dobras nas proximidades das referidas zonas. Apesar do maior componente de achatamento nesse domínio, verifica-se a existência de corpos graníticos e enclaves máficos estirados segundo a lineação e, localmente, tectonitos-L, com formação de mullions paralelos à lineação de estiramento mineral. 
A geometria de ambos os padrões de dobras (superfícies axiais de alto e baixo ângulo) são compatíveis com dobras formadas por movimentos transcorrentes, em que houve a participação de um importante componente ortogonal de encurtamento. Esta relação sugere que a nucleação das estruturas se deu antes do desenvolvimento das zonas de cisalhamento, porém o seu desenvolvimento foi concomitante, pelo menos em parte, à etapa principal de deformação. Nas regiões mais afastadas das zonas de cisalhamento, as dobras apresentam superfícies axiais mais oblíquas do que nas proximidades destas zonas. Essa geometria está relacionada com a nucleação contínua de dobras nos incrementos da deformação durante o desenvolvimento dessas zonas (Sanderson \& Marchini 1984, Fossen et al. 1994), onde as dobras mais antigas se apresentam mais oblíquas, enquanto as mais novas se tornam gradativamente mais paralelas à deformação.

O domínio III corresponde à região mais heterogênea em termos de partição da deformação, mostrando maior concentração de zonas de cisalhamento locais que no domínio II. Algumas dessas estruturas apresentam uma trama planar bem desenvolvida, porém não se observa uma lineação mineral ou de estiramento marcante (tectonitos-S), sugerindo nestes casos a importância do cisalhamento puro na deformação Nas regiões mais afastadas da zona de cisalhamento, a estrutura é caracterizada por uma foliação de mergulho moderado para SE, lineação de caimento moderado para NE, e dobras com superfícies axiais de alto ângulo de mergulho. A existência de estruturas em leque em escala de afloramento, dada pela variação na foliação, sugere que estas estruturas foram formadas em regime transpressivo.

Os indicadores cinemáticos são compatíveis nos três domínios, apontando para movimento destral, quando analisados segundo plano horizontal, e, em regiões, com a foliação de ângulo baixo a moderado, mostram movimento de topo para SW. A geometria das dobras, na seção em geral, pode também ser considerada cinematicamente compatível, como já foi discutido acima para as dobras do domínio II, onde elas são mais freqüentes.

Dessa forma, a variação geométrica dos elementos estruturais descritos neste trabalho aponta para uma mudança na relação entre cisalhamento puro e cisalhamento simples ao longo do perfil, onde o componente de cisalhamento simples é acomodado principalmente nas zonas de cisalhamento transcorrentes, e o componente de cisalhamento puro é acomodado de forma mais difusa nas porções intermediárias a essas zonas (Teyssier et al. 1995). Essas regiões são mais bem entendidas, em termos de mecanismos de deformação e de formação das estruturas, quando consideradas no campo de deformação em regime transpressivo dominado por cisalhamento simples, segundo a classificação de Fossen et al. (1994), enquanto as zonas de cisalhamento estão próximas 
ao campo de deformação com $W_{k}=1$ (cisalhamento simples). Se for considerado o modelo de deformação transpressivo não-confinado de Jones et al (1997), o domínio estrutural II pode ainda ser comparado ao regime de deformação com extrusão lateral não-coaxial.

As três amostras descritas para o perfil de Três Rios - Matias Barbosa exibem diferentes padrões de OPR, cujas localizações estão indicadas na figura 5.3. Observa-se, claramente, a maior contribuição de deformação não-coaxial nos estudos da OPR da amostra localizada no centro da zona de cisalhamento, conforme já discutido anteriormente. A contribuição de um componente de cisalhamento puro aumenta à medida que se afasta da zona de cisalhamento. Entretanto, esta variação na relação cisalhamento puro versus cisalhamento simples não pode ser considerada de uma forma linear, pois são mecanismos de deformação que podem coexistir no espaço orogênico ou alternar-se no tempo e estão estreitamente vinculados com a partição da deformação durante a evolução do orógeno. Embora tenha sido analisada apenas uma amostra relativa a cada domínio estrutural, já foi possível observar que os domínios estruturais acham-se separados pela predominância das estruturas, uma vez que são observadas em escala de afloramento intercalações de pequenas zonas de cisalhamento, onde o mecanismo de deformação predominante, pelo menos durante certo período da deformação, foi o de cisalhamento simples.

As investigações de OPR dos cristais de quartzo para os domínios estruturais I e III (amostras STX 09 e STX 45, respectivamente) apresentam, principalmente, deslizamento segundo os planos romboédricos, condição que é compatível com deformação de mais baixa temperatura do que as obtidas para as rochas da região por dados geotermobarométricos, cujos valores situam-se entre 750 e 850ㄷ (Porcher et al. 1995 e 2000), temperaturas nas quais devem predominar deslizamentos prismáticos nas direções $<\mathrm{a}>\mathrm{e}<\mathrm{c}>$.

As microestruturas descritas nessas rochas evidenciam uma extrema mobilidade dos limites dos grãos de quartzo. O crescimento exagerado dos ribbons e a ausência de subestruturas significativas afetando os cristais sugerem que estas rochas foram sujeitas a um importante processo de recristalização estática após a deformação.

Já os estudos de OPR da amostra STX 23 (domínio estrutural II) apontam para uma importante contribuição de deslizamento prismático $<\mathrm{c}>$, de acordo com as temperaturas estimadas e a grande presença de fluidos que favoreceu a intensa migmatização nessas rochas. Nas microestruturas observadas é marcante a evidência de migração de borda de grãos durante a recristalização dinâmica (por exemplo, contatos fortemente interlobados entre os grãos e desenvolvimento de estruturas tipo "pinning"), e não foram registradas 
evidências texturais de que o processo de "annealing" tenha tido uma grande influência após a deformação principal que afetou essa rocha.

Kruhl (1996) mostra, num gráfico PxT, que a linha que separa os campos onde ocorre o deslizamento na direção $<\mathrm{c}>$ (podendo ser combinado com $<\mathrm{a}>$ ) daquele onde ocorre somente deslizamento na direção <a> é coincidente com a linha que divide os campos de estabilidade do quartzo- $\alpha$ e quartzo- $\beta$.

Assim, a variação entre as OPR dos espécimes STX 09, STX 23 e STX 45 pode estar associada a uma mudança do gradiente termal ao longo da seção, sendo que a amostra STX 23 sofreu metamorfismo em condições de pressão e temperatura compatível com a do campo do quartzo- $\beta$, ou a contribuição do deslizamento na direção <c> nesta amostra está associada à presença de grande quantidade de fluidos, condição que facilita o deslizamento nesta direção em temperaturas mais baixas. Ou ainda as OPR relativas aos domínios I e III estão provavelmente associadas com um importante processo de difusão pós-tectônica, não podendo, portanto, ser interpretadas simplesmente em termos de cinemática e sistemas de deslizamentos ativos, enquanto a amostra relativa ao domínio II pode corresponder a uma fábrica não modificada pela recristalização estática posterior à deformação.

O arcabouço estrutural da seção Barra do Piraí - Conservatória foi dividida em domínios estruturais de menor extensão, descritos a seguir:

- domínio estrutural I, caracterizado por estruturas de alto ângulo e lineação direcional;

- domínio estrutural II, marcado por uma trama planar de ângulo de mergulho baixo a moderado para NW;

- domínio estrutural III, que corresponde a uma zona de cisalhamento relativamente espessa, com estruturação geral semelhante ao do domínio I;

- domínio estrutural IV, marcado por uma foliação de baixo ângulo de mergulho para SE;

- domínio estrutural V, caracterizado por uma foliação subvertical, localmente dobrada, e lineação direcional.

Assim como na seção Três Rios - Matias Barbosa, os domínios aqui definidos também não são homogêneos. O domínio estrutural I mostra uma intercalação de zonas de cisalhamento locais com setores que apresentam foliação levemente rotacionada para NNW, bem como setores com foliação de mais baixo ângulo, desprovidos de lineação mineral e de estiramento, onde o mecanismo de cisalhamento puro deve ter sido mais importante. 
Nos domínios III e V ocorre também a intercalação de setores que apresentam foliação na direção NNW, porém no domínio III a foliação de mais ângulo ocorre apenas como sobreposição à trama de alto ângulo. Já no domínio $\mathrm{V}$, a foliação de alto ângulo se sobrepõe à foliação de mais baixo ângulo, e, semelhante à seção Três Rios - Matias Barbosa, ocorre uma verticalização das dobras com as proximidade das zonas de cisalhamento. A partir dessa inversão de nucleação das estruturas e da maior freqüência de dobras no domínio $\mathrm{V}$, considera-se que esse domínio sofreu uma maior contribuição de achatamento durante a deformação do que o domínio III (Tikoff \& Teyssier 1994).

A disposição das estruturas relativas aos domínios II, III e IV é interpretada como resultante de uma extrusão local vinculada a uma zona de cisalhamento central. Apesar da ausência de indicadores cinemáticos nos domínios II e IV, a presença de indicadores de movimento na porção mais a noroeste do domínio III fora do plano XZ de deformação, indica ascensão do bloco sudeste, quadro este que está de acordo com suposição acima. A deformação nessa região se deu provavelmente em regime transpressivo não confinado, dominada por cisalhamento puro triaxial (Jones et al. 1997), onde a zona de cisalhamento central foi gerada após a exumação, resultante do componente de cisalhamento simples subordinado.

A OPR dessa zona de cisalhamento no centro da zona de extrusão, representada pelo espécime STX 245, que apresenta predominância de deslizamento prismático $<\mathrm{c}>$, é compatível com deformação dominada por cisalhamento simples em temperatura superior a $800^{\circ}$ C. Esta OPR está de acordo com o grau de metamorfismo estimado para a deformação na região (zona do ortopiroxênio, segundo Heilbron 1993). Dessa forma, essa rocha não sofreu uma recristalização pós-cinemática significativa ou esse processo não modificou a OPR existente (Heilbronner \& Tullis 2002). As amostras dos domínios IV e V apresentam subestruturas compatíveis com temperaturas de deformação no campo de estabilidade do quartzo- $\beta$ (Kruhl 1996), onde os limites de subgrãos com padrão em forma de tabuleiro de xadrez devem ser resultantes da contribuição similar de deslizamento de discordâncias nas direções $<\mathrm{a}>\mathrm{e}<\mathrm{c}>$. Entretanto, as OPR desses espécimes não apresentaram resultados com significado geológico evidente para uma discussão sobre os mecanismos de deformação, condições de temperatura e presença de fluidos da região estudada.

Com base nos dados apresentados relativos às duas seções, nota-se que não há uma correlação lateral direta entre as mesmas, a não ser pelas regiões adjacentes à zona de cisalhamento principal. Os domínios mais afastados da mesma não se estendem lateralmente de maneira homogênea. Essa heterogeneidade é marcada principalmente pelas regiões de extrusão, que estão associadas com diferentes estruturas. A região 
interpretada como resultante de extrusão lateral na seção Três Rios - Matias Barbosa está diretamente relacionada ao desenvolvimento da Zona de Cisalhamento Paraíba do Sul (ver também Dehler 2002 e Dehler \& Machado 2002), enquanto na seção Barra do Piraí Conservatória, é vinculada a uma zona de cisalhamento menos expressiva, aparentemente sem relação direta com a estrutura regional.

Essas estruturas, apesar de aparentemente independentes, são cinemática e mecanicamente compatíveis, onde o desenvolvimento da zona de cisalhamento menor está associado à mesma deformação que gerou a zona principal. Esse comportamento reflete, aparentemente, uma menor influência da Zona de Cisalhamento do Rio Paraíba do Sul nos setores adjacentes mais a sul do Estado do Rio de Janeiro do que na região mais a norte. Observação semelhante se dá pelo padrão divergente menos pronunciado na região sul. 


\section{CONCLUSÕES}

Os dados aqui apresentados revelam uma variação das estruturas ao longo das seções geológicas levantadas na aba norte da estrutura divergente do Rio Paraíba do Sul. A mudança na geometria das estruturas pode ser caracterizada em termos da razão entre os componentes de cisalhamento simples e cisalhamento puro, sendo esta maior para as regiões marcadas pelo desenvolvimento de zonas de cisalhamento destrais de alto ângulo, e menor para as regiões onde predominam estruturas típicas de achatamento (grande quantidade de dobras, boudins estirados na direção vertical, tectonitos-S e zonas de extrusão). Esta diferença do componente rotacional entre os domínios é interpretada como uma partição do componente rotacional da deformação na região como um todo. Dessa forma, as zonas de cisalhamento são responsáveis pela acomodação da maior parte do cisalhamento simples, enquanto o componente de cisalhamento puro aparece de forma mais difusa ao longo das seções.

Ambas as seções sugerem a existência de regiões resultantes da extrusão tectônica em regime transpressivo. Na seção Três Rios - Matias Barbosa, a extrusão está vinculada à Zona de Cisalhamento do Rio Paraíba do Sul, com movimentos paralelos e oblíquos à estruturação regional, acompanhados pela geração de uma forte migmatização e desenvolvimento importante de dobras. Já na seção Barra do Piraí - Conservatória, a extrusão tectônica está aparentemente associada com uma zona de cisalhamento secundária, resultante de movimentos ascendentes e direcionais, responsáveis pela exumação de rochas granulíticas.

Além da variação lateral comentada acima, observa-se na área estudada relações de sobreposição entre as estruturas. A verticalização e rotação das dobras com as proximidades das zonas de cisalhamento sugerem que estas estruturas tenham se desenvolvido em momentos tardios ao de nucleação das dobras. Da mesma maneira, as zonas de cisalhamento vinculadas aos domínios de extrusão devem ter-se desenvolvido em um momento tardio ao de geração dessas rochas.

As relações de sobreposição de estruturas observadas na seção Barra do Piraí Conservatória, assim como a presença de indicadores cinemáticos fora do plano $X Z$ de deformação na zona de cisalhamento no centro do domínio de extrusão, sugerem que o desenvolvimento dessas estruturas coexistiu, pelo menos em parte do tempo, durante a evolução tectônica do segmento considerado. 
Além disso, com base nas modelagens teóricas disponíveis, estas estruturas podem ser consideradas cinematicamente compatíveis em termos de um modelo de evolução tridimensional. Sendo assim, a nucleação das estruturas, onde é clara a predominância do componente de achatamento, deve ter sido, em geral, anterior à nucleação das estruturas tipicamente não-coaxiais, mas o desenvolvimento destas não impediu o desenvolvimento das estruturas coaxiais. Em outras palavras, a mudança lateral e a relação de sobreposição das estruturas são interpretadas como resultantes da partição espacial e temporal da deformação em regime de deformação transpressivo não-confinado, segundo uma evolução tectônica simples.

Os diferentes domínios nas duas seções dificilmente podem ser diretamente correlacionados lateralmente, assim como as características das extrusões tectônicas, o padrão divergente nas regiões mais a norte do Estado do Rio de Janeiro e a maior independência das estruturas nas regiões mais a sul. Um mapeamento estrutural mais detalhado é necessário para determinar o comportamento das estruturas nas regiões intermediárias.

As diferentes OPR analisadas refletem diretamente a variação nos componentes de cisalhamento simples e cisalhamento puro discutida acima. A predominância da atuação de diferentes deslizamentos de discordâncias pode ainda estar associada a um gradiente termal ao longo das seções, à diferença na influência de fluidos durante a deformação ou ainda ao efeito da difusão pós-cinemática. Apesar de terem sido encontradas microestruturas típicas do efeito de "annealing" após a deformação nos espécimes com OPR de mais baixa temperatura, um estudo de OPR mais detalhado, associado com dados geotermobarométricos, é necessário para esclarecer essa questão. 


\section{REFERÊNCIAS BIBLIOGRÁFICAS}

Almeida F.F.M., Amaral G., Cordani U.G., Kawashita K. 1973. The precambrian evolution of the South American cratonic margin south of Amazon river. In: E.M. Nairn \& F.G. Stehli (eds.) The Ocean Basins and Margins. Plenun, New York, pp.: 411-446.

Almeida F.F.M., Brito-Neves B.B., Carneiro C.D.R. 2000. The origin and evolution of the South American Platform. Earth-Science Reviews, 50:77-111.

Almeida F.F.M. \& Hasui Y. (Eds.) 1984. O Pré-Cambriano do Brasil. Edgard Blucher, São Paulo, 378 pp.

Almeida F.F.M., Hasui Y., Brito-Neves B.B., Fuck R.A. 1977. Províncias Estruturais Brasileiras. In: SBG, Simpósio de Geologia do Nordeste, 8, Campina Grande,Atas: 363-391.

Almeida F.F.M., Hasui Y., Carneiro C.D.R. 1975. O Lineamento de Além Paraíba. Anais da Academia Brasileira de Ciências, 48(suplemento):575.

Almeida J.C.H. 2000. Zonas de cisalhamento dúctil de alto grau do Médio Vale do Rio Paraíba do Sul. Tese de Doutoramento, Instituto de Geociências e Ciências Exatas, Universidade Estadual Paulista, 190 pp.

Bascou J. 2002. Relações entre microestruturas, mecanismos de deformação e propriedades físicas anisotrópicas em rochas de alto grau de metamorfismo: estudo de alguns eclogitos e granulitos. Tese de Doutoramento, Instituto de Geociências, Universidade de São Paulo, 132 pp.

Campanha G.A.C. 1980. O Lineamento de Além Paraíba na área de Três Rios (RJ). Dissertação de Mestrado, Instituto de Geociências, Universidade de São Paulo, 99 pp.

Campanha G.A.C. 1981. O Lineamento de Além Paraíba na área de Três Rios - RJ. Revista Brasileira de Geociências, 11:159-171.

Correa Neto A.V., Dayan H., Valença J.G., Cabral A.R. 1993. Geologia e estrutura da zona de cisalhamento do Rio Paraíba do Sul entre Três Rios - RJ e Sapucaia - RJ. In: SBG, Simpósio de Geologia do Sudeste, 3, Rio de Janeiro,Atas: 194-200. 
Dayan H. \& Keller J.V.A. 1990. A Zona de Cisalhamento do Rio Paraíba do Sul nas vizinhanças de Três Rios (RJ): uma análise da deformação dada por algumas feições estruturais. Revista Brasileira de Geociências, 19(4):494-506.

Dehler N.M. 2002. Extrusão tectônica oblíqua em regime transpressivo no Cinturão Paraibides, RJ. Tese de Doutoramento, Instituto de Geociências, Universidade de São Paulo, $161 \mathrm{pp}$.

Dehler N.M. \& Machado R. 2002. Geometria e cinemática da aba sul da estrutura divergente do Rio Paraíba do Sul ao longo da seção Areal - Três Rios, Rio de Janeiro. Revista Brasileira de Geociências, 32(4):481-490.

Dutton B.J. 1997. Finite strains in transpression zones with no boundary slip. Journal of Structural Geology, 19(9):1189-1200.

Ebert H. 1968. Ocorrências de fácies granulíticas no sul de Minas Gerais e em áreas adjacentes em dependência da estrutura orogênica: hipóteses sobre sua origem. Anais da Academia Brasileira de Ciências, 40(suplemento):215-229.

Ebert H.D. 2005. Estruturação tectônica e arcabouço crustal da região de interseção entre os cinturões Ribeira e Brasília: integração de dados geológicos, estruturais, geofísicos, geocronológicos e fisiográficos através de geoprocessamento e modelagem tridimensional. Tese de Livre-Docência, Instituto de Geociências e Ciências Exatas, Universidade Estadual Paulista, 236 pp.

Ebert H.D. \& Hasui Y. 1998. Transpressional tectonics and strain partitioning during oblique colision between three plates in the Precambrian of southeast Brazil. In: R.E. Holdsworth, R.A. Strachan, J.F. Dewey (eds.) Continental transpressional and transtensional tectonics. Geological Society, Special Publication, 135, London, pp.: 231-252.

Ebert H.D., Hasui Y., Costa J.B.S. 1991. O caráter transpressivo do Cinturão Transcorrente do Rio Paraíba do Sul. In: Simpósio Nacional de Estudos Tectônicos, 3, Rio Claro, SP,Boletim: 139-141.

Ebert H.D., Hasui Y., Sartorato G., Almeida S.H., Costa J.B.S. 1993. Arcabouço estrutural e tectônica transpressiva das faixas móveis da borda sul e sudeste do Cráton do São Francisco e da Sintaxe de Guaxupé. In: SBG Núcleo MG, Simpósio Nacional de Estudos Tectônicos, 4,Anais: 166-171. 
Ebert H.D., Neves M.A., Hasui Y., Lopes J.A., Guerra M. 1995. Compartimentação crustal e evolução cinemática da Província Mantiqueira através da modelagem física. In: SBG, Simpósio Nacional de Estudos Tectônicos, 5, Gramado,Boletim de Resumos Expandidos: 26-28.

Ebert H.D., Neves M.A., Hasui Y., Szatmari P., Aires J.R. 1993. Evolução dos cinturões de cisalhamento entre os blocos São Paulo, Vitória e Brasília através da tectônica colisional oblíqua - uma modelagem física. In: SBG, Simpósio Nacional de Estudos Tectônicos, 4, Belo Horizonte, Anais: 254-258.

Egydio-Silva M. 1996. Zona de cisalhamento de alta temperatura - O Lineamento de Além Paraíba (RJ). Tese de Livre-Docência, Instituto de Geociências, Universidade de São Paulo, 226 pp.

Egydio-Silva M., Vauchez A., Bascou J., Hippertt J. 2002. High-temperature deformation in the Neoproterozoic transpressional Ribeira belt, southeast Brazil. Tectonophysics, 352:203-224.

Egydio-Silva M., Vauchez A., Raposo M.I.B., Bascou J., Uhlein A. 2005. Deformation regime variations in an arcuate transpressional orogen (Ribeira belt, SE Brazil) imaged by anisotropy of magnetic susceptibility in granulites. Journal of Structural Geology, 27:1750-1764.

Fossen H. \& Tikoff B. 1993. The deformation matrix for simultaneous simple shearing, pure shearing and volume change, and its application to transpression-transtension tectonics. Journal of Structural Geology, 15:413-422.

Fossen H., Tikoff B., Teyssier C. 1994. Strain modeling of transpressional and transtensional deformation. Norsk Geologisk Tidsskrift, 74:134-145.

Green H.W. 1967. Quartz: extreme preferred orientation produced by annealing. Science, 157:1444 - 1447.

Green H.W., Griggs D.T., Christie J.M. 1970. Syntectonic and annealing recrystallization of fine-grained aggregates. In: P. Paulitsch (eds.) Experimental and Natural Rock Deformation. Springer-Verlag, Berlin, pp.: 272- 335.

Harland W.B. 1971. Tectonic transpression in Caledonian Spitsbergen. Geological Magazine, 108:27-42. 
Heilbron M. 1993. Evolução tectono-metamórfica da seção Bom Jardim de Minas (MG) Barra do Piraí (RJ). Setor central da Faixa Ribeira. Tese de Doutoramento, Instituto de Geociências, Universidade de São Paulo, 261 pp.

Heilbron M., Pedrosa-Soares A.C., Campos-Neto M.C., Silva L.C., Trouw R., Janasi V. 2004. A Província Mantiqueira. In: V. Mantesso, A. Bartorelli, C.D.R. Carneiro, B.B. BritoNeves (eds.) Geologia do Continente Sul-Americano: evolução da obra de Fernando Flávio Marques de Almeida. Beca Produções Culturais Ltda, São Paulo, pp.: 203-235.

Heilbron M., Tupinambá M., Almeida J.C.H., Valeriano C.M., Valladares C.S., Duarte B.P. 1998. New constraints on the tectonic organization and structural styles related to the Brasiliano Collage of the central segment of Ribeira Belt, SE Brazil. In: International Conference on Basement Tectonics, 14, Ouro Preto, MG: 15-17.

Heilbron M., Valeriano C.M., Almeida J.C.H., Tupinambá M. 1991. A Megassinformal do Paraíba do Sul e sua implicação na compartimentação tectônica do setor central da Faixa Ribeira. In: SBG, Simpósio de Geologia do Sudeste, 2, São Paulo,Atas: 519527.

Heilbron M., Valeriano C.M., Valladares C.S., Machado N. 1995. A Orogênese Brasiliana no segmento central da Faixa Ribeira, Brasil. Revista Brasileira de Geociências, 25(4):249-266.

Heilbronner R. \& Tullis J. 2002. The effect of static annealing on microstructures and crystallographic preferred orientations of quartzites experimentally deformed in axial compression and shear. In: S. De Meer, R. Drury Martyn, J.H.P. De Bresser, M.P. Gill (eds.) Deformation Mechanisms, Rheology and Tectonics; Current Status and Future Perspectives. Geological Society of London, Special Publications, 200, London, pp.: 191-218.

Heilbronner R. \& Tullis J. 2006. Evolution of c axis pole figures and grain size during dynamic recrystallization: Results from experimentally sheared quartzite. Journal of Geophysical Research, 111:B10202, doi:10.1029/2005JB004194.

Hippertt J.F.M., Rocha A., Lana C., Egydio-Silva M., Takeshita T. 2001. Quartz plastic segregation and ribbon development in high-grade striped gneisses. Journal of Structural Geology, 23:67-80. 
Jiang D., Lin L., Williams P.F. 2001. Deformation path in high-strain zones, with reference to slip partitioning in transpressional plate-boundary regions. Journal of Structural Geology, 23(6-7):991-1005.

Jiang D. \& White J.C. 1995. Kinematic of rock flow and the interpretation of geological structures, with particular reference to shear zone. Journal of Structural Geology, 17:1249-1265.

Jiang D. \& Williams P.F. 1998. High strain zones: a unified model. Journal of Structural Geology, 20:1105-1120.

Jones R.R., Holdsworth R.E., Bailey W. 1997. Lateral extrusion in transpression zones: the importance of boundary conditions. Journal of Structural Geology, 19(9):1201-1217.

Jones R.R. \& Tanner P.W.G. 1995. Strain partitioning in transpression zones. Journal of Structural Geology, 17:793-802.

Karniol T.R., Machado R., Dehler N.M. 2008. Transpressive dextral shear in the Italva Itaperuna section, northern State of Rio de Janeiro, Brazil. Anais da Academia Brasileira de Ciências. (no prelo).

Klein C. \& Hurlbut C.S. (Eds.) 1999. Manual of Mineralogy. John Wiley \& Sons, New York, $596 \mathrm{pp}$.

Kruhl J.H. 1996. Prism- and basal-plane parallel subgrain boundaries in quartz: a microstrutuctural geothermobarometer. Journal of Metamorphic Geology, 14:581-589.

Kruhl J.H. 1998. Prism- and basal-plane parallel subgrain boundaries in quartz: a microstrutuctural geothermobarometer: Reply. Journal of Metamorphic Geology, 16:142-146.

Kruhl J.H. \& Peternell M. 2002. The equilibration of high-angle grain boundaries in dynamically recrystallized quartz: the effect of crystallography and temperature. Journal of Structural Geology, 24(6-7):1125-1137.

Lister G.S. \& Dornsiepen U.F. 1982. Fabric transitions in the Saxony granulite terrain. Journal of Structural Geology, 4(1):81-92. 
Lister G.S. \& Hobbs B.E. 1980. The simulation o! tabric development during plastic deformation and its application to quartzite: the influence o! detormation history. Journal of Structural Geology, 2(3):355-370.

Lister G.S. \& Williams P.F. 1979. Fabric development in shear zones: theoretical controls and observed phenomena. Journal of Structural Geology, 1(4):283-297.

Lister G.S. \& Williams P.F. 1983. The partitioning of deformation in flowing rock masses. Tectonophysics, 92:1-33.

Machado N., Valladares C., Heilbron M., Valeriano C. 1996. U-Pb geochronology of the central Ribeira Belt (Brazil) and implications for the evolution of the Brazilian Orogeny. Precambrian Research, 79:347-361.

Machado R. 1983. Considerações sobre a estruturação tectônica divergente da porção ocidental do Estado do Rio de Janeiro. In: SBG, Simpósio Regional de Geologia, 4, São Paulo,Atas: 135-146.

Machado R. 1984. Evolução geológica e análise estrutural da região de Vassouras e Paracambi, porção ocidental do Estado do Rio de Janeiro. Tese de Doutoramento, Instituto de Geociências, Universidade de São Paulo, 196 pp.

Machado R. \& Dehler N.M. 2002. Revisão e discussão do significado tectônico de granitóides do tipo-S neoproterozóicos no Estado do Rio de Janeiro. Revista Brasileira de Geociências, 32(4):471-480.

Machado R. \& Endo I. 1993. Cinturão de Cisalhamento Atlântico: um exemplo de tectônica transpressional neoproterozóica. In: SBG Núcleo MG, Simpósio Nacional de Estudos Tectônicos, 4,Anais: 189-191.

Machado R. \& Endo I. 1993. A megaestrutura em flor positiva do Vale do Rio Paraíba do Sul no Rio de Janeiro e suas implicações tectônicas regionais. In: SBG, Simpósio de Geologia do Sudeste, 3, Rio de Janeiro,Atas: 208-213.

Mainprice D. 2007. ftp://www.gm.univ-montp2.fr/mainprice//CareWare_Unicef_Programs/.

Mainprice D., Bouchez J.L., Blumenfeld P., Tubià J.M. 1986. Dominant $c$ slip in naturally deformed quartz: Implications dor dramatic plastic softening at high temperature. Geology, 14:819-822. 
Masuda T., Morikawa T., Nakayama Y., Suzuki S. 1997. Grain boundary migration of quartz during annealing experiments at high temepratures and pressures, with implications for metamorphic geology. Journal of Metamorphic Geology, 15:311-322.

Miranda E.E. \& Coutinho A.C. 2005. Brasil Visto do Espaço. Campinas, Embrapa Monitoramento por Satélite.

Morales L.F.G., Hinrichs R., Fernandes L.A.D. 2007. A técnica de difração de elétrons retroespalhados (EBSD) em microscópio eletrônico de varredura (MEV) e sua aplicação no estudo de rochas deformadas. Pesquisas em Geociências, 34(1):19-34.

Nummer A.R., Machado R., Dehler N.M. 2007. Pluton emplacement in a releasing bend in a transpressive regime: the arrozal granite in the Paraíba do Sul shear belt, Rio de Janeiro. Anais da Academia Brasileira de Ciências, 79(2):299-305.

Oldow J.S., Bally A.W., Avé-Lallement H.G. 1990. Transpression, orogenic float, and lithospheric balance. Geology, 18:991-994.

Passchier C.W. \& Trouw R.A.J. (Eds.) 2005. Microtectonics. Springer, Berlin, 366 pp.

Pehl J. \& Wenk H.R. 2005. Evidence for regional Dauphine' twinning in quartz from the Santa Rosa mylonite zone in Southern California. A neutron diffraction study. Journal of Structural Geology, 27:1741-1749.

Peternel R., Trouw R.A.J., Schmitt R.S. 2005. Interferência entre duas faixas móveis neoproterozóicas: o caso das faixas Brasília e Ribeira no sudeste do Brasil. Revista Brasileira de Geociências, 35(3):297-310.

Porcher C., Fernandes L., Droop G., Brodie K.H. 2000. Re-equilibration of granulites in a transcurrent shear zone in southeastern Brazil. In: International Geological Congress, 31, Rio de Janeiro.

Porcher C., Fernandes L., Egydio-Silva M., Vauchez A. 1995. Dados preliminares do metamorfismo M1 da Faixa Ribeira: Região de Três Rios e Santo Antônio de Pádua (RJ). In: Simpósio Nacional de Estudos Tectônicos, 5, Gramado (RS): 71-73.

Ragatky D., Tupinambá M., Duarte B.P. 2000. Sm/Nd data of metasedimentary rocks from the central segment of Ribeira Belt, southeastern Brazil. Revista Brasileira de Geociências, 30(1):165-168. 
Ragatky D., Tupinambá M., Heilbron M., Duarte B.P., Valladares C. 1999. New Sm/Nd isotopic data from pre-1.8 Ga basement rocks of Central Ribeira Belt, SE Brazil. In: South American Symposium on Isotope Geology, 2,Actas: 346-348.

Robin P.-Y.F. \& Cruden A.R. 1994. Strain and vorticity patterns in ideally ductile transpression zones. Journal of Structural Geology, 16(4):447-466.

Rosier G.F. 1957. A geologia da Serra do Mar entre os picos da Maria Comprida e do Desengano. Boletim da Divisão de Geologia e Mineralogia:166pp.

Rosier G.F. 1965. Pesquisas geológicas na parte oriental do Estado do Rio de Janeiro. Boletim da Divisão de Geologia e Mineralogia:222pp.

Sadowski G.R. 1983. Sobre a geologia estrutural de cinturões de cisalhamento continentais. Tese de Livre-Docência, Instituto de Geociências, Universidade de São Paulo, 108 pp.

Sanderson D.J. \& Marchini W.R.D. 1984. Transpression. Journal of Structural Geology, 6(5):449-458.

Schmid S.M. \& Casey M. 1986. Complete fabric analysis of some commonly observed quartz c-axis patterns. In: H.C. Heard \& B.E. Hobbs (eds.) Mineral and Rock Deformation, Laboratory Studies - The Patterson Volume. Geophysical Monograph, American Geophysical Union, 36, Washington, pp.: 263-286.

Schmid S.M., Casey M., Starkey J. 1981. An illustration of the advantages of a complete texture analysis described by the orientation distribution function (ODF) using quartz pole figure data. Tectonophysics, 78:101-117.

Schobbenhaus C., Gonçalves J.H., Santos J.O.S., Abram M.B., Leão Neto R., Matos G.M.M., Vidotti R.M., Ramos M.A.B., Jesus J.D.A. 2004. Carta geológica do Brasil ao milionésimo, sistema de informações geográficas - SIG. Folha Rio de Janeiro (SF23). Brasília, CPRM, 1:1000000.

Starkey J. 1979. Petrofabric analysis of Saxony Granulites by optical and X-ray diffraction methods. Tectonophysics, 58:201-219.

Stipp M., Stünitz H., Heilbronner R., Schmid S. 2002. The eastern Tonale fault zone: a 'natural laboratory' for crystal plastic deformation of quartz over a temperature range from 250 to $700{ }^{\circ} \mathrm{C}$. Journal of Structural Geology, 24:1861-1884. 
Teyssier C., Tikoff B., Markley M. 1995. Oblique plate motion and continental tectonics. Geology, 23:447-450.

Tikoff B. \& Teyssier C. 1994. Strain modeling of displacement-field partitioning in transpressional orogens. Journal of Structural Geology, 16(11):1575-1588.

Tullis J., Christie J.M., Griggs D.T. 1973. Microstructures and preferred orientations of experimentally deformed quartzites. Geological Society of America Bulletin 84:297-314.

Tullis J. \& Tullis T. 1972. Preferred orientation of quartz produced by mechanical Dauphiné twinning: thermodynamics and axial experiments. In: H. Heard (eds.) Flow and Fracture of Rocks, The Griggs Volume. American Geophysical Union, Geophysical Monograph, 16, Washington, pp.: 67-82.

Turner F.J. \& Weiss L.E. (Eds.) 1963. Structural analysis of metamorphic tectonites. McGraw Hill, New York, 545 pp.

Valladares C.S. 1996. Evolução geológica do Complexo Paraíba do Sul, no segmento central da Faixa Ribeira, com base em estudos de geoquímica e geocronologia U-Pb. Tese de Doutoramento, Instituto de Geociências, Universidade de São Paulo, 147 pp.

Valladares C.S., Heilbron M., Machado N., Valeriano C.M. 1997. Provenance of central Ribeira Belt metasediments using ${ }^{207} \mathrm{~Pb} /{ }^{206} \mathrm{~Pb}$ ages on zircon by laser-ablation ICPMS. In: South-American Symposium on Isotope Geology, 1, Campos do Jordão, SP, Extend Abstracts: $323-325$.

Vauchez A., Tommasi A., Egydio-Silva M. 1994. Self-indentattion of a heterogeneous continental litosphere. Geology, 22:967-970. 
ANEXO I - EXTRUSÃO TECTÔNICA E TRANSPORTE LATERAL DE MASSA NA PORÇÃO CENTRAL DO CINTURÃO PARAÍBA DO SUL, SEÇÃO TRÊS RIOS - MATIAS BARBOSA (RJ/MG) - artigo publicado na Revista Brasileira de Geociências. 


\title{
Extrusão tectônica e transporte lateral de massa na porção central do cinturão Paraíba do Sul, seção Três Rios - Matias Barbosa (RJ/MG)
}

\author{
Letícia Constantino Vicente ${ }^{1}$, Nolan Maia Dehler ${ }^{2}$, Rômulo Machado ${ }^{3}$ \& Tiago da Rocha Karniol ${ }^{1}$
}

\begin{abstract}
Resumo Este trabalho discute a estrutura de uma seção no flanco norte da divergência estrutural do vale do rio Paraíba do Sul no Rio de Janeiro. No centro da estrutura, a foliação milonítica é vertical, a lineação de estiramento é horizontal e os indicadores cinemáticos sugerem movimentação destral (Domínio I). O estiramento vertical é secundário, e o encurtamento ortogonal ao plano de fluxo é evidenciado por estruturas em forma de tablete-de-chocolate. Para norte, ocorre um fragmento crustal (lasca tectônica) composto principalmente por ortognaisse (Domínio Paraíba do Sul - Domínio II). Este fragmento sobrepõe-se aos granulitos do Domínio Juiz de Fora (Domínio III). Ocorrem associadas à foliação principal dobras apertadas a isoclinais com eixos subparalelos a lineação de estiramento, além de dobras com superfície axial íngreme subparalelas às zonas de cisalhamento transpressivas e eixos paralelos à lineação de estiramento, que deformam a foliação milonítica. São encontrados tectonitos L e mullions subparalelos às charneiras dos dois grupos de dobras. No Domínio II, a foliação principal delineia em estereograma uma guirlanda com eixo de caimento baixo para NE, que é subparalelo a concentração da lineação de estiramento. Os indicadores cinemáticos sugerem movimento de topo para WSW, subparalelos e oblíquos ao cinturão Paraíba do Sul. A foliação e a lineação de estiramento apresentam orientação semelhante nos domínios II e III. Nos granulitos, estas estruturas obliteram a estruturação anterior. São registradas estruturas tardias, como zonas de cisalhamento dúcteis-rúpteis inversas com movimentação de topo para NW, e zonas de cisalhamento dúcteis transtrativas, sinistrais. A evolução estrutural (principal e tardia) da área é interpretada em termos de uma transpressão não-confinada. A partição da deformação durante convergência oblíqua e extrusão tectônica poderia explicar a simultaneidade entre os movimentos paralelos ao cinturão e os empurrões destrais para NW. A extrusão tectônica poderia explicar também a geração de tectonitos L e a ausência de lineações verticais nas zonas de cisalhamento transpressivas do cinturão.
\end{abstract}

Palavras-Chave: Cinemática, Transpressão, Extrusão, Cinturão Paraíba do Sul.

Abstract Tectonic extrusion and lateral mass transport in the inner portion of Paraiba do Sul belt, Três Rios - Matias Barbosa (MJ/MG) cross-section. This paper deals with the geometry and kinematics of structures, described along a section cross-cutting the northern limb of a NE-trending regional fan-like geometry. The structure occurs on the core of the Ribeira orogen in SE Brazil. Three structural domains were described, from south to north. In the domain I, the mylonitic foliation runs towards NE with sub-vertical to vertical dip. Stretching lineation is horizontal, and assymmetric structures suggest dextral transpressive motion in the core of the divergence (domain I). Tablet-of-chocolate boudinage suggests secondary vertical stretching and shortening orthogonal to the flow plane occurs. Northwards occurs a crustal slice composed mainly by orthogneiss, and minor metassediments and deformed granitoids, called Paraíba do Sul domain - or domain II. This slice tectonically overlies the granulitic rocks of the Juiz de Fora domain (domain III). Foliation in domain II delineates a guirdle on the stereoplot, with slowly ENE- plunging axes. Stretching lineation plunges slowly to $\mathrm{NE}$, parallel to the girdle axes. Tight to isoclinal folds with axis parallel to the stretching lineation occur within the mylonitic foliation. Slowly southward dipping mylonitic foliation (and associated folds) are deformed by open to tight, nearly upright extension-parallel folds with axial surfaces sub-parallel to the regional transpression zones. L-tectonites in deformed granitoids, and mullion structures parallel to the axes of both families of folds also were described. Shear-sense indicators suggest top-to-SWW shearing, sub-parallel and oblique to the orogenic trend, coeval with a NW-SE contractional component. Later structures are ductile-ruptile top-toNW thrusts and sinistral transtrative shear zones. The structural evolution of the area is interpreted in terms of regional dextral unconfined transpression. Our observations suggest that strain path partitioning during oblique extrusion and convergence may explain coeval parallel orogenic motion either in flat lying or steeply dipping shear zones, and WNW-directed dextral thrusts described in the deeper portions of the belt. Tectonic extrusion may also explain the presence of L-tectonites and the absence of vertical stretching lineation in the highly strained zones in the Paraíba do Sul Belt.

Keywords: kinematics, transpression, tectonic extrusion, Paraíba do Sul Belt.

1 - Pós-Graduação, Instituto de Geociências, USP, São Paulo, SP, Brasil. E-mail: lcvicente@usp.br, tikarniol@yahoo.com

2 - PETROBRAS, Rio de Janeiro, RJ, Brasil. E-mail: nolan@petrobras.com.br

3 - Instituto de Geociências, Universidade de São Paulo, São Paulo, SP, Brasil. E-mail: rmachado@usp.br 
INTRODUÇÃO A divergência estrutural do vale do rio Paraíba do Sul é uma estrutura regional em leque com direção NE que possui dois flancos, um a norte da zona de cisalhamento de Além-Paraíba, e outro a sul desta zona. Nos dois flancos da estrutura são encontrados milonitos que mergulham em direção à zona de cisalhamento. Esta estrutura tem sido descrita como uma estrutura transpressiva, desenvolvida em condições metamórficas de alto grau.

O estudo da tectônica do Cinturão Paraíba do Sul (CPS) - domínio central da Província Mantiqueira (sensu Hasui \& Oliveira 1984) - foi iniciado no final da segunda metade do século passado, com os trabalhos pioneiros sendo desenvolvidos principalmente por Rosier $(1957,1965)$ e Ebert $(1956,1968)$. Estes autores propuseram um modelo tectônico caracterizado por empurrões e nappes transportados para NW, presentes tanto nas porções internas do cinturão como mais para norte em direção ao antepaís (representado pelo Craton do São Francisco). Numa ótica mais atualística, este antepaís estaria contido na denominada Placa SanFranciscana (PSF) (Alkmin et al. 1993) (Fig. 1).

Os modelos estruturais disponíveis para a região hierarquizam as estruturas formadas durante a movimentação geral para norte em diferentes estágios na evolução tectônica do cinturão: (1) como estruturas precoces, $\mathrm{D}_{1}$ e $\mathrm{D}_{2}$ ou $\mathrm{F}_{1}$ e $\mathrm{F}_{2}$, que seriam anteriores aos movimentos transcorrentes, considerados tardios (ver Heilbron et al. 1995, dentre outros), (2) como estruturas não necessariamente mais antigas do que as transcorrências, podendo ser consideradas mesmo contemporâneas, pois, do ponto de vista geométrico e cinemático, apresentam um movimento coerente no âmbito de uma megaestrutura-em-flor positiva, relacionada com um regime transpressivo regional (Machado \& Endo1993 a e b, Ebert et al. 1993, dentre outros).

$\mathrm{O}$ grupo de estruturas compressivas tem sido associado, independentemente do modelo adotado, à deformação orogênica principal do cinturão (a exemplo do que foi proposto originalmente por Ebert). Fica evidente então que um dos aspectos fundamentais nesta questão, e que diferencia também os modelos propostos, é a interpretação do significado tectônico das estruturas de baixo ângulo, compressivas, e com movimentação de topo-para-NW. A caracterização de zonas de cisalhamento de baixo ângulo, associadas a movimentos oblíquos e subparalelos ao cinturão na região, evidencia a necessidade de uma reavaliação dos modelos tectônicos disponíveis (ver Ebert \& Hasui 1998, Dehler 2002 e Dehler \& Machado 2002).

São apresentados e discutidos neste trabalho os dados estruturais levantados em uma seção ao longo da BR-040, entre as cidades de Três Rios (RJ) e Matias Barbosa (MG), segmento este que corta quase ortogonalmente a aba norte da estrutura divergente do rio Paraíba do Sul. Os resultados obtidos apontam para um modelo tectônico de extrusão oblíqua vinculado regionalmente a uma movimentação destral do cinturão, em regime transpressivo, não-confinado.

\section{O CINTURÃo PARAÍbA do SUL NO RIO DE} JANEIRO $O$ arcabouço estrutural do cinturão Paraíba do Sul (na concepção de Ebert 1968, 1972), ou da faixa Ribeira (na concepção de Almeida 1973), localizado a SE de uma região menos deformada, denominada Craton do São Francisco, é dado por um arranjo estrutural de direção geral NE de zonas de cisalhamento contracionais Neoproterozóicas (Heilbron et al. 2004) (Fig. 2). Nas porções internas do cinturão, ocorre uma inversão regional que confere uma geometria sinclinorial assimétrica, denominada estrutura divergente ou divergência-em-leque do rio Paraíba do Sul (ver Ebert 1968 e Machado 1983). Constitui-se num arranjo divergente regional, formando um leque assimétrico de zonas de cisalhamento e plano axial de dobras, associado a movimentos ativos em condições metamórficas de alto grau (ver também Heilbron et al. 1991, Machado \& Endo 1993 a).

No flanco norte da estrutura ocorrem zonas contracionais com direção geral NE e mergulhos variados para SE, com movimentação frontal a oblíqua de topo para NW, em direção ao Craton do São Francisco (Heilbron 1993, Almeida 2001). No centro da estrutura ocorrem faixas de cisalhamento transpressivas, destrais (Dayan \& Keller 1989, Ebert et al. 1991, Dayan et al. 1993). A principal estrutura da região é a Zona de Cisalhamento de Além Paraíba (Almeida et al. 1975). A sul desta estrutura ocorre uma outra zona de cisalhamento (Zona de Cisalhamento Rio Santana-Ribeirão das Lajes) com foliação milonítica mergulhando para noroeste, associada à movimentação de topo para SW, seguida de deslocamento transtrativo destral e empurrões mais tardios com movimento de topo para SE (Machado 1983, Dehler et al. 2006).

Os modelos estruturais disponíveis na literatura para explicar a formação desta importante feição estrutural englobam concepções distintas, quais sejam: uma geométrica, num contexto de evolução tectônica polifásica, onde a estrutura divergente é considerada como uma mega-dobra tardia, com superfície axial vertical e eixo com caimento para NE, que deformaria as zonas de cisalhamento anteriores com movimentação de topo-para-NW (Heilbron et al. 1991, Almeida 2000); e outra envolvendo conceitos da tectônica transpressiva, onde a estrutura divergente representaria uma megaestrutura-em-flor positiva, cuja parte central seria ocupada pela Zona de Cisalhamento Dúctil de Além-Paraíba (Machado \& Endo 1993 a e b, Corrêa Neto et al. 1993, Dayan et al. 1993).

Os trabalhos sistemáticos de Ebert, realizados na região SE de Minas Gerais e região limítrofe com o Rio de Janeiro (sintetizados em Ebert 1956, 1968 e 1984), identificaram um sistema de empurrões e dobras com vergência para NW, considerados responsáveis pela estruturação principal do CPS na região (ver também Rosier 1957). Posteriormente, trabalhos baseados na análise geométrica regional das estruturas sugeriram um modelo tectônico polifásico para a estruturação principal do cinturão, onde as estruturas mais antigas $\left(D_{1}\right.$ e $\left.D_{2}\right)$ são associadas a movimentos compressivos 


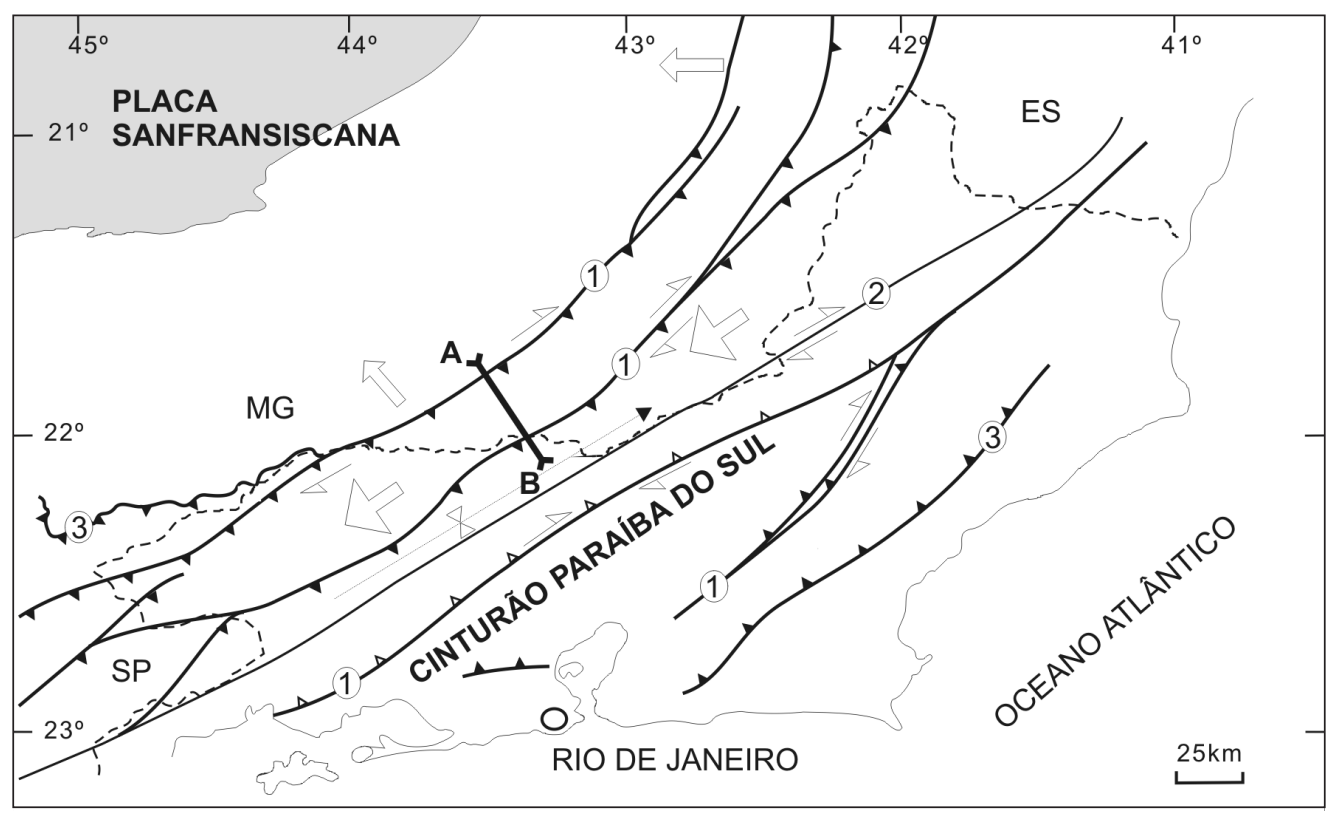

Figura 1 - Esboço estrutural do Cinturão Paraíba do Sul (CPS) no Estado do Rio de Janeiro e localização da Seção lito-estrutural levantada (A-B). Legenda: Seta maior- fluxo de deformação principal; Seta menor - fluxo de deformação secundário; (1) Zona de cisalhamento oblíqua com movimento indicado; (2) Zona de cisalhamento direcional com movimento indicado; (3) Zona de cisalhamento inversa (Modificado de Machado \&Demange 1994 e Silva et al. 2000).

correlatos àqueles propostos por Ebert (ver Machado 1983 e 1984, Heilbron 1993). A fase principal teria originado estruturas de baixo ângulo com vergência para NW, e seria também responsável pelo arcabouço tectônico regional (Heilbron et al. 1995). As estruturas tardias (atribuídas a uma terceira fase de deformação regional) seriam responsáveis pela geração de dobras abertas a cerradas com planos axiais verticais e eixos subhorizontais (Campanha 1981), bem como por zonas de cisalhamento dúcteis desenvolvidas sob condições metamórficas de alto grau e em regime transcorrente/ transpressivo destral (Braun 1972, comunicação oral).

Após a caracterização da transpressão destral em condições metamórficas de alto grau nas zonas de cisalhamento regionais (Dayan \& Keller 1989, Ebert et al. 1991, Corrêa Neto et al. 1993, Egydio-Silva et al. 2004), alguns autores propuseram o desenvolvimento contemporâneo entre as estruturas de baixo e de alto ângulo (Machado \& Endo 1993 a). Neste modelo tectônico - modelo de transpressão -, a contemporaneidade entre as zonas de cisalhamento de baixo e de alto ângulo implica numa articulação cinemática e partição da deformação, sob condições de convergência oblíqua, envolvendo componentes de encurtamento transversal e de cisalhamento simples paralelo ao CPS (Ebert et al. 1993b, Ebert \& Hasui 1998). Dehler \& Machado (2002), estudando o flanco sul da estrutura divergente, sugerem que o desenvolvimento das estruturas precoces teria ocorrido durante movimentação de topo para SSW, sob condições metamórficas de alto grau e concomitante com uma expressiva anatexia crustal no CPS. Consideram ainda que as estruturas precoces são associadas à extrusão tectônica para SSW de uma cros- ta continental parcialmente fundida. Estas estruturas foram superpostas por zonas de cisalhamento dúcteis transpressivas destrais, dobras e zonas de cisalhamento inversas, que teriam sido ativas durante o resfriamento e soerguimento progressivo do CPS na região (Dehler 2002). Sínteses regionais recentes sobre a evolução estrutural e tectônica do CPS a SE do CSF são encontradas em Trouw et al. (2000) e Heilbron et al. (2004).

APRESENTAÇÃO DOS DADOS Os dados geométricos e cinemáticos, levantados ao longo da seção ortogonal ao flanco norte da estrutura divergente regional serão descritos a seguir de sul para norte (ver Figs. 1 e 2). Os dados foram agrupados em domínios estruturais homogêneos e serão discutidos quanto à orientação de um elemento estrutural específico (Turner \& Weiss 1963).

Para definição desses domínios, adotou-se como critério o comportamento da foliação principal, uma vez que a lineação de estiramento e mineral não mostra variações significativas ao longo da seção. Os dados estruturais são apresentados em diagramas de Schimdt-Lambert, hemisfério inferior. Os indicadores cinemáticos foram descritos em seções paralelas à lineação de estiramento e ortogonais à foliação (seções paralelas ao plano XZ do elipsóide de deformação finita - ver Simpson \& Schmid 1983, Hanmer \& Passchier 1991).

Foram identificados três domínios estruturais ao longo da seção estudada (Fig. 2). O Domínio Estrutural I (DE I), localizado na parte sul da seção, é caracterizado por uma foliação milonítica vertical de direção NE-SW e uma lineação de estiramento direcional. O Domínio 


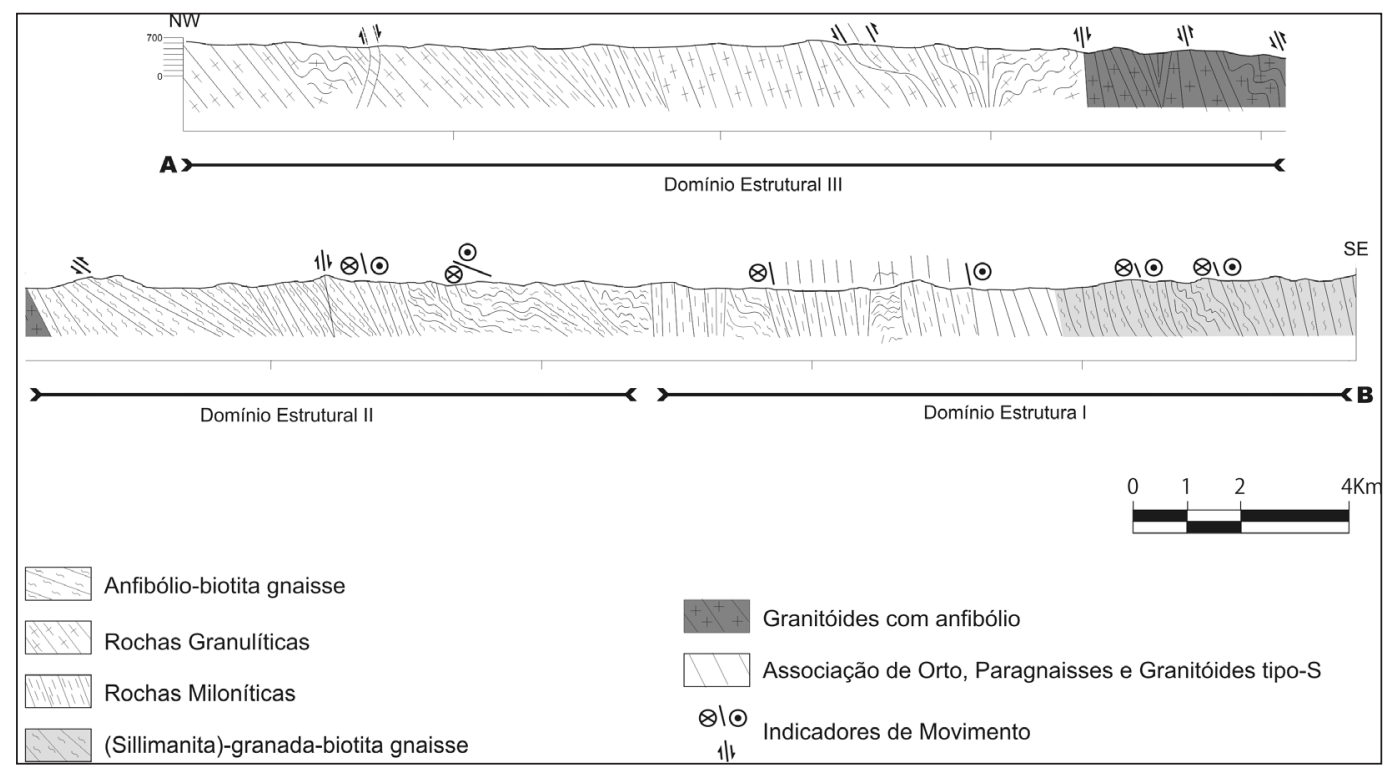

Figura 2 - Seção lito-estrutural entre Três Rios - Matias Barbosa (STMB). Ver discussão no texto.

Estrutural II (DE II), localizado na porção intermediária da seção, é caracterizado por uma foliação gnáissica e milonítica, com mergulho variável preferencialmente para SE, contendo uma lineação de estiramento mineral de caimento baixo para ENE. O Domínio Estrutural III (DE III), situado na porção norte da seção, caracterizase por foliação com mergulho moderado a alto para SE e lineação de estiramento mineral oblíqua, com caimento baixo para NE.

Domínio Estrutural I O Domínio Estrutural I (DE I) compreende uma associação de (anfibólio)-biotita ortognaisse, paragnaisses e granitóides, que foi influenciado pela Zona de Cisalhamento de Além-Paraíba (Fig. 2 - ver Almeida et al. 1975). As texturas e estruturas das rochas deste domínio são tipicamente miloníticas (ver também Dayan \& Keller 1989, Corrêa Neto et al. 1993, Egydio-Silva \& Mainprice 1999). Ocorrem ainda inclusões tectônicas de orto-granulitos nos milonitos ao longo do eixo principal da referida zona de cisalhamento.

As rochas do domínio apresentam em geral uma trama planar bem desenvolvida. A foliação milonítica é definida pela orientação preferencial de minerais estirados e recristalizados como biotita, feldspato, quartzo, anfibólio e sillimanita. Nas regiões mais deformadas, a foliação mostra-se paralela a um bandamento deformacional ou laminação tectônica, materializada por intercalações de bandas félsicas e máficas. Os minerais destas bandas apresentam granulação média a fina, principalmente nos níveis máficos. Ocorrem porções de granulação grossa, relativamente mais preservadas da deformação, formando pods ou bandas de composição granítica. Nos ortognaisses miloníticos observam-se também bandas com porfiroclastos estirados de feldspato (K-feldspato e plagioclásio). Em lâmina delgada, o K-feldspato mostra-se deformado e recristalizado (poligonizado). O plagioclásio exibe evidências de deformação plástica ou ruptura das maclas polissintéticas, bem como recristalização e poligonização nas suas bordas ou no interior dos porfiroclastos. O quartzo encontrase em geral poligonizado, exibindo ou não evidências de deformação. No primeiro caso mostra extinção ondulante e crescimento exagerado dos cristais, englobando muitas vezes cristais menores orientados da matriz. Ocorrem ainda microestruturas como ribbons de quartzo e K-feldspato (microclínio). Os anfibólios desses milonitos apresentam feições microestruturais sugestivas de deformação dúctil em fácies granulito (Egydio Silva et al. 2004).

Nas porções de deformação mais elevada, as bandas são contínuas por extensão métrica, conferindo aos gnaisses miloníticos um marcante aspecto listrado, com a estrutura sendo realçada pela presença de enclaves e/ou boudins de rochas cálciossilicáticas e anfibolitos alinhados, fortemente estirados e achatados no plano da foliação. Em projeção estereográfica, a foliação milonítica exibe concentração máxima dos pólos nos quadrantes NNW e SSE, resultando direção estatística N66 ${ }^{\circ} \mathrm{E}$, com mergulho subvertical (Fig. 3A).

A lineação de estiramento e mineral é em geral bem marcada no DE I, com exceção de locais onde a trama planar predomina em relação à trama linear (Stectonitos). A lineação é conferida pela orientação preferencial de feldspato, quartzo, anfibólio, biotita, sillimanita ou de agregados destes minerais. Esta estrutura é conferida também pela orientação do eixo maior de inclusões de cálciossilicáticas e anfibolitos. Em projeção estereográfica, a lineação tem orientação NE-SW

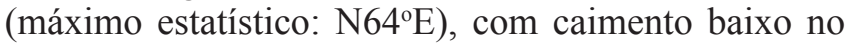
rumo NE (máximo: $6^{\circ}$ ), caracterizando-se geometricamente, em relação à foliação, como uma lineação direcional (Fig. 3B).

Nos setores em que a deformação é menos intensa, observa-se uma estrutura planar subhorizontal anterior que é deformada pelas zonas de cisalhamento subverticais. Nesses locais, ocorrem dobras com superfícies axiais subparalelas às paredes das zonas de cisalhamento com eixos de caimento baixo para NE. 


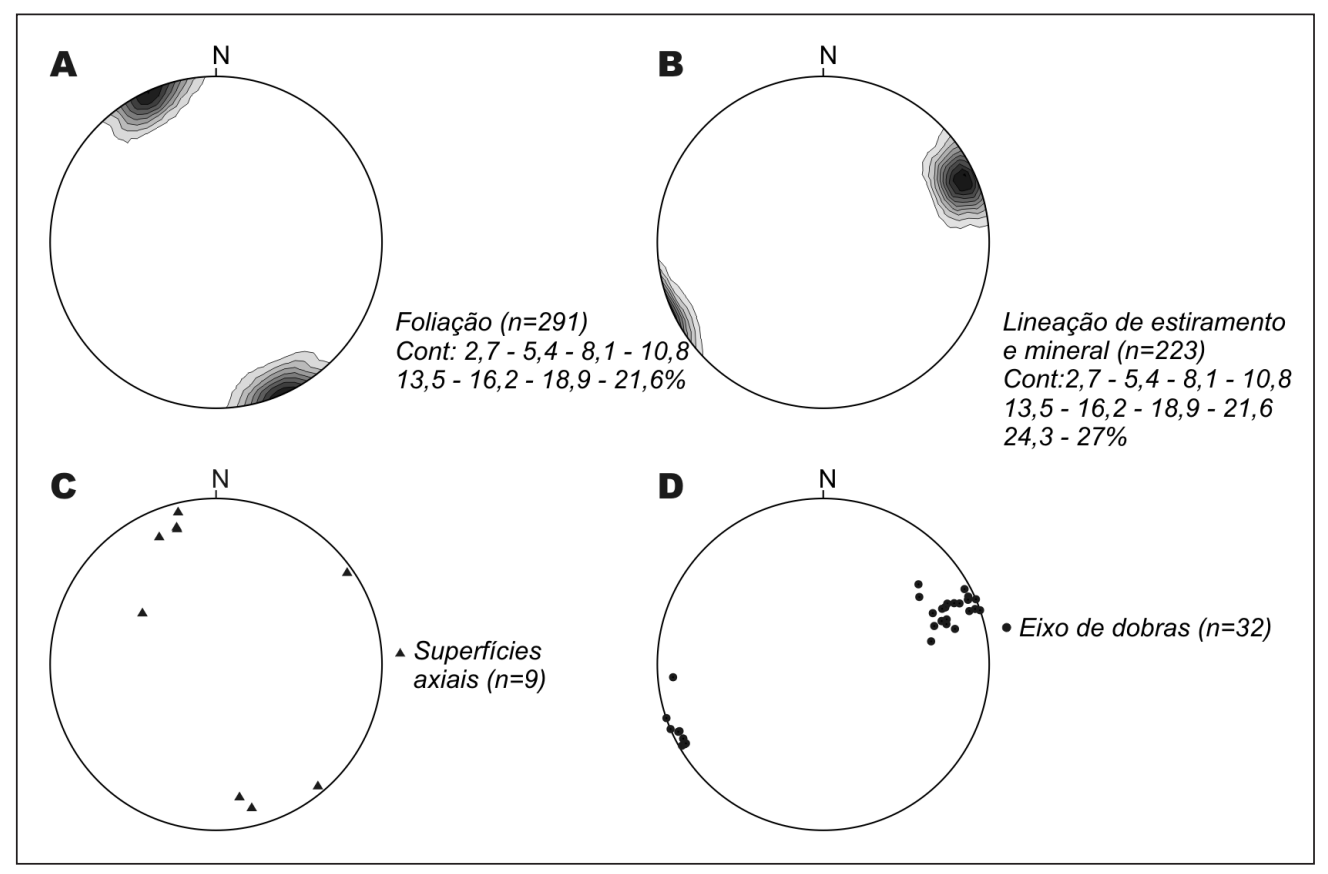

Figura 3 - Diagramas de projeção estereográfica (hemisfério inferior) dos elementos estruturais do Domínio Estrutural I (DE I) da Seção Três Rios - Matias Barbosa (STMB). A-Foliações medidas ao longo da STMB; B-Idem, para lineações; C-Superficie axial das dobras; D-Eixo das dobras. Para detalhes: ver discussão no texto.

São dobras simétricas, caracterizadas por perfis abertos a fechados, localmente isoclinais nas porções mais deformadas.

A foliação milonítica é plano-axial à estas dobras, e os eixos são sub-paralelos à lineação de estiramento mineral e de interseção. Em projeção estereográfica, os eixos destas estruturas são subhorizontais, de orientação geral $\mathrm{N} 64^{\circ} \mathrm{E}$, com superfícies axiais de direção NE-SW e mergulhos subverticais (Figs. 3D e C).

O domínio é caracterizado por uma foliação milonítica subvertical e lineação de estiramento horizontal, situação esta característica de zonas de cisalhamento com movimentação essencialmente direcional.

Os indicadores cinemáticos do domínio (porfiroclastos de feldspato com caudas assimétricas, sistemas de clastos tipo $\sigma$ e $\delta$, tramas compostas com superfícies S-C e inclusões rígidas rotacionadas), observados em plano horizontal, são compatíveis com movimentação destral (Fig. 7A).

Observam-se nos afloramentos dos milonitos boudins estirados em duas direções, vertical e horizontal, do tipo tablete-de-chocolate (Fig. 7B) que, juntamente com os S-tectonitos descritos, sugerem forte achatamento ortogonal ao plano de cisalhamento.

No DE I ocorre uma amplificação cinemática vertical das dobras que é acompanhada da diminuição progressiva do seu ângulo interflancos com as proximidades de zonas de cisalhamento, juntamente com a colocação de diques subhorizontais de leucogranitos (ver Dehler \& Machado 2002), sugerindo encurtamento horizontal ortogonal ao plano de cisalhamento e estiramento vertical, subordinado. Rosier (1957) atribuiu este forte achatamento das dobras à translação para NW das nappes relacionadas a Serra dos Órgãos. Em regiões de alta deformação são encontrados ultramilonitos e a simetria das estruturas é ortorrômbica e a trama é fortemente planar. Os dados estruturais (geométricos, cinemáticos e microtexturais) discutidos neste trabalho reforçam as proposições já apresentadas quanto à estruturação da zona de cisalhamento de Além-Paraíba (Dayan \& Keller 1989, Dayan et al. 1993, Corrêa Neto et al. 1993, Egydio Silva \& Mainprice 1999, Nummer 2001).

Domínio Estrutural II O Domínio Estrutura II (DE II) corresponde ao que tem sido denominado na literatura como Domínio Paraíba (ver Heilbron et al. 1995, Silva et al. 2000). Este domínio corresponde uma "lasca" crustal com mergulho geral para SE, sendo caracterizado por (anfibólio) - biotita ortognaisse acinzentado com sillimanita - granada - biotita gnaisses miloníticos e (anfibólio) - biotita granitóides foliados subordinados. A unidade ortognáissica, de composição granodiorítica a granítica, possui granulação média a grossa. A foliação principal, paralela a um bandamento composicional subhorizontal, pode apresentar ou não textura milonítica. Este bandamento é realçado pela presença de intercalações de níveis quartzo-feldspáticos com níveis máficos, ricos em anfibólio e biotita. A unidade é em geral homogênea e apresenta uma foliação bem pronunciada, definida pela orientação preferencial dos minerais félsicos e máficos, onde é comum a presença de textura porfiroclástica. Ocorrem inclusões/enclaves anfibolíticos e rochas calciossilicáticas, em geral boudinados. As primeiras apresentam dimensões métricas, e as últimas, 


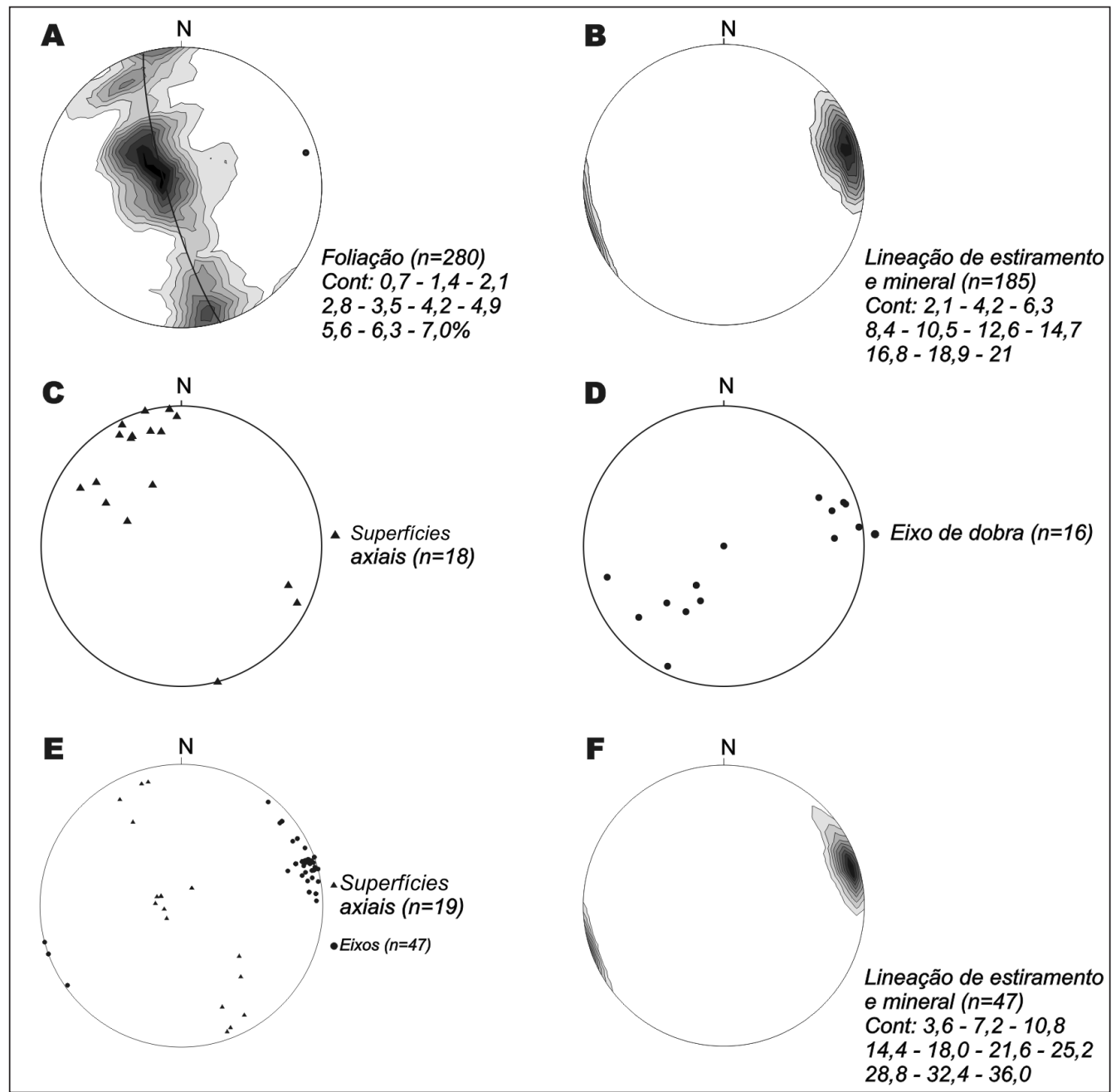

Figura 4 - Diagramas de projeção estereográfica (hemisfério inferior) dos elementos estruturais do Domínio Estrutural II (DE I I) da Seção Três Rios - Matias Barbosa (STMB). A-Conjunto de foliação medidas ao longo da STMB; B-Idem, para lineações; $C$-Superficies axiais de dobras; D- Eixos de dobras; E) Superficies axiais e eixos de dobras de um afloramento ; F) Lineação de estiramento e mineral do mesmo afloramento. Para detalhes: ver discussão no texto.

decimétricas.

A unidade de paragnaisses exibe uma foliação principal subparalela ao bandamento metamórfico, definida pela orientação preferencial dos minerais félsicos e máficos e lentes (ou bandas) de granitos hololeucocráticos e pegmatitos, além de bandas micáceas ricas em biotita e sillimanita. Os corpos graníticos e pegmatíticos são concordantes, subconcordantes e oblíquos à foliação gnáissica. Neste último caso, eles são controlados por zonas de cisalhamento dúcteis tardias. Estes granitos possuem foliação de forma muito pronunciada, caracterizada pela orientação das bordas dos grãos minerais constituintes, que se mostram paralelos a enclaves máficos microgranulares estirados. Em lâmina delgada, o plagioclásio e o K-feldspato mostram-se recristalizados e poligonizados, com deformação das maclas e extinção ondulante dos mesmos, havendo, entretanto, alguns cristais sem evidências de deformação. O quartzo, em contatos lobados, reentrantes e com deformação por migração de borda de grãos, sugere crescimento sob condições de alta temperatura. Alguns cristais apresentam extinção ondulante, enquanto outros não exibem evidências de deformação. Predomina um arranjo granonematoblástico a granolepidoblástico na escala microscópica. A foliação é definida pela orientação preferencial dos minerais máficos (biotita e anfibólio) e bordas de cristais de feldspato e quartzo. Nas porções mais deformadas, a orientação das bordas dos minerais é paralela à estrutura planar diferenciada ou a estrutura do tipo ribbons. A sillimanita ocorre como grãos prismáticos, alongados na foliação principal.

Em projeção estereográfica, a foliação principal possui geometria variável com seus pólos distribuindose segundo um círculo máximo. Nota-se, entretanto, o predomínio de uma foliação com mergulho de baixo ângulo para SE (Fig. 4A). A distribuição dos pólos desta foliação apresenta um máximo principal com atitude $\mathrm{N} 30^{\circ} \mathrm{E} / 12^{\circ} \mathrm{NW}$, e dois secundários: um com atitude $\mathrm{N} 78^{\circ} \mathrm{E} / 81^{\circ} \mathrm{NW}$ e outro, $\mathrm{N} 62^{\circ} \mathrm{E} / 83^{\circ} \mathrm{SE}$. Esta distribuição em guirlanda da foliação principal, juntamente com os 


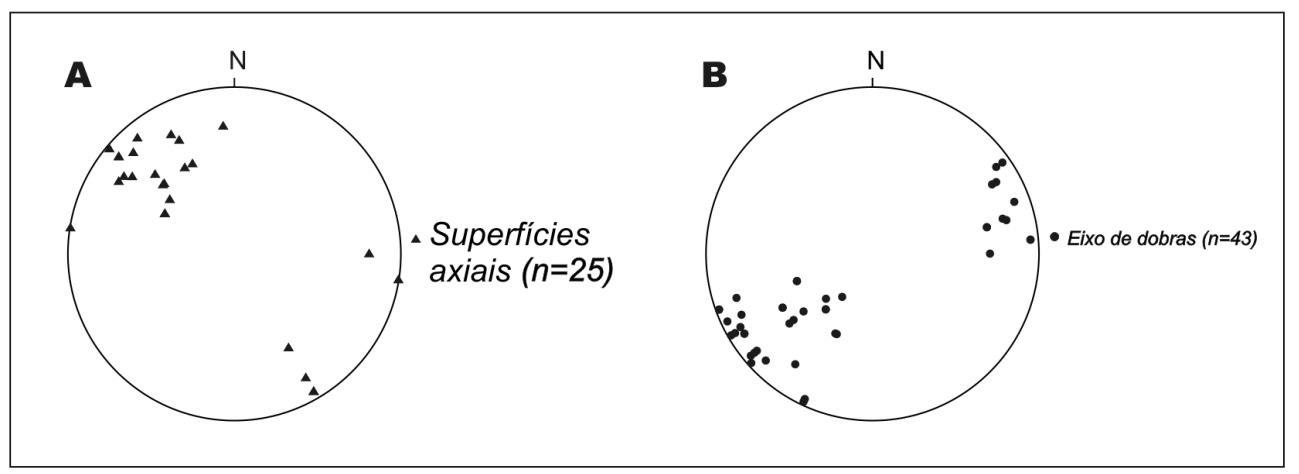

Figura 5 - Projeções estereográficas (hemisfério inferior) dos elementos estruturais de aftoramentos do Domínio Estrutural III (DE III) da Seção Três Rios - Matias Barbosa (STMB). A-Superficies axiais de dobras de um afloramento; B-Idem, para eixos de dobras. Para detalhes: ver discussão no texto.

dados de campo, sugere a existência de segmentos de dobras cilíndricas com eixo de caimento baixo (máximo: $8^{\circ}$ ) para o rumo $\mathrm{N} 74^{\circ} \mathrm{E}$.

As Figuras 4C e 4D representam estereogramas de dobras de um afloramento do DE II. A geometria ilustrada no diagrama é concordante com a da estrutura regional (ver Fig. 4A). No afloramento ocorrem dois grupos de dobras com estilos diferentes: um grupo mais antigo, caracterizado por dobras de perfis fechados a isoclinais, com superfícies axiais subhorizontais (recumbentes) e paralelas à foliação plano-axial, exibindo charneiras espessadas e flancos adelgaçados, por vezes rompidos, cujos eixos mostram-se paralelos a lineação de estiramento e mineral; o segundo grupo de dobras, com perfis abertos a fechados e charneiras arredondadas ou pouco desenvolvidas (agudas), superpõe-se geometricamente às dobras do primeiro grupo. Estas estruturas possuem superfícies axiais subverticais e com direção geral NE-SW. Na Figura 4E encontram-se representados os eixos e superfícies axiais destas estruturas, e na Figura 4F, a lineação de estiramento mineral. Os eixos das dobras, com orientação geral $\mathrm{N} 77^{\circ} / 6^{\circ}$, são subparalelos a lineação de estiramento. Associam-se a estes dois grupos de dobras estruturas lineares como mullions de dobramento.

Nesse domínio, a lineação de estiramento mineral é dada pela orientação preferencial de grãos de quartzo, feldspato, biotita, ou então por agregados destes minerais. Ocorrem corpos graníticos e enclaves máficos microgranulares estirados segundo à lineação e, localmente, L-tectonitos. Apesar da variação mostrada pela geometria da foliação, a lineação de estiramento mineral exibe atitude constante (direção NE-SW), com orientação geral $\mathrm{N} 74^{\circ} \mathrm{E} / 12^{\circ}$ (Fig. 4B), e é subparalela aos eixos das dobras que deformam esta mesma foliação.

As dobras superpostas à trama principal são interpretadas como registros de um componente de encurtamento ortogonal ao plano de foliação principal (Machado 1984, Heilbron 1993). Estas estruturas têm sido consideradas como de implantação tardia às zonas transpressivas de alto ângulo, geradas sob condições metamórficas em fácies anfibolito alto (Heilbron et al. 1995, Almeida 2000) ou em fácies granulito (Egydio Silva et al. 2002), ou então relacionadas à partição da deformação ocorrida em regime transpressivo (Ebert \& Hasui 1998). Dehler \& Machado (2002) descrevem ainda a associação destas estruturas com a intrusão de rochas graníticas na aba sul da divergência estrutural.

No contato com o domínio III são encontradas dobras com geometria diferente daquela descrita ao longo de todo o perfil, cuja superfície dobrada e lineação de estiramento mineral podem ser visualizadas nos diagramas das figuras 4E e 4F. Essas dobras são assimétricas para $\mathrm{N}$ e $\mathrm{W}$, e possuem foliação planoaxial subparalela ao referido contato. Os eixos dessas estruturas estão contidos na superfície axial e variam de paralelos (direção geral NE-SW) a oblíquos à lineação de estiramento (com caimento moderado a localmente íngreme para SW). Cabe salientar que esta variação é local e restrita a este importante contato.

A geometria geral do DII, como mostrado nos estereogramas, sugere a existência de um fragmento crustal com uma estrutura planar dominantemente de baixo ângulo. Esta foliação, entretanto, dispõe-se ao longo de uma guirlanda, cujo eixo coincide com os eixos das dobras tardias identificadas e com a lineação de estiramento no domínio, sugerindo que a direção do movimento principal durante o cisalhamento dúctil tenha sido paralela ao eixo da referida guirlanda e também das dobras tardias. As estruturas monoclínicas descritas nesse domínio são pares de foliações S-C e bandas de cisalhamento assimétricas (Fig. 7 C), porfiroclastos assimétricos do tipo $\delta$ e boudins assimétricos de leucogranitos rotacionados (Figs. $7 \mathrm{D}$ e E). Estas estruturas foram descritas segundo planos XZ do elipsóide de deformação, sendo demarcadas no campo com base numa forte lineação de estiramento mineral. Estes indicadores são consistentes entre si e sugerem durante a deformação principal uma movimentação de topo para SW. As estruturas tardias, superpostas à trama dúctil principal, manifestam-se como zonas de cisalhamento dúcteis discretas e dobras com superfície axial vertical. As zonas de cisalhamento pertencem a dois grupos 
principais: (1) zonas de cisalhamento com mergulho íngreme para SSE e movimentação sinistral com componente de abatimento do bloco S. São estruturas que podem alcançar dimensões métricas e geram muitas vezes dobras de arrasto expressivas na foliação principal; (2) zonas de cisalhamento com mergulho baixo para SE, associadas com planos discretos que podem conter ou não uma lineação de alto rake, caracterizada por uma rugosidade grossa. Estas zonas de cisalhamento podem associar-se a dobras levemente assimétricas para N. A presença de steps e dobras assimétricas associadas sugerem para estas estruturas movimentação de topo para NW. Ambas as zonas de cisalhamento controlam a colocação de mobilizados leucograníticos.

Domínio Estrutural III O Domínio Estrutural III (DE III) corresponde ao domínio tectônico Juiz de Fora de Heilbron et al. (1995). Este domínio encontra-se estruturalmente sotoposto ao DE II, correspondente ao domínio Paraíba do Sul.

Engloba uma associação de ortognaisses e paragnaisses que pode alcançar a fácies granulito. Localmente é marcante o aspecto milonítico destas rochas. Os granulitos podem ou não apresentar um bandamento pronunciado. Ocorrem associados com granada charnockitos foliados e paragnaisses migmatizados. Observam-se, localmente, relações magmáticas anteriores ao metamorfismo regional, com granulitos félsicos ou charnockitos homogêneos sendo intrusivos em gnaisses granulíticos, ou então englobando enclaves de granulitos máficos (ver também Heilbron et al. 1997). Estas rochas intercalam-se em ortogranulitos e anfibólio-biotita gnaisse cinzento (localmente róseo), de composição tonalítica a granítica, mostrando estrutura planar bem pronunciada e textura porfiroclástica, com anfibólio e feldspato estirados. Os paragnaisses possuem foliação paralela a um bandamento composicional bem marcado. Contêm localmente granada, cordierita, sillimanita e hiperstênio. Mostram-se às vezes mais homogêneos, com a foliação tectônica sendo definida pela orientação preferencial de feldspatos estirados. Em lâmina delgada, observa-se amplo desenvolvimento de microestruturas de alta temperatura como feições de recristalização por migração de borda de grãos, crescimento exagerado de cristais de quartzo, deformação dúctil e recristalização de feldspatos, além de ribbons de feldspato alcalino e quartzo.

Uma descrição petrográfica pormenorizada dos granulitos, envolvendo feições microtectônicas e relações texturais entre os seus diversos minerais constituintes, pode ser encontrada em Oliveira (1980, 1981), Duarte (1998), dentre outros.

A foliação principal do DE III apresenta direção geral NE-SW e mergulhos moderados a altos para SE. Nos diagramas, os pólos da foliação concentram-se em $\mathrm{N} 344^{\circ} / 24^{\circ}$ e apresentam atitude estatística N74 ${ }^{\circ} \mathrm{E} / 66^{\circ} \mathrm{SE}$ (Fig. 6 A). Notam-se variações no mergulho da foliação, compatíveis com padrões em leques de foliação ou de estruturas-em-flor positiva. Nota-se ainda que esta foliação é plano-axial de dobras com eixo de caimento suave para ENE.

A lineação de estiramento e mineral é materializada pela orientação de feldspatos, quartzo ou então de minerais hidratados como anfibólio e biotita. Esta estrutura é pouco evidente nos afloramentos desse domínio, tanto naqueles onde predominam tectonitos-S, quanto naqueles em que não é evidente a estrutura dos granulitos. Em projeção estereográfica, os dados da lineação concentram-se no setor NE do estereograma (máximo estatístico: $\mathrm{N} 82^{\circ} \mathrm{E} / 24^{\circ}$ ), exibindo variações de caimento ou rake, podendo mesmo mudar de quadrante, conforme pode ser observado no diagrama da figura $6 \mathrm{~B}$. Não é claro ainda o significado dessas variações, havendo a necessidade de estudos com maior detalhe. A relação geométrica dessa estrutura com a foliação permite classificá-la como uma lineação levemente oblíqua.

As dobras desse segmento apresentam em geral superfícies axiais de direção NE-SW, com mergulhos altos e eixos de caimento suave na mesma direção, mostrando-se localmente com relativa dispersão (Figs. $5 \mathrm{~A}$ e $5 \mathrm{~B}$ ). São dobras de perfis abertos a fechados, localmente isoclinais, com charneiras espessadas e pouco desenvolvidas.

A análise cinemática desse domínio é dificultada por fatores como a homogeneidade litológica dos afloramentos, a deformação relativamente baixa e o predomínio de uma forte trama planar sobre a trama linear nas principais zonas de cisalhamento encontradas.

As estruturas monoclínicas observadas (tramas S-C de foliação, boudins rotacionados, estruturas sigmoidais e, com menor confiabilidade, dobras assimétricas) sugerem movimento de topo para WSW, com movimentação destral em plano horizontal.

Em alguns afloramentos de granulitos observam-se planos de movimentos discretos, dúcteis, associados a uma lineação fina, com movimento de topo para $\mathrm{W}$, compatível com o movimento observado nas zonas de cisalhamento principais (Fig. 7 F). Estes movimentos são sugeridos a partir do deslocamento de marcador planar (seção de observação ortogonal à interseção entre o marcador e a zona de cisalhamento). Ao longo destas estruturas ocorre uma hidratação dos granulitos.

$\mathrm{Na}$ parte sul do domínio, próximo ao contato com o domínio II, ocorre em paragnaisses dobras com charneiras espessadas e eixos girados na direção da lineação de estiramento, sugerindo a existência de dobras em bainha. Para norte, a presença de padrões de foliação com disposição em leque, configurando estruturasem-flor positivas, sugere deformação em regime transpressivo. A existência de uma lineação de estiramento com rake intermediário para NE é compatível com movimentos também oblíquos neste domínio, embora, do ponto de vista mecânico, sejam esperados movimentos mais do tipo direcional.

Regimes Tectônicos e Evolução Estrutural Os dados estruturais aqui apresentados são consistentes com os de trabalhos anteriores (ver Dehler \& Machado 2002), tanto em termos da superposição geométrica 


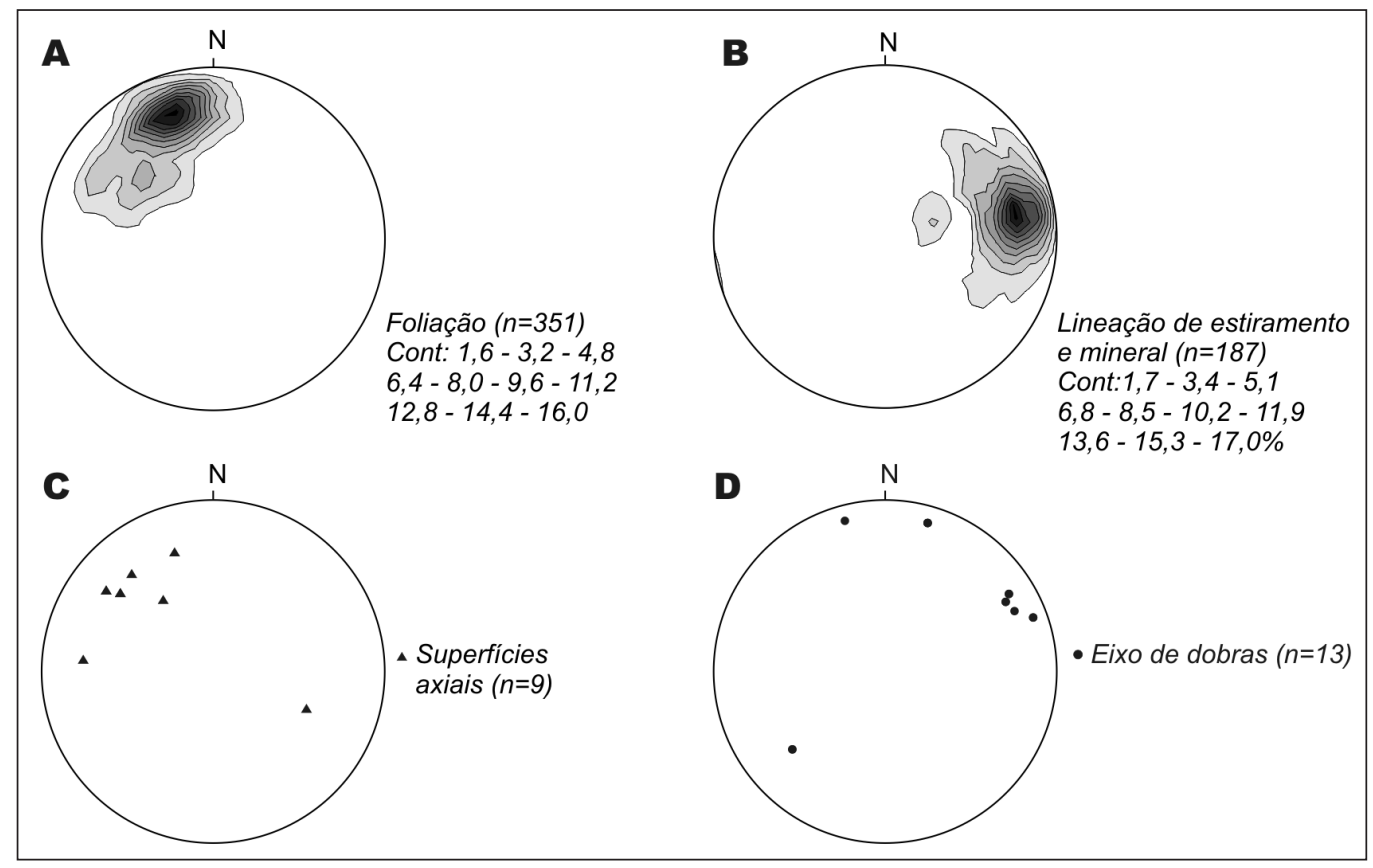

Figura 6 - Diagramas de projeção estereográfica (hemisfério inferior) dos elementos estruturais do Domínio Estrutural III (DE III) da Seção Três Rios - Matias Barbosa (STMB). A-Conjunto de foliação medidas ao longo da STMB; B-Idem, para lineações; C-Superficie axial de dobras; D-Eixo de dobras. Para detalhes: ver discussão no texto.

das estruturas como em relação à cinemática da deformação dúctil principal ativa em condições metamórficas de alto grau. Esses dados são também consistentes com o modelo de transpressão destral, não-confinada. Este modelo, previsto para um mesmo regime regional de deformação, contempla importantes movimentos de massa acomodados em planos de cisalhamento subhorizontais com movimentos paralelos a oblíquos ao trend orogênico (extrusão oblíqua/lateral). Tais movimentos são considerados concomitantes e associados geneticamente ao componente de encurtamento ortogonal ao orógeno.

A análise geométrica e cinemática das estruturas na seção estudada sugere a presença de dois estágios cinemáticos principais: um mais novo, caracterizado por regime transpressivo com componente direcional destral; e outro mais antigo caracterizado por movimento tangencial subparalelo ao CPS na região. O movimento mais antigo ocorreu em condições metamórficas de alto grau, e foi dirigido para WSW, com cinemática regional destral em relação à massa cratônica localizada a norte, a Placa Sanfranciscana (Dehler 2002). Por outro lado, os movimentos tardios teriam ocorrido sob condições mais drásticas de metamorfismo, em regime transpressivo, com partição da deformação em componentes coaxial (dobras e demais estruturas contracionais) (Ebert \& Hasui 1998) e não-coaxial (destral, concentrados nas zonas de cisalhamento de alto ângulo).

São descritos na literatura movimentos tangenciais paralelos ao trend orogênico, instalados em ambiente colisional oblíquo, de forma análoga ao que foi caracterizado no presente artigo no CPS (Ellis \& Watkinson 1987, Vauchez et al. 1993, Northrup \& Bur- chfiel 1996, dentre outros). No CPS, estes movimentos foram atribuídos à extrusão tectônica longitudinal resultante de colisão oblíqua ocorrida durante o Neoproterozóico (Dehler 2002).

Em resumo, os dados aqui discutidos são coerentes com os apresentados para o flanco sul da divergência estrutural (Dehler \& Machado 2002). Além disso, os autores sugerem a existência de uma fase inicial com movimento de topo para SW, resultante de extrusão tectônica oblíqua durante transpressão ocorrida no CPS (transpressão não-confinada). Estas estruturas são superpostas por zonas de cisalhamento dúcteis transpressivas destrais, zonas de cisalhamento inversas, dobras com eixos subhorizontais e superfícies axiais verticais. As zonas de cisalhamento transtrativas têm sido atribuídas ao colapso gravitacional tardio do orógeno (Heilbron et al. 1995). As observações efetuadas no presente trabalho não permitem considerações adicionais sobre a gênese destas estruturas, em função da complexidade que envolve a deformação extensional em cinturões orogênicos, notadamente sua relação com a deformação convergente regional (ver p.ex: Dewey et al.1988 e Doglioni 1996). Contudo, trabalhos recentes realizados na extremidade sul do CPS, na divisa de São Paulo com o Paraná, consideram que condições compressivas e transtrativas podem coexistir durante convergência num modelo de transpressão não-confinada (Dehler et al. 2007).

CONCLUSÕES As estruturas caracterizadas na aba norte da estrutura divergente do rio Paraíba do Sul sugerem um modelo evolutivo de deformação estrutural em dois estágios principais: um mais antigo, envolven- 


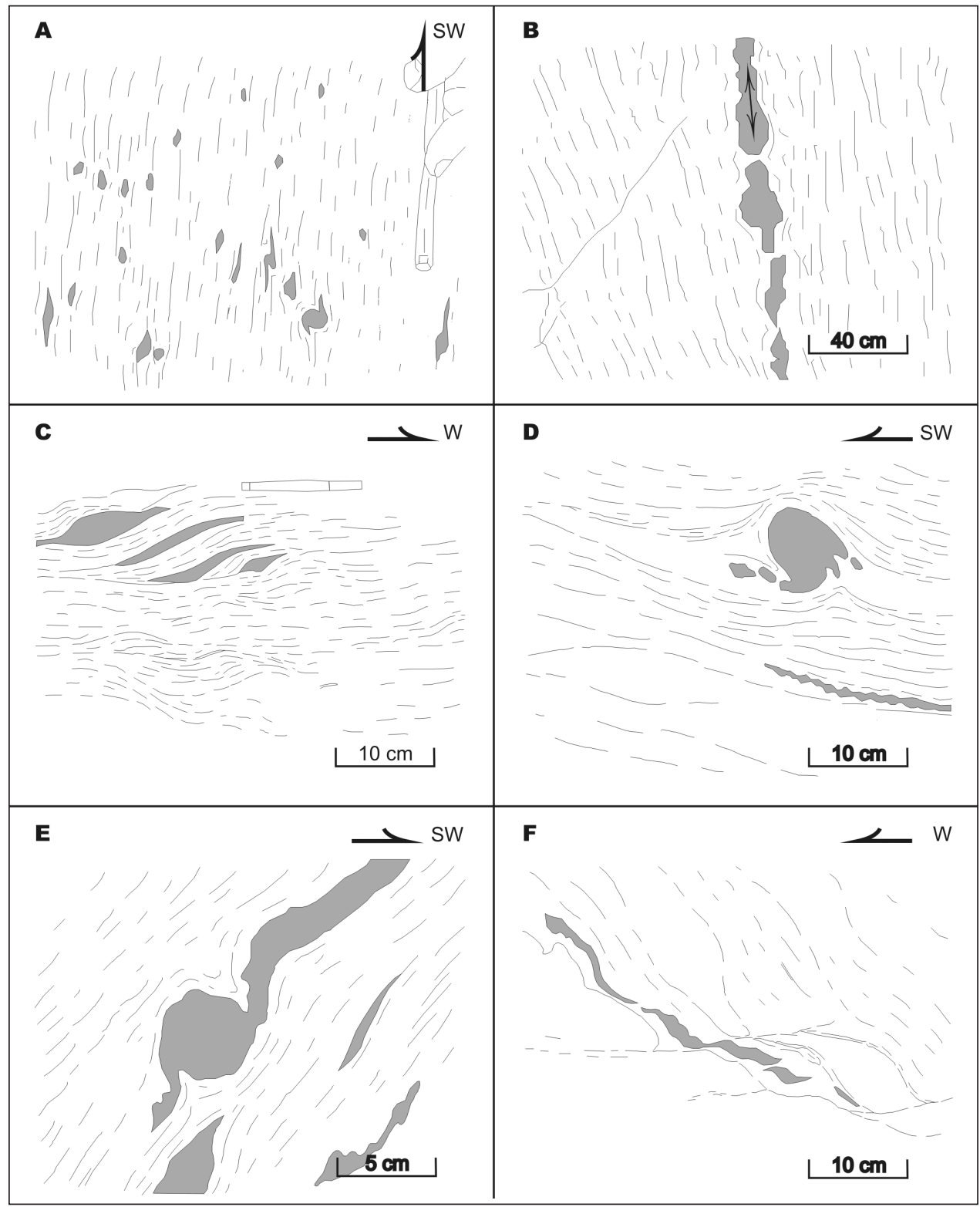

Figura 7 - Estruturas indicativas do sentido de cisalhamento: A-porfiroclastos de feldspatos assimétricos (plano de observação: horizontal); B- boudins estirados na direção vertical ( plano de observação: vertical); $C$ - Pares $S$ - $C$ de foliações $e$ bandas de cisalhamento extensionais (plano de observação: vertical); $D$ - boudin assimétrico de granada rotacionado (plano de observação: vertical) ; E- boudin assimétrico de leucogranito rotacionado (plano de observação: vertical); F- Zonas de cisalhamento discretas subhorizontais (plano de observação: vertical). O sentido de movimento está indicado nas figuras. Para detalhe: ver discussão no texto.

do movimento tangencial de topo para WSW, sob condições metamórficas de alto grau, responsável pelo emplacement oblíquo de um fragmento crustal (infracrustal) relativo ao Domínio II, correspondente ao Domínio Paraíba do Sul. Este estágio foi acompanhado pela extrusão tectônica para SW, em regime transpressivo, de fragmentos da crosta média/inferior das porções internas do Cinturão Paraíba do Sul na região. Durante este estágio, o cisalhamento não-coaxial subhorizontal produziu o giro das dobras internas para uma posição paralela a lineação de estiramento mineral. Esse movimento é compatível com a existência de empurrões oblíquos ao longo de planos de cisalhamento orientados NE-SW (topo para NW e componente direcional destral), descritos em diversos pontos do CPS; com o progresso da convergência oblíqua, a foliação subhorizontal anterior é afetada por dobras tardias, com eixos subparalelos à direção de movimento, zonas de cisalhamento transpressivas subverticais e zonas de cisalhamento inversas, dando origem às estruturas do estágio mais jovem. Ambas as famílias de estruturas são cinematicamente compatíveis, sugerindo sua coexistência durante pelo 
menos parte do período considerado da evolução tectônica do CPS. Num estágio mais avançado da convergência, as dobras tornam-se mais apertadas, favorecendo o movimento em zonas subverticais, e também de empurrões discretos. Zonas dúcteis extensionais, locais e discretas, deformam a estruturação principal, e encontram-se aparentemente desvinculadas do evento deformacional regional aqui descrito.

Os dados aqui apresentados, juntamente com os disponíveis na literatura (ver p.ex. Heilbron 1993), sugerem que os incrementos tardios da deformação principal tenham ocorrido pelo menos sob condições de fácies anfibolito alto, promovendo a hidratação generalizada dos granulitos ao longo de planos de movimentos discretos.

Finalmente, os dados estruturais discutidos su- portam para o segmento do CPS no Rio de Janeiro a existência de uma movimentação principal subparalela a oblíqua ao referido cinturão na região. Considerandose a Placa Sanfranciscana como referência (ver Dehler 2002), nota-se que esta movimentação é compatível com o deslocamento regional destral do Cinturão com relação à referida placa.

Agradecimentos Os autores agradecem à CPRM Serviço Geológico do Brasil, pelo apoio - durante e após - para a realização das atividades de campo, agradecem também à FAPESP (Proc. 02/12601-4), pelo suporte financeiro que permitiu a realização de parte dos trabalhos de campo, e, finalmente, ao CNPq (Proc. 300423/82-9, de R. Machado), pela concessão de uma bolsa de Produtividade em Pesquisa.

\section{Referências}

Almeida F.F.M., Amaral G., Cordani U.G., Kawashita K. 1973. The precambrian evolution of the South American cratonic margin south of Amazon river. In: E.M. Nairn \& F.G. Stehli (eds.) The Ocean Basins and Margins. New York, Plenun, p. 411-446.

Almeida F.F.M., Hasui Y., Carneiro C.D.R. 1975. O lineamento de Além-Paraíba. Anais Acad. Bras. Ciênc., 48:575.

Almeida J.C.H. 2000. Zonas de cisalhamento dúcteis de alto grau do Médio Vale do Rio Paraíba do Sul. Tese de Doutoramento, Instituto de Geociências e Ciências Exatas, Universidade Estadual Paulista, 190p.

Campanha G. 1981. O lineamento de Além-Paraíba na área de Três Rios, RJ. Rev. Bras. Geoc. 11:159-171.

Chauvet A. \& Séranne M. 1994. Extension-parallel folding in the Scandinavian Caledonides: implications for lateorogenic processes. Tectonophysics, 238:31-54.

Corrêa Neto A.V., Dayan H., Valença J.G., Rafael Cabral A. 1993. Geologia e estrutura da zona de cisalhamento do rio Paraíba do Sul entre Três Rios, RJ e Sapucaia, RJ. In: SBG, Simp. Geol. Sudeste, 3, Atas, p. 194-200.

Dayan H. \& Keller J.V.A. 1989. A zona de cisalhamento do Rio Paraíba do Sul nas vizinhanças de Três Rios, RJ: uma análise da deformação dada por algumas feições estruturais. Rev. Bras. Geoc., 19:494-506.

Dayan H., Corrêa Neto A.V., Valença J.G. 1993. A zona de cisalhamento do Rio Paraíba do Sul: Estudo de Padrões de orientação preferencial de eixos-c de quartzo. In: SBG, Simp. Nac. Est. Tect., 4, Anais, p. 339-342.

Dehler N.M. 2002. Extrusão tectônica oblíqua em regime transpressivo no Cinturão Paraibides, RJ. São Paulo, Tese de Doutoramento, Instituto de Geociências, Universidade de São Paulo, 161p.

Dehler N.M. \& Silva P.C.S. 2000. Projeto compilação geológica da Folha Volta Redonda (escala 1:250.000). São Paulo, CPRM, 16p. (Nota Explicativa).

Dehler N.M. \& Machado R. 2002. Análise Cinemática da aba sul da estrutura divergente do Rio Paraíba do Sul, na porção ocidental do estado do Rio de Janeiro. Rev. Bras. Geoc., 32:481-490.
Dehler N.M., Machado R., Fassbinder E. 2007. Shear structures in the Serra do Azeite shear zone, Southeastern Brazil: transtensional deformation during regional transpression in the Central Mantiqueira Province (Ribeira belt). Journ. South Am. Earth Sc., 23:176-192.

Dehler N.M., Machado R., Dehler H.R.S., Nummer A., Fassbinder E. 2004. Orogenic-parallel tangential shearing in convergent orogens: transient strain accommodating parallel flow during transpression and extrusion in the Paraíba do Sul belt, southeastern Brazil. In: Inter. Geol. Congr., 32, Abstracts, p. 96-1.

Dewey J.F., Holdsworth R.E., Strachan R.A. 1998. Transpression and transtension zones. In: R.E. Holdsworth, R.A. Strachan, J.F. Dewey (eds). Continental Transpressional and Transtensional Tectonics. London Geological Society, Special Publication, 135, p. 1-14.

Doglioni C. 1996. Geological remarks on the relationships between extension and convergent geodynamic settings. Tectonophysics 252:253-267.

Duarte B.P. 1998. Evolução tectônica dos ortognaisses dos complexos Juiz de Fora e Mantiqueira na região de Juiz de Fora, MG: geologia, petrologia e geoquímica. São Paulo, Tese de Doutoramento, Instituto de Geociências, Universidade de São Paulo, 280p.

Ebert H. 1968. Ocorrências de fácies granulíticas no sul de Minas Gerais e em áreas adjacentes em dependência da estrutura orogênica: hipóteses sobre sua origem. An. Acad. Bras. Ciênc., 40:215-229.

Ebert H. 1984. Os Paraibides entre São João del Rei, Minas Gerais, e Itapira, São Paulo, e a bifurcação entre Paraibides e Araxaides. Public. Soc. Bras. Geol. SP, Documento, 12:72-103.

Ebert H.D. \& Hasui Y. 1998. Transpressional tectonics and strain partitioning during oblique colision between three plates in the precambrian of south-east Brazil. In: R.E. Holdsworth, R.A. Strachan, J.F. Dewey (eds.) Continental transpressional and transtensional tectonics. London Geological Society, Special Publication,135,p. 231-252.

Ebert H.D., Hasui Y., Costa J.B.S. 1991. O caráter transpressivo do cinturão transcorrente rio Paraíba do Sul. In: 
SBG, Simp. Nac. Est. Tect., 3, Boletim de Resumos Expandidos, p. 139-141.

Ebert H.D., Hasui Y., Sartorato G., Almeida S.H., Costa J.B.S. 1993 a. Arcabouço estrutural e tectônica transpressiva das faixas móveis da borda sul e sudeste do cráton do São Francisco e da Sintaxe de Guaxupé. In: SBG, Simp. Nac. Est. Tect., 4, Anais, p. 166-171.

Ebert H.D., Neves M.A., Hasui Y., Szatmari P., Aires J.R. 1993 b. Evolução dos cinturões de cisalhamento entre os blocos São Paulo, Vitória e Brasília através da tectônica colisional oblíqua - uma modelagem física. In: SBG, Simp. Nac. Est. Tect., 4, Anais, p. 254-258.

Egydio-Silva M. \& Mainprice D. 1999. Determination of stress directions from plagioclase fabrics in high grade deformed rocks (Além-Paraíba shear zone, Ribeira fold belt, southeastern Brazil). Journ. Struc. Geol., 21:17511771.

Egydio-Silva M., Vauchez A., Bascou J., Hippert J.F. 2002. High temperature deformation in the neoproterozoic transpressional Ribeira Belt, southeast Brazil. Tectonophysics, 352:203-224.

Egydio-Silva M., Vauchez A., Raposo M.I.B., Jérome B., Uhlein A. 2004. Anisotropia de suscetibilidade magnética aplicada à análise tectônica em granulitos da faixa Ribeira(SE Brasil).In:SBG, ong.Bras.Geol.,42, Atas,cd

Ellis M. \& Watkinson A.J. 1987. Orogen-parallel extension and oblique tectonics: The relation between stretching lineations and relative plate motions. Geology, 15:10221026.

Hanmer S. \& Paschier C. W. 1990. Shear Sense Indicators: a review. Geological Survey of Canada Paper, 90-17,72 p.

Hasui Y. \& Oliveira M.A.F. 1984. A Província Mantiqueira - Setor Central. In: F.F.M. Almeida \& Y. Hasui (eds.) $O$ Pré-Cambriano do Brasil, São Paulo, Edgard Blücher, p.308-344.

Heilbron M. 1993. Evolução Tectônico-metamórfica da seção Bom Jardim de Minas (MG)-Barra do Piraí (RJ). Setor central da Faixa Ribeira. São Paulo, Tese de Doutoramento, Instituto de Geociências, Universidade de São Paulo, 268p.

Heilbron M., Machado R., Figueiredo M.C.H. 1997. Lithogeochemistry of Paleoproterozoic Orthogranulites from the Rio Preto (MG) - Vassouras (RJ) region, central Ribeira Belt, SE Brazil. Rev. Bras. Geoc., 27: 83-98.

Heilbron M., Valeriano C.M., Almeida J.C.H., Tupinambá M. 1991. A Megassinformal do Paraíba do Sul e sua implicação na compartimentação tectônica do setor central da Faixa Ribeira. In: SBG, Simp. Geol. Sudeste, 2, Atas, p. 519-527.

Heilbron M., Valeriano C.M., Valladares C.S., Machado N. 1995. A orogênese brasiliana no segmento central da Faixa Ribeira, Brasil. Rev. Bras. Geoc., 25:249-266.

Heilbron M., Pedrosa Soares A.C., Campos Neto M.C., Silva L.C, Trouw R.A.J., Janasi V.A. 2004. Província Mantiqueira. In: V. Mantesso-Neto, A. Bartorelli, C.D.R. Carneiro, B.B. Brito Neves (org.) Geologia do continente sul-americano, Beca, p. 203-235.

Machado R. 1983. Considerações sobre a estruturação tectônica divergente da porção ocidental do Estado do Rio de Janeiro. In: SBG, Simp. Reg. Geol., 4, Atas: p.135-145.
Machado R. 1984. Evolução Geológica, Análise Estrutural e Metamórfica da Região de Vassouras e Paracambi, Porção Ocidental do Estado do Rio de Janeiro. São Paulo, Tese de Doutoramento, Instituto de Geociências, Universidade de São Paulo, 196p.

Machado R. \& Endo I. 1993 a. Cinturão de Cisalhamento Atlântico: um exemplo de tectônica transpressiva neoproterozóica. In: SBG, Simp. Nac. Est. Tect., 4, Atas, p. 189-191.

Machado R. \& Endo I. 1993 b. Megaestrutura em flor positiva do vale do Rio Paraíba do Sul no Rio de Janeiro e suas implicações tectônicas regionais. In: SBG, Simp. Geol. Sudeste, 3, Atas, v. 1, p. 208-213.

Northrup C.J. \& Burchfiel B.C. 1996. Orogen-parallel transport and vertical partitioning of strain during oblique collision. Journ. Struc. Geol., 18:1231-1244.

Nummer A.R. 2001. Geometria e cinemática de alojamento do Maciço Granítico Arrozal, sudoeste do estado do Rio de Janeiro. São Paulo, Tese de Doutoramento, Instituto de Geociências, Universidade de São Paulo, 169 p.

Oliveira M.A.F. 1980. Petrologia das rochas granuliticas da Faixa Paraíba do Sul, Estados do Rio de Janeiro e Minas Gerais. Tese de Livre-Docência, Instituto de Geociências e Ciências Exatas, Universidade Estadual Paulista, 116 p.

Oliveira M.A. F. 1981. Granulitos da faixa Paraiba do Sul: caracteres químicos dos piroxênios e valores geotermobaromérticos. Rev. Bras. Geoc., 11:222-226.

Rosier G.F. 1957. A geologia da Serra do Mar entre os picos da Maria Comprida e do Desengano. Boletim da Divisão de Geologia e Mineralogia, 166 p.

Rosier G.F. 1965. Pesquisas geológicas na parte oriental do Estado do Rio de Janeiro. Boletim da Divisão de Geologia e Mineralogia, $222 \mathrm{p}$.

Silva L.C., Santos, R.A, Delgado, I.M., Cunha, H.C. (Coords.) 2000. Mapa Geológico do Estado do Rio de Janeiro. Rio de Janeiro, CPRM/DRM, escala 1: 400.000.

Simpson C. \& Schmid S.M. 1983. An evaluation of criteria to deduce the sense of movement in sheared rocks. Geological Society of America Bulletim, 94:1281-1288.

Teyssier C., Tikoff B., Markley M. 1995. Oblique plate motion and continental tectonics. Geology, 23:447-450.

Tikoff B. \& Teyssier C. 1994. Strain modeling of displacement-field partitioning in transpressional orogens. Journ. Struc. Geol., 16:1575-1588.

Trouw R.A.J., Heilbron M., Ribeiro A., Paciullo F.V.P., Valeriano C.M., Almeida J.C.H., Tupinambá M., Andreis R. 2000. The central segment of the Ribeira Belt. In: U.G. Cordani, E.J. Milani, A. Thomaz Filho, D.A. Campos (eds.) Tectonic Evolution of South America, Rio de Janeiro, p. 287-310.

Turner F.J. \& Weiss L.E. 1963. Structural Analysis of Metamorphic Tectonites. New York, McGraw Hill, 545 p.

Vauchez A., Babaie H.A., Babaei A. 1993. Orogen-parallel tangential motion in the Late Devonian-Early Carboniferous southern Appalachians Internides. Canadian Journal of Earth Sciences, 30:12.

Manuscrito A-1579 Aceito em 11 de julho de 2007 
ANEXO II - EXTRUSÃO TECTÔNICA DE GRANULITOS NA PORÇÃO CENTRAL DA PROVÍNCIA MANTIQUEIRA, SEÇÃO BARRA DO PIRAÍ - CONSERVATÓRIA, RJ - artigo submetido à Revista Brasileira de Geociências. 


\title{
[RBG] Agradecimento pela Submissão
}

\author{
1 mensagem
}

\section{Alberto Pio Fiori <fiori@ufpr.br>}

Para: Letícia Constantino Vicente <levicente@gmail.com>

Letícia Constantino Vicente,

Agradecemos a submissão do seu manuscrito "Extrusão tectônica de granulitos na porção central da Província Mantiqueira, seção Barra do Piraí - Conservatória, RJ" para Revista Brasileira de Geociências.

Através da interface de administração do sistema, utilizado para a submissão, será possível acompanhar o progresso do documento dentro do processo editorial, bastanto logar no sistema localizado em:

URL do Manuscrito:

http://ojs.c3sl.ufpr.br/ojs2/index.php/rbg/author/submission/11491

Login: Icvicente

Em caso de dúvidas, envie suas questões para este email. Agradecemos mais uma vez considerar nossa revista como meio de transmitir ao público seu trabalho.

Alberto Pio Fiori

Revista Brasileira de Geociências

Revista Brasileira de Geoci\&ecirc;ncias http://www.ser.ufpr.br/rbg 
Extrusão tectônica de granulitos na porção central da Província Mantiqueira, seção Barra do Piraí Conservatória, RJ.

Letícia Constantino Vicente $^{1}$, Rômulo Machado ${ }^{2}$, Tiago da Rocha Karniol ${ }^{1}$

1 - Pós-Graduandos no Programa de Pós-Graduação em Geoquímica e Geotectônica do Instituto de Geociências da Universidade de São Paulo. Rua do Lago 562, Cidade Universitária, São Paulo/SP. CEP: 05508-900. E-mail: lcvicente@ usp.br, tikarniol@yahoo.com

2 - Instituto de Geociências da Universidade de São Paulo e Bolsista Pesquisador do CNPq. Rua do Lago 562, Cidade Universitária, São Paulo/SP. CEP: 05508-900. E-mail: rmachado@usp.br

6304 palavras

8 figuras 


\section{Extrusão tectônica de granulitos na porção central da Província Mantiqueira, seção Barra do Piraí - Conservatória, RJ.}

\section{RESUMO}

O presente trabalho trata da análise estrutural de uma seção entre Barra do Piraí e Conservatória, porção SW do Estado do Rio de Janeiro. A seção estudada situa-se na aba norte da estrutura divergente da Zona de Cisalhamento do Rio Paraíba do Sul, segmento central da Província Mantiqueira. Engloba rochas gnáissicas e granulíticas milonitizadas, correspondentes às unidades Paraíba do Sul, Quirino e Juiz de Fora. Foram reconhecidos cinco domínios estruturais (I a V), todos com foliação na direção NE-SW. O domínio estrutural I é marcado por uma foliação vertical e lineação direcional. O domínio II apresenta foliação com caimento baixo a moderado para NW e lineação predominantemente de mergulho, seguido pelos domínios III e IV, marcados, respectivamente, por uma foliação subvertical e lineação subhorizontal, e foliação de baixo ângulo de mergulho para SE e lineação oblíqua para sul. O domínio estrutural V é semelhante aos domínios I e III, sendo porém comum a ocorrência de dobras com eixos e planos axiais paralelos à foliação e lineação. Os indicadores cinemáticos nos domínios I, III e V são compatíveis com movimento destral e, no domínio IV, com movimento de topo para norte. Em todos os domínios observam-se estruturas contracionais coexistentes com as estruturas tipicamente transcorrentes. A evolução estrutural da área é interpretada como resultante de deformação em regime transpressivo não-confinado, com movimentação regional destral e extrusão localizada associada à partição espacial e temporal da deformação.

Palavras-chave: Zona de Cisalhamento do Rio Paraíba do Sul, transpressão não-confinada, extrusão

\section{ABSTRACT TECTONIC EXTRUSION OF GRANULITES ON THE BARRA DO PIRAÍ - CONSERVATÓRIA CROSS-SECTION, CENTRAL PORTION OF MANTIQUEIRA PROVINCE}

This work structurally analyzes one cross-section measured in the north portion of the divergent structure of the Paraíba do Sul River Shear Zone, central region of the Mantiqueira Province. It extends from Barra do Piraí town to Conservatória district, both in Rio de Janeiro State. It encompass milonitized gnaissic and granulitics rocks from Paraíba do Sul, Quirino and Juiz de Fora units, all described in scientific literature. Five structural domains were recognized (I to V), all of them with NE-SW direction of foliation. The structural domain I is characterized by vertical foliation and directional lineation. Domain II has intermediate to low NW dip foliation and mostly down-dip lineation, followed by III and IV. Domain III is distinguished by subvertical foliation and subhorizontal lineation, while domain IV has low SE dip SE and intermediate lineation towards south. The structural domain V is similar to domains I and III, differing in its greater number of folds, which present axes and axial surfaces parallel to the lineation and foliation. Kinematics indicators of domains I, III and V are compatible with dextral shear, while domain IV suggest top-to-N movements. Coexistent contractional and typically strike-slip structures are observed in all domains. The structural evolution of the studied area is interpreted as a result of deformation in a non-confined transpressive system, with dextral regional movement and local extrusions, which are related to spatial and temporal partitioning deformation.

Key-words: Paraíba do Sul River Shear Zone, non-confined transpression, extrusion

\section{INTRODUÇÃO}

A Zona de Cisalhamento do Vale do Rio Paraíba do Sul é uma importante estrutura tectônica regional da região sudeste do Brasil que situa-se na chamada Província Mantiqueira Central (Almeida et al. 1977, Almeida \& Hasui 1984). Esta região tem sido objeto de estudos de pesquisadores desde a metade do século passado, sendo os pioneiros Rosier (1957 e 1965), Ebert (1968), entre outros. A partir de então, os modelos tectônicos propostos para explicar o arcabouço estrutural da região têm considerado para esta estrutura uma implantação tardia (Machado 1983, Heilbron 1993, Heilbron et al. 1991) ou precoce (Machado \& Endo 1993a, Dehler 2002), na história evolutiva do cinturão.

Recentemente, inúmeros autores têm reconhecido a importância de regimes transpressivos na deformação de orógenos modernos, como por exemplo as falhas Great Sumatran, San Andréas, Alpina, entre outras, tornando-se uma hipótese plausível para explicar o arcabouço tectônico de orógenos antigos, onde a complexidade das estruturas dificilmente seria explicada sob condições de deformação envolvendo somente cisalhamento puro ou cisalhamento simples. Além da combinação destes dois mecanismos, existem outros fatores que influenciam na estruturação final de uma zona de deformação, como a ordem de nucleação de diferentes estruturas, partição espacial e temporal da deformação, profundidade na zona transpressiva e a relação entre as deformações finita e incremental.

Este trabalho trata da geologia estrutural de uma fração do Cinturão Ribeira, correspondente ao flanco norte da estrutura divergente da calha do rio Paraíba do Sul, na porção sudoeste do Estado do Rio de Janeiro, ao longo da seção Barra do Piraí - Conservatória. Esta estrutura é caracterizada, em geral, por 
gnaisses e granulitos milonitizados, com foliações que mergulham em direção à zona de cisalhamento principal.

Dessa forma, a proposta principal deste trabalho, além da caracterização geométrica e cinemática ao longo da referida seção, é avaliar os dados obtidos com base nas modelagens tectônicas em regimes transpressivos (Sanderson \& Marchini 1984, Fossen et al. 1994, Tikoff \& Teyssier 1994, Robin \& Cruden 1994, Jones et al. 1997, Dutton 1997, Jiang et al. 2001, entre outros), comparar os resultados com os modelos estruturais/tectônicos regionais existentes e discutir a influência da Zona de Cisalhamento do Vale do Rio Paraíba do Sul com as regiões adjacentes.

\section{CONTEXTO TECTÔNICO REGIONAL}

A área estudada situa-se no segmento central da Província Mantiqueira (Almeida et al. 1977, Almeida \& Hasui 1984), que se refere ao trecho da costa do Atlântico Sul afetado pelo Ciclo Brasiliano/PanAfricano (figura 1). Os trabalhos presentes na literatura descrevem-no, de maneira geral, como resultado da colisão oblíqua entre blocos crustais durante a formação do supercontinente Gondwana Oeste (Almeida et al. 2000). Segundo os autores, a colagem brasiliana (700-500 Ma), marcada nessa região por empurrões em direção ao Cráton do São Francisco, foi instalada sobre crosta arqueana, retrabalhada durante a Orogenia Transamazônica (2150-1900 Ma).

Figura 1 - Contexto geotectônico regional e mapa geológico da porção SW do Estado do Rio de Janeiro, com a localização da seção Barra do Piraí - Conservatória (RJ). 1 - Depósitos colúvio-aluvionares; 2 - Formação Resende; 3 - Intrusões alcalinas; 4 - Granitóides tipo-I, tardi a pós-orogênicos; 5 - Granitóides tipo-I, pré a sinorogênicos; 6 - Granitóides tipo-S, pré a sinorogênicos; 7 - Granitóides tipo-S, pré a sinorogênicos do Terreno Embu; 8 - Complexo Embu; 9 - Grupo Andrelândia; 10 - Complexo Paraíba do Sul; 11 - Suíte Quirino; 12 - Complexo Juiz de Fora; 13 - Zonas de cisalhamento; 14 - Rios. RJ - Rio de janeiro, BM Barra Mansa, VR - Volta Redonda, BP - Barra do Piraí, Co - Conservatória, Vl - Valença, Vs - Vassouras, PS - Paraíba do Sul, TR - Três Rios, MB - Matias Barbosa. Fonte: Schobbenhaus et al. (2004), Folha Rio de Janeiro (SF23).

Entre os modelos estruturais existentes para a região, destaca-se o modelo de deformação polifásico (Machado 1983 e 1984, Heilbron 1993, Heilbron et al. 1995 e 1998), onde o arcabouço final da deformação foi dado, inicialmente, por duas fases de deformação contínuas, responsáveis pelo desenvolvimento da foliação e bandamento regional, dobras isoclinais assimétricas e empurrões direcionados a NW em regime de deformação coaxial. Essa fase é considerada concomitante com metamorfismo em fácies anfibolito superior. Estas estruturas foram sobrepostas por uma terceira fase de deformação, caracterizada por dobras abertas a fechadas e zonas de cisalhamento de alto ângulo, responsáveis pela estruturação geral NE-SW do cinturão, sob condições metamórficas em fácies anfibolito intermediária. Os autores descrevem ainda uma quarta fase, representada principalmente por dobras de perfis abertos e orientação ortogonal à orientação geral das estruturas descritas, que são de difícil reconhecimento em escala de afloramento.

Este modelo evoluiu para um modelo de duas fases de deformação, mantendo-se, no entanto, a proposta de uma vergência inicial para NW, seguida por transcorrências acomodadas em zonas de cisalhamento (Almeida 2000, Petternel et al. 2005). Nesses trabalhos, são descritos, além dos empurrões para NW, movimentos oblíquos registrados por lineações de estiramento e mineral de rake moderado. Segundo Almeida (2000), existe uma defasagem de 30 Ma entre os dois regimes.

Outros modelos assumem uma colisão oblíqua E-W, resultando em um ambiente de deformação transpressiva (Ebert et al. 1991 e 1993a, Ebert \& Hasui 1998, Ebert 2005, Dehler 2002, Dehler \& Machado 2002). Estes modelos consideram que o progressivo encurtamento e espessamento da crosta, em deformação predominantemente compressiva, fizeram com que os deslocamentos ao longo de zonas de cisalhamento dúcteis de baixo ângulo fossem substituídos ou articulados principalmente por zonas de cisalhamento transcorrentes de alto ângulo, paralelas à estruturação geral do cinturão. Desse modo, tal modelo descreve dois estágios de deformação progressiva contínua, causada por colisão oblíqua de placas, que resultaram em uma geometria transpressiva no estágio finito de deformação.

Os autores descrevem uma alternância entre as regiões com uma tectônica predominantemente contracional ou transcorretnte, como resultado da partição regional da deformação. O reconhecimento de estruturas tipicamente compressivas, assim como dados de microestruturas (Egydio-Silva et al. 2005) sugerem que os dois regimes de deformação coexistiram em várias escalas e que a deformação por cisalhamento puro foi o regime tectônico mais importante (Egydio-Silva \& Mainprice 1999). Este modelo 
corresponde a um modelo deformacional transpressivo que contempla uma evolução tectônica simples sob condições metamórficas na fácies granulito, com metamorfismo retrógrado na fácies anfibolito superior (Correa Neto et al. 1993).

\section{A Zona de Cisalhamento do Rio Paraíba do Sul}

O Cinturão Ribeira é marcado por uma série de zonas de cisalhamento dúcteis verticais, de direção NE-SW, que apresentam movimentação em geral destral. Este cinturão foi definido como um cinturão de cisalhamento transpressivo (Cinturão de Cisalhamento Atlântico) (Machado \& Endo 1993a) e dividido em dois sistemas principais: o Sistema de Cisalhamento Paraíba do Sul e o Sistema de Cisalhamento Dom Feliciano. Ambos os sistemas são constituídos por zonas de cisalhamento dúcteis de várias ordens, com mergulhos em geral de alto ângulo, que se articulam lateral e verticalmente e conferem em mapa um padrão estrutural anastomosado. Nesse contexto, a Zona de Cisalhamento do Rio Paraíba do Sul é uma das estruturas tectônicas regionais mais expressivas do cinturão (mais de $25 \mathrm{~km}$ de largura) e encontra-se associada no Rio de Janeiro com rochas de alto grau, incluindo granulitos, em particular na parte norte do Estado. Caracteriza-se pela disposição divergente das estruturas em relação à zona central, esta coincidente com a calha do referido rio (Ebert 1968, Machado 1983, Machado \& Endo 1993 a, b).

Essa estrutura parece se conectar regionalmente com outras zonas de cisalhamentos do cinturão, razão pela qual alguns autores têm denominado o sistema de lineamentos Além Paraíba-Cubatão-Lancinha. O lineamento de Além-Paraíba é sua principal estrutura, que, somente no Estado do Rio de Janeiro, estendese por aproximadamente $240 \mathrm{~km}$, sendo caracterizado na região central por rochas blastomiloníticas (Almeida et al. 1975, Campanha 1980 e 1981). Sadowski (1983) sugere para esta estrutura um deslocamento de, no mínimo, $40 \mathrm{~km}$.

Alguns autores a consideram como uma estrutura sinclinorial relacionada à terceira fase de dobramento, no modelo polifásico de deformação regional (Machado 1983 e 1984). Heilbron et al (1991 e 1995) e Heilbron (1993) denominaram a estrutura de Megassinforma do Rio Paraíba do Sul, caracterizada por uma zona de cisalhamento situada na sua zona de charneira.

A divergência característica, onde as estruturas a NW do vale do Rio Paraíba do Sul mergulham para SE, e as estruturas a SE, mergulham para NW, e na zona central são verticais, levaram alguns autores (Machado \& Endo 1993b, Ebert et al. 1993b, Ebert et al. 1995, Correa neto et al. 1993) a descrever a zona de cisalhamento e a estrutura regional como uma mega-estrutura em flor positiva, resultante da deformação em um ambiente transpressivo (Dayan \& Keller 1990, Correa Neto et al. 1993, Machado \& Endo 1993a).

Egydio-Silva (1996) sugere que essas zonas de cisalhamento destrais no cinturão estão relacionadas a escape tectônico da litosfera em direção a SW, na terminação de um bloco rígido durante uma colisão continental, de acordo com o modelo de Vauchez et al (1994).

Dehler \& Machado (2002) e Dehler (2002), num estudo na aba sul da estrutura, referem-se à mesma como uma divergência em leque, formada durante um segundo estágio de deformação contínua de caráter transpressivo (ver também Dehler et al. 2006).

Alguns autores têm relacionado as zonas de cisalhamento de baixo ângulo aos movimentos oblíquos subparalelos ao cinturão, condição esta que impõe a necessidade de uma reavaliação dos modelos tectônicos anteriores (ver Ebert \& Hasui 1998, Dehler 2002 e Dehler \& Machado 2002).

\section{MATERIAIS E MÉTODOS}

Para os trabalhos de campo, foram utilizados os materiais habituais de coleta de dados geológicos, como martelo, bússola, lupa, GPS, caderneta de campo, câmera digital, cartas topográficas, imagens de satélite etc. Foi realizada uma descrição e hierarquização das estruturas tectônicas segundo os procedimentos descritos em Hobbs et al. (1976). Paralelamente, foi realizada a coleta de dados geométricos e cinemáticos das estruturas, os quais foram tratados em diagramas de projeção estereográfica tipo Schmidt-Lambert, hemisfério inferior, gerados a partir do programa Stereonet for Windows. Foram também obtidas imagens das estruturas de campo, que são apresentadas ao longo do trabalho e visam auxiliar o leitor na compreensão do quadro estrutural sugerido para a região.

Paralelamente, foram coletadas amostras orientadas visando descrição petrográfica e microtectônica em seções delgadas, orientadas segundo o plano XZ do elipsóide de deformação finita.

A análise geométrica das estruturas seguiu os procedimentos descritos em Turner \& Weiss (1968), que consistem basicamente na definição de domínios estruturais homogêneos quanto à orientação de um determinado elemento estrutural, planar ou linear, e que serão descritos a seguir a partir da cidade de Barra do Piraí em direção à Conservatória, ou seja, de sudeste para noroeste. 


\section{APRESENTAÇÃO DOS DADOS}

A seção estudada estende-se desde a cidade de Barra do Piraí até as proximidades de Conservatória, ao longo da rodovia RJ-137, porção sudoeste do estado do Rio de Janeiro. Possui extensão de cerca de 25 km, com direção NW-SE, ortogonal à estruturação geológica da área.

Compreende uma associação de rochas gnáissicas orto e paraderivadas, xistos e quartzitos metamorfisados na fácies anfibolito superior, além de granulitos félsicos e máficos intercalados (figura 2). Esse grupo de litotipos corresponde aos Complexos Paraíba do Sul e Juiz de Fora e a Suíte Quirino, ilustrados na figura 1.

Figura 2 - Seção geológico-estrutural entre a cidade de Barra do Piraí e o distrito de Conservatória. 1 (muscovita)-biotita gnaisse sienogranítico; 2 - quartzito feldspático; 3 - sillimanita-muscovita-biotita-quartzo xisto; 4 - biotita gnaisse quartzoso; 5 - (granada)-biotita gnaisse com anfibólio; 6 - (Clinopiroxênio)anfibólio-biotita gnaisse tonalítico; 7 - Granulito félsico; 8 - Granulito máfico; 9 - Indicadores cinemáticos.

\section{Domínio estrutural I}

O domínio estrutural I localiza-se no extremo sudeste da seção, próximo à cidade de Barra do Piraí, conforme indicado na figura 2. É composto, de maneira geral, por uma unidade de (muscovita)-biotita gnaisse de composição sienogranítica, contendo intercalações subordinadas de sillimanita-muscovita-biotitaquartzo xisto e biotita gnaisse quartzoso.

A unidade de gnaisses sienograníticos exibe estrutura planar formada pela orientação de minerais micáceos e cristais de quartzo estirados, além de um bandamento composicional milímétrico, marcado pela segregação de minerais máficos e félsicos. Observam-se também injeções pegmatíticas centimétricas, paralelas à foliação geral. São equigranulares, de granulação grossa (entre 1 e $6 \mathrm{~mm}$ com textura lepidogranoblástica, às vezes porfiroclástica. Em seção delgada, observam-se contatos lobados entre os cristais, extinção ondulante em grãos de quartzo e feldspato, além de extinção com padrão em tabuleiro de xadrez nos cristais de quartzo.

A unidade de xistos é marcada por uma estruturação fina, homogênea, sem bandamento composicional definido, constituída principalmente por muscovita e biotita. Em seção delgada, apresenta textura inequigranular, com matriz de granulação fina $(\mathrm{de} \sim 0,25 \mathrm{~mm}$ ) e porfiroblastos com cerca de 1,5 $\mathrm{mm}$, exibindo contato lobado entre os grãos recristalizados, bem como extinção ondulante nos grãos de quartzo e com padrão em tabuleiro de xadrez.

O biotita gnaisse é rico em quartzo e caracteriza-se por uma granulação média a grossa, foliação bem desenvolvida, porém com bandamento composicional discreto a ausente. Apresenta injeções graníticas e localmente a estrutura planar da rocha é realçada pela presença de boudins máficos estirados e achatados no plano da foliação. A estruturação geral associa-se, às vezes, com dobras apertadas com comprimento de onda decamétrico, paralelizadas à foliação.

Esse domínio é marcado principalmente por uma foliação de alto ângulo, com densidade máxima de pólos em $\mathrm{N} 58^{\circ} \mathrm{E} / 78^{\circ} \mathrm{SE}$, e lineação direcional, com máximo em N43E/06NE, como pode ser visto na figura 3a e b. Em geral, essa foliação está associada com zonas de cisalhamento dúcteis, localizadas, que conferem à rocha uma trama planar e linear bem desenvolvida.

Figura 3 - Projeções estereográficas relativas ao domínio estrutural I. a) diagrama de densidade de pólos para dados de foliação geral; b) o mesmo para lineação mineral e de estiramento; c a e) densidade de pólos para os três padrões de foliação identificados, sendo d e e subordinados; f) dados de lineações associadas à foliação do diagrama e. $\mathrm{DM}=$ densidade máxima e $\mathrm{n}=$ número de dados.

O elemento estrutural considerado para definir o primeiro domínio foi a lineação de estiramento e mineral, a qual permanece direcional em todo o domínio. Entretanto, a foliação que determina a estruturação principal do domínio (figura $3 \mathrm{c}$ - máximo em $\mathrm{N} 58^{\circ} \mathrm{E} / 78^{\circ} \mathrm{SE}$ ) contém intercalações com faixas estreitas que apresentam variações na atitude da foliação, como pode ser visto na figura $3 \mathrm{~d}$ e e. Essas variações são caracterizadas, em alguns locais, por uma diminuição no ângulo de mergulho (figura $3 \mathrm{~d}$ - máximo em $\mathrm{N} 54^{\circ} \mathrm{E} / 60^{\circ} \mathrm{SE}$, com ângulos de mergulho variando de $35^{\circ}$ a $75^{\circ}$ ), onde a trama linear é pouco desenvolvida.

Em outros locais, a variação da foliação é dada por uma rotação da sua direção para norte, sem afetar, no entanto, o caráter direcional da lineação (figura 3e e f - máximos em N34 ${ }^{\circ} \mathrm{E} / 84^{\circ} \mathrm{NW}$ e $\mathrm{N} 24^{\circ} \mathrm{E} / 30^{\circ} \mathrm{NE}$, respectivamente). Ambas as variações na atitude da foliação conferem uma relação espacial 
com a estrutura principal na forma de variação lateral, caracterizando uma foliação anastomosada, o que às vezes pode ser percebido em escala de afloramento.

Nesse domínio, observam-se, localmente, dobras de perfis apertados, com planos axiais e eixos paralelos à foliação e lineação mineral e de estiramento, respectivamente, além de boudins máficos estirados nas direção vertical (figura 4a).

Os indicadores cinemáticos do domínio, quando observados no plano horizontal, consistem em pares S-C de foliação, porfiroclastos assimétricos rotacionados do tipo $\delta$ (figura $4 \mathrm{~b}$ e c), que são compatíveis com movimentação destral.

Figura 4 - Dobra e indicadores cinemáticos descritos no domínio estrutural I. a) boudins máficos estirados segundo a foliação principal; b e c) indicadores cinemáticos relativos ao domínio estrutural I, observados no plano horizontal (pares S-C de foliação e porfiroclasto de feldspato rotacionado, respectivamente).

\section{Domínio estrutural II}

O domínio estrutural II consiste em um pequeno trecho da seção, composto essencialmente por quartzitos impuros de granulação grossa. Estas rochas apresentam na sua composição pequenas quantidades de feldspato e muscovita, os quais, juntamente com ribbons de quartzo, definem a estrutura da rocha. A noroeste, essas rochas mostram uma segregação com porções de composição gnáissica.

O elemento estrutural determinante desse domínio é a foliação com mergulho moderado para noroeste, com densidade máxima de pólos em $\mathrm{N} 54^{\circ} \mathrm{E} / 60^{\circ} \mathrm{NW}$ e mergulhos variáveis entre $30^{\circ}$ e $79^{\circ}$ (figura 5a). A lineação é predominantemente de mergulho (densidade máxima em $\mathrm{N} 289^{\circ} / 24^{\circ} \mathrm{NW}$ e secundária em $\mathrm{N} 348^{\circ} / 52^{\circ} \mathrm{NW}$ ), sendo definida por minerais micáceos orientados e grãos de quartzo estirados. Entretanto, essa lineação torna-se direcional ( $\mathrm{N} 41^{\circ} / 08^{\circ} \mathrm{NE}$ ) em direção a noroeste (figura 5 b). Não foram observados indicadores cinemáticos nesse domínio.

Figura 5 - Projeções estereográficas dos domínios estruturais II e III. a) Diagrama de densidade de pólos para os dados de foliação do domínio II; b) Diagrama de densidade da lineação de estiramento; c) Estereograma de freqüência para a foliação do domínio III; d) Estereograma de freqüência para as lineações do domínio III. DM = densidade máxima e $\mathrm{n}=$ número de dados.

\section{Domínio estrutural III}

Esse domínio é composto por granulitos félsicos em sua parte central e, nas bordas, (granada)-biotita gnaisses com anfibólio de composição tonalítica. Os granulitos são caracterizados por uma foliação milonítica bem pronunciada, sem bandamento composicional. Apresentam granulação seriada (entre 0,1 e 1 $\mathrm{mm}$ ), contato fortemente lobado entre os grãos, além de extinção ondulante e feldspatos geminados por deformação. A estruturação geral é definida pela orientação de minerais como ortopiroxênio, hornblenda e ribbons de quarzto, sendo que os primeiros se mostram bastante corroídos devido à reação de transformação para a hornblenda.

Os gnaisses desse domínio exibem também uma forte foliação milonítica, com bandamento composicional limitado, paralelo à foliação, e boudins máficos estirados na direção vertical. Em seção delgada, apresentam textura lepidogranoblástica porfiroclástica, granulação fina a média (entre 0,2 e $2 \mathrm{~mm}$ ), intercalação entre bandas milimétricas de ribbons de quartzo e feldspato e matriz de granulação mais fina, com contatos levemente poligonizados entre os grãos, além de pequenas bandas de deformação recristalizadas por "bulging".

O domínio estrutural III é individualizado por uma zona de cisalhamento vertical destral, relativamente espessa. Em projeção estereográfica, apresenta-se semelhante ao domínio I, com um máximo principal da foliação em $\mathrm{N} 54^{\circ} \mathrm{E} / 90^{\circ}$, e um máximo secundário em N16 ${ }^{\circ} \mathrm{E} / 76^{\circ} \mathrm{SE}$ (figura $5 \mathrm{c}$ ), restrito a sua extremidade norte. Esta variação da foliação está relacionada com a rotação da foliação e é responsável pela geometria anastomosada da estrutura. Entretanto, esse trecho não apresenta a variação lateral para uma foliação de ângulo de mergulho moderado, como ocorre no domínio I. Esta se apresenta apenas em relação de sobreposição com a principal, sendo a foliação de mais baixo caimento posterior (figura 6a).

Figura 6 - Sobreposição de foliações e indicador cinemático descritos no domínio estrutural III. a) foliação de caimento moderado para SE, sobreposta à foliação principal, vertical; b) indicador cinemático destral (porfiroclasto de feldspato fraturado, exibindo deslocamento sintético em relação ao movimento da foliação). 
A lineação mineral do domínio apresenta também orientação NE-SW e baixo caimento, resultando em uma orientação estatística em N235\% $/ 12^{\circ} \mathrm{SW}$ (figura 5d). A relação geométrica dessa estrutura com a foliação permite classificá-la como direcional. Os indicadores cinemáticos observados são restritos a porfiroclastos de feldspato fraturados (fraturas C') (figura 6b) e pares $\mathrm{S}-\mathrm{C}$ de foliação, ambos compatíveis com movimentação destral. No extremo norte desse domínio, foram observados indicadores cinemáticos (pares S-C de foliação) fora do plano perpendicular ao vetor vorticidade, ou seja, no plano YZ, que são compatíveis com bloco sudeste subindo em relação ao bloco noroeste.

\section{Domínio estrutural IV}

Este domínio é caracterizado pela presença do mesmo granulito félsico do domínio III, porém com bandamento composicional melhor definido, como resultado de uma maior variação na granulação, com porções de granulação dominantemente grossa e aspecto maciço.

O domínio caracteriza-se por uma foliação de mergulho baixo a moderado (figura 7a), mas nesse caso para $\mathrm{SE}\left(\mathrm{N} 53^{\circ} \mathrm{E} / 48^{\circ} \mathrm{SE}\right)$. A lineação possui baixo caimento para SW e apresenta-se direcional. Não foram observados indicadores cinemáticos nesse setor.

Figura 7 - Projeções estereográficas (polares e ciclográficas) dos domínios estruturais IV e V. a) Diagrama de densidade da foliação do domínio IV; b) Diagrama de densidade da lineação mineral do domínio IV; c) Densidade de pólos para dados de foliação do domínio V; d) Diagrama de freqüência para a lineação mineral; e) Geometria das dobras no domínio V. DM = densidade máxima e n = número de dados.

\section{Domínio estrutural V}

Esse domínio compreende uma associação de clinopiroxênio-anfibólio-biotita gnaisse e granulitos máficos. Os gnaisses têm aspecto maciço, com variação composicional dada por injeções que estão paralelizadas com a foliação e granulação fina a média. Em lâmina delgada observam-se ribbons de quartzo de até $3 \mathrm{~mm}$, contato levemente poligonizado entre os grãos e extinção ondulante com padrão em tabuleiro de xadrez.

Os granulitos, compostos basicamente por plagioclásio, ortopiroxênio, hornblenda e alguma biotita, apresentam granulação grossa e bandamento composicional pouco pronunciado. Essas rochas mostram um amplo desenvolvimento de microestruturas de alta temperatura como feições de recristalização por migração de borda de grãos, resultando em contatos fortemente interlobados entre os mesmos.

As projeções estereográficas relativas a esse domínio são mostradas na figura 7c, d e e. Nota-se que há uma maior dispersão nas atitudes da foliação, dispersão esta que pode ser relacionada tanto com rotação da mesma para norte (como já visto nos domínios anteriores), como pela presença de dobras métricas de perfis abertos, associadas principalmente às rochas granulíticas (figura 8a). O domínio apresenta eixos de dobras de baixo caimento na direção NE-SW e planos axiais de mergulho alto, também na direção NE-SW (figura 7e). Nas porções intermediárias aos granulitos, as dobras tornam-se isoclinais, de charneiras apertadas, com geometria semelhante às dobras abertas (figura 8b). A lineação mineral e de estiramento apresenta um máximo principal em $\mathrm{N} 13^{\circ} / 06^{\circ} \mathrm{NE}$, e um máximo secundário em $\mathrm{N} 50^{\circ} \mathrm{E} / 00^{\circ}$, ambos de caráter direcional, resultante da rotação observada na foliação (figura 7d).

De forma análoga aos domínios I e III, observa-se também neste trecho da seção uma relação de sobreposição entre as estruturas de alto ângulo e as estruturas de mergulho moderado para SE. Contudo, neste caso a foliação de alto ângulo é posterior (figura 8c).

Os indicadores cinemáticos encontrados (pares S-C de foliação, porfiroclastos rotacionados tipo $\delta$ ) (figuras $8 \mathrm{~d}$ e 8e) sugerem também movimentação destral.

Figura 8 - Fotografias de feições pertencentes ao domínio estrutural V. a) dobras abertas em afloramento de granulito máfico; b) dobras de perfis fechados em anfibólio-biotita gnaisse; c) sobreposição de foliações; d e e) indicadores cinemáticos (pares S-C e porfiroclasto de feldspato assimétrico rotacionado).

\section{DISCUSSÃO E CONCLUSÕES}

A seção estudada é caracterizada, de maneira geral, por uma zona verticalizada a SE, com movimentos direcionais, mostrando forte influência da zona de cisalhamento principal. Apesar da predominância de movimentos direcionais, as estruturas tipo boudins achatados na foliação e a geometria das dobras sugerem a existência de um encurtamento horizontal ortogonal ao plano de cisalhamento, com estiramento vertical subordinado. 
A parte central da seção é caracterizada por uma área de mergulhos para NW, com lineação principal de mergulho (domínio estrutural II), uma zona de cisalhamento vertical destral composta principalmente por granulitos félsicos (domínio estrutural III), e, a NW, uma zona de mergulhos moderado a baixo para SE (domínio estrutural IV). Apesar da ausência de indicadores cinemáticos relativos aos domínios II e IV, sugere-se que a interação entre esses três domínios caracterize uma extrusão local, respectivamente, com movimentos inversos e direcionais, uma vez consideradas as lineações mineral e de estiramento dos domínios II e IV.

Essa zona de extrusão acha-se vinculada a uma zona de cisalhamento vertical destral situada no centro da estrutura. A variação na lineação de estiramento no domínio II, que se torna uma lineação direcional na área mais próxima à zona de cisalhamento central, mostra uma influência dessa zona de cisalhamento mesmo em setores onde o mergulho da foliação é mais baixo.

A presença de indicadores cinemáticos no extremo norte do domínio III, observados fora do plano perpendicular ao vetor de rotação principal, que indicam elevação do bloco SE, corroboram a sugestão de extrusão local. Além disso, essas estruturas apontam também para a existência de um componente de encurtamento horizontal na região (Jiang et al. 2001).

No extremo norte da seção voltam a predominar as estruturas de alto ângulo com movimentos direcionais, porém, neste setor, sofrem uma maior influência de dobras abertas nas rochas granulíticas. Nos gnaisses do domínio $\mathrm{V}$, essas dobras registram uma amplificação cinemática vertical, acompanhada da diminuição progressiva do ângulo entre os flancos com as proximidades das zonas de cisalhamento locais registradas no domínio.

Dentro dos domínios marcados por estruturas predominantemente verticais, ocorre uma variação lateral de estruturas de mais baixo ângulo de mergulho para SE. Segundo o modelo polifásico de deformação para a área, estas estruturas estariam associadas às fases D1 + D2, responsáveis por empurrões para NW, seguidos por uma fase D3 que gerou as estruturas transcorrentes de alto ângulo (Machado 1983 e 1984, Heilbron 1993, Heilbron et al. 1995 e 1998). Entretanto, as relações de sobreposição entre essas estruturas e as verticais são marcadas por uma inversão de nucleação entre elas, ou seja, as estruturas de baixo ângulo se sobrepõem às de alto ângulo e vice-versa. Essa relação sugere que estas estruturas foram desenvolvidas concomitantemente, refletindo a predominância de cisalhamento puro e cisalhamento simples, respectivamente, relacionada à partição espacial e temporal da deformação (Tikoff \& Teyssier 1994).

De maneira semelhante, os dados apresentados descrevem uma extrusão localizada que contempla movimentos de massa acomodados por deslocamentos ortogonais a paralelos ao trend orogênico (extrusão lateral/frontal). Essa relação sugere uma deformação em regime transpressivo dominada por cisalhamento puro triaxial (base do triângulo de deformação da figura 2 de Jones et al, 1997), onde a extrusão se desenvolveu anteriormente, seguida pela atuação do componente de cisalhamento simples subordinado, responsável pela formação das estruturas verticais em seu interior.

Considerando-se o exposto, apesar da ausência de investigações geocronológicas relativas à seção estudada, os dados apresentados são compatíveis com uma deformação em regime transpressivo destral nãoconfinado, de forma similar ao proposto por outros autores (Correa Neto et al. 1993, Ebert et al. $1991 \mathrm{e}$ 1993a, Ebert \& Hasui 1998, Ebert 2005, Dehler 2002, Dehler \& Machado 2002, entre outros).

A seção estudada corresponde, lateralmente, a aba norte da divergência estrutural associada à Zona de Cisalhamento do Rio Paraíba do Sul. No entanto, neste segmento, a referida zona de cisalhamento apresenta uma menor influência nos seus setores adjacentes do observado em regiões mais a norte do Estado do Rio de Janeiro (Vicente et al. 2007, Karniol et al. 2007, 2008), resultando em estruturas mais independentes da zona de cisalhamento central e um padrão divergente menos pronunciado.

\section{Agradecimentos}

Os autores agradecem ao Conselho Nacional de Desenvolvimento Científico e Tecnológico (CNPq), pela concessão de uma bolsa de mestrado a Letícia Constantino Vicente, uma bolsa de doutorado a Tiago da Rocha Karniol e de uma bolsa de Produtividade em Pesquisa a Rômulo Machado (Proc. 300423/82-9).

\section{Referências bibliográficas}

Almeida F.F.M., Brito-Neves B.B., Carneiro C.D.R. 2000. The origin and evolution of the South American Platform. Earth-Science Reviews, 50:77-111.

Almeida F.F.M. \& Hasui Y. (Eds.) 1984. O Pré-Cambriano do Brasil. Edgard Blucher, São Paulo, 378 pp.

Almeida F.F.M., Hasui Y., Brito-Neves B.B., Fuck R.A. 1977. Províncias Estruturais Brasileiras. In: SBG, Simpósio de Geologia do Nordeste, 8, Atas, 363-391.

Almeida F.F.M., Hasui Y., Carneiro C.D.R. 1975. O Lineamento de Além Paraíba. Anais da Academia Brasileira de Ciências, 48(suplemento):575. 
Almeida J.C.H. 2000. Zonas de cisalhamento dúctil de alto grau do Médio Vale do Rio Paraíba do Sul. Tese de Doutoramento, Instituto de Geociências e Ciências Exatas, Universidade Estadual Paulista, 190 pp.

Campanha G.A.C. 1980. O Lineamento de Além Paraíba na área de Três Rios (RJ). Dissertação de Mestrado, Instituto de Geociências, Universidade de São Paulo, 99 pp.

Campanha G.A.C. 1981. O Lineamento de Além Paraíba na área de Três Rios - RJ. Revista Brasileira de Geociências, 11:159-171.

Correa Neto A.V., Dayan H., Valença J.G., Cabral A.R. 1993. Geologia e estrutura da zona de cisalhamento do Rio Paraíba do Sul entre Três Rios - RJ e Sapucaia - RJ. In: SBG, Simpósio de Geologia do Sudeste, 3, Atas, 194-200.

Dayan H. \& Keller J.V.A. 1990. A Zona de Cisalhamento do Rio Paraíba do Sul nas vizinhanças de Três Rios (RJ): uma análise da deformação dada por algumas feições estruturais. Revista Brasileira de Geociências, 19(4):494-506.

Dehler N.M. 2002. Extrusão tectônica oblíqua em regime transpressivo no Cinturão Paraibides, RJ. Tese de Doutoramento, Instituto de Geociências, Universidade de São Paulo, 161 pp.

Dehler N.M. \& Machado R. 2002. Geometria e cinemática da aba sul da estrutura divergente do Rio Paraíba do Sul ao longo da seção Areal - Três Rios, Rio de Janeiro. Revista Brasileira de Geociências, 32(4):481-490.

Dehler, N.M., Machado, R., Dehler, H., McReath, I., Nummer, A. R. 2006. Kinematics and geometry of structures in the southern limb of the Paraíba do Sul divergent structural fan, SE Brazil: a true transtentional shear. Anais da Academia Brasileira de Ciências, 17(2):1-17.

Dutton B.J. 1997. Finite strains in transpression zones with no boundary slip. Journal of Structural Geology, 19(9):1189-1200.

Ebert H. 1968. Ocorrências de fácies granulíticas no sul de Minas Gerais e em áreas adjacentes em dependência da estrutura orogênica: hipóteses sobre sua origem. Anais da Academia Brasileira de Ciências, 40(suplemento):215-229.

Ebert H.D. 2005. Estruturação tectônica e arcabouço crustal da região de interseção entre os cinturões Ribeira e Brasília: integração de dados geológicos, estruturais, geofísicos, geocronológicos e fisiográficos através de geoprocessamento e modelagem tridimensional. Tese de Livre-Docência, Instituto de Geociências e Ciências Exatas, Universidade Estadual Paulista, 236 pp.

Ebert H.D. \& Hasui Y. 1998. Transpressional tectonics and strain partitioning during oblique colision between three plates in the Precambrian of southeast Brazil. In: R.E. Holdsworth, R.A. Strachan, J.F. Dewey (eds.) Continental transpressional and transtensional tectonics. Geological Society, Special Publication, London, 135, pp.: 231-252.

Ebert H.D., Hasui Y., Costa J.B.S. 1991. O caráter transpressivo do Cinturão Transcorrente do Rio Paraíba do Sul. In: Simpósio Nacional de Estudos Tectônicos, 3, Boletim, 139-141.

Ebert H.D., Hasui Y., Sartorato G., Almeida S.H., Costa J.B.S. 1993. Arcabouço estrutural e tectônica transpressiva das faixas móveis da borda sul e sudeste do Cráton do São Francisco e da Sintaxe de Guaxupé. In: SBG Núcleo MG, Simpósio Nacional de Estudos Tectônicos, 4, Anais, 166-171.

Ebert H.D., Neves M.A., Hasui Y., Lopes J.A., Guerra M. 1995. Compartimentação crustal e evolução cinemática da Província Mantiqueira através da modelagem física. In: SBG, Simpósio Nacional de Estudos Tectônicos, 5, Boletim de Resumos Expandidos, 26-28.

Ebert H.D., Neves M.A., Hasui Y., Szatmari P., Aires J.R. 1993. Evolução dos cinturões de cisalhamento entre os blocos São Paulo, Vitória e Brasília através da tectônica colisional oblíqua - uma modelagem física. In: SBG, Simpósio Nacional de Estudos Tectônicos, 4, Anais, 254-258.

Egydio-Silva M. 1996. Zona de cisalhamento de alta temperatura - O Lineamento de Além Paraíba (RJ). Tese de Livre-Docência, Instituto de Geociências, Universidade de São Paulo, 226 pp.

Egydio-Silva M. \& Mainprice D. 1999. Determination of stress directions from plagioclase fabrics in high grade deformed rocks (Além-Paraíba shear zone, Ribeira fold belt, southeastern Brazil). Journ. Struc. Geol., 21: 1751-1771.

Egydio-Silva M., Vauchez A., Raposo M.I.B., Bascou J., Uhlein A. 2005. Deformation regime variations in an arcuate transpressional orogen (Ribeira belt, SE Brazil) imaged by anisotropy of magnetic susceptibility in granulites. Journal of Structural Geology, 27:1750-1764.

Fossen H., Tikoff B., Teyssier C. 1994. Strain modeling of transpressional and transtensional deformation. Norsk Geologisk Tidsskrift, 74:134-145.

Heilbron M. 1993. Evolução tectono-metamórfica da seção Bom Jardim de Minas (MG) - Barra do Piraí (RJ). Setor central da Faixa Ribeira. Tese de Doutoramento, Instituto de Geociências, Universidade de São Paulo, 261 pp.

Heilbron M., Tupinambá M., Almeida J.C.H., Valeriano C.M., Valladares C.S., Duarte B.P. 1998. New constraints on the tectonic organization and structural styles related to the Brasiliano Collage of the central segment of Ribeira Belt, SE Brazil. In: International Conference on Basement Tectonics, 14, 15-17.

Heilbron M., Valeriano C.M., Almeida J.C.H., Tupinambá M. 1991. A Megassinformal do Paraíba do Sul e sua implicação na compartimentação tectônica do setor central da Faixa Ribeira. In: SBG, Simpósio de Geologia do Sudeste, 2, Atas, 519527.

Heilbron M., Valeriano C.M., Valladares C.S., Machado N. 1995. A Orogênese Brasiliana no segmento central da Faixa Ribeira, Brasil. Revista Brasileira de Geociências, 25(4):249-266.

Hobbs B.E., Means W.D., Williams P. F. 1976. An outline of structural geology. John Wiley \& Sons, New York, 571 p.

Jiang D., Lin L., Williams P.F. 2001. Deformation path in high-strain zones, with reference to slip partitioning in transpressional plate-boundary regions. Journal of Structural Geology, 23(6-7):991-1005.

Jones R.R., Holdsworth R.E., Bailey W. 1997. Lateral extrusion in transpression zones: the importance of boundary conditions. Journal of Structural Geology, 19(9):1201-1217.

Karniol, T.R., Machado, R., Dehler, N.M. 2008. Transpressive dextral shear in the Italva-Itaperuna section, Northern State of Rio de Janeiro, Brazil (em revisão). Anais da Academia Brasileira de Ciências, 80: 1-18.

Karniol T.R., Machado R., Vicente L.C. 2007. Tectônica extensional no Cinturão Paraíba do Sul no noroeste do Rio de Janeiro: análise estrutural na seção Itaperuna (RJ) - Muriaé (MG). Revista Brasileira de Geociências, 37(3):625-636..

Machado R. 1983. Considerações sobre a estruturação tectônica divergente da porção ocidental do Estado do Rio de Janeiro. In: SBG, Simpósio Regional de Geologia, 4, Atas, 135-146.

Machado R. 1984. Evolução geológica e análise estrutural da região de Vassouras e Paracambi, porção ocidental do Estado do Rio de Janeiro. Tese de Doutoramento, Instituto de Geociências, Universidade de São Paulo, 196 pp. 
Machado R. \& Endo I. 1993. Cinturão de Cisalhamento Atlântico: um exemplo de tectônica transpressional neoproterozóica. In: SBG Núcleo MG, Simpósio Nacional de Estudos Tectônicos, 4, Anais, 189-191.

Machado R. \& Endo I. 1993. A megaestrutura em flor positiva do Vale do Rio Paraíba do Sul no Rio de Janeiro e suas implicações tectônicas regionais. In: SBG, Simpósio de Geologia do Sudeste, 3, Atas, 208-213.

Petternel R., Trouw R.A.J., Schmitt R.S. 2005. Interferência entre duas faixas móveis neoproterozóicas: o caso das faixas Brasília e Ribeira no sudeste do Brasil. Revista Brasileira de Geociências, 35(3):297-310.

Robin P.-Y.F. \& Cruden A.R. 1994. Strain and vorticity patterns in ideally ductile transpression zones. Journal of Structural Geology, 16(4):447-466.

Rosier G.F. 1957. A geologia da Serra do Mar entre os picos da Maria Comprida e do Desengano. Boletim da Divisão de Geologia e Mineralogia, $166 \mathrm{p}$.

Rosier G.F. 1965. Pesquisas geológicas na parte oriental do Estado do Rio de Janeiro. Boletim da Divisão de Geologia e Mineralogia, $222 \mathrm{p}$.

Sadowski G.R. 1983. Sobre a geologia estrutural de cinturões de cisalhamento continentais. Tese de Livre-Docência, Instituto de Geociências, Universidade de São Paulo, 108 pp.

Sanderson D.J. \& Marchini W.R.D. 1984. Transpression. Journal of Structural Geology, 6(5):449-458.

Schobbenhaus C., Gonçalves J.H., Santos J.O.S., Abram M.B., Leão Neto R., Matos G.M.M., Vidotti R.M., Ramos M.A.B., Jesus J.D.A. 2004. Carta geológica do Brasil ao milionésimo, sistema de informações geográficas - SIG e 46 folhas na escala 1:1000000. CPRM, Brasília.

Tikoff B. \& Teyssier C. 1994. Strain modeling of displacement-field partitioning in transpressional orogens. Journal of Structural Geology, 16(11):1575-1588.

Turner F.J. \& Weiss L.E. (Eds.) 1968. Structural analysis of metamorphic tectonites. McGraw Hill, New York, 545 pp.

Vauchez A., Tommasi A., Egydio-Silva M. 1994. Self-indentattion of a heterogeneous continental litosphere. Geology, 22:967-970.

Vicente L.C., Dehler N.M., Machado R., Karniol T.R. 2007. Extrusão tectônica e transporte lateral de massa na porção central do cinturão Paraíba do Sul, seção Três Rios - Matias Barbosa (RJ/MG). Revista Brasileira de Geociências, 37(2):281-292. 


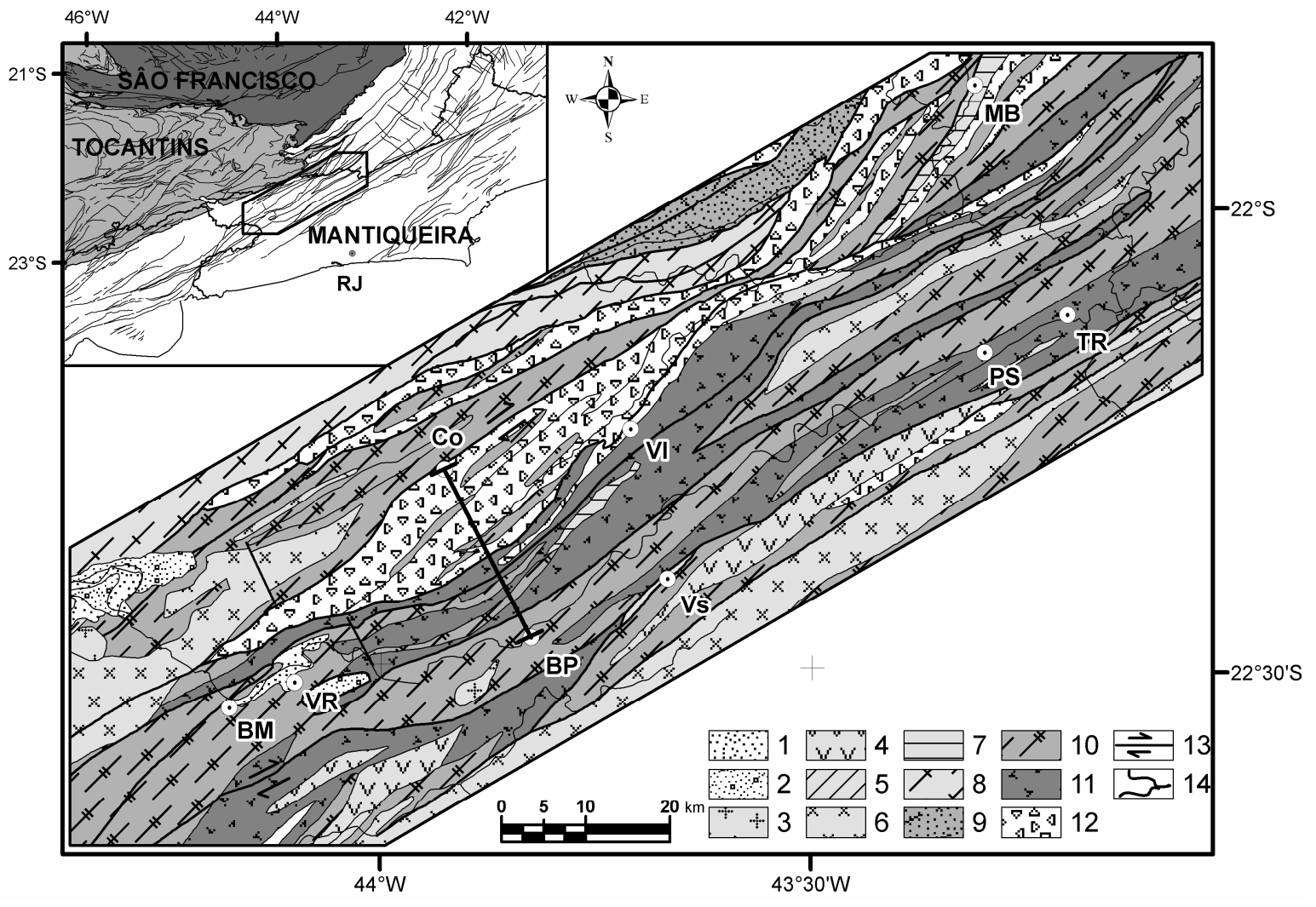

Figura 1

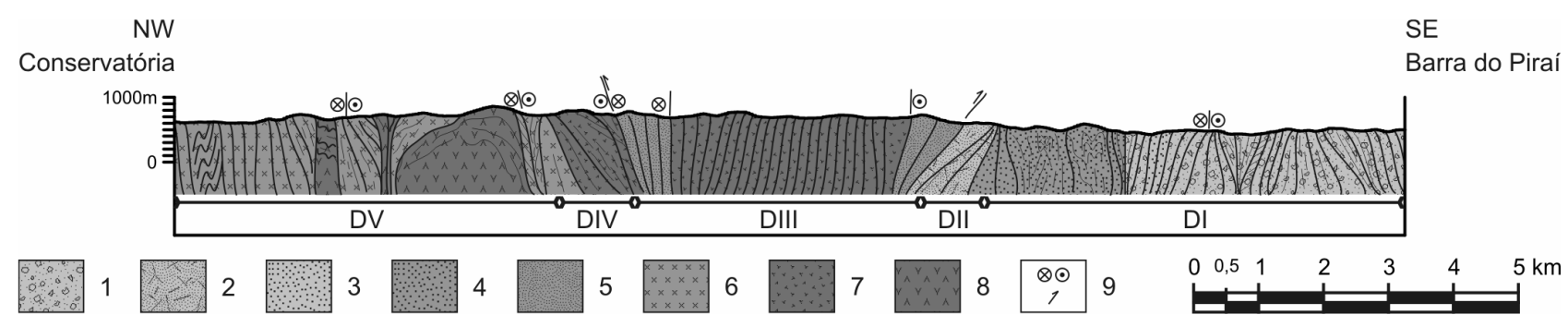

Figura 2 


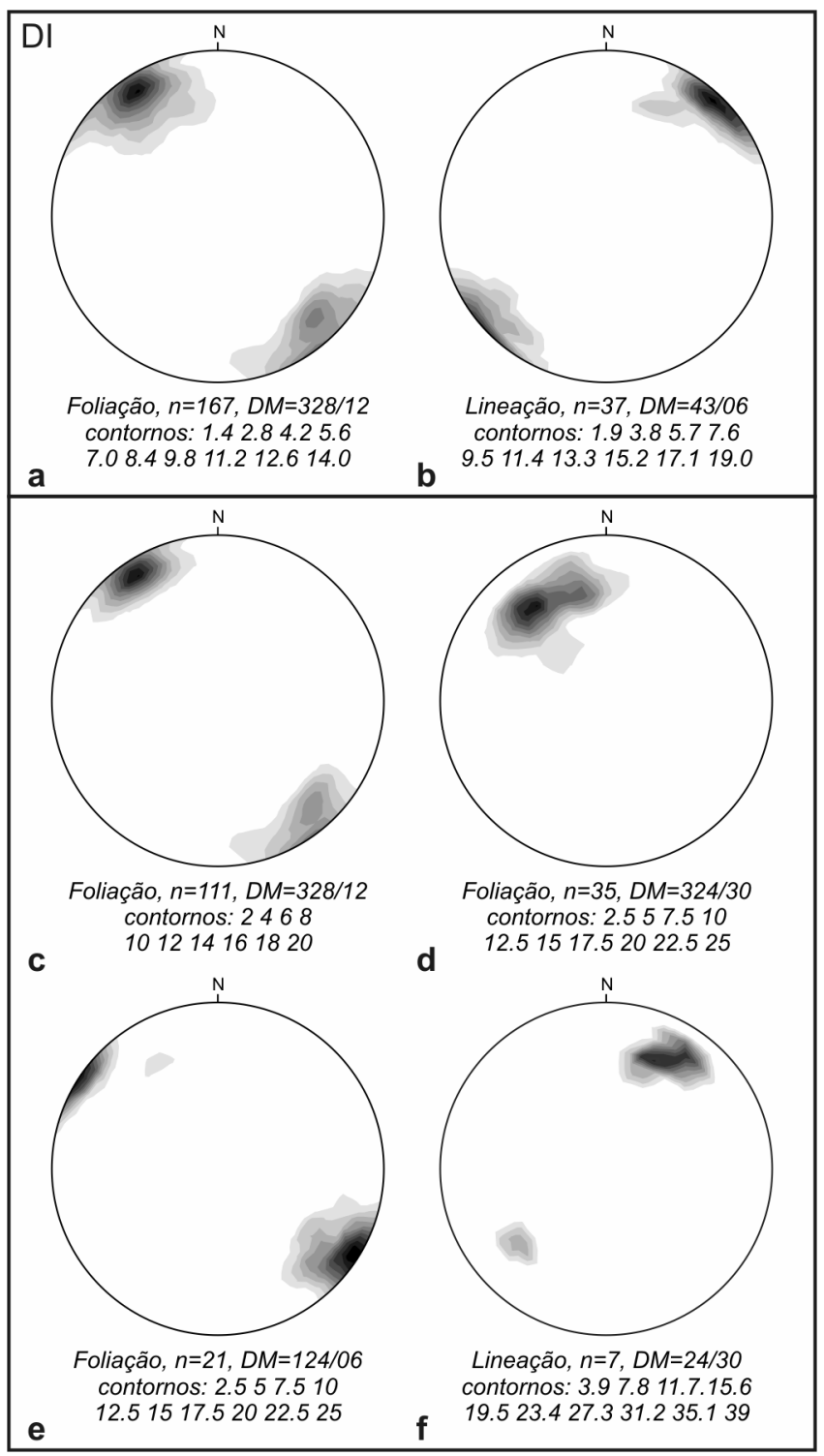

Figura 3 

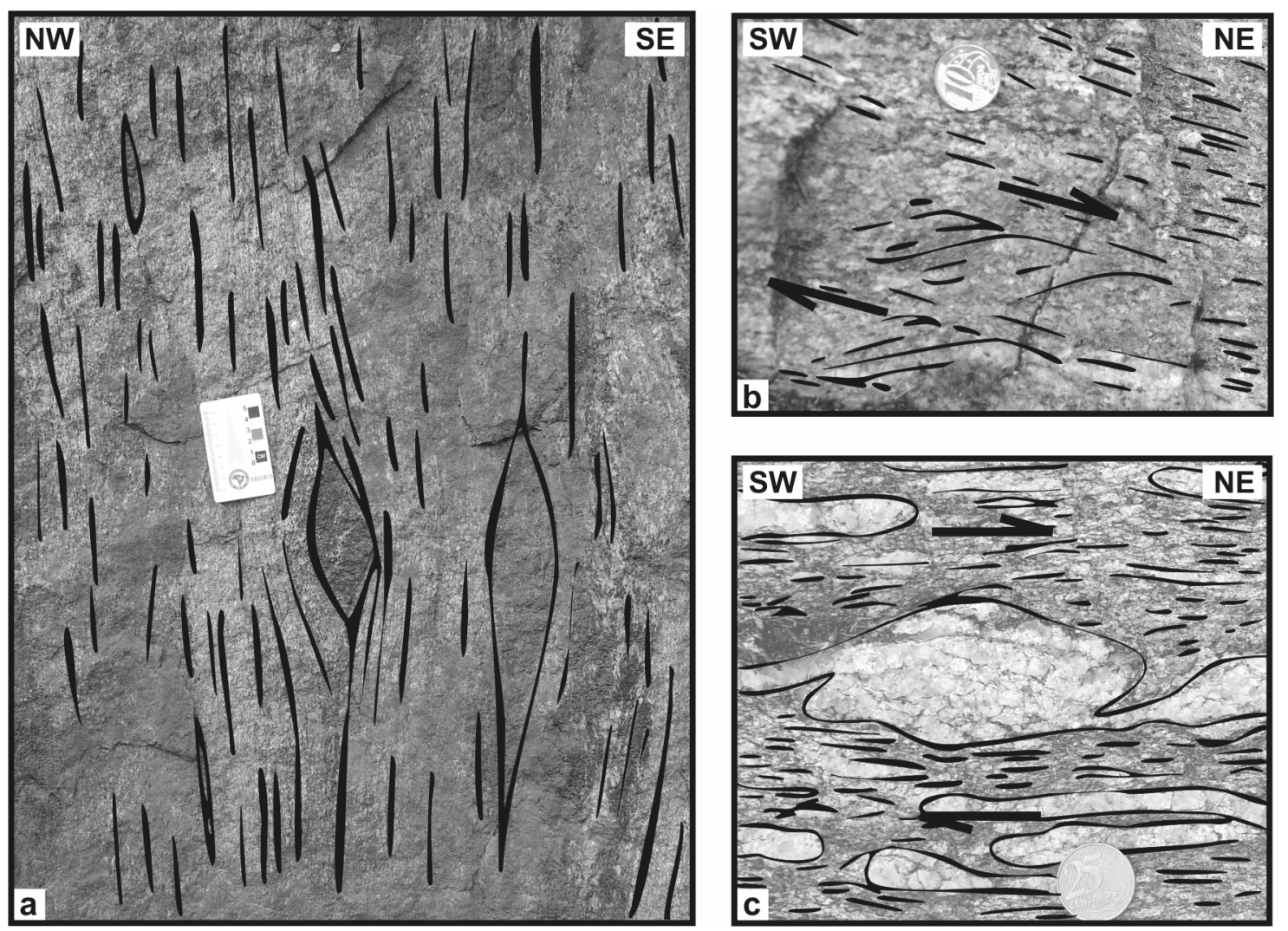

Figura 4

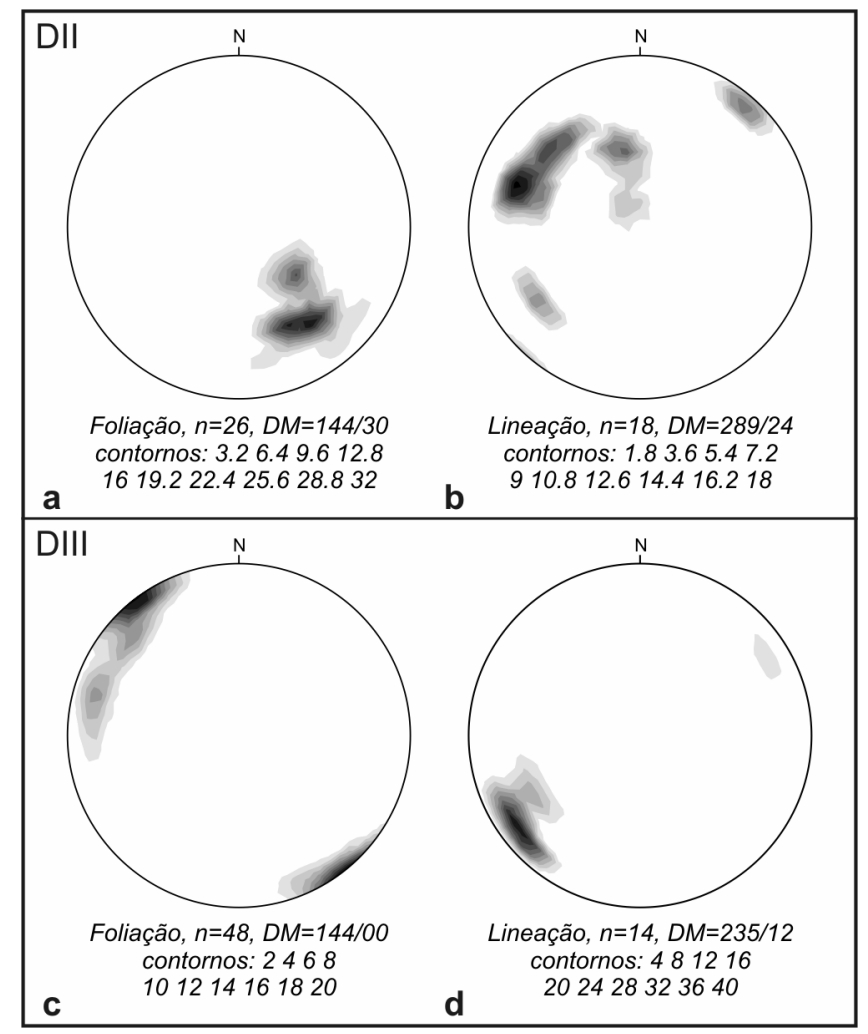

Figura 5 

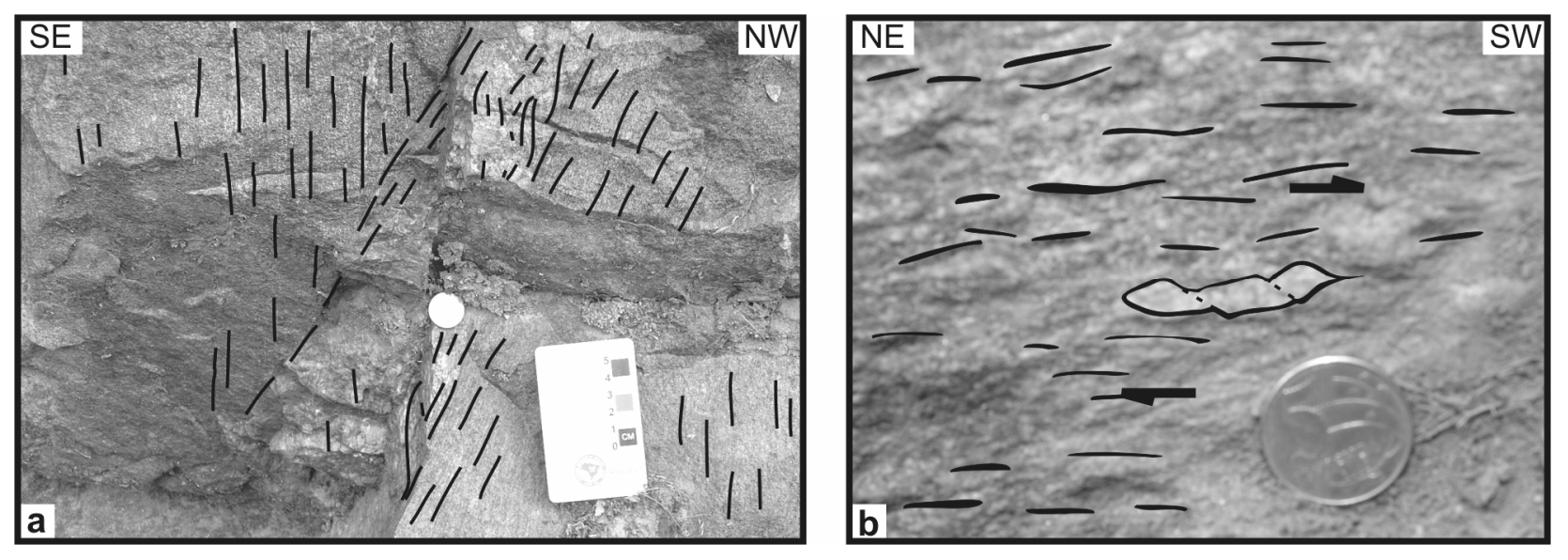

Figura 6

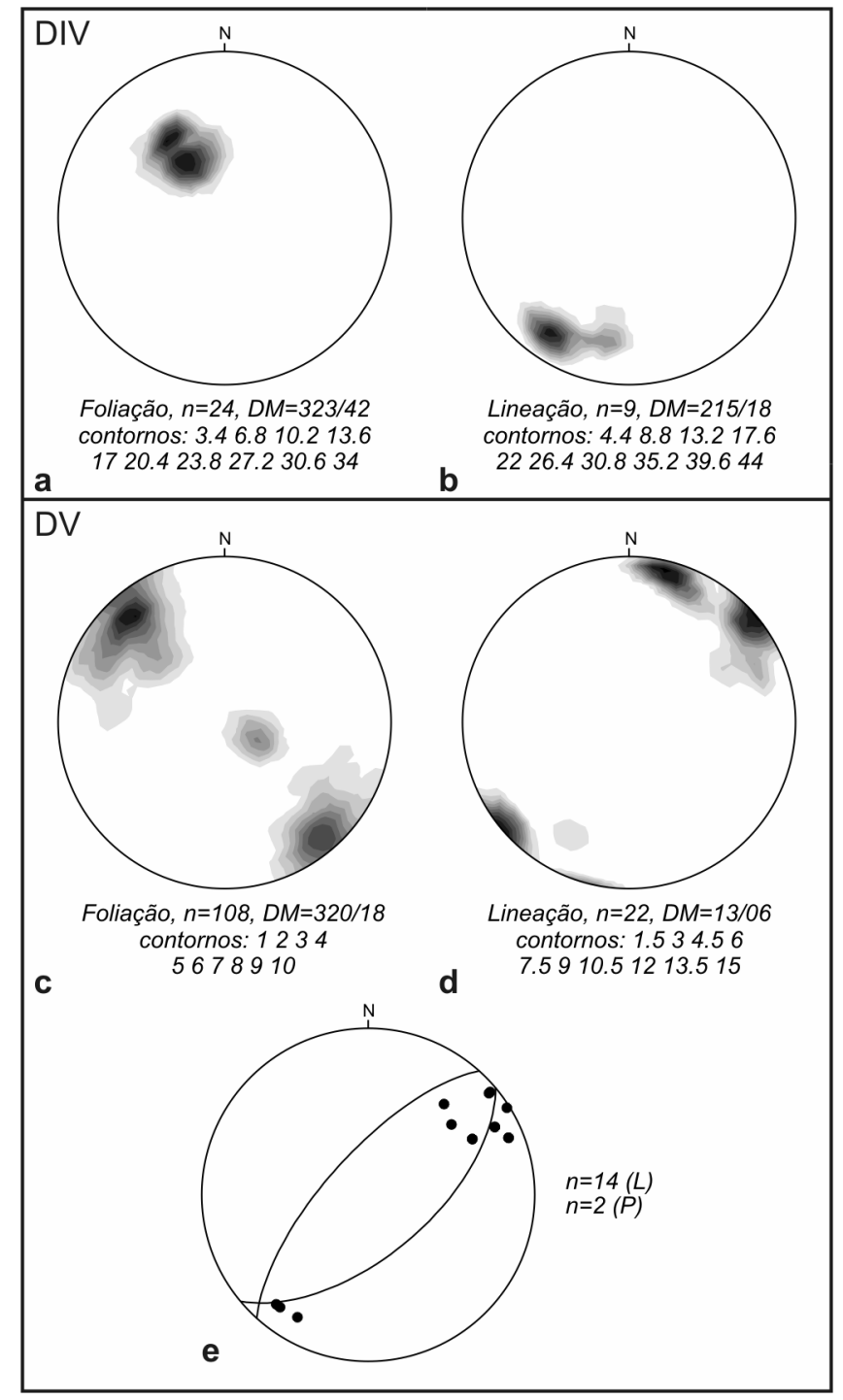

Figura 7 

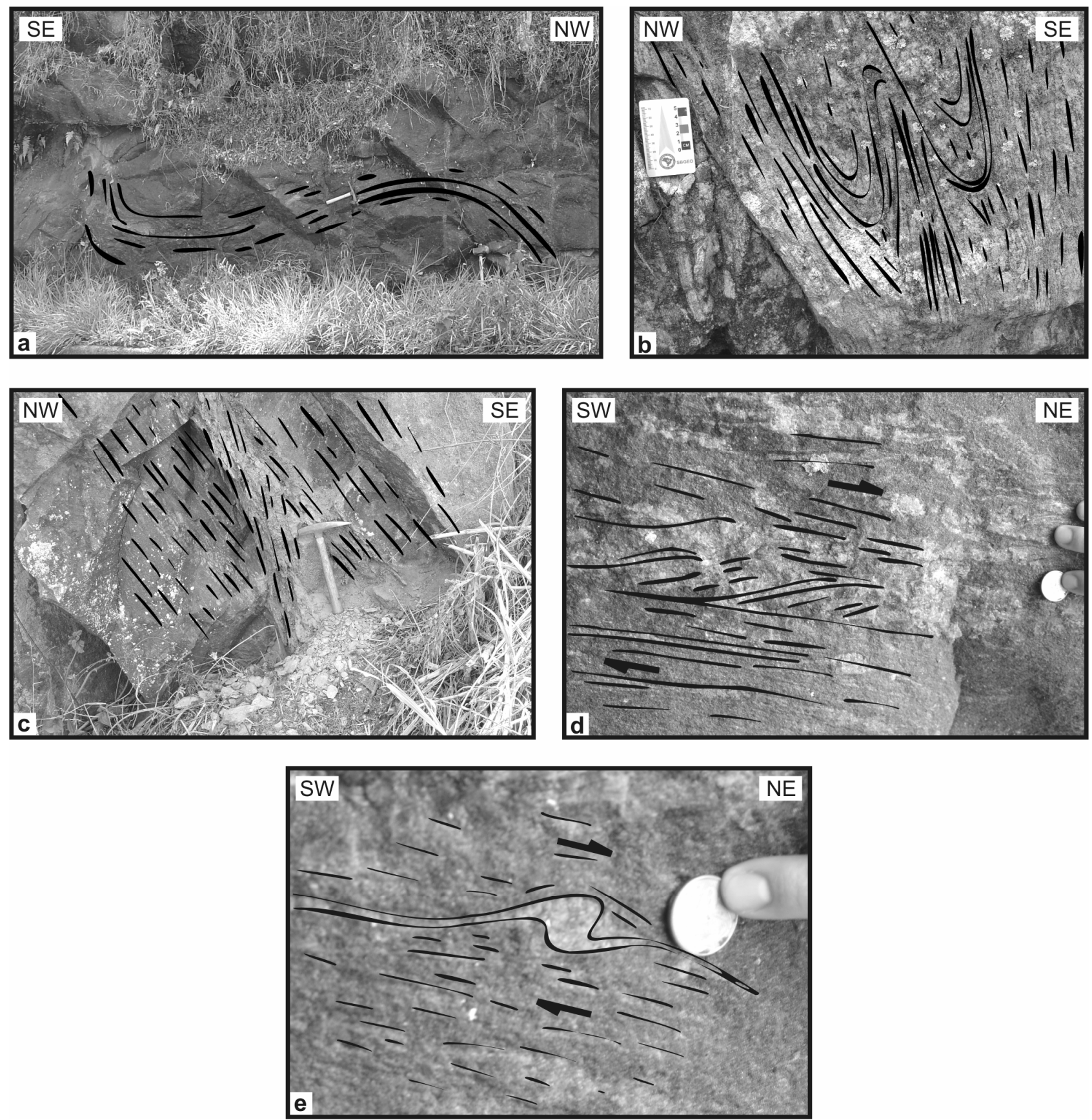

Figura 8 